\title{
Islam, Immigration, and Identity
}

\author{
Edited by \\ Todd Green
}

Printed Edition of the Special Issue Published in Religions 
Todd Green (Ed.)

\section{Islam, Immigration, and Identity}


This book is a reprint of the special issue that appeared in the online open access journal Religions (ISSN 2077-1444) in 2013 (available at:

http://www.mdpi.com/journal/religions/special_issues/islam).

Guest Editor

Todd Green

Department of Religion, Luther College

Decorah, IA 52101, USA

Editorial Office

MDPI AG

Klybeckstrasse 64

Basel, Switzerland

Publisher

Shu-Kun Lin

Managing Editor

Jeremiah R. Zhang

\section{Edition 2014}

MDPI • Basel $・$ Beijing

ISBN 978-3-906980-60-7

(C) 2014 by the authors; licensee MDPI, Basel, Switzerland. All articles in this volume are Open Access distributed under the Creative Commons Attribution 3.0 license (http://creativecommons.org/licenses/by/3.0/), which allows users to download, copy and build upon published articles even for commercial purposes, as long as the author and publisher are properly credited, which ensures maximum dissemination and a wider impact of our publications. However, the dissemination and distribution of copies of this book as a whole is restricted to MDPI, Basel, Switzerland. 


\section{Table of Contents}

List of Contributors

Todd H. Green

Preface Guest Editor $\mathrm{X}$

Todd H. Green

Islam, Immigration, and Identity: An Introduction 1

\section{Ariel Salzmann}

Migrants in Chains: On the Enslavement of Muslims in Renaissance and Enlightenment Europe Religions 2013, 4(3), 391-411 3 http://www.mdpi.com/2077-1444/4/3/391

\section{David A. Shefferman}

Rhetorical Conflicts: Civilizational Discourse and the Contested Patrimonies of Spain's Festival of Moors and Christians

Religions 2014, 5(1), 126-156 .24

http://www.mdpi.com/2077-1444/5/1/126

\section{Stephen H. Jones}

New Labour and the Re-making of British Islam: The Case of the Radical Middle Way and the 'Reclamation' of the Classical Islamic Tradition

Religions 2013, 4(4), 550-566 .55

http://www.mdpi.com/2077-1444/4/4/550

\section{Eren Tatari and Ahmet Yükleyen}

Minority Political Representation: Muslim Councilors in Newham and Hackney Religions 2013, 4(4), 502-528

http://www.mdpi.com/2077-1444/4/4/502

\section{Mahfoud Amara}

Sport, Islam, and Muslims in Europe: In Between or on the Margin?

Religions 2013, 4(4), 644-656

http://www.mdpi.com/2077-1444/4/4/644

\section{Anne Sofie Roald}

Majority versus Minority: 'Governmentality' and Muslims in Sweden

Religions 2013, 4(1), 116-131

http://www.mdpi.com/2077-1444/4/1/116

\section{Alfredo Alietti and Dario Padovan}

Religious Racism: Islamophobia and Antisemitism in Italian Society

Religions 2013, 4(4), 584-602 
Baljit Nagra and Ito Peng

Has Multiculturalism Really Failed? A Canadian Muslim Perspective

Religions 2013, 4(4), 603-620

http://www.mdpi.com/2077-1444/4/4/603

\section{Jennifer A. Selby}

Promoting the Everyday: Pro-Sharia Advocacy and Public Relations in Ontario, Canada's 'Sharia Debate'

Religions 2013, 4(3), 423-442

http://www.mdpi.com/2077-1444/4/3/423

\section{Louise Cainkar}

Learning To Be Muslim - Transnationally

Religions 2014, 5(3), 594-622

http://www.mdpi.com/2077-1444/5/3/594

Yvonne Yazbeck Haddad and Nazir Nader Harb

Post-9/11: Making Islam an American Religion

Religions 2014, 5(2), 477-501

http://www.mdpi.com/2077-1444/5/2/477

\section{Meena Sharify-Funk}

Pervasive Anxiety about Islam: A Critical Reading of 'Clash' Literature Religions 2013, 4(4), 443-468

http://www.mdpi.com/2077-1444/4/4/443 


\section{List of Contributors}

Alfredo Alietti is Senior Researcher in Urban Sociology at the University of Ferrara. He holds a $\mathrm{PhD}$ in sociology from the University of Milan. His research interests focus on topics at the national and European levels and include racism, anti-Semitism, Islamophobia, interethnic relations in urban settings, settlement processes of migrants, and ethnic segregation. He is a member of steering committee of international research network called Urban Advanced Marginality. He is also a member of the Esa Research Network 31 on Ethnic Relations, Racism, and Antisemitism, and he serves on the International Advisory Board for the Theomai Journal.

Mahfoud Amara is Lecturer in Sport Policy and Management and the Deputy Director of the Centre for Olympic Studies and Research, School of Sport, Exercise and Health Sciences, Loughborough University. His principal research area is comparative sports policy. He has a specific interest in sport in Arab and Muslim contexts. He has published material on the politics of the Pan-Arab Games, sport in colonial and postcolonial Algeria, sport and media in the Arab world, sport and modernization debate in the Gulf region, and sport development and development through sport in the Arab World. He also has research interests in sport, multiculturalism, and intercultural dialogue. He is the author of Sport, Politics, and Society in the Arab World (Palgrave Macmillan 2013).

Louise Cainkar is Associate Professor of Sociology at Marquette University. Her research interests include Arab American studies, Muslims in the United States, and migration and immigrant integration. She is the author of Homeland Insecurity: The Arab and Muslim American Experience after 9/11 (Russell Sage Foundation 2009). She is also the past recipient of the prestigious Carnegie Scholar Award for her work on the reinvigoration of Islamic practices among second generation Muslim Americans.

Todd Green is Assistant Professor of Religion at Luther College, where he teaches courses on European and American religious history. He writes and conducts research on Islamophobia and secularization in modern Europe. His peer-reviewed articles have appeared in publications such as the Journal of Church and State, Journal of 
Religion in Europe, Religion Compass, and CrossCurrents. He is the author of Responding to Secularization: The Deaconess Movement in Nineteenth-Century Sweden (Brill 2011). His most recent book project surveys the history and contemporary manifestations of Islamophobia in Europe and North America and will be published by Fortress Press in 2015 .

Yvonne Haddad is Professor of History of Islam and Christian-Muslim Relations at Georgetown University. She is the past president of the Middle East Studies Association and has served as vice president of the American Academy of Religion, New England Region as well as the vice president of American-Arab University Graduates. She is a recipient of the Distinguished Alumnus Award for Outstanding Achievement and Distinction in Service to the Profession, Boston University, School of Theology (2007) and Scholar of the Year: Canadian Corporation for Studies in Religion (2002). She is a member of the Council on Foreign Relations. Her extensive publications include Becoming American? The Forging of Arab and Muslim Identity in Pluralist America (Baylor University Press 2011); Muslim Women in America: The Challenge of Islamic Identity Today (Oxford University Press 2006); and The Islamic Understanding of Death and Resurrection (Oxford University Press 2002).

Nazir Harb is a doctoral student in Arabic and Islamic Studies at Georgetown University with foci in multimodal interaction and political discourse analysis in the field of linguistics. His dissertation focuses on forms of communicative interaction in the Arab Uprisings, and he conducts research more broadly on identity formation among American Muslims. He completed a master's degree in Arab Studies in Spring 2013 and has a master's degree in International Relations from Princeton University. His publications include articles on Muslims and Islam in America, a blog series on Princeton's 14 Points, and a co-authored chapter with Yvonne Haddad in Beyond 9/11: Transdisciplinary Perspectives on Twenty-First Century U.S. American Culture (Peter Lang 2013).

Stephen Jones is Research Associate at the Centre for Trust, Peace and Social Relations, University of Coventry. He completed his $\mathrm{PhD}$ on the Islamic tradition in 2010 and subsequently worked at the Centre for the Study of Ethnicity and Citizenship, University of Bristol, as a researcher on the ESRC/AHRC Religion and Society Programme project 'Muslim Participation in Contemporary Governance.' He 
is currently working on a project funded by the Templeton Foundation investigating the social and cultural drivers of contemporary debates about science and religion, based jointly at the University of Coventry and York University (Toronto).

Baljit Nagra is a postdoctoral research fellow at the Graduate School of International and Public Affairs at the University of Ottawa. She holds a PhD from the University of Toronto and has also previously held a postdoctoral fellowship funded by the Social Sciences of Humanities Research Council of Canada. Her research focuses on the social, political, and economic repercussions young Canadian Muslims have experienced since $9 / 11$.

Dario Padovan is Senior Researcher and Assistant Professor of Sociology in the Department of Culture, Politics and Society at the University of Turin. His research focuses on the history of social sciences, ethnic relations, racism, and social insecurity. He is a member of the Editorial Committee of Theomai Journal (Buenos Aires), and Cosmos and History (Melbourne). He is also a member of the Esa Research Network 31 on Ethnic Relations, Racism, and Antisemitism.

Ito Peng is Professor of Sociology and Public Policy at the Department of Sociology and the School of Public Policy and Governance, and the Director of the Centre for Global Social Policy at the University of Toronto. She teaches political sociology and comparative public policy, specializing in family and gender policies and comparative welfare states. She has written extensively on gender, labor market, and political economy of social policy reforms in East Asia. She is currently the Principal Investigator of the SSHRC funded international Partnership Research project called Gender, Migration and the Work of Care. The project examines how the reorganization of care influences government policies and global migration of care workers, and how migration in turn shapes public policies and global governance. She is a senior fellow at Massey College and Trinity College, University of Toronto; a senior fellow of Asia Pacific Foundation of Canada; and an associate researcher with the UNRISD.

Anne Sofie Roald is Professor in Religious Studies at Malmö University in Sweden. Her research interests include Islamist movements in the Middle East; Islam and gender in the Middle East and Europe; religious changes in Muslim minority 
communities; and minority-majority dynamics in Scandinavia. Her current research focuses on New Arab media and social changes. Roald publishes in English, Swedish, and Norwegian. In addition to many peer-reviewed articles, Roald has authored several books, including Women in Islam: The Western Experience (Routledge 2001); New Muslims in the European Context: The Experience of Scandinavian Converts (Brill 2004); and Religious Minorities in the Middle East: Domination, Selfempowerment, Accommodation (co-editor) (Brill 2011).

Ariel Salzmann teaches Islamic Studies, World History, and Cultural Studies at Queen's University in Canada. As one of the founding members of the Middle East and Islamic Studies Department of New York University, between 1997 and 2003 she promoted multi-regional and interdisciplinary approaches to the study of the Mediterranean and Asia. Past publications address state formation, fiscal sociology, economic history, identity formation, cartography, multi-religious urbanity, and Catholic-Muslim relations. The present study on the Mediterranean 'galley complex' forms part of a larger, comparative project on the historical sociology of religious and ethnic exclusion.

Jennifer Selby is Associate Professor of Religious Studies at Memorial University of Newfoundland. She has published articles in Culture and Religion and in Studies in Religion. She is the author of Questioning French Secularism: Gender Politics and Islam in a Parisian Suburb (Palgrave MacMillan 2012) and the co-editor (with Anna Korteweg) of Debating Sharia (University of Toronto Press 2012).

Meena Sharify-Funk is an Associate Professor for the Religion and Culture Department at Wilfrid Laurier University who specializes in Islamic studies with a focus on contemporary Muslim thought and identity. Sharify-Funk has written and presented a number of articles and papers on women and Islam, Islamic hermeneutics, and the role of cultural and religious factors in peacemaking. Her current book analyzes the impact of controversial issues that are shaping contemporary Muslim women in North America. Sharify-Funk's most recent book, Encountering the Transnational: Women, Islam, and the Politics of Interpretation, focused on the impact of transnational networking on Muslim women's identity, thought, and activism. She also has co-edited two books: Cultural Diversity and Islam (University Press of America 2003) and Contemporary Islam: Dynamic, Not Static (Routledge 
2006) and is currently a Series Editor for the Theology and Philosophy Series at Pickering and Chatto Publishers.

David Shefferman is Associate Professor of Religion and Culture at Manhattan College. His research explores widely the twentieth- and twenty-first century discourses about religion and includes studies of popular depictions of Afro-Cuban traditions in film, literature, music, news, and digital formats as well as analysis of media uses among practitioners. He is the editor, with Claudia Setzer, of The Bible and American Culture: A Sourcebook (Routledge 2011) as well as the author of a range of essays on religious tourism and public spectacle in the Caribbean, Spain, and the United States.

Eren Tatari is an Assistant Professor in the Department of Political Science at Rollins College. Her research and teaching interests include ethnic and religious minorities in the US and Western Europe and women in Islam. Her latest book is titled Surrendering to God: Understanding Islam in the Modern Age (Tughra Books 2012).

Ahmet Yükleyen is Croft Associate Professor of Anthropology and International Studies at the University of Mississippi. He studied international relations at Bilkent University in Turkey and completed his MA degree at the Graduate School of International Studies, University of Denver. He received his Ph.D. in Cultural Anthropology from Boston University in 2007. He is the author of Localizing Islam in Europe: Turkish Islamic Communities in Germany and the Netherlands (Syracuse University Press 2012). He was a senior resident fellow at the Woodrow Wilson International Center for Scholars for 2011-12. He served as a visiting scholar at Sabanci University's Conflict Analysis and Resolution program for 2013-14 with the support of TUBITAK. 


\section{Preface}

The editor-in-chief of Religions, Peter Kaufman, reached out to me in 2012 and offered me the opportunity to serve as the guest editor for a special issue dedicated to a topic of my choosing involving immigration and religion. I quickly settled on the theme of "Islam, Immigration, and Identity" for two reasons. First, my own research has focused on Muslim immigration in modern Europe, including the challenges posed to national and European identities in light of the increasing presence and visibility of Islam. A special issue that tackled these challenges but that did so in a broader geographical framework struck me as incredibly timely and necessary. Second, I anticipated that the special issue would come out in 2013, exactly twenty years after Samuel Huntington first published his famous article, "A Clash of Civilizations?" The influence of Huntington's article on Western political and public discourse concerning Islam and its relationship to the West cannot be underestimated, and so to mark the twentieth anniversary of Huntington's essay with an issue dedicated to reconsidering his thesis seemed appropriate.

All of the essays in this volume originally appeared in an online open access format. I am grateful that Peter Kaufman and MDPI showed interest in publishing these essays in a printed volume as well. The transition from an online to a traditional printed format has been smooth. The main difference involves the order of the essays. In the online issue, the essays were published in the order in which they were received and peer reviewed, whereas I have taken the liberty of organizing the essays for the book in a manner that reflects geographical and, to some extent, thematic connections. Some additional editing for syntax and structure has also taken place, but the basic content of each essay remains the same.

I am proud of the quality of the scholarship that readers will find in this volume, and I hope that the insights within these essays will provoke a deeper, more nuanced discussion concerning the place of Muslim minority communities in the West.

Todd H. Green

Guest Editor 


\section{Islam, Immigration, and Identity: An Introduction}

\section{Todd H. Green}

Reprinted from Religions. Cite as: Green, T.H. "Islam, Immigration, and Identity: An Introduction." Religions 5 (2014): 700-702.

It has been two decades since Samuel P. Huntington, a Harvard political scientist, first published his famous essay, "The Clash of Civilizations?" [1]. In the essay, and later in his book with the same title (minus the question mark) [2], Huntington argues that conflict in the post-Cold War era will be driven largely by irreconcilable cultural and religious differences, particularly in regards to Islam and the West. The conflict between these two civilizations, while not new, is bound to persist in large part because Islam is prone to violence. Much of the global conflict that exists in the modern world, observes Huntington, involves Muslims. It is for this reason that he states so bluntly: "Islam has bloody borders" ([1], p. 35).

The "clash of civilizations" thesis did not originate with Huntington. Bernard Lewis, the prominent historian of Islam and orientalist, had already invoked this language in his own scholarship, most notably in his 1990 article for The Atlantic Monthly, "The Roots of Muslim Rage" [3]. In the article, Lewis explores many possible explanations as to why Muslims have so much hatred for the West. He concludes that Muslims are jealous and humiliated due to the superiority of Western civilization. Western secularism and modernism in particular are the objects of Muslim anger and the reason behind the surge in Islamic fundamentalism in recent history.

Both Huntington and Lewis invoke the very themes that Edward Said describes as the foundation of Orientalism [4]. Both view the West as superior and enlightened, in contrast to the Muslim world (i.e., the Orient), which they portray as monolithic, violent, backwards, and irrational. Conflict is inevitable in light of such profound differences, insist Huntington and Lewis, and yet both scholars maintain that the real source of this conflict lies within Islam.

After the al-Qaeda attacks of September 11, 2001, the clash of civilizations thesis found ready acceptance on both sides of the Atlantic as politicians, foreign policy advisors, and even some high-profile academics utilized the thesis both as an explanation for those events and more broadly as justification for the global War on Terror. Politicians and journalists also applied the thesis to domestic tensions stemming from the growth in recent decades of Muslim minority communities in the West via migration and immigration. The clash of civilizations narrative has now become the primary framework within which public discourse concerning the presence of the Muslim 'Other' within Western nations takes place. Prominent conflicts from the past few decades, including the Rushdie Affair, the Danish cartoon controversy, and the Ground Zero Islamic Center debate, are frequently explained through this narrative and its underlying assumption that Muslim and Western identities cannot be reconciled.

In this Special Issue, distinguished scholars from Europe and North America, representing diverse disciplinary and methodological approaches, problematize the clash of civilizations narrative by exploring more deeply and richly the intersection of Islam, immigration, and identity 
in the West. The themes addressed in these articles represent some of the most debated issues among scholars, journalists, and politicians pertaining to the place of Muslims in the West and include multiculturalism, Muslim political representation, Sharia controversies, the reconciliation of Muslim with national identities, racism, gender and sexuality, and Islamophobia. Geographically, the authors address the intersection of Islam, immigration, and identity in Western countries that include Britain, France, Italy, Malta, Spain, Sweden, Canada, and the United States.

What the authors share in common is the desire to shed light on how the growth and increasing visibility of Muslim minority communities in the West has led both Muslim and non-Muslim populations to reflect on and/or reconsider cultural, religious, and national identities in light of the 'Other.' While the authors take seriously the very real tensions that exist between Muslim minority communities and the non-Muslim majorities of Europe and North America, they argue, explicitly or implicitly, that recourse to a clash of civilizations framework to explain these tensions does not do justice to the complex ways in which Muslim and Western identities are negotiated and transformed in light of the historic and contemporary interactions between the two.

I want to thank the journal's Editor-in-Chief, Peter Kaufman, and the journal's managing editor, Jerry Zhang, for their support and guidance in putting first the Special Issue and then the book together. I also want to thank the many peer reviewers who vetted the articles and gave constructive feedback to the authors in this volume. Finally, I want to thank the authors for accepting the invitation to contribute to this Issue. I believe their scholarship reflects important dimensions in the ongoing debates concerning the multifaceted relationship between Islam and the West.

\section{References and Notes}

1. Samuel P. Huntington. "The Clash of Civilizations?” Foreign Affairs 72 (1993): 22-49.

2. Samuel P. Huntington. The Clash of Civilizations and the Remaking of World Order. New York: Simon \& Schuster, 1996.

3. Bernard Lewis. "The Roots of Muslim Rage." The Atlantic Monthly, September 1990, 47-60.

4. Edward W. Said. Orientalism. New York: Vintage Books, 1978. 


\title{
Migrants in Chains: On the Enslavement of Muslims in Renaissance and Enlightenment Europe
}

\author{
Ariel Salzmann
}

\begin{abstract}
Between the Renaissance and the French Revolution, hundreds of thousands of Muslim men and women from the southern and eastern shores of the Mediterranean were forcibly transported to Western Europe. Those who were not ransomed or who did not return to their homelands as part of prisoner exchanges, languished for decades and, many, for the remainder of their lives, in chattel slavery. This essay considers the enslavement process overall and the conceptual frameworks necessary to bring this poorly known chapter in European social history into focus. Emphasizing the case of the Muslim galley slaves of the Catholic ports of France, Italy and Malta, it argues that without appreciating this phenomenon as a form of migration, as well as part of a larger history of global slavery, it not possible to understand the specificity of confessionalized enslavement within the early modern Mediterranean.
\end{abstract}

Reprinted from Religions. Cite as: Salzmann, A. "Migrants in Chains: On the Enslavement of Muslims in Renaissance and Enlightenment Europe.” Religions 4 (2013): 391-411.

\section{Introduction}

It was one of the curious incidents of her Grand Tour of Italy in 1770. Strolling along the quay of Genoa on St. Martin's Day, the English lady and her companions heard men from a docked ship calling out. Introducing themselves as "poor Christians who have entirely abandoned Mahomet," they invited the tourists to come aboard to listen to them play music. Their performance, she wrote a friend afterward, "was by no means bad." But the men's appearance elicited a mixture of horror and compassion. Their "poor legs, which were naked, almost black, and, of some, the flesh had partly grown over their fetters." Muslim slaves, chained to the oars, begged the lady and her friends for money and to "listen to the details of their calamitous situation." These hapless souls, she learned, were but a few of the 350 Muslim "prisoners" in the city. Most of the men were condemned to a life of toil as galley slaves. Muslim girls and women were given to wealthy matrons for work in the "most menial department of their household." ([1], vol. 1, pp. 308-09).

Passing comments in an epistolary exchange between an anonymous English traveler and a friend open a small window on a large, unacknowledged story. It is the history of hundreds of thousands of Muslim men and women who spent much of their adult lives in bondage in early modern Catholic Europe. ([2], pp. 34-35) Of course, the enslavement of Muslims was only part of a larger, forced exchange of persons who experienced captivity, were either ransomed or subjected 
to life-long servitude across the Muslim-Christian divide in the Mediterranean during these centuries. Numerous publications, popular, fictive and scholarly, recount the horrors of the "white" slavery of Christians in Muslim lands [3-5]. Yet, there has been decidedly less interest in hearing the stories of the Muslim victims. In fact, for more than a century there was little historical research on the subject ([2], pp. 1-13; [6]). When this past remains largely unknown even to historians and social scientists of European inter-religious relations and migration ([7], p. 13) (Compare [4,6]), it should not surprise us that there is no public awareness that the number of Africans, Mediterranean and Eastern European Muslims, Jews, and Orthodox Christians who languished in bondage in Western Europe greatly outnumbered the Catholics and Protestants enslaved in the contemporary Muslim world.

Archival research by historians on Muslim servitude in early modern Europe has begun to recover this past $[2,8-15]$. This essay does not pretend to add substantially new documentation to the reconstruction project. Rather, it seeks to reconsider scholarly approaches to the subject. To date, historians have treated the stories of Muslim men and women in Western Europe (as well as Protestants and Catholics held in North African and Ottoman captivity) almost exclusively from the perspectives of the historiography of slavery. Yet the Muslims of Enlightenment Genoa, whom our English traveler encountered, were both enslaved persons and forced migrants. As slaves, they suffered, in the formulation of Orlando Patterson, a form of "social death": a profound and brutal process of estrangement intended to deracinate them from home, kin, status and property [9]. However, the enslaved should also be regarded as part of a distinct flow of migrants [16]. This forced transfer of individuals from the Muslim shores of the Mediterranean accelerated just as the last indigenous Muslim communities were expelled from Portugal and Spain. Numbering in the hundreds of thousands over the centuries, Muslim men and women, some from as far east as Iran and as far west as Morocco, were, by virtue of circumstance and confession, forcibly resettled in kingdoms and city-states in the Catholic Mediterranean, from Spain to France, Italy and Malta. Segregated from the larger society on the basis of their faith, Muslim galley slaves forged their own communities with religious leadership, houses of worship, common languages of work and principles of solidarity. Approaching these isolated groups from the perspective of migration as well as from a history of global enslavement will contribute to a better understanding of the characteristics and dynamics of confessionalized captivity in the early modern world. It will also serve to remind us of the continuity of Muslim settlements in Europe, east and west, from the medieval period to the present. 


\section{The Global Crusade and Human Captivity}

Human migration bridged the inner sea between the regions now known as "Europe," the "Middle East" and "North Africa". It was both the consequence and expression of the high degree of mobility between shores, the shifting political boundaries of empires and the intensity of cross-cultural exchange. Before the modern period, few moral qualms impeded the trade in human beings. All three monotheistic religions condoned human slavery; all post-Roman polities sought to regulate it to suit cultural, economic and political ends. The strong elements of continuity in the history of enslavement within the Mediterranean basin (and the Black Sea region) notwithstanding, at the end of the medieval period important geopolitical ruptures changed the institution, the direction of population flows and the ethno-religious and gender composition of persons ensnared in its nets.

For much of what S. N. Goitein called the "Middle, Middle Ages" (roughly 800-1250 C.E.) Islamic powers dominated the commerce of the Mediterranean and Indian Ocean and with it, the traffic in domestic, agricultural and military slaves ([17], pp. 237-80). Although the transport of enslaved persons across the Sahara and from East African (as well as from the Caucasus and Central Asia) remained in the control of Muslim polities and merchants well into the nineteenth century, the medieval crusades against Islam redirected the Mediterranean slave trade and changed the confession of its victims. Latin Christendom's territorial conquests in Syria, Anatolia and North Africa proved largely ephemeral. But command of the inner sea coupled with an expanding trade network furnished the merchant marines of cities like Genoa with special advantages over Muslim and Jewish merchants and especially in the traffic in human beings.

The late medieval Mediterranean trade in human beings was skewed by gender. Most captives sold in Genoa's auctions were women and children, products of the mass enslavement of Muslim communities in Iberia and Sicily as well as from raids across the Mediterranean, including in the Maghreb [18-21]. The shifting frontier in Spain, which favored Christian colonization by land, also afforded opportunities for Jewish entrepreneurs to navigate between sides, selling Muslim slaves to Christians ([22], p. 65). At its height, Genoese domination of the Mediterranean traffic in slaves rested on the strategic placement of its entrepôts, including one in the northern Black Sea (Tana) and another in the Aegean on the island of Chios. The Knights of St. John of Jerusalem, which carried out their holy piracy from the island of Rhodes, supplied captives while the Byzantine state and its vassals, as well as smaller Turkic-Muslim states, secured the access points between the Black Sea and the Mediterranean [23].

Given this division of labor, the consolidation of a multi-continental Muslim empire over the next two centuries radically transformed the geopolitical coordinates of commerce overall and with it, the control over the slave trade. As Ottoman armies pushed westward, in fact on the eve of their conquest of Constantinople which would effectively turn the Black Sea into an "Ottoman lake" for the next three centuries, Pope Nicholas V (d. 1455) acceded to the request of King Afonso V (d. 1481) of Portugal for a special bull which would renew crusading privileges in more expansionist terms. Dum Diversas (1452) granted, in effect, the same license and indulgences to the Portuguese king and his heirs (and followers) that had been employed to induct noblemen in the medieval crusades against Islam in the Levant. However, in this and a second encyclical, Romanus 
Pontifex (1455), the pontiff also authorized unprecedented sweeping enslavement privileges to Christianity's conquistadors. In sum, the king was permitted ([24]; [25], vol. 2, p. 469)

to invade, search out, capture, vanquish, and subdue all Saracens and pagans whatsoever, and other enemies of Christ wheresoever placed, and the kingdoms, dukedoms, principalities, dominions, possessions, and all movable and immovable goods whatsoever held and possessed by them and to reduce their persons to perpetual slavery, and to apply and appropriate to himself and his successors the kingdoms, dukedoms, counties, principalities, dominions, possessions, and goods, and to convert them to his and their use and profit...

With Christendom's eastern flank all but lost, there was a tone of urgency in these bulls. They permitted the Portuguese to use force against both Islamic and non-Islamic Africa as well as against the peoples of the African-Atlantic islands. Conquest and colonization in the name of St. Peter would at least create a cordon sanitaire between the advance of Islam and non-monotheistic populations. Of course, by offering a broad, indeed limitless, religious license, these bulls laid the ideological foundations for future Catholic conquests around the world, from West Africa, the Caribbean and Peru to Gujarat and the Philippines. That the Iberian Peninsula itself, after the Catholic conquest of Andalusia and the nearly simultaneous annexation of lands across the Atlantic, became a crossroads of a global slave trade did not diminish the symbolic and strategic centrality of the Mediterranean; nor did it undercut the significance of capturing Muslims and Africans as part of the post- medieval crusader-colonial "prime directive" [26]. Although the suggestion of Bartolomé de las Casas (d. 1566) to alleviate the suffering of the indigenous populations of the Americas through the enslavement of Africans smacks of medieval race prejudice, the Bishop of Chiapas may have actually sought to return to the letter of Dum Diversas which foresaw slavery in and conquest of Africa — not the religiously quarantined Americas — as a means of preventing further "contamination" of the known world by Islam.

In addition to unleashing a global crusade, fifteenth-century papal authority gave new impulse to territorial wars against the leading Muslim powers in the Mediterranean, especially the Ottoman sultans after their conquest of Mamluk Egypt and much of coastal North Africa. The early modern crusade-although uncommonly known as such-legitimized both large-scale holy war and endemic holy piracy. Well into the eighteenth century, Rome dedicated important revenues to the frontline Catholic sovereigns (such as the Habsburg emperors) by redirecting church tithes and other subsidies toward state treasuries. New military orders emerged or regrouped, from the Uskoks of Senj (in today's Croatia) to the Knights of St. John of Jerusalem, who after their rout from the island of Rhodes in the early sixteenth century rebuilt their raiding operations on Muslim military and civilian targets from the islands of Malta and Gozo [27]. Over the centuries, the early modern crusade against Islam sanctified alliances (Liga Sacra), the last of which was declared by the pope in 1684 after Ottoman armies again besieged Vienna ([28], pp. 215-36).

Wars against the Ottoman Empire by land and by sea (as well as intra-Christian competition within Europe during the Wars of Religion) led to a rapid and unprecedented escalation of the size of armies and armadas manned by salaried troops and mercenary battalions ([29], pp. 137-41). The scale of death and captivity increased apace. A single battle might yield thousands of casualties and captives. The carnage of the great battle of Lepanto in 1571, for example, took the lives of some 
30,000 sailors and soldiers. More than 7,000 Muslim captives, most men in the prime of their lives, were distributed to the Spanish, the Venetians and the papacy at the close of the battle, on the basis of their investments in the combined armada [29,30]. Nevertheless, the Ottoman advance went unchecked. In record time, the sultan built a new fleet and, but two years after Lepanto, annexed Cyprus to the empire. If the Ottomans dominated the most important crossroads of the older routes of enslavement (through the Black Sea and via North and East Africa), by the early seventeenth century, the Mediterranean itself, convulsed by nearly constant small scale, "asymmetrical" holy conflicts, also yielded thousands of new victims for sale [31,32].

While armies required free male soldiers or mercenaries, hand- held gunpowder weapons as well as beasts of burden, the seaborne crusade demanded a largely unarmed and coerced labor force. The oarsmen in the galleys and laborers on the docks and in shipbuilding that were required to maintain and power the armadas were supplied in large part or subsidized by confessionalized captives of this permanent war economy, whether they were prisoners of war, victims of shipwreck, or persons kidnapped along the shores and borderlands. For those states that did not join in the new, global crusade from the Atlantic and the Red Sea to the Pacific, a display of military prowess and religious zeal against the Muslims in the Mediterranean also assumed the form of holy piracy. Medici Tuscany, a merchant-state seeking to preserve its autonomy in the face of French and Habsburg territorial pretensions on the Italian peninsula, established the Order of the Knights of St. Stephen, Pope and Martyr in 1561 [33]. Grand Duke Cosimo I de' Medici (d. 1574) served as its first grand master. With the laudable goal of defending Christendom from Muslim raids in the Tyrrhenian Sea, the Medici state reaped both religio-political and economic rewards: its raids and skirmishes with the infidel yielded thousands of men for the oars of its fleet and a steady stream of human beings for sale to other, Catholic states. Perhaps, too, such a conspicuous display of fervor for the faith offset criticism for the relative leniency of Medici policies toward the Jews (and Orthodox Christians) who lived and traded in Florence and Livorno [34,35].

Of course, the holy wars that pitted Muslim states against Catholic powers alternated with cross-religious commerce and even, an occasional inter-faith alliance, the most controversial of which was concluded in 1536 between the French King Francis I (d. 1547) and the Ottoman Sultan Suleyman II (d. 1566). Notwithstanding the ongoing religious conflicts, throughout the early modern period the cultural make-up of the states of the Mediterranean world defied a neat, binary division between Christianity and Islam [36]. Ottoman cities remained resolutely multi-religious while much of Western Christendom was purged of its indigenous Jews, Muslims, and, after the Reformation/Counter-Reformation, its Christian dissenters. The treaties that enabled Catholic and Protestant vessels to harbor in Muslim coastal cities provided no reciprocal privileges for Ottoman or North African flagged ships or Muslim merchants in Catholic ports. Even Venice's famous Fondaco dei Turchi, after the sixteenth century, rarely hosted Ottoman Muslim delegations [37,38]. Catholic merchants and consuls who resided in Istanbul, Alexandria, Aleppo, Izmir, Tripoli and other cities could practice their faith and find moral succor in small communities of practicing Catholics that were supported by Rome and Versailles; they also relied upon political support from the permanent representatives of trading nations. By contrast, no parallel accommodations or political infrastructure for Muslims existed in Latin Christendom (with the possible exception of sixteenth-century Poland and seventeenth-century Dutch cities). In fact, between the mass 
deportation of Iberian Muslim communities, from 1609 to 1613, and the late nineteenth century, no free community of Muslims, including those converted to Christianity, resided within Western Europe.

Like the new Christian captives who were paraded upon arrival to the docks of North African ports ([4], p. 55), the enslavement of Muslims and their public display filled more than practical needs. They became exotic specimens and "goods," trophies in a cosmological conflict. As captives enslaved through an ongoing crusade, the infidels who were brought in fetters to Europe personified the triumph of the true religion over the false and Christianity over the "superstition" of Islam. Depictions of Turks (meaning any subject of the Ottoman sultan from Hungary to Syria or, generically, a person of the Islamic faith) and Moors (a subject of either the deys of Tunis, Tripoli or Algiers or of the sultans of Morocco), as well as the great battles in which infidel men were killed or captured, were celebrated in paint and verse. The enormous figures of Muslim slaves on the columns of the Porta Nuova (1583), at the entrance of Palermo and Pietro Tacca's early seventeenth-century sculpture of the "Quattro Mori," composed of the figures of an enslaved Maghrebian father and his three sons, which forms the base of the statute of Ferdinando I de' Medici (d. 1609), expressed the public identities of regimes, cities and citizens [39].

Livorno in the early seventeenth century counted one of the highest number of servile residents (as a percentage of its total population) in the Mediterranean: roughly one in every 12 of its inhabitants was enslaved ([35], p. 93). For the cleric who compiled the list of the Knights of St. Stephen's valiant victories, it mattered little how the human prizes were wrested from Islam: the sack of the city of Bone/Annaba in Algeria in 1607 was qualified as the "most glorious enterprise ... ever undertaken." It resulted, he bragged, in the carrying off of 2000 Muslims, mainly civilians, of both sexes to Livorno ([40], p. 138; [41,42]). In this period, Muslim children were gifted as trifles for entertainment, like the "lively" young lad referred to in the letter of a cardinal [43]. So great was the nobility's demand for such trophy-human beings in the later sixteenth century, that Pope Paul III (d. 1549) authorized the general purchase and employment of Muslim domestic slaves in Rome itself ([2], p. xvi) (compare [44]; [45], p. 132).

Within the Mediterranean, there is no little doubt that faith played a determining role in the forced transfer of populations. Some states, notably the Knights of St. John at Malta, made confessional identity a zero-sum game. All non-Catholics-Orthodox Christians, Muslims and Jews alike-found aboard Muslim ships could be seized. Until the mid-sixteenth century, Maltese captains would routinely board Venetian ships, confiscating the cargo of Jews and Muslims. Even Jews with the requisite permits and passports would be sent to the slave auctions in La Valletta. ([14], p. 40; [46]). ${ }^{1}$ Yet while all non-Catholic captives from Ottoman lands were confessionalized and, as such, became technically subject to captivity (including, until the early eighteenth century, many Orthodox Christians), their status and hence their fate, were not uniform. Upon disembarkation at the port, before entering quarantine, secretaries and interpreters would record the personal name, place of origin, father's name and distinguishing features of each new captive ([2], p. 74). These scant facts of status determined their destiny; whether she or he would be a candidate

Skippon [46] who visited Malta in the early seventeenth century noted a separate dungeon for the enslaved Jews. 
for ransom, sold to the highest private bidder at auction, or transferred to the dungeon (bagnio) as an addition to the workforce owned by the state treasury or the military order.

Comparisons have been made between Mediterranean confession-based and Atlantic race-based slavery $[4,47]$. Despite the fact that opportunity factors, particularly geography and transport, facilitated who and when persons might be enslaved, there remained significant variables in the processes of confessionalized and racialized enslavement. For a confessionalized captive, whose homelands were proximate, ransom (and even escape) remained more than a theoretical possibility, precisely because ransoms were many times the price of a human being sold at a slave auction. Confessional identity functioned paradoxically: the same identity that rendered the individual vulnerable to enslavement could also afford a critical margin of personhood, which linked him or her to powerful states or to communities of coreligionists of means. In the case of some Ottoman Christians, it might lead to more lenient treatment by their Protestant and Catholic captors ([35], p. 115). Over these centuries, recurrent negotiations between the chief belligerents on land and sea, including Venice, the Habsburg and Ottoman empires, resulted in highly formalized terms of prisoner exchange in diplomacy and truce agreements $[48,49]$.

Unlike the ports of Ghana or the terminus of the trans-Sahara routes in Tunis, where prince and pauper might have shared the same fate, the rank and provenance of confessionalized captives within the Mediterranean continued to play an important role in the treatment of captives overall. Even implacable foes like the Maltese grand masters and the deys of Tripoli concurred that captains of ships (provided they were not themselves converts) must be treated with deference while awaiting ransom or exchange ([14], p. 468). Moreover, it must also be underlined that the distinction between racialized and confessionalized identities was observed within the Mediterranean itself: preliminary censuses make clear that the numbers of East and Sub-Saharan Africans sold into bondage in the early modern period throughout the Mediterranean dwarfed the numbers of either Western Christians or Mediterranean Muslims ([2], pp. 34-9). Thus, for persons trafficked within the Mediterranean, proximity (and with it the possibility of flight) and provenance (which included the supposition that individuals retained ties that might yield ransom or exchange or even sanctuary aboard an allied ship) not only informed their classification as "Turchi" or "Mori," but also afforded them a critical margin of personhood which was denied to human beings labeled "Negri” or "Etiopici' ([35], p. 115; [50]).

\section{The Mediterranean's Galley Complex}

Whether through war, piracy, or shipwreck, once a Muslim fell captive in the western or central Mediterranean until the nineteenth century, he or she remained for a time suspended in the grey zone between temporary prisoner and servile migrant, domestic servant and galley slave. Gender was the first determinant in the fate of a Muslim, Jewish or Orthodox Christian captive. The terms of servitude for confessionalized captives/slaves remained gender-specific. Rank counted less for women, although families attempted to ransom their captive daughters, mothers, and wives, as well as their sons. Muslim women undertook dangerous travels across the sea to raise funds to purchase their own and their family's freedom ([14], pp. 207-8). Most women (including Jewish, African and Greek Orthodox) who were not ransomed were sold to private individuals and put to work in Catholic (and sometimes, Jewish, in the case of Muslim women) homes as domestics and not 
infrequently forced into forms of concubinage. The majority of adult male captives, subjects of the Ottoman Empire and the North African states, became part of a public workforce in the country of capture or were sold to service other Catholic fleets. From that point onward, it was only ethnicity (Balkan or North African origin) point of sale, and price that were recorded in the naval account books, as we find in an extant register from the Port de Toulon, entitled "Bagne des Galères, matricules des Turcs (1682-1707)." In this period, "turc" simply meant galley slave [51].

Although we must resist a facile equation of race and religion in terms of enslavement processes, in an age of quasi-industrialized uses of forced labor, there were other parallels between the confessionalized slavery of the Mediterranean and the racialized enslavement in the Atlantic. The framework developed by Philip Curtin to analyze what he called the "Plantation Complex" in the Caribbean [52], might provide a comparative model to reassess the specificity of galley slavery, an important component of the forced labor systems throughout the early modern Mediterranean. Indeed, both the Plantation Complex and the "Galley Complex" involved a secular, feedback loop linking demand for labor with prevailing technologies of production. It is true that the Galley Complex relied on both (nominally) free and coerced labor forces, in addition to confessionalized slave crews. However, both forms of forced transfer were, to a great degree, determined by the state of technology. If galley slavery ended previous to plantation slavery in the Atlantic, it was not a question of moral outrage or differences in the identities of the enslaved, but of an earlier shift to wind-powered vessels within the Mediterranean. As long as galleys fleets were used for transport, war and piracy in the Mediterranean (and the Baltic), confessionalized enslavement persisted. ${ }^{2}$

Like agricultural slavery in the Atlantic, the Galley Complex was built on pre-existing systems of captivity and enslavement. However, it also reshaped those flows, decisively contributing to the shift in demand from female to male captives [53-56]. A ship with 26 oars required five men per oar and an additional 20 oarsmen in reserve as replacements. Larger frigates might employ 500 men at the oars ([14], p. 339). As the size of the Mediterranean's galley fleets peaked in the late seventeenth century so did demand for able-bodied enslaved, Muslim oarsmen in Catholic ports. By the early eighteenth century, when wind powered vessels replaced ships powered by human strength, particularly among the Atlantic-bound fleets of kingdoms like France, the demand for galley slaves also decreased. It is little wonder that because most Mediterranean corsairs, whether the Knights of Malta, privateers, or the rais of the Maghreb, depended on the maneuverability of galleys to raid coastlines, prey upon merchant cogs, and beat a speedy retreat, especially in calms, the economy of confessionalized enslavement, albeit reduced in scale, would continue into the nineteenth century.

Employing confessionalized slaves satisfied the need for workers in a system so grueling and degrading that it was not possible to rely fully on convicts or conscripted individuals. Condemnation to the galleys remained a dreaded form of punishment and the direct precedent for the totalizing institution of the prison. For many convicts, what was supposed to be a short term at sea became a death sentence. Many men maimed themselves rather than be put to the oars. After a few weeks of confinement in the ships, the stench of human sweat and excrement was overwhelming. Enslaved oarsmen who were chained to their benches could not bathe, change their

2 Davis ([4], p. 9) notes this relationship but does not pursue it. 
clothing or even move to relieve themselves. For weeks they were offered only brief respites for sleep; their rations were made up of a monotonous diet of vegetable and legume soup and bread, although ships took on fresh water and other necessities as required while on patrol ([2], p. 185; [14]) Although concern for the economic losses resulting from the high mortality rates among galley slaves led to the employment of medical staff and the creation of a type of infirmary for those so impaired by disease or injury as to be finally removed from the bench, during the summer months many crew members sickened and died. The plague of 1720-1721 carried off one fifth of France's rowing force ([56], p. 246).

Like much of the Caribbean's racialized slave communities, the servile labor force of the galleys did not reproduce themselves by natural increase. Although a percentage of galley slaves survived for decades, some remaining at the oars into their sixties and even seventies, they were not permitted to marry. Given the morality rates due to combat, occupational injuries and disease, in addition to the sheer exhaustion of the human beings who powered the galleys, replacements were continually sought. While the pontifical fleet at Civitavecchia remained entirely dependent on external resupply, whether by gift or purchase, the Tuscan Knights of St. Stephen became self-sufficient by dint of their own regular, holy depredations as well as the human cargo transported to their shores by privateers. The ransom and sale of slaves was the mainstay of the economy of the Knights of St. John. Maltese auctions annually sent about two hundred human beings to Civitavecchia, the majority of the enslaved being subjects of the Ottoman Empire; they also sold slaves to Italian navies and to France ([14], pp. 241-46). Although France was a signatory to treaties with the Sublime Porte that prohibited the enslavement of their subjects, French consuls doubled as slave procurers in La Valletta and Italian ports. Muslims were sold into slavery by land as well: the Holy Roman Empire furnished Ottoman captives for the galleys of France, and even Malta ([14], pp. 264-70).

The core of the traffic in Muslim slaves corresponded with the changing theatres of war and the establishment of key auction sites between the sixteenth and seventeenth centuries. Despite widespread piracy, slave auctions became concentrated in a number of Catholic ports. As such, over the centuries there were regional, boom and bust cycles. For example, Trapani in Sicily held 5,000 Muslim slaves in 1569, comprising approximately one sixth of its total population. But a century later, the city registered not a single adult slave among its inhabitants. Elsewhere, particularly in trading and crusading ports that relied on galleys, the numbers of Muslim slaves remained constant or grew over the seventeenth century. These ports often received human cargo from privateers as well as from their own slaving expeditions. In Livorno, the slave population reached 3,000 individuals in 1616 (of approximately 37,000 inhabitants); in Naples, between 10,000 and 20,000 individuals, or 4 to 7 percent of its estimated population of 270,000 inhabitants in the early seventeenth century belonged to the state or private persons ([2], pp. 24-31). Given its continuing role as one of the chief traffickers of non-Catholic slaves within the Mediterranean and as a state that issued letters of marque to other Christian entrepreneurs, Malta's cities held more than a thousand Muslims (and other non-Catholic individuals) in bondage at the end of the eighteenth century ([14], pp. 577-83).

Yet the Galley Complex also differed in important ways from agricultural slavery in the Americas. Unlike the plantation system, the actual oarsmen who were enslaved (as opposed to 
convicts and volunteers) were part of a crew owned, maintained and managed by a state or one of the state-like lay religious orders. State-appointed officials fed, clothed and punished them; an overseer was responsible financially for injuries, death, and flight. As a chattel crew, Muslim slaves could be sold along with the frigate. In battle or if the hull foundered upon shoals, chained to their benches, they and not the captain, went down with the ship. At the end of the sailing season, Muslim slaves would be pressed into the construction of public works projects such as bridges or walls in the outskirts of Naples and in Maltese towns of La Valletta and Senglea ([14], pp. 301-05).

Precisely because the Galley Complex was not simply a system of production but a mainstay of the state's defenses, the composition of the labor force was rarely entirely servile. To minimize the risk of rebellion, Catholic fleets typically intermingled Muslim slaves on the bench with Christians, either convicts (including Protestants) or so-called buonavoglie or "volunteers," whom poverty or debt forced to become oarsmen. The proportion of Muslim galley slaves to Christian oarsmen varied from fleet to fleet as well as over time, but seems to have increased as the larger European fleets began to phase out their galleys in the early eighteenth century. In seventeenth-century France, Muslims accounted for about a quarter of all galley slaves, roughly 50 captives for every 150 forçats (convicts) in 33 ships although that proportion might change in large vessels ([51], p. 55; [56], p. 144). In Livorno, the proportion of Muslim galley slaves to either convicts or buonavoglie rose in St. Stephen's crews ([2], p. 31). By 1685, there were 647 Muslim slaves, the majority of whom were of North African origin, to 579 Christian convicts and 181 "volunteers"; similarly, in Genoa, Muslim slaves, who once composed only one quarter of the galley slaves in 1642 , by the end of the century outnumbered the number of convicts (forzati) ([2], pp. 171-77). In mid-eighteenth century Malta, 639 of the 782 men at the oars were enslaved Muslims ([14], p. 345).

\section{Solidarity and Survival of a Forced Migrant Community}

Together the Galley and Plantation Complexes removed millions of individuals from their homes and families and forced them across the sea into perpetual servitude. Chattel slavery throughout the early modern Mediterranean and Atlantic subjected human beings to quotidian brutality, cruel punishments and deprivations; within the Mediterranean basin, Muslim and Christian survivors of captivity recounted comparable horrors. That said, there remained significant differences in the treatment of confessionalized slaves as individuals and groups within "receiving" societies. These conditions patterned and limited the possibility for an individual's integration or absorption into the new society and, hence, reflected more than culturally-specific attitudes or comparable survival strategies. As such, the experience of these displaced persons cannot be fully understood without considering how the confessionalized enslavement of larger groups of individuals produced both a servile workforce and a peculiar migrant community.

For Muslim galley slaves, the structure of their migrant communities and their survival strategies were critically determined by the degree of ostracism and outright hostility of the society in which they spent their lives. Although not all Catholic ports treated these forced migrants with the same degree of exclusion and, in some cases, such as in Marseilles, Balkan Muslims actually enjoyed superior "privileges" to French Protestants, overall there were notable contrasts in the Catholic and Muslim Mediterranean settings. Whereas in many Muslim ports foreign Christians, Jews and members of local Jewish and Ottoman Orthodox communities were a familiar sight to the 
majority society, in Italy and France, aside from the rare appearance of a heavily guarded diplomatic entourage from Persia, Morocco or Istanbul, the only Muslims that ordinary Catholics encountered in their daily lives were the enslaved. Muslim slaves in Malta complained that unlike the practices in Istanbul or the North African ports, they were not even allowed to eat or drink their purchases of food inside shops and taverns with Christian customers, but were forced to take their meals in the street ([14], pp. 124-25).

Muslims in Catholic societies were visually marked. That was not because they maintained the customary clothes of their homelands, such as turbans or long robes; nor did it owe to distinguishing facial features or to skin color. Rather, it was because being dressed and groomed as "turchi" was prescribed by law and the regulations of naval administrations. Their heads were shaved except for a distinctive pigtail ([14], pp. 75-77). Although the ordinary galley slave may have retained a long mustache that covered his lips, only their chaplains were allowed a beard. Clothing too was uniform: a roughly woven woolen cape with a hood. Converted slaves and Muslims alike carried a one to two pound iron footlock around their ankle; Muslims also bore chains or were chained to the little kiosks they were permitted to open on the docks and in marketplaces ([2], p. 88).

Life in port for galley slaves was certainly an improvement over the weeks of torment they endured during the rowing season on patrol and in battle. Nevertheless, both the galley and the prison-like structures called the bagnio (in Genoa, the darsena) which were constructed at the docks to shelter them constituted the Muslim ghettos of early modern Europe. In Malta, more than three prison-like structures were dedicated to housing Muslim and Jewish slaves at night; after 1749, privately owned male slaves were also required to overnight in one of these structures ([14] pp. 93, 440). The French sculptor Charles Marguerite Jean-Baptiste Mercier Dupaty inspected the darsena of Genoa in 1785. In its "low, dark, and dank," masonry chambers he found that younger, active men were chained in cells measuring 6 by 6 feet. This provided just enough room to move and to change their clothes ([2], p. 188).

All of these conditions - the rigors of work and life aboard the galley, their treatment at port, and the hopelessness of a future without the comforts of a familiar culture or family-drove a very high percentage of Catholics and Protestants in the bagnios of North Africa and the Ottoman capital toward conversion ([4,10]; [5], pp. 77-78). ${ }^{3}$ In theory, adopting the faith of the receiving society should have functioned as the primary modality through which the forced migrant might attempt to integrate within or actually achieve some form of "naturalization" in an early modern society. The receiving society's institutional capacity to accept (or deny) converts, in turn, would have played a key role in reinforcing or undermining the bases of solidarities within these forced migrant communities (compare [58]). However, the rate of Muslim galley slave conversion to Christianity remained inexplicably lower than their counterparts across the sea. Part of this may have to do with the method of religious "outreach". A zealous and astute Jesuit in early seventeenth-century Naples who dispatched Arabic speaking priests to the prisons met with greater

\footnotetext{
Article 23 of the French-Ottoman Treaty of 28 May 1740 accepted the inevitability of frequent conversions, establishing procedures for the transfer of property should a commercial factor or sailor convert to Islam. For the treaty see [57].
} 
success; a new Casa dei Catacumeni (a type of half-way house for new converts) for Muslims in Rome which offered instruction in Christianity attracted some slaves ([2], pp. 268-75; [59]). But attempts to proselytize slaves met with opposition from galley administrators. Overseers in the papal port of Civitavecchia complained that even this limited opportunity to receive instruction in a new faith should be discontinued. Catholics should not expect that Muslims would ever really foreswear their faith; it was only abused by "Turks who feign to be Christian until, at the first opportunity, they flee to their homelands" ([2], p. 271).

Although the missionaries were far less successful with adult male Muslims of the galleys, baptism of Muslim women and children in domestic service occurred with some frequency in the early modern period. The fact that most of the conversions in Rome and Livorno were of children or enslaved women ([59]; [2], pp. 276-78), lends support to the supposition that the higher rates of conversion in Muslim lands may partially be attributed to the greater prevalence of household slavery. The Ottoman historian Suraiya Faroqhi observes that slave-owners often pressured their Christian slaves into accepting Islam [60]. But if we consider conversion not as a novelty, a question of force, or an expedient but rather as part of a larger, multi-faceted process of migration and absorption into a new community, it is not only the push factors that might explain an individual's choice to change the beliefs of his or her natal society. Muslim societies, because of the higher number of slaves in homes, the structure of households, and the potential for social mobility despite servile and foreign birth, facilitated this process in ways that Catholic society did not: Islamic laws recognized the free, Muslim status of offspring of a slaveholder and his concubine who, if her child was male, might also demand to be manumitted [61]. Muslim masters of converted slaves often emancipated them and willed them property and support (through endowments). Although both Muslim and Catholic states had a vested interest in keeping their fleets well supplied with slave labor and thus, ultimately, in discouraging mass conversion, it is not surprising to find the Ottoman controller of the state bagnio writing about the rewards due a Catholic slave after his conversion to Islam, which might include a pass to release him permanently from the prison, new clothes, and even a stipend from the treasury. ${ }^{4}$

By contrast, in Catholic lands, the real and anticipated benefits for converts, particularly galley slaves, were modest indeed and rarely involved manumission. In France, the small number of converted "turcs" were not permitted to leave the oars, although they did gain the right to bequeath their meager property upon death ([56], pp. 264, 284). In Tuscany, converts could shed their chains and sleep outside the bagnio but they were still considered "prisoners of war" and hence property of the order ([2], p. 255). Catholicism raised a host of ancillary problems that had no parallel in Ottoman lands or in the North African context where many "Muslim" corsairs were in fact converts from Catholicism or Protestantism. While in the Muslim world, the neophyte was allowed his or her "ambiguous" forms of adherence to the new religion with little scrutiny [63], in Catholic societies an entire multi-state apparatus, the early modern Inquisition, had been created to eradicate such spiritual ambiguity and syncretism of belief, as well as to prevent "backsliding" into Judaism

\footnotetext{
4 For an example from Ottoman archives: see [62]. The controller of the shipyards requested the release of a Maltese by the name of Antoine Tondo; after his conversion; his name was to be struck from registry and he was released from the prison.
} 
and Islam. An abiding distrust of the sincerity of the Muslim (or Jewish) convert affected both laity and clergy in early modern Europe. Even in old regime France where officials increasingly separated the state business of naturalization from membership in the Roman Church, Peter Sahlins did not find a single case involving the "secular" denization of an adult Muslim convert [64] (compare [65]).

Thinking of conversion and the integration of forced migrants in a new society only in terms of "push-pull" factors associated with migration should not allow us to disregard the power exerted by migrant communities over their members. A convert, in addition to potentially forfeiting the remote chance that a prisoner exchange might restore him to his kin and facing the prospects of punishments more terrifying than the galleys if the Inquisition convicted him of backsliding to Islam, also lost the companionship and solidarity of his former co-religionists at the oars. If solidarity among Muslim galley slaves might have been stronger than their Catholic counterparts in Muslim lands, it may have to do with both the relatively limited opportunities for conversion/manumission/naturalization and the slaves' ability, despite (and perhaps because of) local conditions, to create a fairly autonomous social order. Unlike the leadership imposed by religious orders, such as the Trinitarians, or the chain of command binding newer missions sponsored by Louis XIV (d. 1715) to France, which pretended to represent the spiritual and political interests of Catholics enslaved in Tripoli, Tunis, Salé and Algiers, Muslim galley slaves may have achieved greater autonomy because of the absence of on site representatives of their religio-political authorities They elected their own leaders at sea and on land. Muslim chaplains (or judges), called in Italian papasso/papassi or cadi (kadi), had to earn the respect and trust of their co-religionists on the basis of their character, experience and learning ([4], pp. 113-21). Relying on the precedent set by Ottoman and North African tolerance of Catholic missions, Muslim chaplains gained special privileges including the right to dress in a dignified manner, a private room in the prison and exemption from the most degrading forms of manual labor. Chaplains wrote petitions on behalf of slaves and acted as interlocutors with administrators of the fleet in addition to leading prayers ([2], p. 247; [66], pp. 145-48).

Initially, Catholic states conceded few religious privileges to these early modern Muslim migrants. However, Muslim slaves leveraged the asymmetries of travel and settlement between the Muslim and Christian worlds to their advantage. It must be remembered that although no free Muslim communities resided in Western Europe after the Morisco expulsion from Spain, there remained large indigenous and foreign Christian communities throughout the Ottoman Empire and the Maghreb. In addition to thousands of enslaved Catholics and Protestants, many freemen-diplomats, clerics and merchants - settled in the religiously inclusive environment and enjoyed the protection of sultans, governors and deys under bilateral treaties [35,36]. Thus, Muslim galley slaves who took advantage of foreign merchants' willingness to relay letters and to mediate in the collection of ransom funds across the sea [35], also addressed petitions to Muslim authorities about their general treatment and the lack of religious accommodations. In response, the rulers of the Maghreb, in particular, exerted pressure on local Catholics representatives. They threatened to retract normal or special liberties accorded to Christian slaves and the Catholic orders if parallel religious "accommodations" were not extended to Muslims enslaved in Christendom [2,11]. 
Thus, isolated though they remained from the larger society and deprived of the support of free co-religionists, forced Muslim migrants in Italian ports and Malta were able to wrest from Catholic authorities significant concessions with respect to their cultural and religious rights. Consider: at a time when there were no Protestant houses of worship in France, Muslims in Malta and Italian cities prayed according to their own cult in small chapels found within the bagnios. It was the Knights of St. John who may have first permitted enslaved Muslims and Jews a small room or chapel within Malta's slave prisons; by the eighteenth century there was at least one free-standing mosque near the Muslim cemetery at Marsa ([14], p. 447). In Italy, Livorno's prison might have held a chapel by the end of the seventeenth century. It was a common enough practice in Italy, that the Bey of Tripoli was able to prevail over the reluctance of a pope in the early eighteenth century. Reciprocity worked: either Muslims would have their own prayer room in Civitavecchia or all the Catholic orders would be expelled from Tripoli. In Genoa, a chapel was granted in the darsena sometime before 1737 ([2], pp. 242-43).

Naples, perhaps because of its limited commercial interests in Muslim lands, persisted in denying its large slave population any accommodation for the practice of their faith. When the subject of a chapel was broached to the ruling council, it was rejected categorically. Providing Muslims with a place to pray was tantamount to heresy: Catholics would become "co-conspirators" in "the superstition of Mohammedan practice" ([2], p. 245). In other cities, Catholic authorities needed to be "coaxed" by Muslim rulers into granting Muslim galley slaves real estate beyond their ghettos (the ship and the dungeon) for proper burials. In the mid-seventeenth century, the Dey of Tunis warned that he would destroy the Catholic cemetery in his city if papal authorities did not finally provide Muslims with a dedicated burial ground. Genoa pledged to give Muslims burial plots outside the walls of the city, near the beach, in 1711, although they only made good on their commitment six years later. Finally, in 1768, only after it had concluded important treaties with the Ottoman Empire, did Naples' city fathers relent: although there was still no chapel, they conceded a cemetery to Muslim slaves, so that their dead would no longer be left on the road to be eaten by stray dogs ([2], pp. 248-52).

Culture may have reinforced ties of interdependence among Muslim migrants in Enlightenment Europe, but the individual's very survival depended critically on his relationship with his community. A galley slave received a yearly ration of clothing, a bunk, and monotonous daily ration of food with some slight variation including a bit of meat over the course of the month, scarcely enough to maintain his health. To purchase straw for his bunk, to procure sufficient food and some extra comforts, as well as to painstakingly scrimp and save for his ransom over decades, required ingenuity and cooperation. The English lady who visited late eighteenth-century Genoa related that slaves were permitted to open kiosks, "little shops or sheds on the quay," where they sold " pedlary [sic] goods" as a reward for good behavior. Shackled to their kiosks, some tended coffee hearths or set up lemonade stands; "chained in couples" other slaves hawked such items as fish, mats, and knitted goods ([1], pp. 210-12). Muslim slaves had a great deal of mobility around La Valletta and other Maltese towns which enabled them to carry out chores for private persons as well as to engage in little enterprises for their own benefit. Among many different by-occupations, Jewish and Muslim slaves on Malta, to the dismay of churchmen, ran micro- credit operations [14,67]. 
Like their Catholic and Protestant counterparts, Muslims who were fortunate to return home after their captivity in Malta and the Holy Roman Empire have left autobiographical accounts of their experiences [68-70]. However, it is the memoirs of a Huguenot, Jean Marteilhe (d. 1770), who served alongside Muslims during his years at the oars in the French navy, which offers unusually perceptive insights into how these isolated migrant communities survived in the early eighteenth century ([66], pp. 145-48]). Acquainted with many of the "turcs" in Marseilles, Marteilhe found them to be brave, loyal, generous and honest. On shore, Muslims from the Balkans and from the Maghreb dined communally; they shared their food with one another and offered sustenance to non-Muslim galley slaves. Since Muslims had greater liberty to travel into the city than the Huguenots, Marteilhe and his co-religionists asked their help in obtaining supplies and money which were sent from Geneva. This was not a small favor to ask: to collect these funds and distribute among the Huguenot convicts put the Muslim couriers in great danger. Yet, without expectation of material reward, Muslims willingly risked beatings and torture to help the Protestants.

Protestant-Muslim collaboration relied on ties between communities and not simply an individual's good will. Marteilhe's close ties with a courageous ex-Janissary ended abruptly when, in 1708, Yusuf was torn to pieces on the bench beside him as the ship took canon fire upon entering the Thames. Upon learning of his commission with Marteilhe from their chaplain, Yusuf's co-religionists stepped forward to continue his good work. A sympathetic observer of their religious beliefs, Marteilhe directed his reader's attention to the role that Islamic precepts played in helping Muslim migrants survive emotionally and socially in a hostile land. "It must be known that when Turks have an opportunity to exercise charity or other good works, they communicate this joy to their papas, as their theologians are called." ([66], p. 147)

For the Muslim migrant isolated in Mediterranean Europe, thawab (a deed meriting divine recompense) served not only as a principle of mutual aid but also as a source of personal dignity and hope for reward in the afterlife. The moral obligation to carry out such charitable works including the emancipation of one's co-religionists motivated the Alaouite sultan of Morocco, Muhammad III (d. 1790) to embark on a campaign, unparalleled before the French Revolution, to liberate captives en masse. Determined to empty Malta's dungeons of its enslaved Muslims, in 1782 his diplomats initiated complex and difficult negotiations with the Knights of St. John under the auspices of the Spanish court. By the time the final installment of money was paid out to the Grand Master, a year before the sultan's own death, Muhammad III had freed more than 1,000 subjects of the North African states and the Ottoman sultan from life-time bondage at the enormous cost of nearly six hundred thousand scudi. ${ }^{5}$ By means of a supreme act of thawab, in 1789 , for the first time in more than two centuries, not a single enslaved Muslim remained in Malta ([14], pp. 577-83).

5 Consider: the annual income from a particularly large eighteenth-century estate owned by the noble Chigi family of Rome was 8,000 scudi [71]. 


\section{Conclusions: Islamic Diasporas or Returning Europeans?}

By the French Revolution, the decline of the Galley Complex and an enlarged umbrella of diplomatic and commercial agreements binding Muslim and Christians Mediterranean powers reduced the availability and demand for confessionalized slaves in Catholic lands. ${ }^{6}$ Of the estimated half million souls who spent all or good part of their adulthood as forced migrants in early modern Italy alone, several hundred Muslim migrants remained in chains until the arrival of the French Revolution's soldiers and sailors after 1797 ([2], pp. 34-35, 188-89). In Genoa, but four years before the Revolution, a visitor found elderly and disabled Muslims shackled prone to the wooden planks that served as their beds. Shrouded in dirty covers, they were condemned to suffer their last months of life unattended and lying in their own filth ([2], p. 188). Even in freedom, many of former slaves lacked the means and stamina to return to a distant homeland. A visitor to Sardinia in 1812 estimated that more than 80 former "Turkish slaves" had been stranded without "shirts or proper clothes, many without leggings, pale, famished." Left to the mercy of the good citizens of Cagliari, many succumbed to starvation in public view ([72], p. 76). The graphic descriptions of the destitution and degradation of the survivors of decades of enslavement, as well as the cruel indifference of society to their plight, suggest the actual etymology of the term "Muselmänner," which resurfaced in the jargon of inmates of the Nazi death camps during World War II ([73], p. 46).

Despite the disparaging idioms in European languages that bear witness to the centuries of Muslim servitude in early modern Europe [37], there remains no public acknowledgment of their lives, deaths and communal histories. Of course, Salvatore Bono is correct in attributing the suppression of the memory of Muslim slavery during the Renaissance and Enlightenment to colonial burnishing of the West's image [2]. However, there are other reasons why acknowledgment of this history might discomfit the gatekeepers of the European Union today. As Julia Clancy-Smith reminds us, [74] the end of the Galley Complex did not stop the movement of populations between the Muslim and Christian Mediterranean. Rather, the flows and forms of migration were transformed. The French armies and navies that liberated the last captive Muslims in Genoa would later subject North Africa and the Middle East to forms of imperial control. An unprecedented imbalance of power between the northern and southern shores of the internal sea brought tens of thousands of new settlers from the north - the political refugees of the revolutions of 1848, Italian artisans, French engineers, and Corsican colonial farmers-to Muslim cities and countryside [75]. Free emigration of Italy's poor to the "terra promessa" remained a central goal of Prime Minister Giovanni Giolitti's colonial war for Libya in 1912-1913 [76].

The unacknowledged multi-lateral movement of migrants within the Mediterranean from the medieval period until today adds another layer of complicity to the ideologies that have keep these

6 "O Fie, Father! Tho' it Part of your Function to make a dismal Story of Slavery among the Infidels... yet you should, methinks, adhere only to the Truth. You come lately from Marseilles where you must, or might have seen the Turks, Moors, \& c. in much worse Condition than the most unhappy Beylic [sic] Slave in Algiers... You likewise must needs have seen or heard, how Slaves are treated in Spain, Malta, Genoa, \&c." commented the translator, undoubtedly a Protestant, who chastised the authors of Philemon de La Motte's Several Voyages to Barbary [1721] for their imbalanced reporting. ([4], p. 130). 
coerced migrant communities of the Renaissance and the Enlightenment in history's shadows. The long waves of Muslim settlement in the West before the twentieth century challenges cherished myths of cultural uniformity and civilizational superiority that undergird European Union policies toward membership and migration [77]. Pundits and politicians, so fond of pronouncing the death of multi-culturalism and ascribing its inevitable decline to immigrants themselves or to Islam more generally, would have to concede that the integration of Muslim communities in previous centuries failed because the West lacked ecumenical institutions that would allow them (even after conversion) to live as free men and loyal political subjects, and not because of the intransigence of belief or the inability of individuals to adapt to their condition as religious minorities. Textbooks would have to be re-written to reflect the reality that it was the perseverance of Muslim communities of faith and the insistence of Muslim rulers that tested and then put into practice Enlightenment ideals before the French Revolution. Indeed, for European governments, like Germany and Spain, which claim the right to confer national citizenship on long, lost ethnic diasporas or in order to redress historic wrongs [78], public acknowledgement of the almost uninterrupted settlement of Muslim communities in the West from the early Middle Ages to the present forces the real question: Are the Muslims of today's Europe "migrants" at all? Or, are they not in effect returning Europeans?

\section{Acknowledgments}

The seeds of the ideas in this essay first germinated in an interesting discussion that took place between Haideh Moghissi, Tariq Ramadan and myself in Toronto (at the 2007 York University conference, "Muslim Diasporas: religious and national identity, gender, cultural resistance". Comments from anonymous readers and from Carolle Charles, an expert on transnational migration, on an earlier draft helped sharpen the conceptual focus of the essay. All errors are, of course, the author's own.

\section{Conflicts of Interest}

The author declares no conflict of interest.

\section{References and Notes}

1. Annon. Letters from Italy describing the Manners, Customs, Antiquities, Painting, etc. of that Country in the Years MDCCLXX and MDCCLXXI by an English Woman to a Friend Residing in France. London: Edward and Charles Dilly, 1776, vol. 3.

2. Salvatore Bono. Schiavi Musulmani Nell'Italia Moderna: Galeotti, vu' Cumpra', Domestici. Perugia: Universitá degli Studii, 1999.

3. Linda Colley. Captives: Britain, Empire and the World. New York: Anchor Books, 2004

4. Robert C. Davis. Christian Slaves, Muslim Masters: White Slavery in the Mediterranean, the Barbary Coast, and Italy, 1500-1800. Basingstoke: Palgrave Macmillan, 2003.

5. Gillian Weiss. Captives and Corsairs: France and Slavery in the Early Modern Mediterranean. Palo Alto: Stanford University, 2011. 
6. Susan Peabody. There Are No Slaves in France: The Political Culture of Race and Slavery in the Ancient Regime. Oxford: Oxford University Press, 1996.

7. Matti Bunzel. Anti-Semitism and Islamophobia: Hatreds Old and New in Europe. Chicago: Prickly Paradigm Press, 2007.

8. David Brion Davis. The Problem of Slavery in Western Culture. Oxford: Oxford University Press, 1988.

9. Orlando Patterson. Slavery and Social Death: A Comparative Study. Cambridge: Harvard University Press, 1982.

10. Robert C. Davis. "Counting European slaves on the Barbary Coast." Past \& Present 172, no.1 (2001): 87-124.

11. Salvatore Bono. Lumi e corsari. Europa e Maghreb nel Settecento. Perugia: Morlachi Editore, 2005.

12. Schiavitu e Conversioni nel Mediterraneo. Special Issue. Edited by Giovanni Fiume. Quaderni Storici 126, no. 42 (2007).

13. L'ésclavage en Méditerranée a l'époque modern. Special Issue. Edited by Jean-Michel Deveau. Cahiers de la Méditerranée 65 (2002).

14. Godfrey Wettinger. Slavery in the Islands of Malta and Gozo, c. 1000-1812. Valletta: Publishers Enterprises Group, 2002.

15. Géza Dávid, and Pál Fodor, eds. Ransom Slavery Along the Ottoman Borders (Early Fifteenth-Early Eighteenth Centuries). Leiden: Brill, 2007.

16. Patrick Manning. Migration in World History. London: Routledge, 2004.

17. Michael McCormick. Origins of the European Economy: Communications and Commerce, 300-900 AD. Cambridge: Cambridge University Press, 2002.

18. Pieter S. Van Koningsveld. "Muslim Slaves and Captives in Western Europe during the late middle ages." Islam and Christian-Muslim Relations. 6, no. 1 (1995): 5-23.

19. Charles Verlinden. L'Esclavage dans l'Europe médiévale. Vol. 1. Péninsule Ibérique-France. Bruges: De Tempel, 1955.

20. Charles Verlinden. L'Esclavage dans l'Europe médiévale. Vol. 2. Italie, colonies italiennes du Levant, Levant latin, Empire Byzantin. Bruges-Gand: De Tempel, 1977.

21. Olivia R. Constable. "Muslim Spain and Mediterranean slavery: The Medieval Slave Trade as an Aspect of Muslim-Christian Relations." In Christendom and its Discontents. Exclusion, Persecution, and Rebellion, 1000-1500. Edited by Scott L. Waugh and Peter D. Diehl. Cambridge: Cambridge University, 1996, 264-84.

22. Jonathan Ray. The Sephardic Frontier: The "Reconquista" and the Jewish Community in Medieval Iberia. Ithaca: Cornell University Press, 2008.

23. Mihnea Berindei, and Giles Veinstein. "La Tana-Azaq de la présence italienne à l'emprise ottomane (fin XIIIe-milieu XVIe siècle).” Turcica 8, no. 2 (1986): 110-201.

24. Pope Nicholas V (1447-55). "Papal encyclicals." Papal Encyclicals Online. Available online: http://www.papalencyclicals.net/Nichol05/ (accessed on 10 July 2013).

25. Junius P. Rodriguez, ed. The Historical Encyclopedia of World Slavery. Santa Barbara: A.B.C.-Clio, 1997. 
26. Nancy Van Deusen. "Seeing Indios in Sixteenth-Century Castille." The William and Mary Quarterly 69, no. 2 (2012): 205-34.

27. Catherine Wendy Bracewell. The Uskoks of Senj: Piracy, Banditry, and Holy War in the Sixteenth Century Adriatic. Ithaca: Cornell University Press, 1992.

28. Dorothy M. Vaughan. Europe and the Turk: A Pattern of Alliances 1350-1700. Liverpool: University Press, 1954.

29. Charles Tilly. Coercion, Capital and European States (900-1990). London: Blackwell, 1992.

30. Charles Frazee. Catholics and Sultans. The Church and the Ottoman Empire 1453-1917. Cambridge: Cambridge University Press, 1983.

31. Alberto Tenenti. Piracy and the Decline of Venice 1580-1615. Berkeley: University of California Press, 1967.

32. Michel Fontenay. "La Place de la course dans l'economie portuaire: L'example de Malte et des Ports Barbaresques." Annales ESC 43, no. 6 (1988): 1321-47.

33. Elsa Luttazzi, ed. L'Ordine di Santo Stefano e l'amministrazione Delle Sue Fattorie. Pisa: Edizoni ETS, 1999.

34. Francesca Trivellato. The Familiarity of Strangers: The Sephardic Diaspora, Livorno, and Cross-Cultural Trade in the Early Modern Period. New Haven: Yale University Press, 2009.

35. Molly Greene. Catholic Pirates and Greek Merchants: A Maritime History of the Mediterranean. Princeton: Princeton University Press, 2010.

36. Ariel Salzmann. "The Moral Economies of the Pre-modern Mediterranean. Preliminaries to the Study of Cross-cultural Migration during the Long 16th Century." In Living in the Ottoman Ecumenical Community: Essays in Honour of Suraiya Faroqhi. Edited by Vera Costantini and Markus Koller. Leiden: Brill, 2008, 453-78.

37. Paolo Preto. Venezia e i turchi. Firenze: G.C. Sansoni, 1975.

38. Halil İnalçık. "Imtiyāzāt." In Encyclopaedia of Islam, 2nd ed. Edited by Peri Bearman, Theodore Bianquis and Clifford Edmund Bosworth, et al. Brill Online, 2013. Available online: http://referenceworks.brillonline.com/entries/encyclopaedia-of-islam-2/imtiyazat-COM_0371 (accessed on 22 August 2013).

39. Jonaneath Spicer, ed. Revealing the African Presence in Renaissance Europe. Baltimore: Walters Art Museum, 2012.

40. Fulvio Fontana. I pregi della Toscana nell'Imprese piV' Segnalate de'Cavalieri di Santo Stefano dedicated to Cosmo III, Gran Duca di Toscana e Gran Maetro dell'Ordine. Florence: Per Pier Mattia Miccioni, 1701. Repro. Boston: John Adams Library, Boston Public Library, n.d.

41. Marco Gemignani. "The Navies of the Medici: The Florentine Navy and the Navy of the Sacred Military Order of St. Stephen 1547-1648." In War at Sea in the Middle Ages and the Renaissance. Edited by John B. Hattendorf and Richard Watson Unger. Woodbridge: Boyden Press, 2003, 169-86.

42. Moulay Belhamissi. "Course et contre-course en méditerranée ou comment les algériens tombaient en ésclavage.” Cahiers de la Méditerranée 65 (2002): 53-67. http://cdlm.revues.org/36. 
43. "Lettere del Card[inale] Francesco de Medici al Mar[chese] Montauti: manuscript, 1688-1699. Anton Francesco Montauti, Emissary to the Imperial Court at Vienna." Philadelphia, Pennsylvania, U.S.A. Rare Book \& Manuscript Library, University of Pennsylvania, 1688, Ms. 771, letter 1.

44. Natalie Zemon Davis. Trickster Travels: A Sixteenth Century Muslim between Worlds. New York: MacMillan, 2006.

45. Suraiya Faroqhi. The Ottoman Empire and the World around It. London: I.B. Tauris, 2006.

46. Philip Skippon. An Account of a Journey Made thro' Part of the Low-Countries, Germany, Italy and France. London: Lintot and Osborn, 1752.

47. George M. Fredrickson. Racism: A Short History. Princeton: Princeton University, 2002.

48. Pal Fodor. "Piracy, Ransom, slavery and trade: French participation in the liberation of ottoman slaves from Malta during the 1620s." Turcica 33 (2001): 119-34.

49. Joshua Michael White. "Catch and Release: Piracy, Slavery, and Law in the Early Modern Ottoman Mediterranean." Unpublished Ph.D. Dissertation, Department of History, University of Michigan, Ann Arbor, MI, USA, 2012.

50. Jean-Michel Deveau. "Esclaves noirs en Méditerranée." Cahiers de la Méditerranée 65 (2002): 205-18. http://cdlm.revues.org/27.

51. Pierre Boyer. "La chiourme turque des galères de France de 1685 à 1687." Revue de l'Occident musulman et de la Méditerranée 6 (1969): 53-74.

52. Philip. D. Curtin. The Rise and Fall of the Plantation Complex: Essays in Atlantic History. Cambridge: Cambridge University Press, 1990.

53. John H. Pryor. Geography, Technology and War: Studies in the Maritime History of the Mediterranean 649-1571. Cambridge: Cambridge University Press, 1992.

54. André Zysberg. Les galériens. Vies et Destins de 60.000 Forçats sur les Galères de France 1680-1748. Paris: Éditions de Seuil, 1987.

55. İdris Bostan. Osmanlı Bahriye Teşkilâtı: XVII. Yüzyılda Tersâne-i Âmire. Ankara: Türk Tarih Kurumu, 1992.

56. Paul W. Bamford. Fighting Ships and Prisons: The Mediterranean Galleys of France in the Age of Louis XIV. Minneapolis: University of Minnesota Press, 1973.

57. "Capitulations ou traités anciens et nouveaux, entre la cour de France et la Porte ottomane: renouvelés \& augm. l'an de J.C. 1740, \& de l'Egire 1153." Le Mercure de France 908 (1742): 1033-63.

58. Haideh Moghissi. "Introduction." In Muslim Diasporas in the West: Negotiating, Gender, Home and Belonging. Edited by Haideh Moghissi and Halleh Ghorashi. Burlington: Ashgate, 2010, 11-16.

59. Marina Caffiero. Forced Converts: Jews, Christians and Converts. Berkeley: University of California, 2011.

60. Suraiya Faroqhi. "Quis Custodiet Custodes? Controlling Slave Identities and Slave Traders in Seventeenth and Eighteenth Century Istanbul.” In Frontiers of Faith. Edited by Eszter Andor and István Györgi Tóth. Budapest: Central European University and European Science Foundation, 2001, 119-34. 
61. Ehud Toledano. As If Silent and Absent: Bonds of Enslavement in the Islamic Middle East. New Haven: Yale University, 2007.

62. Prime Minister's Archiv (Istanbul, Turkey). Cevdet Collection of Documents, Bahriye (Naval related). 1764, No. 12,215.

63. Bartolomé Bennassar, and Lucile Bennassar. Les chrétiens d'Allah: L'histoire extraordinaire des renégats XVIe et XVI. Paris: Édition Perrin, 1989.

64. Peter Sahlins. Unnaturally French: Foreign Citizens in the Old Regime and After. Ithaca: Cornell University Press, 2007.

65. Nabil Matar. Islam in Britain, 1558-1685. Cambridge: Cambridge University Press, 1998.

66. Jean Marteilhe. The Huguenot Galley-slave: Being the Autobiography of a French Protestant Condemned to the Galleys for the Sake of his Religion. New York: Leypoldt \& Holt, 1867.

67. Michel Acciardi, and [G.P. Agius de Soldanis]. Mustafa Bassa di Rodi. Naples: Appresso Benedetto ed Ignazio Cessari, 1751.

68. Osman Agha de Temschevar. Prisonnier des infidels. Un Soldat Ottoman dans l' Émpire des Habsbourgs. Edited and Translated by Frederic Hitzel. Paris: Sinbad, 1998.

69. Macuncuzade Mustafa Efendi. Malta esirleri. Edited by Cemil Çiftçi. İstanbul: Kitabevi, 1996.

70. Mohammad bin Abd al-Wahab al-Ghassani. "Rihlat al-Wazir fi Iftikak al'Asir." In The Lands of the Christians, Arabic Travel Writing in the Seventeenth Century. Edited and Translated by Nabil Matar. London: Routledge, 2003, 113-96

71. Marco Teodori. "Non solo Rendita. Tipologie Gestionali e Risultati Economici de un Feudo del Lazio del Settecento." In Studi in Onore di Angela Maria Bocci Girelli. Edited by Marco Teodori and Rosa Vaccaro. Milan: FrancoAngeli, 2012, 204-23.

72. Francesco D’Austria-Este. Descrizione della Sardegna, 1812. Edited by Giorgio Bardanzellu. Roma: A.P.E., 1934.

73. Giorgio Agamben. Remnants of Auschwitz. Boston: Zone Press, 1999.

74. Julia Clancy-Smith. Mediterraneans: North Africa and Europe in an Age of Migration c. 1800-1900. Berkeley: University of California Press, 2012.

75. Selim Deringil. Conversion and Apostacy in the Late Ottoman Empire. Cambridge: Cambridge University Press, 2012.

76. Paolo Maltese. La Terra Promessa: La Guerra Italo-Turca e la Conquista della Libia 1911-1912. Milan: Sugar, 1968.

77. Leo Lucassen. The Immigrant Threat: The Integration of Old and New Migrants in Western Europe since 1850. Champaign: University of Illinois, 2005.

78. Gerry Hadden. "Sephardic Jews Invited Back to Spain after 500 years." BBC News Magazine, 13 March 2013. Available online: http://www.bbc.co.uk/news/magazine-21631427 (accessed on 11 July 2013). 


\title{
Rhetorical Conflicts: Civilizational Discourse and the Contested Patrimonies of Spain's Festivals of Moors and Christians
}

\author{
David A. Shefferman
}

\begin{abstract}
The title of this essay identifies a series of verbal scuffles - or "rhetorical conflicts"- that developed in the fall of 2006 within Spain's larger culture wars. The political skirmishes coalesced around an announcement by the Popular Party (PP) to champion a class of regional festivals for U.N. designation as indispensible elements of "human patrimony." The war of words stemmed from the PP's politicization of cultural designations, but the celebrations in question-the fiestas of Moors and Christians common in the south of Valencia region-already generated controversy since they display "rhetorical conflicts" of a different sort: In potentially offensive fashion, the festivals present carnivalesque re-enactments of battles in the medieval "Reconquest" of Iberia by Christian armies over Islamic "Moors." The essay situates these entangled controversies in the broader context of waves of immigration that have accompanied, or even fueled, a trans-Atlantic discourse centered on notions of a geopolitical "clash of civilizations" between Islam and the West. Accordingly, the debates about the Moors and Christians festivals - like the celebrations themselves - reveal deep ambivalence about the role of Islam and of Muslims in Spain's past and present.
\end{abstract}

Reprinted from Religions. Cite as: Shefferman, D.A. "Rhetorical Conflicts: Civilizational Discourse and the Contested Patrimonies of Spain's Festivals of Moors and Christians." Religions 5 (2014): 126-156.

\section{Introduction: Conflicts of Rhetoric and Rhetorics of Conflict}

On Friday, 13 October 2006, Eduardo Zaplana made an announcement that - on the surface, at least - would seem relatively straightforward and cause for excitement and even celebration. In his role as official spokesman for the Popular Party (PP), one of Spain's two main political organizations, Zaplana announced that the PP would present a non-binding resolution (proposición no de ley) in the Congress of Deputies (el Congreso de Diputados), the nation's lower legislative house, supporting the candidacy of a class of regional festivals for international recognition as an indispensible part of "human patrimony." Zaplana explained the specifics of his party's initiative as well as its timing. The PP wanted clear congressional support for Spain's application to the United Nations Educational, Science, and Cultural Organization (UNESCO) to inscribe a number of new elements on UNESCO's list of "Masterpieces of the Oral and Intangible Heritage of Humanity." As Zaplana emphasized, the inclusion of these particular fiestas (festivals) on the list of 
candidates made perfect sense at that moment. Some European organizations had recently declared the celebrations a matter of "international tourist interest" and on the preceding Monday ( 9 October) — only four days earlier - prominent representatives of the fiestas had participated as honored guests in the Hispanic Heritage and Columbus Day Parade in New York. Fittingly, as Zaplana pointed out, the special Spanish emissaries carried out some of the celebrated traditions as they marched down Manhattan's famed Fifth Avenue, only blocks away from the UN headquarters where the world-heritage application would be filed. Using his well-honed skills as a political spokesman, Zaplana made his best effort to give the announcement a festive air. What could be better than celebrating renowned celebrations, than feting famous festivals, than securing them the global recognition they deserved? Zaplana wondered openly how anyone could possibly object to the proposition.

However, in raising that question, Zaplana implicitly acknowledged that there were people who did oppose the Popular Party's plan. In fact, beyond his scripted announcement, Zaplana spent most of the 13 October press conference framing his party's initiative as a deliberate counterattack. In other words, he made clear that the PP's declaration of intentions served as the latest retort in a broader political battle that had intensified during the week leading up to the announcement and in which the traditions lauded by the Popular Party served as the immediate object of dispute. The celebrations that the PP planned to bring to the Congress for validation were Las Fiestas de Moros $y$ Cristianos - the Festivals of Moors and Christians-especially popular on or near the Mediterranean coast in the southern part of the Valencia region in Spain's east. Even before the developments leading up to Zaplana's announcement, the fiestas generated periodic controversy. And, in that regard, the October 2006 debates followed a familiar script. Because the festivals invoke the so-called "Reconquest" of Iberia by Christian forces from Islamic powers, pockets of critics regularly decried the celebrations as symbolically violent and thus offensive, especially to contemporary Muslims. In the late 1990s, public condemnations of the festivals from various quarters began to grow louder and more frequent in conjunction with the increased size and visibility of the nation's population of Muslims from immigration and other factors ${ }^{1}$. In light of the growing presence of Islam in Spain, did the Popular Party really want Congress-much less the

\footnotetext{
For data and analysis related to the increase of Muslims in Spain, see [1,2]. As Gunther Dietz explains, the unofficial count of self-identifying Muslims in the country in 2009 was around 700,000 ([1], p. 3). Alfonso PérezAgote places the count closer to (or even above) one million as of 2010 ([2], p. 230). The majority resides in and around the urban centers of Madrid, Catalonia, Valencia, and Andalusia. Dietz and Pérez-Agote both refer to government assessments as well as to other scholarly studies that estimate that at least $80 \%$ of Muslims in Spain came into residence in the country in the past thirty years as immigrants or as the descendants of immigrants. As Dietz notes, the remainder of the Muslim population is comprised of: (a) Spanish converts to Islam (especially concentrated in Andalusia); (b) longstanding but small, multi-generational communities of Muslim Spaniards; (c) "nationalized Muslims" consisting of inhabitants of Spain's territories in northern Morocco who gained citizenship beginning in the late 1980s. For more specific information on Muslims in the Valencia region, where the Moors and Christians festivals are concentrated, see [3]. As Javier Zapata de la Vega explains in that article, the rapidly expanding presence of Islam in the Community of Valencia since the late-1980s reflects the broader national trends identified above. Labor-related immigration of North African Muslims in the region remains the primary factor. For history and analysis of relations of Muslims and non-Muslims in Spain from the seventh century until around the year 2000, see [4].
} 
United Nations - to sanctify these potentially offensive celebrations as the apex of Spain's cultural contribution to humanity? Or, in fact, was the Popular Party's move a direct reaction to the nation's changing demographics, an attempt to secure global recognition for collective identities supposedly on the wane?

In his 13 October press conference, Zaplana did not address either of those possibilities but instead tried to shift attention away from questions regarding the role of Muslims and Islam in Spain's changing social realities. He attempted to present his adversaries as the problem, painting them as threats to the collective spirit engendered in the festivals as well as impediments to the fiestas' economic and civic benefits: "Under no circumstances will we address the demands of those who try to coerce us. We feel very proud of these fiestas, of this tradition, of this spontaneous demonstration that we live so intensely and of the great splendor they manifest - and which is so important for the development of our tourist sector." Zaplana also made clear that the Popular Party's proposed resolution amounted to a counter-offensive against the ongoing criticisms of the Moors and Christians celebrations, insisting that the effort thwarted "a distinct threat to the liberty of expression, a self-censorship, [that] is spreading" [5,6]. The debates about the festivals continued throughout October in the halls of government, in the press, among families, friends, and neighbors, and in other domains of public discourse. The intensity of the discussions died down over the months that followed, flaring up every few weeks as the press reported on new moves or statements in the political chess-match, until February. That month the Popular Party presented the non-binding resolution on the fiestas' candidacy to Congress as promised, and when the effort failed to pass the battle effectively ended.

Although the disputes beginning in October 2006 about the Moors and Christians festivals followed a familiar pattern - and turned out to be relatively short-lived - the context of the debates nevertheless differed from the past. That environment - the particular landscape of the conflictserves as the focus of this essay. The oppositional language with which I have outlined the topography of events clarifies the first meaning of the title of this essay. Most immediately, I outline here the war of words - the wrangling through rhetoric - that entangled the festivals at the time. In doing so, another connotation of the title quickly arises: Not only did the debates about the Moors and Christians festivals amount to rhetorical conflicts; the controversy also unfolded around a public discourse centered on notions of geopolitical contestation. More specifically, “civilizational" rhetoric_consistent with Samuel Huntington's famous thesis about a post-Cold War "clash of civilizations"-resonated deeply. With the arrival of the fifth anniversary of the events of 11 September, 2001 and only two-and-a-half years after deadly bombings on commuter trains outside of Madrid, considerations in Spain-as elsewhere in Europe and across the Atlantic - swirled around the figure of "Islam" and questions about its fundamental nature and the extent of its reach. Despite important and deep differences of opinion, the collective conversation in Spain advanced on a common ground where "Islam" and "the West" represented two distinct and oppositional entities vying for global power.

In this regard, the dispute in late 2006 over the candidacy of the festivals for "human patrimony" designation serves as only part of a longer series of skirmishes in Spain's ongoing culture wars. The public disagreements about the fiestas that erupted during the first week of October 2006 only made more immediate and contextual a broader set of national, continental, and 
global issues with which Spaniards already had grappled for almost a month. As I explore in detail below, the conflicts over the Moors and Christians celebrations make sense in light of the worldwide debates generated by Pope Benedict XVI's reflections on characteristics of Islam during an academic talk delivered the preceding 12 September. Those issues took on new shape and intensity eleven days later when, during a talk in Washington, DC, Spain's former prime minister, José María Aznar, added to the uproar by following up on the pontiff's speech with his own comments about the role of Islam in the contemporary world as well as in Spanish history. In a peninsula long characterized by diverse and often competing claims of affiliation-be they individual or collective, national or regional, continental or global, religious or secular, to identify only a number of possibilities - the status of "Moors" and "Christians" cut to the heart of apprehensions both historical and contemporary. Accordingly, the rhetoric of "civilizational clash" that framed the public discourse in Spain in late 2006 exposed underlying anxieties regarding issues of immigration and national security. As I show, those pressing concerns exposed fundamental questions of identity and - in a broader sense - of "patrimony."

In that way, the essay's title carries yet-another implication. While the debates played out around a discourse of "culture clash," the fiestas themselves present "rhetorical conflicts," that is, mock performances of past battles between "Moors" and "Christians" as distinct "civilizations" sparring for control of the territory. The rhetoric about the festivals in 2006 paradoxically mimicked the traditional rhetoric of the festivals. And, at that level, the essay's title encapsulates another dynamic: While the notion of culture clash predominates in and provides the structure of the fiestas, the celebrations also include an obvious counterpoint. At a number of points in the performances - and, especially at their climatic moments - the identities of the "Moors" and "Christians" quickly shift and the divisions between them break down. At those junctures, different rhetorics - one of clear separation, the other of equivocality and hybridity - come into dramatic conflict. In the concluding section of the essay, I look closely at one of those critical junctures to show how, in the end, the festive performances call into question familiar claims of identity and of patrimony and, in turn, unsettle Samuel Huntington's "culture clash" thesis in particular and civilizational discourse in general. Accordingly, the festivals, as well as the debates about them, illuminate the profound and ongoing anxieties among Spaniards about the place of the proverbial "Moor" in Spanish history and identity and how those competing sensibilities relate to the social locations - that is, the very real presence - in contemporary Spain of residents still firmly linked in the popular imagination to that Moorish past.

\section{Moors and Christians on the Rhetorical Battleground: The Politics of "Human Patrimony"}

In his press conference on 13 October 2006 explaining the Popular Party's intentions to bring the non-binding resolution to the Congress of Deputies in support of inclusion of the Moors and Christians festivals on UNESCO's list of Masterpieces of the Oral and Intangible Heritage of Humanity, Eduardo Zaplana framed the announcement as a necessary political response to recent criticisms of the fiestas. His characterization surprised some observers for two reasons. First, "world heritage" initiatives traditionally developed in Spain through the coordinated efforts of government agencies and local organizations. Political parties did not claim responsibility for 
instigating such efforts. So why did Zaplana, as the PP spokesman, declare his party would assume that role in this case?

The PP's unprecedented endeavor generated the second point of surprise. Why was the PP pushing for a new legislative measure when, in fact, the drive to secure UNESCO recognition of the Moors and Christians celebrations already had been underway for at least two years? In June of 2004, La Unión Nacional de Entidades Festeras [The National Union of Festival Entities] — commonly known by the acronym UNDEF - announced the organization's commitment "to initiate the opportune labors to secure the declaration of the fiestas de Moros y Cristianos as oral and immaterial patrimony of humanity by UNESCO" [7]. At that time UNDEF also announced the chairs of the commission that would lead the effort: Francisco López Pérez, the newly elected president of UNDEF, and Pedro Escrig Negrete, head of the Association of Moors and Christians Santa Marta of Villajoyosa, a town in the province of Alicante.

The commission, led by its two coordinators, subsequently spent the following years in active pursuit of UNDEF's declared goal. The group did so in the expected and familiar manner, working closely with governmental agencies and U.N. deputies to develop a case and to navigate the application process. As October of 2006 arrived, the commission pointed to a tangible result of their months and months of hard work: some outstanding representatives of the Moors and Christians festivals - a selection from the Alicante town of Alcoy's neighborhood associations - had been invited to march in New York's Hispanic Heritage and Columbus Day Parade [8]. UNDEF and others considered the invitation an encouraging sign that UNESCO eventually would recognize the fiestas with the "human patrimony" designation.

Like many others, the members of UNDEF also understood that - should the campaign achieve its goal - the achievement would culminate a process that began in earnest in the 1990s. During that decade, Spain joined a number of other nations with formal initiatives to establish national and international mechanisms for celebrating and protecting important-and potentially vulnerable-forms and sites of cultural expression. In fact, the Spanish government played a critical role leading to the Proclamation of Masterpieces of the Oral and Intangible Heritage of Humanity by UNESCO's Director-General in 2001, successfully presenting the Mystery Play of Elche that year as one of the first candidates for recognition $[9,10]$. At the same time, the government initiated the recognition process for another popular rite-the famous "Patum" commemoration held in the Catalan town of Berga during Corpus Cristi observances - that finally earned formal "masterpiece" status in 2005.

More broadly, Spanish diplomats spearheaded efforts to expand and to systematize "intangible heritage" mechanisms at both the domestic and international levels. Spain's delegation was instrumental in UNESCO's 2003 draft of a Convention for the Safeguarding of Intangible Cultural Heritage [11]. The Convention provided both an international structure and financial support for preservation of key elements of "living culture." In advance of the Convention's anticipated approval by member states and its assumption of force, the government encouraged entities around Spain to nominate candidates for UNESCO recognition. After more than two years of public discussion and consideration and with the inauguration of the Convention on schedule, the government headed into the fall of 2006 confident that UNESCO would approve its first slate of proposed elements under the new pact. Representatives of the Popular Party proclaimed that, with 
the presentation of its nominees at the major upcoming meeting at the United Nations' headquarters, the time had come to enjoy the fruits of a sustained campaign and, most importantly, to revel in international recognition of Spain's illustrious contributions. Among all the world's nations only Italy had more "world heritage" elements than Spain, and now a significant collection of oral and intangible "masterpieces" would add to that long, internationally recognized list of the nation's outstanding "human patrimony".

This brief review of the development of the international "intangible heritage" movement - and of the particular location of the Moors and Christians festivals within that history-clarifies the reasons why the Popular Party's announcement on 13 October 2006 caused surprise and also why the PP would make that move. Simply put, "world heritage" designations depend on a complex, often tense process carried out across various arenas of domestic and international politics. Much is at stake in those labels as well as for those who get credit for their success ${ }^{2}$. They generate much more than national pride. As almost anybody in Spain-and especially any deputy in its government - understands, U.N. recognition of "World Heritage" sites - like the Great Mosque of Córdoba, Granada's Alhambra, the Royal Palace and Monastery at El Escorial, or Barcelona's Gaudi-designed Parc Güell and Casa Milà-brings substantial economic benefits, including international financial support and status-inspired tourism.

Eduardo Zaplana - and the political organization for which he spoke — clearly understood these high stakes when he announced the Popular Party's unexpected attempt to carry the issue of the "human patrimony" of the Moors and Christians festivals through the doors of the Congress of Deputies and, thus, to politicize the issue explicitly. But why would the Popular Party make that move when it did, presenting these fiestas - out of all the possibilities — as the lightning rod? As Zaplana and the PP also knew, UNESCO and the wider spheres of international diplomacy can serve too as frontlines in the culture wars. The time and place were right to pick up the fight, it seemed. But in order to understand why, we need to consider first the unique character of the object of conflict, that is, of a unique class of festivals that, curiously, dramatize their own version of "culture wars."

\section{The Rhetorical Battlegrounds of Moors and Christians}

While popular studies of the Moors and Christians festivals - including frequents exposés by travel writers and for the benefit of tourists - are extensive, scholarly analysis is more limited ${ }^{3}$. Yet, even a cursory review of this body of literature quickly exposes the cluster of tensions that define the festivals. For example, Moors and Christians celebrations take place throughout much of Spain as well as in areas around the world that belonged to the vast Spanish empire, and the widespread celebrations lay claim to a common format comprising a long-running, far-reaching

2 For more on the history and politics of "human patrimony" movements related to Spain, see [12-16]. [16] focuses specifically on the 2006 patrimony debates surrounding the Moors and Christians fiestas.

3 Below I discuss some good examples of travel writing on the festivals, including [17]. Key scholarly studies of the Moors and Christians festivals are [18-26]. As evident throughout this essay, I build especially on the work of Flesler in [24]. 
tradition ${ }^{4}$. At the same time, each site presents an independent and dynamic iteration of the festival ostensibly based on an exclusive, local history. In every case, the festivals center on a stylized series of battles that adhere to a set structure. Over the course of the festival (usually four to seven days), members of the community re-enact a historical drama defined by a few key plot points. First, a powerful army of "Moors" invades and takes possession of the area, typically marked by the capture of and raising of their flag at the town's main "fortress." 5 . Over the ensuing days of the celebration, a steely and overmatched band of "Christians" face long odds and temporary setbacks, yet eventually defeat and expel the Moorish "occupiers," restoring both land and culture into the fold of Christendom (see Figures 1-4 [27-30]). In other words, each festival re-enacts - in a compressed and schematic form - the so-called Reconquista, or "Reconquest," of Iberia ostensibly completed in 1492. On January 2 of that year Ferdinand and Isabella, Spain's venerated "Catholic Monarchs," secured the takeover of Granada (the peninsula's only remaining Islamic emirate) and, a few months later, issued the Edict of Expulsion requiring all Jews to leave the monarchs' territories by the end of July.

While the common narrative that structures each of the Festivals of Moors and Christians is basic-Moorish invasion followed by the Christians' eventual recovery-the celebrations are, invariably, far from simple. In fact, complexity of detail—or, more precisely, comprehensive spectacularity - functions as the essential characteristic of the festivals, regardless of its scale or duration. The process of amplification begins with the founding historical narratives themselves. As noted earlier, the heaviest concentration of festivals, including the largest and most renowned observances, lies along the coast and in the near-interior of Alicante, Valencia's southernmost province (Figure 5 [31]). Many towns and neighborhoods in and around Alicante city, the provincial capital, also hold celebrations. In each case, the "host" area-whether town, village, or neighborhood - presents and explains the historical events that serve as the basis for their particular observance. For example, in the town of Alcoy-the site of the largest festivals and the source of the 2006 Columbus Day Manhattan marchers_-participants link the celebrations to a battle in April 1276. According to local legend, St. George (commonly known in Spanish as "Matamoros," that is, "Moor Killer") enabled the decisive victory of Christian forces over a powerful Moor army. Thus, Alcoyanos observe their Fiesta de Moros y Cristianos in conjunction with St. George's April feast day. Similarly, Villajoyosa - a village not far south of Alcoy along Alicante's coast and site of another of the most famous festivals - holds its celebrations in July around the Feast of St. Martha, who supposedly came to the miraculous aid of the Christian community in 1538 to repel a Barbary naval assault on the village.

These historiographic justifications often comprise intricate chronicles constructed, preserved and perpetuated by an association of local societies ${ }^{6}$. The network of groups organizes into distinct

4 Hundreds of villages and towns in eastern, southern, and central Spain (in the regions of Valencia, Andalusia and Castile-La Mancha, respectively) hold annual celebrations, and Festivals of Moors and Christians are still common in parts of Mexico and the Philippines. In [26], Max Harris offers a comprehensive study of Mexican variations of the festivals.

5 The castle may be an actual historic monument (cf. Figure 3) or a more modest theatrical construction set up on a local street for the festivities.

6 See [32] for an excellent example from one of Alcoy's most prominent associations. 
units, each with its own identity and shield and known alternately as embajadas (embassies), cuarteles (barracks or platoons), or escuadras (squadrons) (see Figure 6 [33]). In this way, a complex institutional network in each town, village, or neighborhood prepares at length for and then carries out its celebration at a different time-usually during the spring or summer and often in conjunction with the feast day of a particular Catholic saint - and in correlation with distinct historical episodes over the centuries of "the Reconquest." In some places, a unit plays the same role each year but, in many cases, the groups alternate jobs and identities, playing a "Christian" part one year and then appearing as "Moors"- often in blackface (Figure 1) - the next. In addition to the military re-creations - which can involve full caravels arriving by sea (Figure 2) and armies storming a town's medieval castle (Figure 3) - the multi-day celebrations include festive parades of the regiments of "Christians" and "Moors" and impressive firework displays to mark the heroic accomplishments of each army, especially of the "Christians"" final triumph (Figure 4). The costumes and props are extravagant, expensive, and evocative.

Figure 1. A squadron of Moors enters the city. Town of El Campello, Alicante province, 2006.

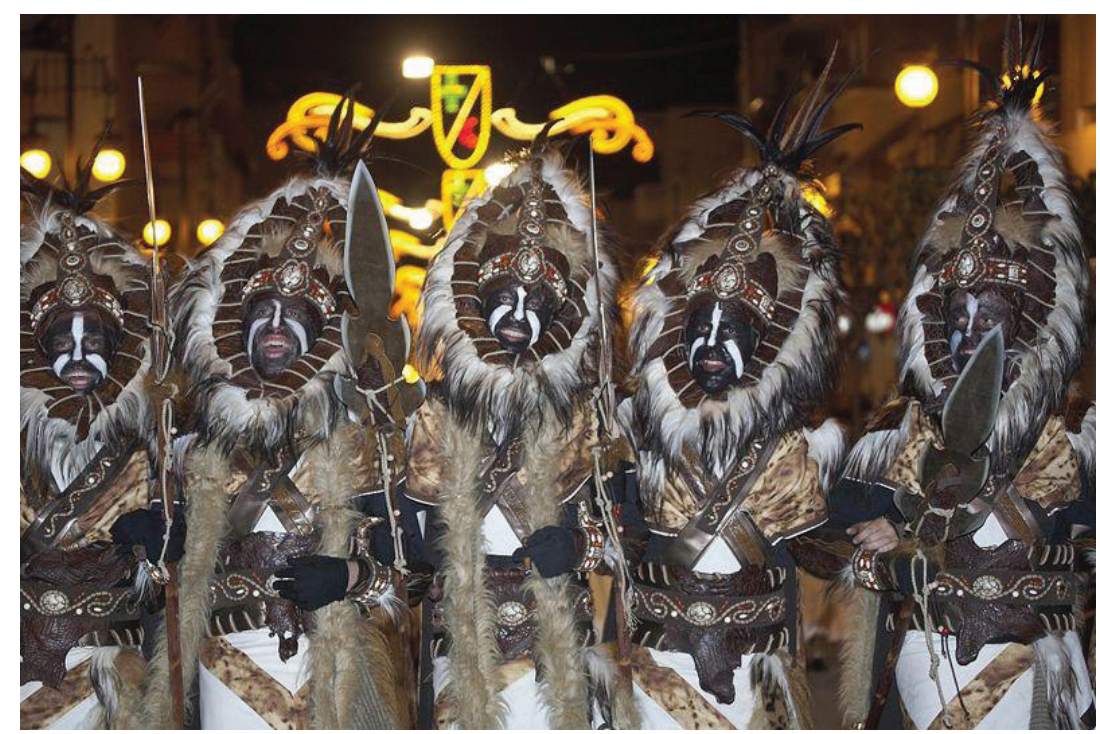

Photo by Bereber. Courtesy of Wikimedia Commons [27]. 
Figure 2. The Moors "disembark". Town of Villajoyosa, Alicante province.

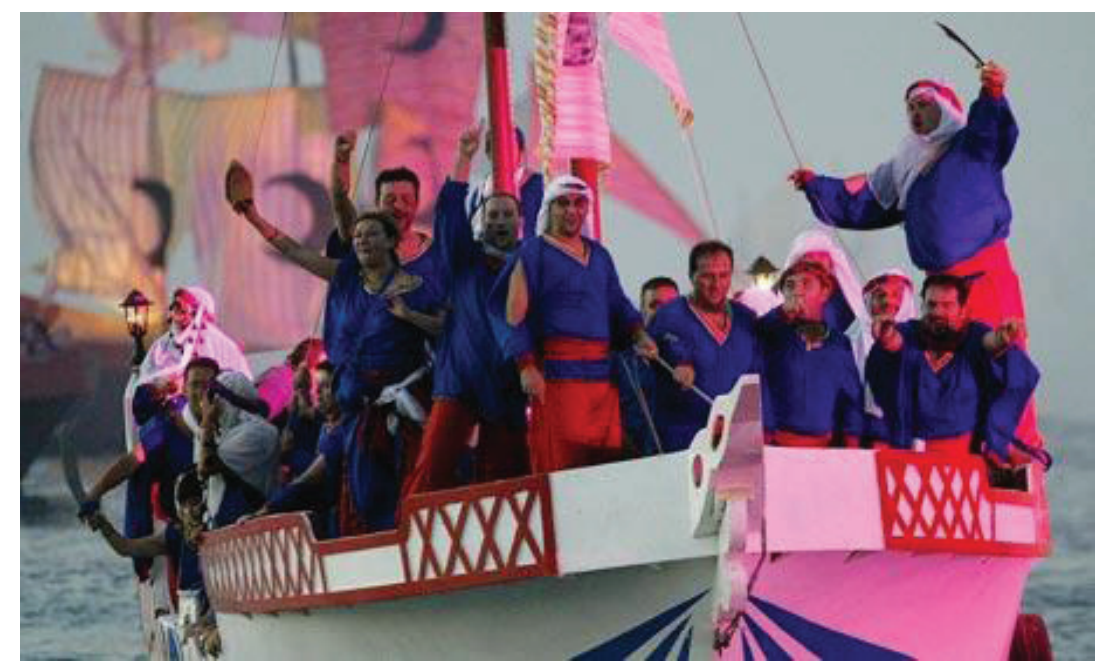

Courtesy of Wikimedia Commons [28].

Figure 3. The battle for the castle. Town of Petrer, Alicante province.

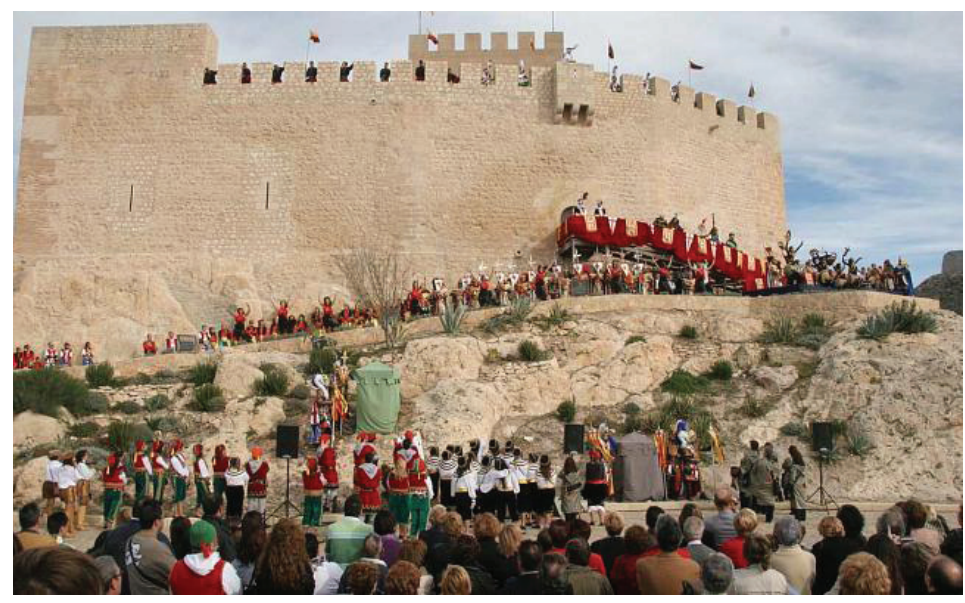

Image provided by Fiestas de Moros y Cristianos [29].

Figure 4. The "Basque Christians" advance, seeking "reconquest". Town of Alcoy, Alicante province, 2006.

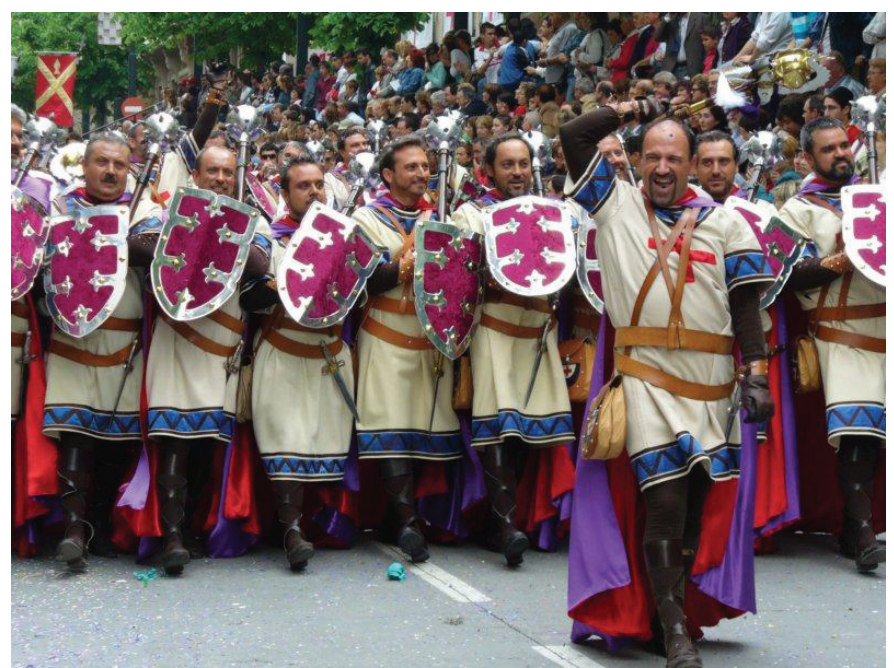

Photo by Popezz. Courtesy of Wikimedia Commons [30]. 
Figure 5. The domain of Moors and Christians: Alicante province, Valencia Community, Spain.

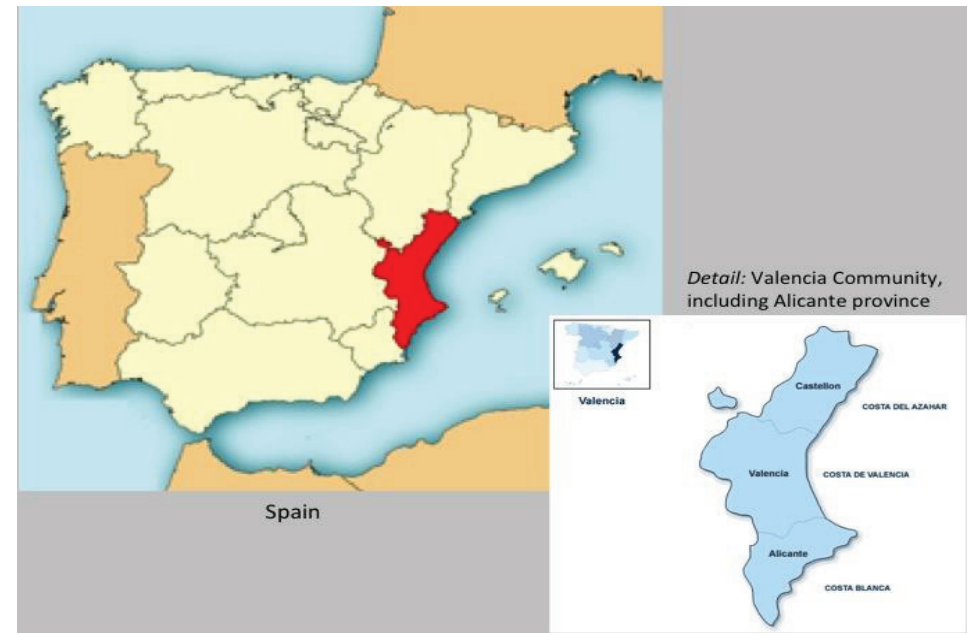

Note: Courtesy of Wikimedia Commons [31].

Figure 6. Sample of shields of association "squadrons" from San Blas neighborhood, city of Alicante.

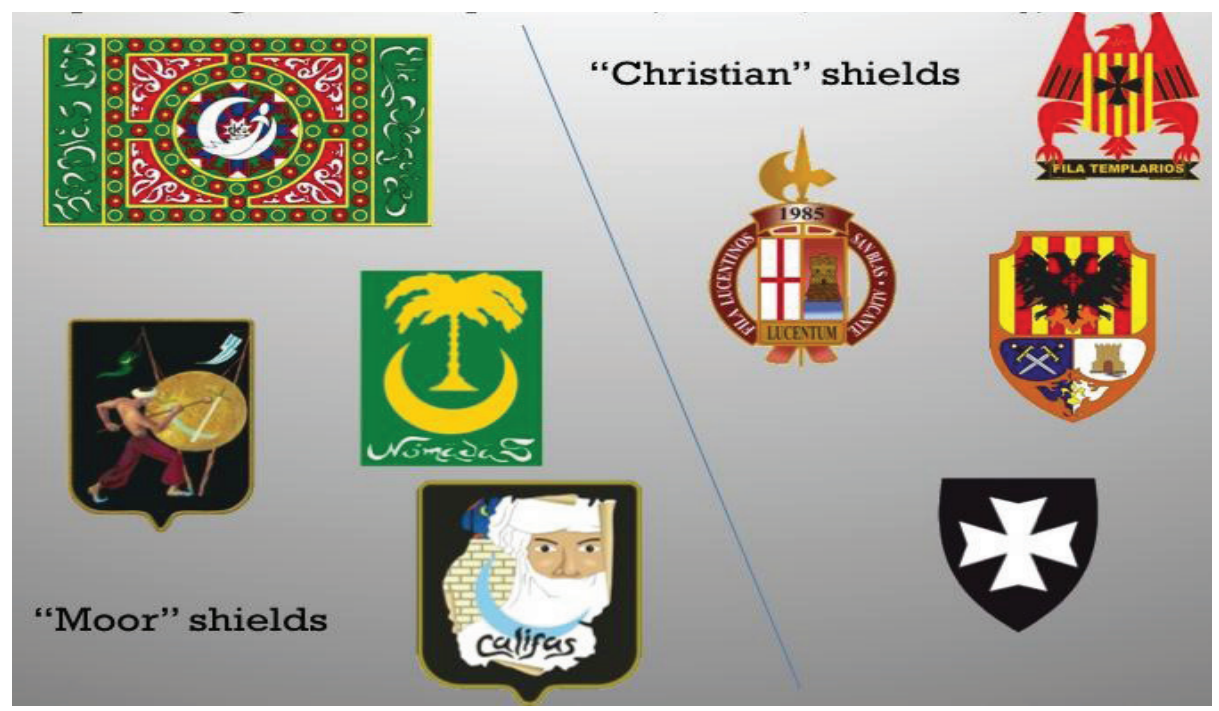

Images provided Asociación de Moros y Cristianos de San Blas [33].

However, these invocations and re-enactments of historical events expose a central tension in the festivals between socio-historical ideals and realities. Most immediately, the fiestas summon "the Reconquest" as a clear_albeit powerful—overarching narrative: The Christian heroes bring Spain out of the Middle Ages and into the modern epoch by restoring the peninsula to its unified and rightful cultural identity after prolonged and oppressive fragmentation under the grip of invading Moors. Yet, at the same time, every version of the festival claims a singular chapter in this broad history. This appeal to historical particularity offers an implicit reminder that "the Reconquest" was not a simple, cohesive, or even linear march to the reunification of Iberia under the banner of Christianity after a long and shameful "interlude" under Islamic Moorish power. The historical realities were much more complex, such that many of the conflicts during the centuries leading up to (and even occurring after) 1492 and now celebrated as part of the teleology of 
"reconquest" actually involved Christians fighting Christians and/or Muslims fighting Muslims ${ }^{7}$. For instance, archival evidence suggests that the occasion for St. George's extraordinary intercession in April 1276 and the source of Alcoy's festive commemoration each year in fact played out as something quite different than a showdown between "Moors" and "Christians." 8 The conflict apparently arose as an episode in the fierce rivalry at the time between the two Christian-led kingdoms of Aragon and Castille ([18], p. 236). Similarly, Ferdinand and Isabella's "defeat" of Granada - typically heralded as the crowning event of "the Reconquest" - ultimately unfolded not as a military victory but rather as Emir Muhammad XII's handoff of control to "the Catholic Monarchs" after months under siege and in the face of potentially worse prospects at the hands of the Muslim Marinids from northern Africa.

Precisely because of such disparities between the archetypal narrative summoned by the Moors and Christians festivals and their underlying historical actualities, the fiestas function as what David Guss identifies as "semiotic battlefields" ([35], p. 10). The audience and actors-all participants in the shared public performances-find diverse, often divergent meanings in them. The representational mechanism of the festivals — the stories, the symbols, and so forth — 'say' and 'do' different things for different people. In the concluding section of this essay I explore in greater depth the points of friction at work in the celebrations. As I show there, the tensions arise not only from the play between schematic invocations of "the Reconquest" and complex, local histories or from competing understandings of the fiestas among participants. Rather, the Moors and Christians observances ultimately publicize and attempt to sublimate the various cultural elements on which modern Iberian identities are founded. In other words, the festivals convey a critical subtext that inherently complicates the bipartite schema of "Moor versus Christian" and the narrative of territorial and cultural reunification that predominates. After all, the maneuvers carried out on the fiestas" "semiotic battlefields" are more intricate than they initially appear.

Nevertheless, as Guss reminds us in delineating conflicting forces at work in certain twentieth-century Venezuelan celebrations, surface appearances matter tremendously in the festive realm. Popular festivals operate with the immediate purpose of conveying and reinforcing specific ideals, even if those principles begin to unsettle upon closer examination or from competing perspectives. Whether employed deliberately or not, public festivities serve as strategic elements in the inevitable politics of culture. The human patrimony debates that arose around the Moors and Christians celebrations indicates the extent to which the cultural politics embedded in this

[34] provides a provocative, popular account of the social and political complexities of medieval Iberia by María Rosa Menocal, a respected scholar of the literature and culture of those epochs.

8 The familiar term "Moor" encapsulates the incongruities between popular conceptions of competing "civilizations" and the historical realities of Iberian culture. The word, derived from Roman designations for a particular North African province (in present-day Libya) as "Mauretania" and its Berber natives as "Mauri" (implying a "dark" hue), assumed more generic meanings in medieval romance languages. By the eleventh century, "Moor" circulated through the Iberian Peninsula in reference, alternatively, to anyone from the north of Africa, to a person of dark complexion and of seemingly African origin, or to any Muslim. Thus, "Moor" became a monolithic (albeit shifting) category for a variety of individuals and groups who made their way into the peninsula over the course of many centuries. In [34] (mentioned in preceding note), Menocal usefully delineates the origins and meanings of the term "Moor" as well as of other common designations of ethno-religious identity that came into popular use over the centuries. 
particular set of festivals connects directly with Spain's long-running tradition of struggles over historical memory. How is the past represented? Where, and by whom? Those questions have led especially to recurring public tussles about conceptions of Iberia's medieval past ${ }^{9}$.

Indeed, as Max Harris explains in his comprehensive account of the parallel development of Moors and Christians observances in Spain and in Mexico, the festivals probably originated in the late 1500 s at the instigation of King Felipe (Philip) II, who famously revised and promoted a variety of traditional celebrations in order to assert Spain's imperial glory ([26], p. 46). When local militias responsible for protecting the coast of Valencia against the Turkish navy and Barbary pirates began to enact mock battles, the king recognized the opportunity to formalize the practice in festive public dramatizations of his forces' victories. Thus was born the tradition of popular fiestas centered on re-enactment of heroic "Christian reconquest" against formidable "Moor" occupiers.

The origins of the festivals more than four centuries ago as instruments of imperial propaganda provide an important reminder of the ostensible function of current versions of the celebrations. While they no longer serve to mythologize Felipe II's empire, the fiestas still explicitly present and support specific myths about Spanish history and its role in shaping national and regional identities ${ }^{10}$. Similarly, the festivals" emergence from the machinations of a "Golden Age" monarch also underscores the specific stagecraft on which the celebrations-then, as now-have always depended in depicting their respective mythologies. In that regard, the Festivals of Moors and Christians have always been decidedly and purposefully carnivalesque. In all of their individual variations and claims to singular historical episodes, the fiestas follow a skeletal structure that is fleshed out in intricate terms in almost every aspect of the festival. As José Luis Bernabeau Rico demonstrates in his pioneering study of the Moors and Christians commemorations, the festivals follow in the grand tradition of the carnavales (carnival celebrations) by constructing parallel universes of time and space where participants might transcend - and ultimately, transform-familiar dimensions of everyday life [19]. At the very least, the celebrations unfold along the lines of what Roland Barthes, in his famous diagnosis of the world of professional wrestling, calls "spectacles of excess." In self-contained arenas, bombastic gestures, symbols, and material accouterments reinforce particular "mythologies" in the clearest and most visceral terms [41]. Similarly, the unrelenting grandiloquence of the Moors and Christians festivals proffer and reinforce the idea of the Christians' triumph — and, thus, the historical process of "reconquest" and territorial

9 There are too many examples to mention of disputes in Spain over historical representation, just as the critical literature focused on the politics of memory is too vast and rich to review here. The debates leading up to and following congressional approval of Spain's Ley de Memoria Histórica (Historical Memory Law) on 31 October 2007 serves as only one obvious and recent example to emerge from the broader socio-political context discussed in this essay. That legislation, sponsored by the Socialist Party and including formal condemnation of measures used by the Franco regime, most specifically addresses issues of public recognition of victims of and participants in the Spanish Civil War (1936-1939) and during the subsequent four decades of Francisco Franco's rule. [36-39] represent some outstanding samples of scholarship exploring the high stakes in the cultural historiography of medieval Iberia.

10 My references to "mythologies" here draw upon Henry Kamen's discussion of "the myths of Spain" in [40]. Kamen identifies narratives of "the Golden Age" (running from the mid-1400s and the reign of Ferdinand and Isabella through the early 1600s and the rule of Felipe II) that continue to shape predominant conceptions of Spanish identity and, thereby, to influence popular discourse and public policy. 
reclamation - as inevitable, even divinely sanctioned. At every turn Moors and Christians appear, in excessive terms, as polar opposites. Undoubtedly, the fiestas operate as rhetorical conflicts, that is, as mock battles and dramatized showdowns between two distinct cultural entities. Was it a strange twist of fate, then, that when the festivals were drawn into other sorts of rhetorical conflicts - wars of words in the political sphere - in the fall of 2006 that the public skirmishes played out, like Moors and Christians celebrations themselves, in terms of a "clash of civilizations"? Whatever the causes for the curious convergence of these various rhetorics of conflict, we need to turn our attention back to the contexts of those debates and the discursive framework in which they played out.

\section{4. "Marching Under New but Often Old Flags": Huntington on "The Clash of Civilizations"}

As 2006 moved toward its conclusion, notions of profound culture clash circulated not only in the Festivals of Moors and Christians but also in public discussion on all sides, and that reality brings me to some of the central concerns of this special issue of Religions and of this essay. Twenty years after its initial proposition, Samuel Huntington's controversial thesis regarding "the clash of civilizations" still holds influence, particularly as it has impacted not only collective discussions about but also public and private actions regarding Islam and Muslims in Europe and North America. The 2006 debates about the Moors and Christians festivals demonstrate the enduring legacy of the "civilizational" approach.

In a now-familiar set of developments, Huntington first floated the idea-in the form of a question - in "The Clash of Civilizations?", an article published in the summer 1993 issue of the journal Foreign Affairs [42]. Since the article "stirred up more discussion in three years than any other article they had published since the 1940" (according to the journal's editors), Huntington offered a self-described "fuller, deeper, and more thoroughly documented answer to the article's question" in a 1996 book framed with a now-declarative instead of interrogative title: The Clash of Civilizations and the Remaking of World Order [43]. Despite the substantially more detailed presentation, Huntington's main premises in the book remained the same as in the original piece. Writing in the immediate aftermath of the collapse of the Soviet Union, Huntington observed that the end of the Cold War engendered:

the beginnings of dramatic changes in peoples' identities and the symbols of those identities. Global politics began to be reconfigured along cultural lines. [...] In the post-Cold War world flags count and so do other symbols of cultural identity, including crosses, crescents and even head coverings, because culture counts, and cultural identity is what is most meaningful to most people. People are discovering new but often old identities and marching under new but often old flags which lead to wars with new but often old enemies ([43], pp. 19-20).

Based on this analysis, Huntington concluded that "the post-Cold War world is a world of seven or eight major civilizations. [...] The key issues on the international agenda involve differences among civilizations. Power is shifting from the long predominant West to non-Western civilizations. Global politics has become multipolar and multicivilizational" ([43], p. 29). Huntington proceeded to delineate nine "major civilizations" (despite his reference to a "world of seven or eight"): "Western, Latin American, African, Islamic, Sinic, Hindu, Orthodox, Buddhist, 
and Japanese" ([43], pp. 26-27). The list already belies his sense of the fundamental role of religion in defining "culture and cultural identities, which at the broadest level are civilizational identities" ([43], p. 20). He highlighted that, even in the "multipolar and multicivilizational" configuration of the new world order, a broadly "religious" division between the Christian-based "West" and "Islam" would continue to deepen as a primary fault line in global affairs.

If Huntington's paradigm generated widespread debate in 1993 and the years following, those discussions now look mild compared to the interest in his self-described "civilizational approach" almost a decade after. Following the events of 11 September 2001, 11 March 2004 and other acts of terrorism, commentators on both sides of the Atlantic and in many spheres of public discourse praised Huntington as prescient and adopted the "civilizational" perspective as an explanatory model for a variety of developments. Still, in all of its iterations and adaptions, proponents built on Huntington's basic assumptions: most immediately, that "the West" and "Islam" represent distinct historical formations guided by fundamentally different - and irresoluble - worldviews currently engaged in a "clash of civilizations" and, in turn, that such "clashes of civilizations are the greatest threat to world peace" and must be diffused by some means or another ([43], p. 321).

\section{Igniting a Rhetorical Fire: Pope Benedict at Regensburg}

Five years after 11 September, 2001, civilizational rhetoric continued to resonate deeply on both sides of the Atlantic. The year began with ongoing and sometimes-deadly protests over cartoon depictions of Muhammad in Denmark's leading newspaper, and the year included a number of other serious episodes stemming from controversial representations of Islam. As 2006 extended into September, many people took the year's developments as clear evidence that a "clash of civilizations" indeed was underway. In a show of respect-but also certainly out of fear for potential backlash - many municipalities in Spain already had altered festive traditions in the wake of the Danish cartoon controversy [44]. Still, in the days commemorating the fifth anniversary of the traumatic events of September 11, the words of one of the world's most visible figures amplified the idiom of "culture clash" - whether by chance or by design - and set in motion the debates that would flare up in Spain the next month over the Moors and Christians celebrations. The sequence began in earnest on September 12 in Regensburg, Germany. It was there and then that Pope Benedict XVI - in the course of a five-day tour of his home country-delivered a talk entitled "Faith, Reason, and the University: Memories and Reflections" to a gathering of eminent "representatives of science" 11 . In the now-famous speech, the Pope argued that the pursuit of truth and knowledge - the modern university's most fundamental task-must proceed from two foundational and mutually constitutive standpoints, namely, reason and faith. Benedict introduced this argument by framing his remarks as a response to his recent encounter with a modern edition of a late-fourteenth-century text-Twenty-Six Dialogues with a Persian (c. 1399) - by the Christian emperor Manuel II Paleologus (1350-1425? C. E.). The Pope used the text as a point of entry into more general reflection on the fundamental historical and philosophical differences between Christianity and Islam and, ultimately, as a means of outlining a mode of rationality that "listen[s]

11 The Vatican's website provides further contextual details as well as the full transcript of the Pope's speech [45]. All citations below derive from this version of the text. 
to the great experiences and insights of the religious traditions of humanity, and those of the Christian faith in particular." To that end, Benedict completed his speech by circling back to Manuel II's manuscript and by letting the Byzantine emperor - in his effort to bridge a seemingly inherent divide between Christianity and Islam — have the final word. He cited Manuel's insistence that God, by nature, calls us to "act reasonably." "It is to this great logos, to this breadth of reason," Benedict concluded, "that we invite our partners in the dialogue of cultures. To rediscover it constantly is the great task of the university" [45].

Despite the pontiff's final invocation of a "dialogue of cultures," it was Benedict's initial discussion of Manuel II's text that garnered widespread attention and incited a global controversy. In setting his agenda, the Pope explained that he "would like to discuss only one point-itself rather marginal to [Twenty-Six Dialogues with a Persian] as a whole"- and turned his attention to the seventh of the twenty-six "conversations" between (according to Benedict's own characterization) "the erudite Byzantine emperor ... and an educated Persian on the subject of Christianity and Islam, and the truth of both." This particular exchange, Benedict explained, "touches on the theme of the holy war," and in it Emperor Manuel

addresses his interlocutor with a startling brusqueness, a brusqueness that we find unacceptable, on the central question about the relationship between religion and violence in general, saying: 'Show me just what Mohammed brought that was new, and there you will find things only evil and inhuman, such as his command to spread by the sword the faith he preached.' The emperor, after having expressed himself so forcefully, goes on to explain in detail the reasons why spreading the faith through violence is something unreasonable [45].

The consequences of Benedict's move, of his decision to include verbatim the evidence of Manuel II's “startling brusqueness," are now well known. The citation made news around the world and provoked fierce reactions. Upon hearing the Byzantine emperor's words uttered by the Holy Father, many people decried the statement as the Pope's unequivocal, general indictment of an inherent violence in Islamic thought and practice. Alongside discussions and debates across the globe about Benedict's intentions, large and heated protests developed at various sites in Turkey, India, Pakistan, Gaza, and elsewhere. By the end of the same week, Benedict felt compelled to offer a public apology and explanation as part of his regular Sunday address: "I am deeply sorry for the reactions in some countries to a few passages of my address at the University of Regensburg, which were considered offensive to the sensibility of Muslims," Benedict stated. "These in fact were a quotation from a medieval text, which do not in any way express my personal thought. I hope this serves to appease hearts and to clarify the true meaning of my address, which in its totality was and is an invitation to frank and sincere dialogue, with mutual respect" (as quoted in [46]).

Indeed, a broad view of Benedict's remarks reveal his emphasis on dialogue and partnership, as demonstrated in his concluding invocations of Manuel's text and in other passages quoted above. Elsewhere in the speech-and even in the same paragraph, when he quotes sura 2:256 of the Qur'an ("There is no compulsion in religion.") - the Pope tries to qualify and to temper the "startling brusqueness" of the Byzantine's remarks. Nevertheless, the wider look at Benedict's speech also makes clear his effort to delineate a clear and deep-seated distinction between Christianity and Islam in order to celebrate the "profound encounter between faith and reason" that 
occurred during the peculiar engagement of Christian theology with classical Greek thought. Building on a critical observation made by Théodore Khoury, the respected editor of and commentator on Twenty-Six Dialogues with a Persian, Benedict underscores Manuel II's key point - "not to act in accordance with reason is contrary to God's nature" - by calling attention to the Byzantine emperor's opinions about how and why Islam strayed from this foundational Christian concept. "For Muslim teaching, God is absolutely transcendent," Benedict summarized. "His will is not bound up with any of our categories, even that of rationality." This perspective theologically justifies even seemingly irrational actions as consistent with divine will. While Benedict does not impute these characteristics onto all Muslims, a particular implication still haunts his discussion: Christianity and Islam occupy distinct theological territories, and the former more naturally reconciles reason with faith.

\section{Throwing Fuel on the Rhetorical Fire: José María Aznar on "Living in a Time of War"}

Pope Benedict's September 12th speech set the stage for the events that developed in Spain over the following month. As in most places, a flood of opinions - from many social, religious, and cultural sectors and across the political spectrum - moved through the peninsula in waves in the days and weeks that followed. Notably, the debates carried out publicly in the media, in the halls of government, among religious communities, and elsewhere quickly shifted from the question of the Pope's intentions - or used that issue as springboard - toward the issue of Islam's essential nature and its implications in the contemporary world. In Spain, as in most places, the discussions centered on the inclusion of those contentious words about the "evil and inhuman" consequences of Muhammad's staggering legacy despite the Vatican's continued insistence that the words were the relic of a medieval text rather than the true sentiments of the pontiff. The focus on that single line suggests that most commentators probably did not bother to read Benedict's fuller statement. And, even if they did, many probably remained confused or underwhelmed by his comparative reflections on the intricacies of Christian and Islamic theological development.

Still, the general disregard for the context of the Pope's citation and the pervasive preoccupation with its ostensible indictment of Islam reveals a curious convergence of perspectives. Lending further credence to Samuel Huntington's prediction that the metanarrative of a "clash of civilizations" would predominate public discourse in the early twenty-first century, the discussion in Spain of the Pope's speech unfolded around the same assumption that structured the lecture itself, namely, that "Islam" and "the West" represented two fundamentally distinct and conflicting ideological entities vying for global influence and power. That symmetry of viewpoints serves as a vivid reminder that, while unique interests and apprehensions in Spanish society would refract public discussion of the Pope's speech in certain directions, the conversations formed part of a spectrum of common concerns in Europe and elsewhere about the nature of Islam and its role in the contemporary world.

Those questions, as they related to Spain and its specific role on the geopolitical stage, surfaced explicitly ten days after the Pope delivered his talk in Regensburg and five days after his public apology for any offense the speech had caused. José Maria Aznar, one of the towering figures in the Popular Party as Spain's former longstanding Prime Minister (1996 to 2004), raised the issues - and added a new dimension to the ongoing debates — while offering some brief remarks at 
the opening reception of a conference on "Global Threats, Atlantic Structures" sponsored by the Washington, D.C.-based policy think tank, The Hudson Institute ${ }^{12}$.

In that context, Aznar took about fifteen minutes to provide some general reflections on the conference's broad theme. He emphasized the need for the U.S., Spain, and other long-standing allies to recommit, even after the end of the Cold War, to "the Atlantic alliance" formalized after World War II in the North Atlantic Treaty Organization (NATO) as a means to confront Soviet power. NATO remained essential, Aznar asserted. While it was still needed to contain post-Soviet Russian influence, the Atlantic states now faced another, even more nefarious threat: "radical Islam." Aznar delineated the current state of global affairs as a matter of stark contrasts. He identified "the West" as civilizations stemming from western European culture and, therefore, rooted in Christianity. ("It's impossible to explain Europe without Christian roots," he insisted again and again [47].) Because the Atlantic connected most of this "civilization," a strong transoceanic alliance was indispensible to the survival of "the West." In his view, survival remained the immediate reality in the face of the ascendant rival civilization he figured as "Islam." "We are living in a time of war," Aznar explained. "It's them or us. The West did not attack Islam; it was they who attacked us." He continued: "We must face up to an Islam that is ambitious, that is radical and that influences the Muslim world, a fundamentalist Islam that we must confront because we don't have any choice. We are constantly under attack and we must defend ourselves." In framing these comments, Aznar not only vigorously defended the Pope's efforts at Regensburg to consider the theological roots of this "ambitious" Islam but also tried to redirect the outcry back at Benedict's critics. The Westerners who take issue with the Pope are "soft," Aznar contested, and take their cue from some of their own "leaders who don't believe in the West." Accordingly, the most "decisive task" we now face is a "battle of values" to preserve and to promote "Western civilization" [47].

Despite their "startling brusqueness"- to borrow Benedict's description in the Regensburg talk of the words of another, much earlier critic of Islam-Aznar's comments came as little surprise. Both during and after his tenure as Prime Minister, Aznar had been one of President Bush's most vocal supporters in the so-called "War on Terror." Despite the opposition of a majority of his compatriots, he had committed Spanish troops and material support to efforts in Afghanistan and Iraq. Moreover, many observers attributed Aznar's political undoing to an Al-Queda-linked terrorist cell that, through a series of coordinated explosions on March 11, 2004 along one of Madrid's commuter train lines, killed 191 people and wounded around 1800 more. The attacks occurred three days before the general elections that voted Aznar's party out of office amid a swirl of questions and suspicions about his government's handling of the situation.

Still, in the midst of the debates already taking place about the Pope's Regensburg speech, Aznar was bound to draw attention for his austere view of Islam and its "war" on "the West." Even so, his biting comments did not end with his prepared remarks. Upon finishing them, he took a number of questions from his audience. One woman asked him to speak more specifically about

12 The Hudson Institute website provides summary details about the conference [47]. The page also includes a link to the complete audio record of the reception, including Aznar's remarks, audience questions, and responses. Citations below refer to the audio file provided there. For further information on the proceedings, see also [48] and [49]. 
"Spain's views of Islam" today in light of its long historical presence in and deep influence on the Iberian Peninsula, beginning with the successful military campaigns of North African "Moors" in the early 700s until Ferdinand and Isabella's takeover of Granada in 1492. Aznar acknowledged that history, but added: "It is interesting to note that, while a lot of people in the world are asking the Pope to apologize for his speech, I have never heard a Muslim say sorry for having conquered Spain and occupying it for eight centuries" [47]. He concluded by invoking the expulsion edict by "the Catholic Monarchs" five centuries earlier, implying a need for a renewed effort — both in and beyond Spain - against the ambitions of the "radical" Islam that, to him, presented a real and severe threat. "I support Ferdinand and Isabella!" Aznar proclaimed. "They were a great king and queen" [47].

Aznar's unwavering endorsement of Ferdinand and Isabella - in a speech on global security, no less - pulls the Festivals of Moors and Christians back into view. After all, the festivals dramatize and commemorate precisely that history of Moorish "conquest" and Christian "reconquest" invoked by Aznar. And, just as a whole slew of questions circle around the implications of the festivals and their grandiloquent representations of Spain's medieval past, a flood of responses and interpretations followed Aznar's declaration that present threats to global security connected directly with Iberia's historical "clash of cultures." ${ }^{13}$. Aznar's comments quickly intensified the public discussion already underway about the Pope's Regensburg speech and its implications. However, Aznar's remarks also introduced a host of new questions and considerations into the discussions sparked by Benedict. Was there merit to his clear association between the complex, centuries-long cultural and political conflicts of medieval Iberia and the current state of world affairs, more than half a millennium later? Was the world population in 2006 really "living in a time of war," much less one between "Islam" and "the West" that essentially stretched back to Islam's origins in the seventh century?

Yet, despite the efforts of various commentators to isolate Aznar's views as idiosyncratic ${ }^{14}$, the uproar they caused reveals the wider socio-political stage on which the Moors and Christians festivals - and the debates about them - took place. The context becomes even clearer in additional comments that Aznar made in the concluding portion of his Hudson Institute talk. In the final question of the night, a member of the audience pressed Aznar for his views about the Alliance of Civilizations. He referred to the initiative brought in September 2004 to the United Nations General Assembly by José Luis Rodríguez Zapatero, who - as head of the Spanish Socialist Party and one

13 A cursory review of the Spanish press in the days following Aznar's speech indicates the abundance and passion of reactions to Aznar's statement from various perspectives. For the week beginning on 23 September 2006-the first day of the news cycle in Spain following Aznar's speech-virtually every major Spanish media outlet, including the state-run RTVE, private radio and television networks, and the country's most widely read dailies and weeklies, featured multiple stories on Aznar's comments and of the diversity of responses to them. For instance, 20 minutos - a popular (and free) daily with an active Internet presence — received almost 1400 online comments on its initial report about Aznar's remarks [50]. Similarly, in its popular Sunday edition on September 24, El País-Spain's highest-circulating and most respected newspaper-showcased reactions to Aznar's speech from some of the nation's prominent religious and political leaders [51].

14 Even Mariano Rajoy, Aznar's successor as head of the Popular Party, tried to distance himself and the party from his predecessor's comments. When asked to react to Aznar's statements, he said: "I am not responsible for the past, neither Franco nor of the invasion of the Arabs. I take care of the future" [51]. 
of Aznar's longtime critics and political rivals-succeeded him as prime minister in 2004. In the aftermath of the bombings of the trains in Madrid that year, Zapatero called for the U.N. to take the lead in fostering international cooperation in overcoming problematic divisions between cultures, particularly the deadly opposition between "Islamic and Western civilizations." ${ }^{15}$. Turkey's prime minister, Recep Tayyip Erdoğan, co-sponsored the initiative, and on 14 July, 2005 the U.N. Secretary General announced the formal launch of "an Alliance of Civilizations aimed at bridging divides between societies exploited by extremists" and outlined the expectation of actionable recommendations by the end of 2006 that U.N. member states could adopt ${ }^{16}$. Since the High-Level Group charged by the U.N. with developing those recommendations stood on the verge of releasing its final report at the time of the Hudson Institute conference, the questioner reminded Aznar, "Your party in Spain has been very critical about this idea launched by the current prime minister. But then President Bush and Secretary Rice have endorsed this idea of the Alliance of Civilizations as a way of engaging Islam in a dialogue - at least moderate Islam - so what's your take on this project?" Once again, Aznar pulled no punches in his reply. "For me, the Alliance of Civilizations is stupidity," he quickly retorted. "I'm in favor of a dialogue between civilizations. [...] But what does it mean, the 'alliance of civilizations'? That we in the European Union, or the United States, should be in alliance, for example, with the Ayatollah's regime? This is another 'civilization'?" [47].

At first glance, Aznar's immediate dismissal of the Alliance of Civilizations initiative set in motion by Zapatero as sheer "stupidity" reveals the former prime minister's deep political and ideological antipathies toward his successor ${ }^{17}$. He underscores his opposition to the idea of excessive collaboration and insists that it is endemic to Zapatero and some of the other world leaders who, in preceding portions of his talk, he explicitly identifies as "soft." In assessing diplomatic strategies, he explains that "alliances" should be reserved for allies, for those who share your "way of life," so that you can "dialogue" with your adversaries from a position of cultural unity and political strength. Nevertheless, the audience member's question about Aznar's "take" on the Alliance of Civilizations already points to the significant common ground between Spain's political rivals. Zapatero's proposal of an "alliance of civilizations" serves as a clear signal that, although his tactics may have diverged substantially from Aznar's views, both men accepted the kind of "civilizational approach" to global politics outlined by Samuel Huntington. Each operated with the notion that the dynamics among fundamentally different cultural blocks - and especially the opposition between radically opposed coalitions of "Islam" and "the West"-defined

15 See [52] for the full text of Zapatero's initial presentation of the idea at the U.N.

16 The opening of the statement reads: "The Secretary-General is pleased to announce the launch of an initiative for an "Alliance of Civilizations". The initiative is intended to respond to the need for a committed effort by the international community - both at the institutional and civil society levels - to bridge divides and overcome prejudice, misconceptions, misperceptions, and polarization which potentially threaten world peace. The Alliance will aim to address emerging threats emanating from hostile perceptions that foment violence, and to bring about cooperation among various efforts to heal such divisions." [53].

17 Zapatero's idea for the Alliance of Civilization, and the contrast of his positions from Aznar's assertions about Spain as "Christian," developed in part from his active and ongoing relations with communities of Muslims in Spain, especially groups of Spanish converts to Islam. For more on these developments, see [54]. I thank one of the anonymous reviewers of this essay for calling attention to this point. 
contemporary affairs. Accordingly, both men - or, more precisely, the major political parties they represented - sought to pursue their different "civilizational" strategies through domestic as well as international political mechanisms. When Aznar delivered his talk at the Hudson Institute conference in Washington, DC in late September 2006-two weeks after Pope Benedict's Regensburg speech and two weeks before a slate of activities scheduled around Columbus Day and Hispanic Heritage celebrations in New York-discussions about U.N. proposals already reverberated across the Iberian Peninsula as part of a much wider set of debates about politics, religion, immigration, and culture and about the role of each of those elements in shaping who Spaniards "really" were and wanted to be.

\section{Back to the Battlegrounds: Moors and Christians on the Rhetorical Front}

Against the critical backdrop of the developments of the preceding weeks, we can return to where we started - October of 2006 - and see more clearly how the Moors and Christians festivals surfaced at that moment as a flashpoint in Spanish public discourse. With continued coverage in the press about Aznar's comments and the reactions they provoked, the fiestas moved directly into the political spotlight. On October 4, Félix Herrero-the president of the Spanish Federation of Islamic Religious Entities and imam of the Union Mosque of Málaga-made the key move, narrowing the broad discussion of the role of Islam in Iberian history and culture toward more focused consideration of popular representations in Spain of Muslims. In light of Pope Benedict's and Aznar's speeches, Herrero offered the Moors and Christians festivals as an obvious and significant example. He issued a public statement in which he challenged the validity of the fiestas and their portrayal of Muslims of the past, insisting that they negatively impacted Muslims of the present. Herrero called for the immediate suspension of the festivals. They "have no place in the democractic Spain of today," he asserted. "In the service of the goal of peaceful coexistence [buena convivencia] these festivals should disappear" ([55]; see also [56]). He objected especially to a component of certain celebrations in Alicante province, like those of Bocairent and Beneixama. In those towns, the fiestas included a tradition in which the victorious Christians, after their final triumph over the Moors in the re-enactments, burned an effigy, called "El Mohama"-a clear reference to Muhammad - carried by the Moors' front guard throughout the festival as a literal figurehead. In the course of the following days, festival organizers in both towns agreed to suspend the "Mohama" burning.

But, of course, the timing of the imam's criticism of the festivals was not accidental. Building on the long-running efforts of UNDEF and of Spain's diplomatic mission, La Asociación San Jordi [The Association of St. George], which oversees the town of Alcoy's renowned Moors and Christians celebrations, had spent months preparing to send representatives to New York to march as Moorish and Christian "squadrons" in the upcoming Columbus Day and Hispanic Heritage parade. Imam Herrero was well aware of the mission's intentions to apply for human-patrimony recognition. And there too his intervention proved effective. On October 6, the organizers from Alcoy, which hosts one of the oldest, largest, and most elaborate celebrations each year, decided at the last minute to break with their long-running and much-cherished tradition by changing their plans for the parade in New York. The group decided that the Christian regiments would march alone, without the squadrons of Moors (Figure 7 [57]). Javier Moreno, the president of La 
Asociación San Jordi, denied that pressure following Imam Herrero's objections made any difference to the group's representatives in New York. "It's possible that the presence of the Moor [squadrons] could wound some sensibilities," he acknowledged after announcing the decision, "but if they're not here it is simply because that the Christian procession has more rhythm than the Moor one, and was better to head the parade" [58]. He added: "In Alcoy there are no polemics. Other people create polemics with declarations that are respectable but gratuitous. All of the squadronsMoor and Christian alike - represent the people." With similar assurances that the decision was "exclusively a matter of infrastructure," Amparo Ferrando-Alcoy's Councilor of Tourism as well as one of the Popular Party's national deputies - insisted, "our festivals portray historical events and are not a matter of, nor offensive to, any particular religion" [58].

Despite these explanations, many supporters of the festivals took issue with the decision to abandon the Moors. The debate about the fiestas — beginning with Herrero's initial statement on 4 October-had garnered widespread coverage in the national press throughout the week and, with the news of the Moorish squadrons' absence from the New York exhibition, the Popular Party decided to act. The stage was set for Eduardo Zaplana's announcement on Friday, the thirteenth, that the PP would bring the non-binding resolution to the lower legislative house to win support for the festivals' "human patrimony" candidacy. As Zaplana asserted in explaining the unprecedented move, the Popular Party saw the need for a courageous counterattack in order to defend free expression in the face of the "debilitating self-censorship" recently on display with regard to the fiestas.

Figure 7. 'No more Moors!' A Christian squadron from Alcoy (province of Alicante) marches alone, without traditional Moorish counterparts, down Fifth Avenue in New York's Hispanic Heritage and Columbus Day Parade, 9 October 2006.

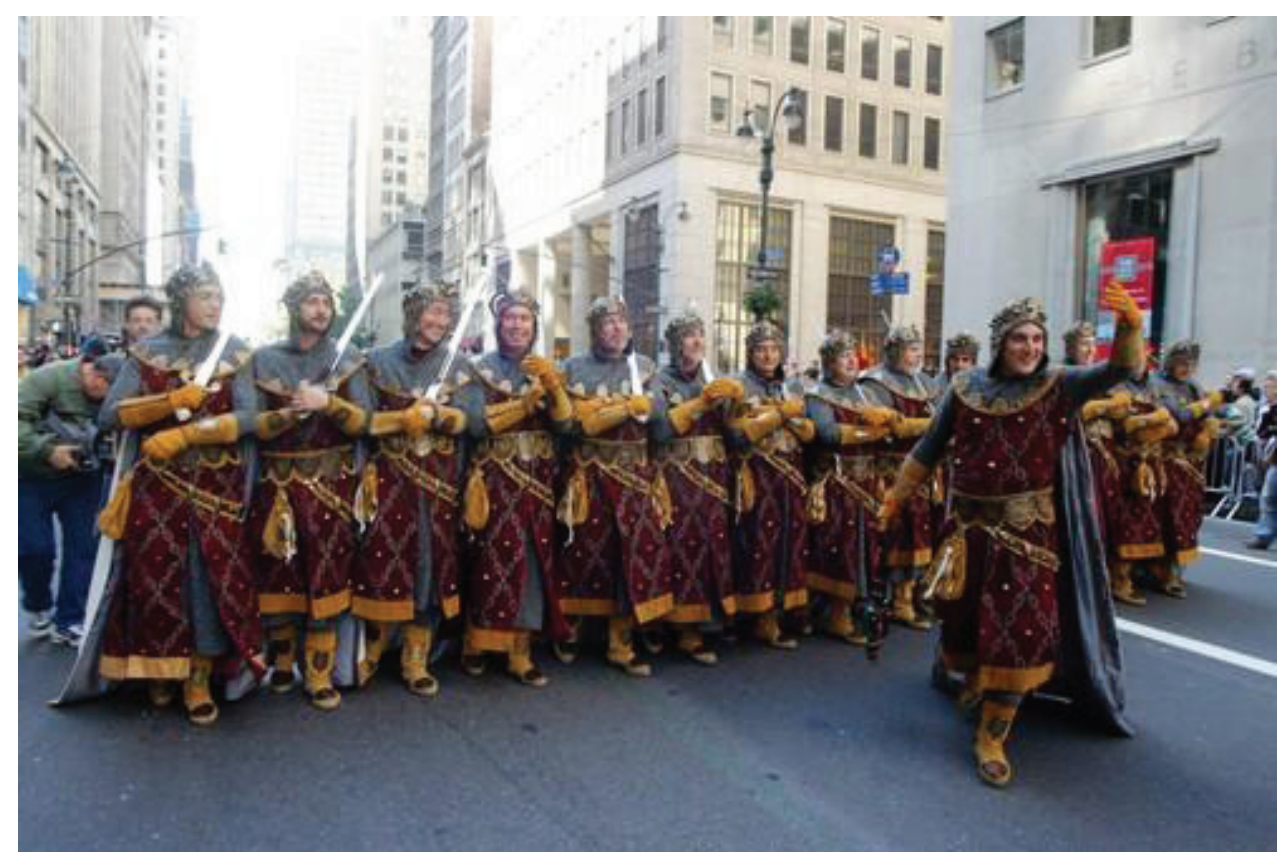

Photo by Miguel Rajmil/EFE [57].

The Popular Party's move complicated the ongoing public discussion of the festivals. Although the party took up the cause of promoting the Moors and Christians celebrations for UNESCO 
designation, local representatives of the festivals strongly criticized the initiative. UNDEF should coordinate the effort, they noted, not some political organization. As one member of the UNDEF commission put it, the process of applying for international recognition "should be separate from any opportunistic and electoral maneuver ... to confuse our respected celebration with politics" [59]. Accordingly, Zaplana's announcement effectively shifted the national debate away from questions about Islam and representations of Muslims to the issues of politicization of local traditions. The driving concerns became a matter of who has the right to represent popular celebrations - the Moors and Christians festivals or otherwise - and how to do so. In this way, the fiestas remained in the press and part of the national conversation for the next month and a half ${ }^{18}$. Finally, on 21 November, UNDEF filed a formal petition with the Spanish government to direct the process of filing for UNESCO recognition, undercutting the Popular Party's efforts to take control of the issue. Even though political skirmishes - and public interest in them-continued through February, when the Popular Party eventually presented the fiestas to the national legislature for UNESCO candidacy, the measure never came before the full Congress of Deputies for approval ${ }^{19}$. Public debate about the festivals largely died down. With or without UNESCO's official stamp, townspeople and tourists continued with their preparations for and participation in the celebrations ${ }^{20}$.

\section{Final Battles: The Fiestas Un-Moored}

Although the political showdowns over the Moors and Christians festivals finished with more whimper than bang - and also proved, after all, fairly short-lived - the episode demands a bit more consideration. In the concluding portion of this essay, I want to return briefly to one of the climactic moments in the series of developments that played out in the wake of Pope Benedict's Regensburg speech. As noted earlier, the announcement on October 6 that the Alcoy representatives in New York would march without squadrons of Moors marked a critical moment in the public debates that had developed in Spain about Islam and its place in the history and culture of the Iberian Peninsula. The decision not only sparked widespread discussion but also provoked the Popular Party's legislative initiative.

Upon closer examination, the explanations offered by Javier Moreno and Amparo Ferrandotwo of the officials responsible for the decision quoted earlier - are similarly provocative. Whether or not Moreno and Ferrando really believed what they said-namely, that political pressures did not play, or should not have played, a part in the decision to keep the Moor squadrons out of the New York parade - a sense of understandable uncertainty and defensiveness inhabits their explanations. As primary spokespeople for Alcoy participants, both speakers acknowledged that

18 See, for example, [59,60]. [61] offers a helpful archive of press coverage of the political debates about the festivals.

19 In September 2012, the Popular Party tried to initiate the process for UNESCO certification once again [62]. This effort also failed but set off a new round of discussions about the festivals and their implications. Comparison of the debates of the fall of 2006 with those from the fall of 2012 remains a task for future study.

20 In fact, the Moors and Christians fiestas continue to expand. Each year, more neighborhoods, villages, and towns around Valencia, encouraged by local, regional, and national tourist councils, introduce new celebrations. Flesler reports how "since the 1960s ... [the] festivals have experienced continuous growth in size, showiness, and popularity, together with a gradual increase in the number of towns celebrating them. This double expansion is directly related to the continuous development of the tourism industry in Spain" ([24], p. 98). 
their traditions were under public fire, shrouded by suspicions of prejudice. The inclusion of Moorish squadrons might "wound some sensibilities," Moreno admitted, although Ferrando emphasized that the festivals are "not ... offensive to any particular religion" despite what some observers might think. Yet, along with diffidence, a tone of melancholy resonates in their responses. And why not? They knew that something was missing. Their town's famous traditions, as displayed publicly in New York, lacked something fundamental. After all, what are the Moors and Christians celebrations without the Moors? That simple and seemingly obvious question points us back to the actual structure and content of the fiestas. The move also forces us to turn the analytical lens around. Rather than examining the socio-political context to gain insight into the festivals, we can look to the festivals to illuminate the socio-political context.

That critical turn is productive since, as it happens, the showdown between "Moors" and "Christians" in the fiestas is more complicated than it initially appears. As Daniela Flesler masterfully delineates in "Playing Guest and Host" - a key chapter on the festivals in her 2008 volume, The Return of the Moor - "an essential ambivalence" inhabits the celebrations and, in turn, that tension both expresses and produces a deep sense of unease in the fiestas and in Spanish society more broadly [24] ${ }^{21}$. In a short piece for readers of The Guardian (UK), British travel writer Andromeda Agnew picks up on a strange pattern, one that Flesler subsequently explores in greater depth. In observing a variety of Moors and Christians celebrations in Alicante province, Agnew casually notes how "the festivals give [Spaniards] a chance to revel in their Islamic ancestry." The celebrations trumpet the cultural sophistication of the Moors of Spain's past. "In contrast to the magnificent yet cumbersome armour of the Christians, the Moors float down the street, resplendent in yellow and purple chiffon. These characteristics confound her initial expectations. "Everyone wants to be a Moor!" she observes [17].

In "Playing Guest and Host," Flesler pursues this idea even further. She too underscores the point that the role-playing on which the festivals depend arises from the desire to celebrate Spain's Moorish legacy and, more immediately, to claim it as a unique and foundational component of Spanish culture and identity. However, Flesler follows her deconstructionist intuitions - already figured in the title of the essay — and argues that such assertions of identity belie uncertainties about who "belongs" in Spain and, in turn, to whom the land "belongs." Who is "guest," and who is "host"? Drawing on Jacques Derrida's and Sarah Ahmed's considerations of those categories to illuminate the roles acted out in the festivals, Flesler shows how "the efforts to delimit clear spaces of separation fail. Moors and Christians become simultaneously guests and hosts in what Homi Bhabha calls a 'third space' that is neither one of complete separation nor one of homogenization" ([24], p. 97).

In this way, Flesler looks beyond immediate appearances. As already noted in my initial description of the festivals, everything about them conveys the sense of encounter between distinct cultures. Again, to describe the celebrations in Huntington's terms, they dramatize the spectacular "clash of civilizations." As Flesler summarizes, "the true protagonist of these celebrations is the excess that permeates all the festive rituals at both the discursive and performative levels" ([24], p. 101). For, through "the rhetorical excess," the festivals present "narratives that aim at justifying

21 Flesler's chapter is based on [63], an earlier article co-written with Adrián Pérez Melgosa. 
an essential, Christian right to the land, while explaining away the presence of the Moors as something temporary and inconsequential" ([24], p. 102). From this angle, the spectacular dramatizations of local legend really speak to contemporary circumstances. Flesler explains: "The preoccupation with current changes in the racial and ethnic composition of Spanish society is displaced into a distant and safer past." Thus, "the festivals are plagued by an anxiety of delimiting, in that past, the concrete space occupied by each group, to ensure that the limits appear well-established" ([24], p. 97). The context of the festivals makes the "anxiety of delimiting" particularly acute. As noted earlier, not only was the Islamic legacy long and rich in the area of Valencia Community that serves as the heartland of the celebrations but the region also remains one of the main destinations in Spain for Muslim immigrants as well as tourists.

Furthermore, by locating the apprehension at the heart of the process of "delimiting" that the festivals attempt to enact, Flesler stresses how the efforts to establish those limits ultimately fail. The boundaries of distinction, so clearly marked in every aspect of the performance, constantly break down as the roles of Moors and Christians continually flip back and forth. As Flesler summarizes,

within the many rituals of separation between the two sides that make up the festivals, there are traces that reveal how the official discourse making the Christians as hosts is only intelligible if one notes their position as guests in that same territory. During the celebrations, each one of the groups takes turns at occupying the position of host, [serving alternately as victors and victims, possessing and losing the castle,] with an awareness of the transitory nature of this role, aware that both in the festival and in the history of the area, both Moors and Christians are guests ([24], p. 103).

Despite the spectacular mechanisms employed in the festivals to delimit roles and to distinguish "Moors" from "Christians," the collapse of those boundaries occurs not only in fleeting moments but also in obvious ways at critical junctures of the proceedings. For instance, the climax of every Moors and Christians fiesta — regardless of its length and complexity — arrives with the Christians' "reconquest," after a prolonged battle, of the territory overtaken by the Moorish invaders during the early stages of the festival. At that critical moment, the Moors leave and the Christians enter the castle (or other symbolic stronghold) on which the preceding battles focused with all of their booming retorts from life-size guns and canons. In this transposition of conqueror and conquered, the troops come into direct contact. Their leaders address each other in extended dialogue. The confrontation represents the dramatic apex of the entire festival, as the Moorish leader expresses despair at the loss and pleads for compassion. The Christians weigh the request - usually with a conflicted and laborious consideration of the facts-before finally expelling the Moors from the land.

The conclusion of the 2012 celebration in the San Blas neighborhood of Alicante offers an outstanding example ${ }^{22}$. As the Moor and Christian groups faced each other across the final "battleground" - in fact, a local intersection where organizers erected the stage-set castle - the Moors' emir emerged from among his battalions. In a long monologue presented in the rhetorical style of a medieval epic poem and directed toward the Christian leaders - the queen and her generals - standing at the head of their army, the emir acknowledged his peoples' defeat and the

22 All descriptions, images, and transcriptions of the 2012 festival in San Blas derive from materials produced by the author at the event. 
loss of their possessions (Figure 8). He felt "pitiful" and lamented his "broken soul" [alma partida] now that the Christians were forcing him and his community to leave. "Blood ties me to this land, my land!" he cried. His own blood as well as that of his family and of his people had mixed with that soil, where generations of his ancestors were buried [enterrados]. Banishment, "el destierro"- literally, "removal from the land"-felt worse than death to them, he wailed. As "exiles," the Moors would be completely ... unmoored! In turn, the emir's emotional petition moved the Christians. Holding his head in his hands, their lead general agonizes over what to do. "I feel two impulses," he cried. "I don't know ... to punish or to pardon?!" [Siento los dos impulsos. ¡No sé! ¿Condenar o perdonar?] And then, quickly finding his resolve and acting on it before it leaves him, he issued his final command: "Leave now! Take your liberty instead of death!" As the Moors marched solemnly past him and the other Christians, unmoored after all, the general recovered his conviction. "Alicante is now Christian! Glory to God!" he proclaimed. In light of the obviously conflicted emotions of the preceding action, an uncertainty echoed from the general's words. His pronouncement sounded more like a statement of possibility than of fact. Either way, he led his charges into the reclaimed castle to the rhythm of the victory march rising from the loudspeakers temporarily installed in the streets.

Figure 8. After the "reconquest," the Moor emir pleads for mercy from the Christian queen. San Blas neighborhood, Alicante city, 9 July 2012.

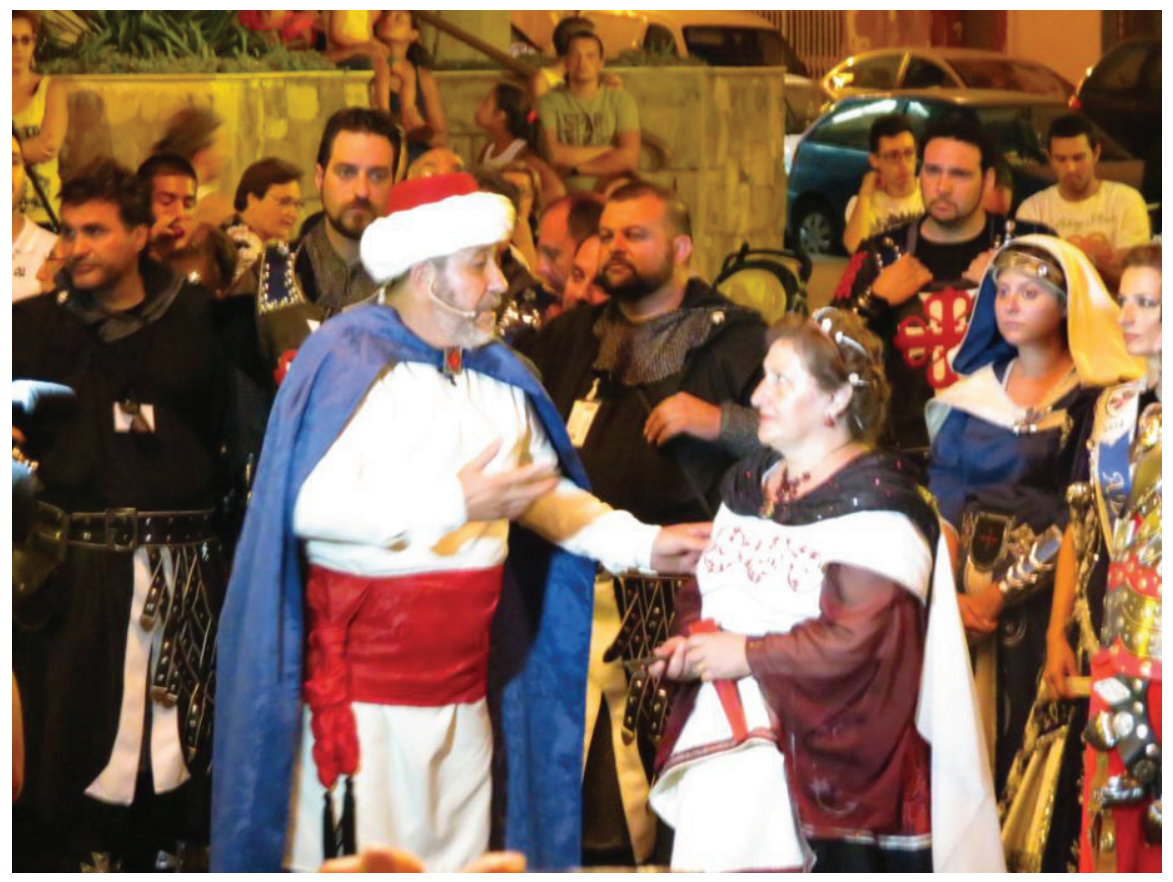

Photo by author.

While the words and details may differ from festival to festival and place to place, San Blas's 2012 iteration portrays a now-familiar scene. In almost every case, the final encounter follows the same general script: the lamentations of the Moor leader of the impending destierro, of the final unmooring from the beloved place; the conflicted emotions of the Christian figureheads; uncertainty followed by the sudden, resolute expulsion of the defeated.... Watching these dramas, with their flip-flopping roles and obvious ambivalences-highlighted through the performers' 
histrionics and only made more apparent by the Christian leaders' artificial claims to definitive victories - the questions raised by Flesler rush to the surface: Who is 'guest' here, and who is 'host'? Who "belongs" to these lands, and to whom do these lands "belong"? In the end, the "clash of civilizations" portrayed in such exaggerated terms in the festivals - the narrative of Muslim 'invaders' versus Christian 'natives' - feels more like a showdown of intimate adversaries, if not a nasty family quarrel.

In this way, the different rhetorics of the festivals - their overarching clarity countered by the palpable uncertainties - conflict. When all is said and done, the overriding carnivalesque quality of the fiestas points to the fact that the celebrations truly are carnivals, in the vein of Spain's long and abundant tradition of popular rituals: The Moors and Christians festivals provide a release from the strictures of everyday expectations, as Bernabeu Rico argues ([19], p. 99); they unsettle social roles and hierarchies, as Harris explains ([25], pp. 48, 59). And, as noted earlier, the stylized battles on the streets create "semiotic battlefields" where conflicting meanings and interpretations of audience and actors alike take shape and play out. Still, the festivals speak clearly of a popular desire to present Spain as an exemplar of "convivencia" - cultural and religious coexistence-by embracing the legacy of the Moors (and Jews and others). Yet, in order to sustain this claim-a "multiculturalism avant la lettre," as Flesler calls it ([24], p. 97) - those 'other' elements must be constrained within the controlled spaces of the medieval past or the ritual present. But as this ideal of convivencia circulates through the mock confrontations and resolutions of Moors and Christians, what other meanings and desires make their way onto the "semiotic battlefields" of the fiestas? What do tourists take from the dramas? And, more pointedly, what do they say to "the Moors" of today, including the thousands of Muslims who reside-whether as recent immigrants, long-time residents, or new converts - in the places where the celebrations occur? ${ }^{23}$.

A viable catalog of answers to those questions, much less feasible analysis of responses, falls beyond the scope of the present essay. Nevertheless, the queries pull our attention back to the primary topic at hand. The image of the Alcoy contingents in New York's Columbus Day parade comes back into view, and it is striking (see Figure 7). As the Christian squadrons march alone down Fifth Avenue, without their familiar counterparts and out of their usual context, they appear a bit like those adversaries at the conclusion of the typical fiesta back home. They appear, literally and figuratively, unmoored. As a representation of "Spanish culture"-much less of the festivals themselves - the picture is incomplete, and the glaring absence of Moors among the Alcoy procession paradoxically heightens our awareness of the overarching reality of Iberian history as well as its continual re-imaginings in cultural forms like the fiestas: The Islamic presence, whether as an enduring power from the past or as a collection of immigrants and converts in the present, remains indispensible to the idea of "Spain" as well as to social realities on the peninsula across many centuries.

In that light, the final image captures the tremendous irony of the situation. The "Christian" squadrons - the victorious "hosts" at the fiestas on home turf-suddenly find themselves as guests

23 I recognize my limited discussion in this essay of Muslims' participation in and perspectives on the fiestas and the public debates about them. Flesler addresses this issue in ([24], pp. 99-101). For a broad and illuminating consideration of Muslim viewpoints on issues of cultural representation in contemporary Spain, see [64]. 
at a celebration of a literal and figurative departure from that Spain of the "Old World" that their own festival gloriously invokes. The American parades also center around the achievements of "the Catholic Monarchs" in 1492, as do the Festivals of Moors and Christians but, rather than mark Ferdinand and Isabella's ostensible completion of "the Reconquest" with the expulsion of the Jews and the takeover of the last Islamic emirate at Granada, the Columbus Day and Hispanic Heritage festivities memorialize the "New World" that Columbus set in motion in the name of those same royal patrons. So, in the midst of commemoration of leaving behind Europe for a land of opportunity, we see the remnant from Alcoy playing the "Christian" part in an unfamiliar popular celebration serving a different national mythology. The Alcoyanos parade through the heart of one of the world's financial and cultural centers, heading southward in the direction of the statue of Lady Liberty who proudly stands in New York's harbor as a symbol of welcome and protection to all who wish to enter her territory ("Give me your tired, your poor...."). The revelry of which the "Christians" find themselves part is, like that statute, intended as a tribute to the foundational role of immigrants (whether they claim "Italian," "Hispanic" and/or other identities) in building and populating the great metropolis and the nation beyond. The whole scene makes one wonder not only whose "patrimony" is on display but also who determines, and how, exactly what counts as "patrimony" in the first place.

On that day if the Alcoy marchers had kept going, past Lady Liberty and straight across the Atlantic, they would have arrived back on Iberian soil where Spaniards continued to invoke, to reflect on, and to debate those various histories. What passed through the Alcoyanos' minds as they processed through midtown Manhattan without any "Moors," strangers in a strange land and spectacularly outfitted as the triumphant denizens of an earlier epoch? Did they too appreciate the paradoxes arising out of that odd scene, with their "squadron" surrounded on all sides by a multitude of posters and banners? The signs included inscriptions - in English, in Spanish, or more often in both idioms - of the theme of the day's celebration. The phrase provided clear indication of why the "Christians" always depended upon the "Moors" in their fiestas back home. More broadly, it offered a reminder of the underlying hybridity of Spanish as well as American cultures, despite the predominance in public discourse of rhetoric about the defining impact of distinct "civilizations." "¡Todos somos imigrantes!” the placards proclaimed. "We are all immigrants!"

\section{Acknowledgments}

Many thanks to Todd Green for initial encouragement and subsequent support of this project, first as a presentation at the 2012 Annual Meeting of the American Academy of Religion and then as a contribution to this special issue of Religions. I also greatly appreciate the generous and constructive commentary provided by the anonymous reviewers of the initial submission of this essay. Their feedback has helped to make the current version much stronger. Finally, I am deeply indebted to my wife (and resident alicantina), Nereida Segura-Rico, for many reasons, including her invaluable engagement with evolving drafts of the project. 


\section{Conflicts of Interest}

The author declares no conflicts of interest.

\section{References and Notes}

1. Gunther Dietz. "Migration and Religion in Spain." Netzwerk Migration in Europa, 2010. http://www.migrationeducation.org/45.1.html?\&rid=165\&cHash=f27da8678dd627fd7fb5e171 $335 \mathrm{cc} 5 \mathrm{c} 3$.

2. Alfonso Pérez-Agote. "Religious change in Spain." Social Compass 57 (2010): 224-34.

3. Javier Zapata de la Vega. "Marroquíes en el País Valenciano." In Atlas de la Inmigración Magrebi en España. Edited by Bernabé López García. Madrid: Universidad Autónoma de Madrid, 1996, pp. 185-90.

4. César Vidal. España Frente al Islam: De Mahoma a Ben Laden. Madrid: La Esfera de los Libros, 2004.

5. "El 'Financial Times' Destaca la 'Autocensura' en la Fiesta de Moros y Cristianos." Levante-EMV, 17 October 2006. http://www.levante-emv.com/comunitat-valenciana/2006/10/ 17/financial-times-destaca-autocensura-fiesta-moros-cristianos/239291.html.

6. Carlos Pérez. "Los Moros y Cristianos más Protegidos." Las Provincias, 14 October 2006. http://www.lasprovincias.es/prensa/20061014/cvalenciana/moros-cristianos-protegidos_ 20061014.html.

7. Unión Nacional de Entidades Festeras. “Junta de Gobierno 19 November 2006." Available online: http://www.undef.es/ (accessed on 14 November 2012).

8. Bea Navarrete. "Más de 250 Moros y Cristianos de Alcoy Desfilarán el Día de la Hispanidad por el Centro de Nueva York." Las Provincias, 2 August 2006. http://www.lasprovincias.es/ alicante/pg060802/prensa/noticias/Comarcas/200608/02/ALI-COM-028.html.

9. Press Service of UNESCO. "Unesco Issues First Ever Proclamation of Masterpieces of the Oral and Intangible Heritage.” Available online: http://www.unesco.org/bpi/eng/unescopress/ 2001/01-71e.shtml (accessed on 13 August 2013).

10. Luis Sánchez Bardón. "Living Spain: Intangible world cultural heritage.” Ronda Iberia, July 2013, 46-47, 49-50.

11. UNESCO. "Intangible Cultural Heritage." Available online: http://en.unesco.org/themes/ intangible-cultural-heritage (accessed on 13 August 2013).

12. Antonio Ariño. "La expansión del patrimonio cultural." Revista del Occidente 250 (2002): $129-50$.

13. Franciso Hernández Hernández. El Patrimonio Cultural: La Memoria Recuperada. Gijón: Trea, 2002.

14. Gil Manuel Hernández i Martí, ed. La Memoria Construida: Patrimonio Cultural y Modernidad. Valencia: Tirant lo Blanch, 2005.

15. Beatriz Santamarina Campos. "Una Aproximación al Patrimonio Cultural." In La Memoria Construida: Patrimonio Cultural y Modernidad. Edited by Gil Manuel Hernández i Martí. Valencia: Tirant lo Blanch, 2005. 
16. Beatriz Santamarina Campos. "Moros y Cristianos: De la Batalla Festiva a la Discursiva." Gazeta de Antropología, May 2008. http://www.ugr.es/ pwlac/G24_16Beatriz_Santamarina_ Campos.html.

17. Andromeda Agnew. "Spain: Religion, Costumes and Conquests_-All a Town Needs to Party." The Guardian, 6 July 2010. http://www.theguardian.com/world/2010/jul/06/letter-from-spainmoors-christians.

18. Roland Baumann. "The Moors and Christians of Válor: Folklore and Conflict in Alpujarra (Andulasia)." Ph.D. Dissertation, Tulane University, May 1995.

19. José Luis Bernabeu Rico. Significadas Sociales de las Fiestas de Moros y Cristianos. Alicante: Universidad Nacional de Educación a Distancia, 1981.

20. Louise M. Burkhart. "Aztecs, moors, and christians: Festivals of reconquest in Mexico and Spain.” American Ethnologist 29 (2002): 769-71.

21. Colin Smith. Christians and Moors in Spain. Warminster, UK: Aris \& Phillips, 1988, vol. 1.

22. María Soledad Carrasco Urgoiti. El Moro Retador y el Moro Amigo (Estudios Sobre Fiestas y Comedias de Moros y Cristianos). Granada: Universidad de Granada, 1996.

23. Henk Driessen. "Mock battles between moors and christians: Playing the confrontation of crescent with cross in Spain's South.” Ethntología Europaea 15 (1985): 105-15.

24. Daniela Flesler. "Playing Guest and Host: Moors and Christians, Moroccans and Spaniards in Historical Novels and Festive Reenactments." In The Return of the Moor: Spanish Responses to Contemporary Moroccan Immigration. West Lafayette, IN: Purdue University Press, 2008, pp. 97-129.

25. Max Harris. "Muhammad and the Virgin: Folk Dramatizations of Battles between Moors and Christians in Modern Spain." Drama Review 38 (1994): 45-61.

26. Max Harris. Aztecs, Moors, and Christians: Festivals of Reconquest in Mexico and Spain. Austin: University of Texas Press, 2000.

27. Bereber. "Entrada mora en las fiestas de Moros y Cristianos de 2006 en Campello (provincia de Alicante, España)." http://en.wikipedia.org/wiki/File:ElCampello2006.

28. Pepetps. "Desembarc Moros i Cristians La Vila Joiosa." http://commons.wikimedia.org/wiki/ File:Desembarc_Moros_i_cristians_La_Vila_Joiosa.png.

29. José Aguado. "Petrer-'La Rendició' devuelve el Castillo a los cristianos." Available online: http://fiestademorosycristianos.blogspot.com/2009/12/petrer-la-rendicio-devuelve-elcastillo.html (accessed on 8 July 2012).

30. Popezz. "Entrada de Cristianos (Alcoy, 22 de abril 2006)." http://commons.wikimedia. org/wiki/File:EntradafilaVascos2006.jpg.

31. NordNordWest. "Spain Location Map: Valencia/Alicante." http://en.wikipedia.org/wiki/ File:Spain_location_map.svg\#file.

32. Asociación de San Jorge de Alcoy. Nostra Festa. Alicante: Gráficas Ciudad, 1982.

33. Asociación de Moros y Cristianos de San Blas. "Moros y Cristianos de San Blas." Available online: http://mycsanblasalicante.es (accessed on 8 July 2012).

34. María Rosa Menocal. The Ornament of the World: How Muslims, Jews, and Christians Created a Culture of Tolerance in Medieval Spain. Boston: Little Brown, 2002. 
35. David M. Guss. The Festive State: Race, Ethnicity, and Nationalism as Cultural Performance. Berkeley: University of California Press, 2000.

36. John Tolan. "Using the Middle Ages to Construct Spanish Identity: Reconquista, Repoblación, and Convivencia in Nineteenth- and Twentieth-Century Spanish Historiography." In Historiographical Approaches to Medieval Colonization of East Central Europe: A Comparative Analysis against the Background of Other European Inter-Ethnic Colonization Processes in the Middle Ages. Edited by Jan Piskorsky. Boulder and New York: Eastern European Monographs and Columbia University Press, 2002, pp. 329-47.

37. Daniela Flesler, and Adrián Pérez Melgosa. "Marketing Convivencia: Contemporary Tourist Appropriations of Spain's Jewish Past." In Spain is (Still) Different: Tourism and Discourse in Spanish Identity. Edited by Eugenia Afinoguénova and Jaume Martí-Olivella. Lanham, MD: Lexington Books, 2008, pp. 63-84.

38. Peter Linehan. History and the Historians of Medieval Spain. Oxford and New York: Oxford Press and Clarendon Press, 1993.

39. Simon R. Doubleday, and David Coleman, eds. In In the Light of Medieval Spain: Islam, the West, and the Relevance of the Past. New York: Palgrave Macmillan, 2008.

40. Henry Kamen. Imagining Spain: Historical Myth and National Identity. New Haven: Yale University Press, 2008.

41. Roland Barthes. "The World of Wrestling." In Mythologies. New York: Hill and Wang, 1972, pp. 15-25.

42. Samuel P. Huntington. "The clash of civilizations?" Foreign Affairs 72 (1993): 22-49.

43. Samuel P. Huntington. The Clash of Civilizations and the Remaking of World Order. New York: Simon \& Schuster, 1996.

44. Jerome Socolovsky. "Muslim Cartoon Rioting Affects Spanish Rituals." NPR, 16 February 2006. http://www.npr.org/templates/story/story.php?storyId=5206890.

45. Benedict XVI. "Faith, Reason and the University: Memories and Reflections." http://www.vatican.va/holy_father/benedict_xvi/speeches/2006/september/documents/hf_benxvi_spe_20060912_university-regensburg_en.html.

46. "Pope 'Deeply Sorry' for Comments on Islam." MSNBC, 17 September 2006. http://www.nbcnews.com/id/14871562/ns/world_news-europe/t/pope-deeply-sorry-commentsislam/.

47. Hudson Institute. "Upcoming Events Detail." Available online: http://www.hudson.org/ index.cfm?fuseaction=hudson_upcoming_events\&id=301 (accessed on 13 August 2013).

48. “Aznar Defends Pope's Remarks.” Gulf News, 26 September 2006. http:/gulfnews.com/news/ world/other-world/aznar-defends-pope-s-remarks-1.256520.

49. "Former Spanish President Says Double Standard Exists between Islam and the West." Catholic News Agency, 25 September 2006. http://www.catholicnewsagency.com/news/ former_spanish_president_says_double_standard_exits_between_islam_and_the_west/.

50. “Aznar Defiende al Papa Argumentando que los Musulmanes no Piden perdón por Conquistar España.” 20 Minutos, 23 September 2006. http://www.20minutos.es/noticia/155333/0/aznar/ musulmanes/papa/. 
51. "La Junta Islámica Descalifica las Palabras de Aznar Contra la Conquista Musulmana de España.” El País Digital, 24 September 2006. http://elpais.com/diario/2006/09/24/espana/ 1159048815_850215.html.

52. United Nations Alliance of Civilizations. "The History of the UN Alliance of Civilizations Initiative, From Concept to Present Day.” Available online: http://www.unaoc.org/about/history/ (accessed on 13 November 2013).

53. United Nations Department of Public Information. "Press Release SG/SM/10004 (Secretary-General Announces Launch of 'Alliance of Civilizations' Aimed at Bridging Divides Between Societies Exploited by Extremists).” Available online: http://www.un.org/ News/Press/docs/2005/sgsm10004.doc.htm (accessed on 13 August 2013).

54. Lisa Abend. "Spain's New Muslims: A Historical Romance." In In the Light of Medieval Spain: Islam, the West, and the Relevance of the Past. Edited by Simon R. Doubleday and David Coleman. New York: Palgrave Macmillan, 2008, pp. 133-56.

55. "Musulmanes Piden Suprimir las Fiestas de Moros y Cristianos 'por no Caber en la España Democrática'." El Mundo, 5 October 2006. http://www.elmundo.es/elmundo/2006/10/05/ espana/1160050857.html.

56. "El PP pide que los Moros y Cristianos sean Patrimonio de la Humanidad." Vinalopodigital, 14 October 2006. http://vinalopodigital.net/vinalopo/modules/news/article.php?storyid=239.

57. Miguel Ramjil. "La fiesta de Moros y Cristianos de Alcoy encabezó el desfile de la Hispanidad en Nueva York." Available online: http://www.canarias7.es/articulo.cfm? Id=36648 (accessed on 10 November 2012).

58. Paco González Paz. "Las fiestas de Alcoy de Moros y Cristianos, sin 'moros', deslumbran en la Gran Manzana." Canarias7, 9 October 2006. http://www.canarias7.es/articulo.cfm? Id=36648.

59. "El PSPV apoya que la Unesco Reconozca a los Moros y Cristianos pero Critica a Zaplana. Los Socialistas Lamentan la Injerencia del PP y Solicitan que la UNDEF Lidere el Proceso." Levante-EMV, 19 October 2006. http://www.levante-emv.com/alacant/3318/presidenteconsejo-islamico-comunitat-reprueba-eliminacion-fiestas/240785.html.

60. "El PP Aprueba en Solitario Pedir a la Unesco que la Fiesta sea Patrimonio de la Humanidad. La Oposición Rechaza la Propuesta por Considerarla Precipitada y no Contar con el Casal." Levante-EMV, 28 October 2006. http://www.levante-emv.com/alacant/3324/pp-apruebasolitario-pedir-unesco-fiesta-sea-patrimonio-humanidad/242547.html.

61. Observatorio del Patrimonio Histórico Español. "Controversia en las Fiestas de Moros y Cristianos." Available online: http://www.ugr.es/ ophe/001NOTICIAS/ENLACES/ noticias002.htm (accessed on 10 November 2012).

62. Hector García. "No es un proceso sencillo y puede tardar 2 o 3 años." Levante-EMV, 8 June 2013. http://www.levante-emv.com/valencia/2013/06/08/proceso-sencillo-tardar-2-o/1005114.html.

63. Daniela Flesler, and Adrián Pérez Melgosa. "Battles of identity, or playing 'Guest' and 'Host': The festivals of moors and christians in the context of moroccan immigration in Spain." Journal of Spanish Cultural Studies 4 (2003): 151-68.

64. Eva Borreguero. "The moors are coming, the moors are coming! Encounters with muslims in contemporary Spain.” Islam and Christian-Muslim Relations 17 (2006): 417-32. 


\title{
New Labour and the Re-making of British Islam: The Case of the Radical Middle Way and the "Reclamation" of the Classical Islamic Tradition
}

\author{
Stephen H. Jones
}

\begin{abstract}
This article examines the emergence of new forms of Islam in Britain between the 1990s and the present, and in particular the role played by the New Labour government (1997-2010) in encouraging new expressions of Islam. It charts the development of the Islamic tradition in Britain between the migration of mainly South Asian Muslims in the 1950s and 1960s and the Rushdie affair in the late 1980s, before outlining some of the challenges Muslims in Britain have faced transmitting Islamic traditions in a stable state to younger generations. Against the backdrop of increasing public concern about an inter-generational divide among Muslims and its supposed role in allowing radicalism to flourish, the article explores recent attempts to develop and promote forms of Islam that are "authentically British" and that challenge radical perspectives. Using the case study of the Radical Middle Way initiative, it looks into the uneasy relationship between these newer forms of Islam and the supportive New Labour administration, highlighting weaknesses in literature that focuses on the 'disciplining' of Muslims. Finally, it explains how the concept of classical Islamic tradition is utilised in creative ways not anticipated or engaged with by advocates of the "clash of civilisations" thesis.
\end{abstract}

Reprinted from Religions. Cite as: Jones, S.H. "New Labour and the Re-making of British Islam: The Case of the Radical Middle Way and the "Reclamation" of the Classical Islamic Tradition." Religions 4 (2013): 550-566.

\section{Abbreviations}

RMW: Radical Middle Way; MCB: Muslim Council of Britain.

\section{Introduction}

"In the realm of the political", Kwame Anthony Appiah has remarked, "theories have a habit of becoming part of what they theorize" ([1], p. x). For no recent political theory has this comment seemed more apt than Samuel Huntington's (in)famous "clash of civilizations" thesis, which is notable today not for its analytical power so much as the role it has played in shaping the West's perception of itself and of recent world events [2]. The conservative philosopher Roger Scruton has proposed that Huntington's hypothesis "has more credibility today that it had in 1993" ([3], p. vi), 
when it was first published in Foreign Affairs [4]. In one sense, this claim seems to be entirely wrong. The analysis that Huntington offered - in particular his suggestion that there exists today a coherent cultural entity called "Islamic civilization"- has been repeatedly shown to be incorrect. Roy and others have demonstrated that traditional Muslim cultural formations and forms of knowledge production have been undermined by colonialism and globalization, and that many radical forms of Islam have been influenced by the militant Left [5-8]. Yet at the same time it is hard to deny Scruton has a point. Huntington's position is certainly now more widely believed, in part because his theory has had a performative effect, helping to make into a reality the very clash it predicted.

Of course, Huntington's book is not the sole cause of the widespread perception that the "Islamic world" and the "Western world" are two separate and incompatible cultural entities, and that episodes such as the 2001 attacks on the Twin Towers are best understood as the consequences of those entities colliding, like two tectonic plates; he can perhaps, as Roy has argued, be seen as a symptom as much as a cause ([5], p. 9). Yet his writing is certainly the most influential of a family of narratives about the West made by academic researchers, historians, media commentators and political figures. (In the UK, the current Secretary of State for Education, Michael Gove, takes a view not far from Huntington's [9].) The most incendiary of these narratives, such as those by the author Bruce Bawer and the journalist Melanie Phillips, have tended to focus on Muslim immigration [10,11]. The argument in these cases has been that, as Muslims have moved in large numbers to European nations, they have gradually weakened the West's once-strong cultural foundations.

In this article I also focus on Muslim migration to Europe - and Britain specifically — though my analysis and conclusions are quite different. I offer an account of the development of the Islamic tradition in Britain, beginning with the migration of mainly South Asian Muslims in the 1950s and 1960s and focusing on new expressions of Islam that came to prominence under the New Labour government between 1997 and 2010. In doing this, my aim is not to offer a Panglossian account of the migration of Muslims to the UK in contrast to the pessimism of Huntington and his supporters. On the contrary, I highlight the significant challenges that Muslims in Britain have faced transmitting Islam in a coherent form to younger generations, as well as the profound tensions engendered by New Labour's policies toward Muslims and radicalization. However, I do focus on an organisation that presents an ironic challenge to Huntington's thesis. Central to Huntington's hypothesis is the idea that Islam and the West are culturally distinct, the latter being based on modern and secular ideas and the former being rooted in pre-Enlightenment traditions. In what follows, though, I show how new initiatives in Britain have sought to bypass imported South Asian forms of Islam, counter "youthful radicalism" and facilitate the Islamic tradition's cultural and political integration within British society precisely by “reclaiming” Islam's traditional classical heritage.

The analysis in this article is based upon research carried out between 2008 and 2010 which comprised a combination of 15 interviews with Muslim intellectuals, activists and religious scholars and observation of and regular participation in events held by three London-based Muslim organizations - of which one, the Radical Middle Way, is the focus here. After a first section in which I give a (necessarily brief) description of the process of Muslim migration and community formation in the UK, I describe the policy context that led to the Radical Middle Way being formed 
and coming to prominence, aided by government. The involvement of New Labour in a bewilderingly wide range of Muslim organisation caused, for good reason, significant controversy and has attracted significant criticism from academic researchers. While agreeing with much of this criticism, in describing the emergence of Radical Middle Way I try to point to areas of neglect, specifically the agency of Muslim intellectuals in the process of Islamic knowledge production.

\section{The Making of Islam in Britain}

Opposition of Huntington's thesis have often highlighted how, contrary to popular perception, Islam is not a new feature in the UK or, more broadly, in the West. Saeed, for example, has observed that rather than it being "a recent phenomenon mostly of the twentieth century, Islam, from its inception in the seventh century CE, has been part of the Christian West and the western psyche" ([12], p. 201). On a level, this opposition is well founded. As far back as $1641 \mathrm{CE}$ documents can be found referring to sects existing in London "with a certaine foolish beliefe of Mahomet" ([13], p. 27). There are even records of the powerful Anglo-Saxon king Offa of Mercia, who died in 796, having coins minted that had the shahada inscribed in Arabic on one side ([14], pp. 6-7). Nevertheless, it is only in the last fifty to one-hundred years that a significant minority of Muslims has settled in Britain - as well as a number of other European nation-states - permanently. In 1951 there were just 21,000 Muslims in the UK, which at the time accounted for around 0.05 per cent of the country's population ([15], p. 19). In 2001 there were 1.6 million (2.7 per cent of the total), with the figure increasing still further by the time of the 2011 Census to 2.7 million (4.8 per cent of the total).

The first large-scale migration to the UK by Muslims occurred around the time of the First World War after the fighting on the European Continent resulted in huge demand for labourers to replace soldiers abroad. Muslim seamen from the British colonies were attracted to port towns in the UK such as Cardiff, Newport and South Shields ([13], pp. 40-45 and 97). These Muslim communities, which were treated terribly following the war's end, were however small compared to those that emerged in the 1950s and 1960s following the migration of Muslim workers from (now former) British colonial territories. Migration to Britain in the mid-twentieth century was prompted by both "pull factors" (the chance to escape poverty) and "push factors" (the partitioning of India and "Africanization" policies in countries such as Kenya and Uganda). Though of diverse origins, the overwhelming majority of migrants came from what are now India, Pakistan and Bangladesh; even today, despite considerable recent diversification of the British Muslim population, 60 per cent of the UK's Muslims originate from these countries. Migration from these contexts tended to take the form of a "chain", with initial "pioneers" from South Asia being later joined first by their immediate family, and then in many cases by members of extended kinship networks.

According to Ansari, prior to the 1950s modernist forms of Islam were in the ascendant in the UK. The Muslim port communities in Cardiff and South Shields were fairly insubstantial and slow to establish religious institutions. The main Islamic centres were places such as Liverpool, where for a while there was a Muslim collective active in the public domain led by the prominent convert William Abdullah Quilliam, and Woking, where members of the Pan-Islamic Society ran a successful mission from the small but ornate Shah Jahan Mosque. Recognising that to make Islam appealing to a British audience it would need to be presented in a familiar form, these groups wrote 
in English, drew parallels with Christianity and challenged traditional Islamic position regarding the seclusion of women and punishments for "apostates" ([13], pp. 130-33). Members of the Pan-Islamic Society in London also distilled the hadith volumes into short books with the aim of correcting misconceptions about the faith (see for example [17]).

Most of the migrants that journeyed to the UK from South Asia in the 1960s came, as Lewis observes, from "rural contexts where Islam was part of the rhythm of life" ([15], p. xvii). They were thus unfamiliar with this modernist movement. Upon migrating many had little intention of making the UK their permanent home, but as the dream of one day returning to their country of birth began to fade they started to construct institutions and communities that would enable them to practice the Islamic tradition with which they were familiar as best they could and help them preserve that tradition for future generations. Efforts were made to import distinctive Islamic traditions into the UK (sometimes literally, with religious leaders being brought in from overseas) and slowly from the 1960s through into the 1970s and '80s these forms of Islam became dominant. Mosques and madrasas were set up which inevitably reflected the particular linguistic and doctrinal character of their founders ([13], pp. 342-43; [18], pp. 56-58). Indeed, the creation of these institutions following migration led to Muslim migrants separating into groups, as Ansari explains:

Segregation [between different Muslim groups followed chain migration], and previously ethnically mixed Muslim communities increasingly fragmented according to village-kinship, tribal, ethnic and sectarian affiliation. Indians, Yemenis and Turkish Cypriots who had lived together in boarding houses during and after the Second World War, sharing more or less the same religious facilities, gradually separated to form ethnic settlements that then established their own distinct institutions. Mosques and religious schools also reflected this process of segmentation, and imported religious functionaries reminded Muslims of their traditional values and reinforced conformity to embedded practices ([13], p. 343).

These new communities, in which religious, ethnic and cultural identification were all tied into one another, were semi-autonomous, often providing support networks for their members. They remained aloof from British society to an extent (for details see [13], p. 213), making few demands and entering into political debates rarely. When Muslims did enter into political debates it was generally to secure accommodations from government, most successfully in education. During the 1970s numerous efforts were made to change education policy, primarily to facilitate the smooth transition of Islamic traditions. For many, this meant protecting younger Muslims from "undesirable" influences in British society, with requests being made for the expansion of same-sex schools, or schools with a specific confessional ethos (see [13], pp. 309-17).

Because the ancestry of the British Muslim population is extremely complicated, it is impossibly difficult to describe all the different varieties of Islam that emerged in the UK following the post-World War II period of migration. There are, however, two strands of the Islamic tradition that have been particularly influential due to the fact that they predominate in the South Asian context: the Barelwi and Deobandi movements. Both of these emerged in the 1850s during the period of British colonial rule in India. The former is the largest in Britain, followed by the latter. Barelwis follow a form of Sufi-inspired devotional Islam which was consolidated in Bareilly in northern India, after which the tradition is named. Cities such as Bradford have large Barelwi communities, with fifteen of the thirty-four mosques that were based there during the late 1980s being linked to 
the tradition ([13], pp. 346-47; [19], pp. 118-19). The Deobandi movement is historically based on the teachings of the Dar al-Ulum Deoband in India, which was founded in the 1860s by a group of 'ulama who were committed to preserving Islamic scholarship and learning at a time when the influence of the British and Christian elite was growing ([18], pp. 36-38; [20], p. 183). This movement has tended to subvert classical scholarship by insisting that Islamic norms must be linked to scriptural proofs found in the Qur'an and collections of hadith ([13], p. 347; [20], p. 188). Although literalistic in some respects, in contrast to politicized Islamic movements such as the Jamaat-i-Islami, the Deobandi movement has generally been apolitical or even anti-political ([15], pp. 93-103; [20], pp. 183-94). In the UK this anti-political trend has become predominant, partly due to the outreach movement Tablighi Jama'at, which has its European headquarters in Dewsbury. The Deobandi movement is particularly strong in Leicester and Birmingham, and has been successful in establishing a network of dar al-ulums across the UK, with a main centre of learning located in Bury ([15], p. 89; [20], p. 187).

\section{A Crisis in Transmission?}

Muslim migrants to Britain have faced considerable barriers when they have tried to establish community infrastructure - such as, for example, local authorities needlessly obstructing planning applications for religious buildings [21]. Their success in doing so is therefore impressive for a range of reasons - even if, as this I will discuss shortly, the existence of semi-autonomous ethno-religious communities in the UK has recently been singled out by policy-makers as a problem. However, what has become apparent in recent decades has been the profound difficulties the Muslim groups that emerged in the UK in the 1970s have had maintaining their interpretations of Islam in a stable state over time. Lewis for example has observed that "many parents and religious leaders, imported into Britain's mosques from the [South Asian] religio-cultural world, are often at a loss to help their children answer questions about Islam posed by school friends, teachers or youth workers." They are, he suggests, unable to provide Islamic teachings that "can connect with [the] lived experience [of] British Muslims whose first language is English" ([15], p. xvii).

An insight into these problems can be gained by looking at the content of the curriculum taught in some of the Deobandi dar al-ulums in Britain. Research into these institutions has indicated that, at least until relatively recently, they worked from an attenuated version of the religious education syllabus developed in Lucknow known as dars-i-nizami, which was itself inherited from eighteenth-century Farangi Mahall scholars. The educational system developed by these earlier scholars was rich, covering elements of Persian literature, logic and mathematics. Yet for reasons outlined earlier, these elements were marginalized by the Deobandis in favour of renewed emphasis on the Qur'an and hadith and the preservation of the core "Islamic sciences" (that is, methods of exegesis and the formulation of legal opinions) ([18], pp. 36-38). This is reflected in the British institutions, where the curriculum has focused on the study of textual commentaries, usually on matters of law and hadith. Students are required to translate the Qur'an and hadith collections from Arabic into Urdu, and are asked to show an awareness of key texts and commentaries. They may be encouraged to ask questions of clarification, but not of substance. Teaching itself is often in Urdu, although with a minimal English curriculum taught in the afternoon in order to conform to English law ([15], p. 100; [20], p. 188; [22], pp. 65-66). 
The problem with this that various researchers - and indeed some Muslim religious leaders (see the quotes in [23], pp. 15-16) - have identified is that it lacks much by way of a relationship to the distinct history and character of the UK. The centres produce new religious leaders yet, as Gilliat-Ray has noted, "what is striking is the absence of subjects that might help graduates engage with British Muslim youth, and the society in which they are based" ([22], p. 66). The situation in mosques appears to be similar. One study, which surveyed five-hundred of the UK's fifteen-hundred or so mosques, indicated that 44 percent of mosques do not include English in their Friday sermons, preferring instead Punjabi, Bengali or Guajarati ([23], p. 14). Figures from the British Foreign Office also indicate that large numbers of imams are still imported to serve in places of worship ([15], p. 94), meaning that perhaps 90 percent receive their religious formation abroad ([23], p. 14). Women appear also to be for the most part excluded from these places of worship: just 46 per cent have prayer facilities for women, and rarely can women speak with an imam ([23], pp. 19-20).

On its own, it is unlikely that this issue would have attracted the interest of policy-makers and political commentators. However, since the Rushdie affair in the late 1980s, and particularly since the turn of the century, the isolation of Muslim communities and the tension between younger and older generations has been singled out as one of the causes of a number of violent episodes. For example, efforts to maintain stable Muslim communities came to be identified as one of the major barriers to "community cohesion", which in turn was singled out as a major contributing factor to a series of riots in Oldham, Burnley and Bradford in the North of England in 2001 [24]. This led to renewed emphasis in UK social policy on the need to foster mixing between religious groups and identification with the British nation (as well as, critics have persuasively argued, less emphasis being placed upon economic deprivation and prejudice against minorities [25]).

More significantly, challenges in transmitting Islamic traditions to the younger generation have come to be linked with events such as the London bombings of July 2005. With young, Englishspeaking Muslim men and women who hold their religious faith to be of fundamental importance being, supposedly, badly served the older, foreign-born individuals who retain control over the majority of mosques, young Muslim have turned to other outlets for their religious guidance ([26], pp. 124-25). Concern has arisen because, in a few cases, young Muslims' frustration with their parents' faith has resulted in a search that leads ultimately to the adoption of a literalistic and intolerant form of Islam ([5], pp. 257-65). For some, radical parties have, as one former member of the revivalist movement Hizb ut-Tahrir has observes, "fill[ed] a void for the young intellectually frustrated youth who had been told that Islam is the truth and they must pray and fast by people who couldn't explain why" ([15], p. 138). The account of Hassan Saleemi, another ex-Hizb ut-Tahrir member now working on the Islam Channel, is illustrative of this tendency:

At eighteen - with the unearthing of Public Enemy, who were talking about "fight the power," imperialism and slavery-I was unhappy with Pakistani Asian culture, I was unhappy with British culture and I was not happy with the sectarianism in my local mosque. I felt alienated from Muslims and I had some grounding in colonialism. I had a history GCSE and was doing a history A-level as well, so I knew a bit about colonialism.... And [then] there was a tall white guy outside my mosque [who was a representative of Hizb ut-Tahrir] talking about Bosnia and Kashmir, and giving out leaflets, and the fact that he was white struck me. I attended the talk, and you could say the rest is history [27]. 
The emergence of such viewpoints and their apparent link to movements that have inspired militant protest and violence led to the widespread problematization of what has been termed the "subculture" of mosques and madrassahs. Between 2005 and 2010 in particular it became common to see views such as the following from Paul Goodman, the former Conservative Shadow Minister for Communities and Local Government (who withdrew from British politics following the 2010 general election), expressed among policy-makers:

The consensus about how to combat violent extremism can be summed up in three words: reform the mosques. British mosques and madrassahs - the argument runs - are dominated by elderly men from abroad who don't speak English and have limited means of communication with the younger generation. This leaves young British Muslims vulnerable to exploitative English-speaking al-Qa'eda operatives. The solution to this seems obvious: open up the mosques. Bring in young, English-speaking people to run them. Sweep away the old-fashioned assumptions, and empower Muslim women. Above all, monitor the masjids and madrassahs. Inspect them, regulate them, control them and subject them to the blizzard of best practice and quality standards guidance that's done so much for local government [28].

\section{New Labour and the "Remaking" of Islam in Britain}

Goodman above does not, in fact, just express a widely held opinion, but provides a summary of what, in the wake of the 2005 London bombings, became official policy in the New Labour government. The Labour Party has traditionally attracted a disproportionate number of the votes of ethnic minorities in Britain, and has a long and complex history of forming partnerships with ethnic minority associations. Upon coming to power in 1997 New Labour formed a close relationship with the recently formed Muslim Council of Britain (MCB), a group that had been developed ostensibly in order to allow Muslims to speak, politically, with "one voice". This relationship remained close for a little under a decade, and was marked by efforts to secure various gains for Muslims in Britain including, inter alia, strengthened religious discrimination legislation and the addition of a question about religious identity in the decennial national census. Following the London bombings, however, this relationship broke down and the character of New Labour's engagement altered.

Firstly, under considerable pressure from a rapidly proliferating array of Muslim representative bodies and a growing body of critics on both sides of the political spectrum, who viewed the MCB as dominated by conservative male elders (and in some cases dangerous "Islamists"), New Labour sought out new partners such as Quilliam and the Sufi Muslim Council (for details see [29,30]). Secondly, under pressure to develop a response to the extremist perspectives that the London bombers espoused, the party started to adopt a more direct (or even invasive) approach to Islam in Britain. Islamic knowledge was not something that often entered into the political arena in the 1990s and early 2000s when New Labour engaged with the MCB regularly. Indeed, the MCB has never sought to represent Islam but rather "British citizens with an Islamic heritage", implying the full range of Muslims, from the devoutly religious to those who do not identify with any theological vision [31]. Yet in this new environment religious knowledge became an issue, with the UK government endeavouring to influence the production and dissemination of Islamic knowledge. 
This shift happened following the development by New Labour of the "Prevent" (known also as "Preventing Violent Extremism", or PVE) agenda [32,33]. Announced in February 2007 by Ruth Kelly, the then Secretary for Communities and Local Government, the agenda's conscious aim was to develop a "British version of Islam" ([34], p. 11). This mirrored the remarks of Nicolas Sarkozy in France, who has favoured a more "corporatist" approach to state engagement with Muslims ([35], p. 182) and who has stated on various occasions that what he would like to see is an "Islam de France" rather than "en France" ([36], p. 71). At the time of its launch, five-million pounds were dedicated to Prevent, money to be spent training foreign-born imams and, Kelly said, inducing a "step-change in the role of madrasahs in teaching about citizenship" ([34], p. 11).

From there, the strategy progressed rapidly: in 2008/2009 one-hundred and forty million pounds were earmarked for Prevent-related community initiatives ([37], p. 10). The funding of Muslim groups increased and at the same time broadened. Prevent money was offered to a bewildering array of community initiatives, some very different to the others. The Preventing Violent Extremism Community Leadership Fund funded organizations such as, in 2007/2008: the Muslim Youth Helpline $(£ 35,000)$; Khayaal Theatre Company $(£ 38,450)$; the Muslim Youth Development Partnership (£40,000); the Sufi Muslim Council $(£ 58,500)$; the Luqman Institute of Education and Development $(£ 30,000)$; and the Fatima Women’s Network $(£ 10,000)$. At the same time, pots like the Community Leadership Fund were made available to groups such as the British Muslim Forum, British Muslims for Secular Democracy, and the Mosques and Imams National Advisory Board (MINAB), which received just over $£ 75,000$. Money was also targeted at Muslim women’s projects such as the Muslim Women's Network with the aim of “enabling [women's] voices to be heard and empowering them to engage with Muslims at risk of being targeted by violent extremists" [38].

At a rhetorical level and in decisions about the allocation of public funding, the interpretation of Islam became more salient. Ministers such as Kelly began to quote Muslim intellectuals such as Tariq Ramadan, suggesting that they offer a vision for a fully integrated British Islam [34]. Islamic Studies was named by the Labour Government as a "strategically important subject" in 2007 ([39], p. 4; [40]). This was also supported by government-sponsored university-based initiatives such as "Contextualising Islam in Britain", a project funded by the Department for Communities and Local Government and based at the University of Cambridge whose main aim was to allow Muslims to come together to discuss what it means to faithfully live as a Muslim in modern Britain. This project did not shy away from theology, covering Islamic conceptions of justice, the objectives (maqasid) of Islamic law, and the nature of divine sovereignty. Funds were made available to train imams [42-44], and partnerships between Islamic centres of higher learning and universities were considered [45]. Finally, New Labour funded organizations involved in the dissemination of Islamic knowledge through "tours" of religious scholars and through on-line videos and podcasts. One of these organizations I shall concentrate on in the remaining sections: The Radical Middle Way. 


\section{Reclaiming the Centre Ground: The Case of Radical Middle Way}

The Radical Middle Way (RMW) is an initiative that grew out of the Muslim magazine $Q$-News, which was established in the early 1990s and continued until 2006. In its heyday, Q-News had a readership of 60,000 people per month, comprising mainly second and third generation British-born Muslims as well as non-Muslim religious educators and policymakers. Justly regarded by commentators as an energetic and innovative publication ([14], p. 236-38), Q-News tended to treat established Muslim representative bodies with a degree of scepticism; the magazine characterised the MCB at one point as "lassi Islamists" (a South Asian variant on the derogatory characterization of leftist groups as "champagne socialists" [31]). As Fozia Bora, one of the magazine's contributing editors, notes, "Q-News was jaded with all these institutions and made it clear that these organizations were not representative in any way because they didn't represent" (interview, 6 March 2012). Notably, though, the magazine was respectful of Islamic scholarship, and included a regular series on "questions and answers about Islam" by prominent religious scholars [46].

In its early days, $Q$-News struggled to attract the attention and support of public bodies. In fact, this lack of support was the reason behind the magazine's name. According to the founding editor of Q-News and RMW's founder, Fuad Nahdi, faith-based publications in the early 1990s were not able to attract advertising revenue from public equalities bodies, which tended to focus on relations between groups defined by "race" and ethnicity. $Q$-News did not wish to align itself with any ethnic group but needed this advertising revenue to survive, and so a "non-religious" name was adopted ([29], p. 31). By the time the magazine published its final issue in 2006 after RMW was launched, this situation had changed entirely. Public funding for religious groups, especially Muslim groups, was readily available for cohesion, capacity building and preventing extremism projects. Thus in the second half of the 2000s RMW received considerable public support—for example, $£ 350,000$ in 2009 from the Department of Communities and Local Government [38].

RMW has thus been since its inception firmly entangled in New Labour's efforts to re-make the Islamic tradition in Britain, even if it has never been funded by Prevent monies directly. It is important, though, to treat this issue with care. Academic analysis has tended to see the policies of the UK government toward British Muslims as characterized by a range of strategies and policy mechanisms designed to contain dissent, discipline (or "securitize") Muslim communities and "domesticate" Islam [37,47,48]. Neo-Foucauldian writings on governmentality (see [49]) have had considerable influence [50]. The focus in research has, in general, been on the discourses and conduct of government: for example, New Labour's tendency to frame Muslims as "good" and "bad" or "moderate" and "extremist" [48,51]; or the characterisation of Muslim women as "wives and mothers" capable of mollifying "combative masculine" forms of Islam [52]. This body of criticism has made a number of forceful points. Among other things, it has drawn attention to the way in which New Labour effectively placed the burden of the 7/7 bombings on contemporary Islam and British Muslim communities, rather than addressing any deeper sociological or political tensions. It has highlighted how New Labour policy was developed in such a way that reinforced regressive gender roles, even as New Labour sought to open up mosques to Muslim women [52].

Nevertheless, this overriding focus on the discourses and conduct of government has left relatively little room to examine the production of Islamic knowledge. As Sunier explains: 
The emphasis on governance, national identity politics, and integration and security in the study of Islam in Europe ... often conceals and ignores certain issues and trends among Muslims in Europe that are very important. This has produced a paradoxical situation. Whereas Islam has become the common denominator for a wide range of phenomena, attitudes and developments, as fields of research, religious practices and the production of religious knowledge among Muslims have suffered from programmatic concealment and downright neglect [53].

A side-effect of this has been a tendency to neglect of the practical uses of Prevent and other funding, which in turn has led to the creative agency of individuals involved in project delivery being downplayed. As the disciplinary role of the state is emphasised, critics can often imply that the forms of Islam that find favour with government are state creations certified by government and "imposed" on Muslims from above through various policy programs. The case of RMW indicates, however, that the situation is more complex than this. Certainly, the change from the early days of Q-News to the launch of RMW in 2006 was profound, and involved an at times uncomfortable move among the staff of the two organizations from being "poachers" to being "gamekeepers". In the period during which RMW received large amounts of public funding RMW had to make, as Abdul-Rehman Malik, who works for RMW and who wrote for $Q$-News, acknowledges, "a big trade-off in terms of fighting for credibility and fighting for the money to operate" (interview, 26 August 2008). One of RMW's most prominent speakers observes that by taking public funding organisations such as RMW risk being "generically discredited" because "everyone assumes that point of view is being pushed for political reasons by the same politicians that support Israel and smashed up Iraq" (interview, 27 August 2008). Yet there is continuity in the positions argued by the people behind both the organizations. There is a distinctive approach and a reliance upon specific forms of scholarship that has remained consistent and that has built up a following over more than two decades.

Throughout, $Q$-News and RMW have drawn on a distinctive range of Islamic scholars from the UK (such as Abdal-Hakim Murad, Zaki Badawi and Hasan Le Gai Eaton), Muslim-majority countries (Abdallah Bin Bayyah from Mauritania and Ali Gomaa from Egypt) and the US and Canada (Suhaib Webb, Hamza Yusuf and Ingrid Mattson). Scholars from the US have been particularly notable. (The links between British and American Islam have not been subject to much scrutiny: it is an area in need of further research.) All of these individuals have one thing in common: they have scholarly qualifications-usually from both Islamic seminaries and conventional universities (indeed many are religious teachers and university professors) - but they are not "conventional" mosque leaders. They differ from dominant South Asian forms of Islam and are consciously opposed to Salafism of the kind that influences the youthful revivalisms described earlier in this chapter. This dual break was crucial to $Q$-News's success and is even more central to RMW.

Between 2006 and 2010 RMW's activities were concentrated on "tours" of scholars around the UK, London, Birmingham and Bradford being a particular focus. These were highly popular: in February 2003 the American 'alim Hamza Yusuf, founder of the Zaytuna Institute in California, drew an audience of between four- and five-thousand when he arrived in England to speak at a mosque in Bradford - a huge audience given that the talk took place in a city of around 300,000 people, of whom around 16.1 per cent are Muslim [15]. Consistently across these tours radical 
revivalism is treated with scepticism. On occasion, it is treated to a form of sociological examination, as in the following excerpt from a talk given in London by the charismatic American preacher Suhaib Webb:

[We need to understand], in the spirit of Ibn Khaldun, ${ }^{1}$ the sociological reality of the Western Muslim. We come from the DMX madhhab. ${ }^{2}$ We come from Star Wars. We come from professional wrestling. We come from Bruce Lee. We come from a misogynistic reality that dominates women, in hip hop music.... And you give this religion to someone who comes from that background and what type of mentality is he going to have to his fellow brothers and sisters? He is Luke and Obi-Wan vs. Darth Vader.... [T] he social constructs that we live [with] in the West are those of domination. We seek to dominate others - and then we're given a group mentality that transforms itself into attacking fellow Muslims.... [S]o Hulk Hogan and Andre the Giant now know about Ibn Taymiyya and Ibn Arabi, ${ }^{3}$ and they're going to take it to the masjid and battle each other! Go on-line and look at our forums about how we talk about scholars and individuals, how we talk about each other - the hatred, the spite. Why? DMX mentality [54].

More regularly, though, opposition to such forms of Islam is rooted in emphasis on the authoritative role of Islamic traditions of scholarship. Its outlook has been heavily influenced by, in Malik's words, "Western Muslims who [are] reclaiming the classical tradition" (interview, 26 August 2008). The following two excerpts are among the clearest examples of this. The first comes from a talk on extremism by the American Muslim Umar Abd Allah, who has taught in Jeddah and the United States. This talk was delivered at Birmingham Central Mosque in 2006:

Extremism often expresses itself in a personal quest for immediately accessible knowledge.... And often this is in defiance of authority; I mean by that in defiance of traditional authority, of the schools, the tradition, the teachers. As one of the great scholars that I used to know in Morocco used to say, who was a great muhaddith, he would say: "I studied hadith all my life; I studied Islam all my life, and a young man who doesn't even pray goes into the movie theatre, comes out, buys a pamphlet, and the next day he's calling me a kaffir".... The religiosity of extremism is often based upon personal experience, and not legacy [55].

The second comes from the British Muslim convert Abdal-Hakim Murad (a.k.a. Tim Winter). Murad is one of British Islam's most prominent intellectuals. He teaches at Cambridge University, though he is also an imam as well as one of the founders of the Cambridge Muslim College, a recently established educational institution that seeks to enable religiously trained imams to engage successfully with British society. The following was delivered at a talk in London in 2005:

[The Islamic tradition is in need of] renewal, every Muslim accepts that. The religion has become old, doddery, cantankerous. The sole source of renewal is that which was good for the earliest generations of this Umma; that's established, nobody will deny it. But the difference between 'alim the and the amateur

1 Ibn Khaldun (1332-1406) was a philosopher sometimes characterized as a sociologist avant la lettre on account of his work mapping the character of different societies.

2 DMX is a popular US-based hip-hop artist.

3 Ibn Taymiyya (1263-1328) was a significant Sunni Muslim jurist and Ibn Arabi (1165-1240) was a theologian and philosopher influential in Sufism. 
is that the 'alim says we'll deal with the tree as it is, we keep it going; alhamdulillah we still have it and over the years it has acquired a certain magnificence, that in itself has the right to be respected and enjoyed. The amateur scholar says, "No, the best thing is to cut it down and we'll be back in 1453 again, or indeed back at the time of the Hijra, in the time of the Prophet, sallallahu alaihi wa sallam". This is really what is at stake. We have a tree that is more intact than the trees of the other [major religious traditions]; but we have, given the nature of the age, an increasing proliferation of people who misunderstand it, who are not grateful for it, who can't see its current beauty, who have not trained with those who have been looking after it, and think that the solution is actually to cut it down. The great calamity in our age is not that Islam needs a Reformation or that we need a liberal Islam; the great calamity is that we are not being true to our own traditions of scholarship [56].

The normative emphasis placed upon authority in these passages is easily misinterpreted. It is important to remember that RMW is not a traditional institution at which students spend years studying the intricacies of figh. For the most part, its activities remain distinct from mosques and formal educational institutions, and events are usually held in secular spaces. The Internet is a central medium for the dissemination of information, and browsers can dip into and out of the different sermons and teachings that are provided. Moreover, alongside these scholar-focused events RMW has organized events involving music and forms of cultural expression that are more conventionally associated with the 16 to 30 year olds who make up the majority of the audience at most of RMW's meetings. Rather than simply stressing the importance of maintaining existing tradition, this emphasis on classical scholarship and a legacy that stretches back hundreds of years becomes a way of reworking the Islamic tradition within the context of contemporary Britain.

It is important to note, too, that the scholars and preachers involved in RMW stress the possibility, indeed the necessity, of embedding Islam in British traditions and cultural forms. This indeed is the main point on which the RMW's founders and New Labour agreed. Murad for example, stresses the point that classical fiqh traditionally recognised local laws and customs ('urf) if they did not directly conflict with Islamic teachings. "Islam, as a universal religion, in fact as the only legitimately universal religion," Murad notes, "also makes room for the particularities of the peoples who come into it" [57]. The Cambridge-based imam has even edited a book of Muslim songs of the British Isles, taking traditional British folk songs and fusing them with Islamic themes [58]. Classical tradition and Westernization are portrayed as proceeding hand-in-hand.

The fact that RMW is not a traditional Islamic educational institution makes it difficult to evaluate its impact on the behaviour and thinking of British Muslims, and ultimately its success in reconnecting the Islamic tradition with British cultural forms. The organisation produces what Roy ([5], p. 7) terms "floating discourses"- one-off sermons and podcasts whose physical effects are difficult to trace. We do know that during the period it received large amounts of funding the organisation was very popular, with an estimated 70,000 people attending the organisation's events prior to 2009 [60], but it is hard to be clear about RMW's direct role in the creation of new institutions or community movements. Whatever its immediate impact, RMW's capacity was reduced substantially following a 2010 general election, which saw New Labour replaced by a Liberal-Conservative coalition. RMW had a number of supporters in Parliament and, unlike the $\mathrm{MCB}$, maintained cordial relations with government. While its support by the state prompted some criticism, its patronage was never as controversial among British Muslims as that of Quilliam, a 
'counter-extremism think tank' openly supportive of Prevent. Yet despite this RMW's funding fell victim to the coalition's austerity programme, with Conservatives in particular arguing that as the organisation did not engage consistently with the problem of militant religious extremism its continued funding could not be justified.

Nevertheless, when considering both the impact of RMW and its rise and fall in the eyes of government it is helpful to keep in mind that it, as I have been arguing, forms one part of a wider network of organisations and individuals whose history can be traced back to at least the 1990s and that remain active in Muslim civil society. Its aim of reworking Islamic scholarship is shared by a number of other British Muslim educational organisations (some of which have direct links to RMW), such as Maslaha, the An-Nisa Society the Cambridge Muslim College, the Muslim College and Campusalam. These groups together are illustrative of a longer term civil society response to sociological changes within the British Muslim population that is still being gradually worked out and that, while certainly affected by government policy, is not reducible to it.

\section{Conclusions}

In this article I have, by focusing on transitions and processes of contestation and change within Islam in Britain, presented a picture that contrasts sharply with the characterisation of Islam as a coherent, undifferentiated cultural formation. With these processes of contestation and change taken into account, it becomes much harder to argue coherently-as Huntington and his more uncompromising followers such as Bawer and Phillips do - that there exists a fundamental cultural tension between Western and Islamic cultures, and next to impossible to see events such as the London bombings in 2005 as the product of a profound cultural divide. More specifically, I have sought to show how, in response to a complex combination of tension across generations, New Labour policy and the distinct social makeup of the UK, Muslim organisations and intellectuals have begun to reach back into and "reclaim" the Islamic past to address challenges of the present. This effort has not been widely discussed - in part, I have suggested, because of a lack of scholarly focus on Islamic knowledge, but also because fails to fit the preconception common to Huntington and his followers as well as policymakers in the UK that the successful acculturation of Islam in Britain requires simply the liberalization of the tradition to "bring it up to speed" with modernity.

It would nevertheless be misleading to suggest that there are no points of tension within the Islamic tradition in Britain or between the Islamic tradition and wider British society. Government policy toward Muslims has responded to some genuine challenges, including a difficulty translating Islamic traditions and movements into the UK and a resulting tension between Muslim generations. The extent to which these difficulties have encouraged extreme interpretations of Islam is debatable; often overlooked in debates are factors such as foreign policy and poverty (young Muslims in the UK are more than twice as likely to be unemployed than the national average [60]). Nevertheless, they cannot be entirely discounted. Moreover, efforts at renewal also have internal tensions. RMW's emphasis on scholarly authority and the classical tradition has allowed it to bypass established centres of religious transmission and challenge literalism, but presently there is not yet the institutional capacity to creatively reinterpret this tradition and authoritatively address social questions about political rights, social relations, personal morality and the appropriate relation 
between these. As I have noted, some new Islamic educational institutions have emerged in recent years with something like this aim, but these are at best initial steps in what could be a long process.

There have also been tensions and difficulties within UK government policy toward Muslims. In this article I have offered an account of Islam and public policy in Britain that differs in some respects from accounts stressing the "domestication" of Islam and the "securitization" of Muslim communities. Nevertheless, it has been clear that, across successive governments, policy has been fixated on security, to the point where almost all government support given to Muslims has been justified by making reference to the need to counter extremism. New Labour were certainly guilty of this but it is perhaps the decision by the coalition to cease funding RMW in part because it addressed broader concerns than terrorism that perhaps provides the most vivid illustration. There has not been space in this article to fully consider this issue, but it may be that reducing the emphasis on combating extremism might, paradoxically, allow Islam in Britain to develop on its own terms, eventually even becoming stable, confident and capable of opposing extremism more effectively.

\section{Acknowledgements}

The research on which this article is based was made possible by a studentship provided by the Economic and Social Research Council (pta-031-2005-00210). Although based on research carried out between 2008 and 2010, this article has also benefitted considerably from conversations with colleagues at the University of Bristol with whom I worked on the "Muslim Participation in Contemporary Governance" project between 2011 and 2012. I am grateful in particular to Therese O'Toole, Daniel Nilsson DeHanas, Tariq Modood and Nasar Meer. Of course, I bear sole responsibility for the argument and any errors.

\section{Conflict of Interest}

The author declares no conflict of interest.

\section{References and Notes}

1. Appiah, Kwame Anthony. The Ethics of Identity. Princeton, NJ: Princeton University Press, 2005.

2. Huntington, Samuel P. The Clash of Civilizations: And the Remaking of World Order. London: Simon \& Schuster, 1997.

3. Scruton, Roger. The West and the Rest: Globalisation and the Terrorist Threat. London: Continuum, 2002.

4. Huntington, Samuel P. “The clash of civilizations?” Foreign Affairs, Summer 1993, pp. 22-49.

5. Roy, Olivier. Globalised Islam: The Search for a New Ummah. London: Hurst \& Co., 2004.

6. Mandaville, Peter. Transnational Muslim Politics: Reimagining the Umma. London: Routledge, 2001.

7. Gray, John. Al-Qaeda and What It Means to Be Modern. London: Faber \& Faber, 2003.

8. Beck, Ulrich. Cosmopolitan Vision. Cambridge: Polity, 2006.

9. Gove, Michael. Celsius 7/7. London: Weidenfield and Nicolson, 2006. 
10. Bawer, Bruce. While Europe Slept: How Radical Islam Is Destroying the West from Within. New York: Doubleday, 2006.

11. Phillips, Melanie. Londonistan. New York: Encounter Books, 2007.

12. Saeed, Abdullah. "Muslims in the West and their attitudes to full participation in Western societies: some reflections." In Secularism, Religion and Multicultural Citizenship. Edited by Geoffrey Brahm Levey and Tariq Modood. Cambridge: Cambridge University Press, 2009, pp. 200-15.

13. Ansari, Humayun. The Infidel Within: Muslims in Britain Since 1800. London: Hurst \& Co., 2004.

14. Gilliat-Ray, Sophie. Muslims in Britain: An Introduction. Cambridge: Cambridge University Press, 2010.

15. Lewis, Philip. Young, British and Muslim. London: Continuum, 2007.

16. Office for National Statistics. Religion in England and Wales 2011. London: Office for National Statistics, 2012.

17. Abdullah al-Mamun al-, Suhrawardy. The Sayings of Muhammad. New York: Arno, 1980.

18. Lewis, Philip. Islamic Britain. London: I. B. Tauris, 2002.

19. Bhatt, Chetan. Liberation and Purity: Race, New Religious Movements and the Ethics of Postmodernity. London: Routledge, 1997.

20. Birt, Jonathan. "Locating the British Imam: The Deobandi Ulama between Contested Authority and Public Policy Post-9/11." In European Muslims and the Secular State. Edited by Jocelyne Cesari and Seán McLoughlin. Aldershot: Ashgate, 2005, pp. 183-96.

21. Gale, Richard, and Simon Naylor. "Religion, planning and the city: the spatial politics of ethnic minority expression in British cities and towns." Ethnicities 2, no. 3 (2002): 387-409.

22. Gilliat-Ray, Sophie. "Educating the 'ulama: centres of Islamic religious training in Britain." Islam and Christian-Muslim Relations 17, no. 1 (2006): 55-76.

23. Dyke, Anya Hart. Mosques Made in Britain. London: Quilliam Foundation, 2009.

24. Cantle, Ted. Community Cohesion: A Report of the Independent Review Team. London: Home Office, 2001.

25. Yuval-Davis, Nira, Floya Anthias, and Eleonore Kofman. "Secure borders and safe haven and the gendered politics of belonging: beyond social cohesion." Ethnic and Racial Studies 28, no. 3 (2005): 513-35.

26. Parekh, Bhikhu. A New Politics of Identity: Political Principles for an Interdependent World. New York: Palgrave Macmillan, 2008.

27. Saleemi, Hassan. "Islamic activism in the UK: then and now." Presented at City Circle, London, 29 June 2007.

28. Goodman, Paul. "MINAB's mosques may not be so moderate." Daily Telegraph, 30 November 2007. http://www.telegraph.co.uk/comment/3644400/MINABs-mosques-maynot-be-so-moderate.html.

29. O'Toole, Therese, Daniel Nilsson DeHanas, Tariq Modood, Nasar Meer and Stephen H. Jones. Taking Part: Muslim Participation in Contemporary Governance. Bristol: University of Bristol, 2013. 
30. Birt, Jonathan. "Lobbying and marching: British Muslims and the state." In Muslim Britain: Communities Under Pressure. Edited by Tahir Abbas. London: Zed Books, 2005, pp. 92-106.

31. McLoughlin, Seán. "The state, new Muslim leaderships and Islam as a resource for public engagement in Britain." In European Muslims and the Secular State. Edited by Jocelyne Cesari and Seán McLoughlin. Aldershot: Ashgate, 2005, pp. 55-70.

32. Department for Communities and Local Government. Preventing Violent Extremism: Winning Hearts and Minds. Wetherby: Communities and Local Government Publications, 2007.

33. Thomas, Paul. "Failed and Friendless: The UK's 'Preventing Violent Extremism' Programme." The British Journal of Politics \& International Relations 12, no. 3 (2010): 442-58.

34. Kelly, Ruth. “Time for a British Version of Islam...” New Statesman, 9 April 2007, p. 11.

35. Modood, Tariq. "Muslims, religious equality and secularism." In Secularism, Religion and Multicultural Citizenship. Edited by Geoffrey Brahm Levey and Tariq Modood. Cambridge: Cambridge University Press, 2009, pp. 164-85.

36. Caeiro, Alexandre. "Religious authorities or political actors? The Muslim leaders of the French representative body of Islam." In European Muslims and the Secular State. Edited by Jocelyne Cesari and Seán McLoughlin. Aldershot: Ashgate, 2005, pp. 71-84.

37. Kundnani, Arun. Spooked: How Not To Prevent Violent Extremism. London: Institute of Race Relations, 2009.

38. Hansard. "House of Commons daily debates." United Kingdom Parliament, 26 February 2009. Available online: http:/www.publications.parliament.uk/pa/cm200809/cmhansrd/cm090226/ text/90226w0033.htm (accessed on 12 March 2010).

39. Higher Education Funding Council for England. Islamic Studies: Trends and Profiles. London: HEFCE, 2008.

40. Siddiqui, Ataullah. Islam at Universities in England: Meeting the Needs and Investing in the Future. Leicester: The Markfield Institute, 2007.

41. Suleiman, Yasir. Contextualising Islam in Britain: Exploratory Perspectives. Cambridge: Centre of Islamic Studies, 2009.

42. Paton, Rob, Haider Ali, and Lee Taylor. "Government support for faith-based organizations: the case of a development programme for faith leaders." Public Money \& Management 29, no. 6 (2009): 363-70.

43. Yazbeck Haddad, Yvonne, and Michael J. Balz. "Taming the imams: European governments and Islamic preachers since 9/11." Islam and Christian-Muslim Relations 19, no. 2 (2008): 215-35.

44. Geaves, Ron. "Drawing on the past to transform the present: contemporary challenges for training and preparing British imams." Journal of Muslim Minority Affairs 28, no. 1 (2008): 99-112.

45. Geaves, Ron. "The symbolic construction of the walls of Deoband." Islam and Christian-Muslim Relations 23, no. 3 (2012): 315-28.

46. Darsh, Syed M. Questions and Answers about Islam. London: TaHa, 1997.

47. Kundnani, Arun. The End of Tolerance: Racism in 21st Century Britain. London: Pluto Press, 2007. 
48. McGhee, Derek. The End of Multiculturalism? Terrorism, Integration and Human Rights. Maidenhead: Open University Press, 2008.

49. Bevir, Mark. "Governance and governmentality after neoliberalism." Policy \& Politics 39, no. 4 (2011): 457-71.

50. Birt, Yahya. "Governing Muslims after 9/11." In Thinking Through Islamophobia: Global Perspectives. Edited by S. Sayyid and Abdoolkarim Vakil. New York: C Hurst \& Co., 2011, pp. 117-28.

51. Birt, Yahya. "Good imam, bad imam: civic religion and national integration in Britain post-9/11." Muslim World 96, no. 4 (2006): 687-705.

52. Brown, Katherine E. "The promise and perils of women's participation in UK mosques: the impact of securitization agendas on identity, gender and community." British Journal of Politics and International Relations 10, no. 3 (2008): 472-91.

53. Sunier, Thij1. "Domesticating Islam: exploring academic knowledge production on Islam and Muslims in European societies." Ethnic and Racial Studies, 2013, forthcoming.

54. Webb, Suhaib. "From protest to engagement." Presented at a Radical Middle Way event held at Westminster Central Hall, London, 24 February 2007.

55. Abd-Allah, Umar F. "Islamic extremism in the context of globalism." Presented at a Radical Middle Way event held at Birmingham Central Mosque, Birmingham, 18 November 2006.

56. Murad, Abdal-Hakim. Untitled talk presented at the launch of the Radical Middle Way, Kensington Town Hall, London, 6 December 2005.

57. Murad, Abdal-Hakim. "British and Muslim?" Masud, 17 September 1997. http://www.masud.co.uk/ISLAM/ahm/british.htm.

58. Murad, Abdal-Hakim. Muslim Songs of the British Isles: Arranged for Schools. London: Quilliam Press, 2005.

59. Hansard. "House of Commons daily debates." United Kingdom Parliament, 10 June 2009. http://www.publications.parliament.uk/pa/cm200809/cmhansrd/cm090610/halltext/90610h000 4.htm.

60. David, Blanchflower. “The lost Muslim generation.” New Statesman, 15 February 2010. 


\title{
Minority Political Representation: Muslim Councilors in Newham and Hackney
}

\author{
Eren Tatari and Ahmet Yükleyen
}

\begin{abstract}
Scholars have long been intrigued by the role of minority elected officials in representing the interests of their communities. There is an on-going debate on whether distinctive minority agendas exist and whether the existence of minority representatives (descriptive representation) is a necessary condition to secure the representation of minority interests (substantive representation). This article analyzes original interview data to examine these issues through a case study of Muslim city councilors and the dynamics of local government in the Newham and Hackney Borough Councils of London. It finds that the exceptionally high ethnic diversity of Newham with no dominant ethnic group, the lack of racial or religious divides among neighborhoods, and low racial tensions shapes the political culture of the Council, as well as the Muslim councilors, and yields high responsiveness for all minorities. It also finds that nonMuslim councilors play a significant role in the substantive representation of minority interests, including Muslim interests. In contrast, the case study of the Hackney Council reveals that beyond high party fragmentation, ethnicity and religiosity of the Muslim councilors vary widely and hinder effective representation. In addition, their political incorporation is low, and the leadership positions they hold seem to have symbolic rather than substantive impact. The political behavior and representative styles of Muslim councilors reveal a balancing perspective, whereby they advocate for group interests with a more moderate tone. These factors account for the low government responsiveness to Muslim interests in Hackney.
\end{abstract}

Reprinted from Religions. Cite as: Tatari, E.; Yükleyen, A. "Minority Political Representation: Muslim Councilors in Newham and Hackney." Religions 4 (2013): 502-528.

\section{Introduction}

Scholars have long been intrigued by the role of minority elected officials in representing the interests of their communities. There is an on-going debate on whether distinctive minority agendas exist and whether the existence of minority representatives (descriptive representation) is a necessary condition to secure the representation of minority interests (substantive representation). Descriptive representation refers to how much and in what ways the representatives resemble the represented; whereas substantive representation involves actions of the representatives on behalf of the represented, which is assessed through policy outcomes. This article analyzes original interview data based on fifty-one interviews conducted in London between June 2006 and August 2009 to 
examine these issues through a case study of Muslim city councilors and the dynamics of local government in the Newham Borough Council. It finds that the exceptionally high ethnic diversity of the borough with no dominant ethnic group, the lack of racial or religious divides among neighborhoods, and low racial tensions shapes the political culture of the Council, as well as the Muslim councilors, and yields high responsiveness for all minorities. It also finds that non-Muslim councilors play a significant role in the substantive representation of minority interests, including Muslim interests.

\section{The London Borough of Newham}

The London Borough of Newham was established in 1965 and is the most ethnically diverse local authority in England and Wales, with no particular ethnic group dominating [1]. Newham has the highest youth population and the second highest percentage of Muslims in Britain (24.3\%), after Tower Hamlets. Based on 2006 Office for National Statistics estimates, over 39\% of the population is White, 38\% is Asian (12.2\% Indian, 10\% Bengali, and 8.9\% Pakistani), $20 \%$ is black (6.5\% Caribbean and $12.4 \%$ African), and $1.6 \%$ is Chinese [2]. Newham is also known for its poverty. Although there has been some regeneration and investment, particularly new housing, in the borough over the last two decades, based on the 2006 Index of Multiple Deprivation scores, it is still the eleventh most deprived local authority in England and Wales and the third in London [2]. This high diversity coupled with high levels of deprivation leads to some racial tension. Councilor Abdulkarim Sheikh, one of the longest serving Muslim councilors in Newham, confirmed that there are incidents of hate crime in Newham, like being called Bin Laden because of a long beard or being insulted on the bus for wearing a headscarf. Yet, he also contended that the police and the Muslim community have good relations and argued that the relatively low levels of racial tension can be attributed to the make-up of the population, where no ethnic group dominates. Since whites and all other ethnic minority groups are less than $30 \%$ of the overall population of the borough, they are all minorities. Unlike most other London boroughs, Newham's neighborhoods are not segregated along religious or ethnic lines. Additionally, the council has implemented certain policies, which contributed to the social cohesion of the borough. For instance, Newham schools are closed for Eid, as well as other religious holidays, and the council flies the flag of every country on its national day.

The number of Islamic schools has increased from one to four in the last decade, and the borough has the second highest number of mosques (37) after Tower Hamlets. Twelve percent of grant money allocated to volunteer groups by the Newham Council is distributed among predominantly Muslim groups, despite the fact that $24.3 \%$ of the borough's population is Muslim. Although Muslim immigration started in the late nineteenth century, the numbers were miniscule until the post-World War II period. In the 1911 census, there were only 143 Asians recorded in East Ham and seventeen in West Ham [3], and by the 1921 census, there were 1,000 Indians in Canning Town alone [4]. As the British government and large companies began to recruit workers from Commonwealth countries, Newham began to develop a significant Muslim population in the 1960s and 1970s. Initially, the majority of immigration from India and Pakistan comprised of single workingmen, who subsequently brought over their wives and children in the 1970s and 
1980s. They worked as seamen; ship builders at the docks; construction workers in the sugar refineries, flourmills and leather factories; and at the Dagenham Ford factory.

Today, 53\% of the 60,000 Muslims living in Newham are foreign-born. Eighty percent of Newham's Muslim population is of South Asian origin: with 19,000 Pakistanis, 20,000 Bengalis, and 7,000 Gujarati Indians. The remaining minority includes 6,000 African Muslims (mostly Somalis, Nigerians, and Tanzanians), more than 1,000 white British Muslims, and 2,000 other white Muslims (mainly from Eastern Europe and Turkey). A majority of the mosques are Hanafi Sunnis of Barelvi and Deobandi schools. ${ }^{1}$ In addition, there are a few Wahhabi-influenced mosques, a Shia mosque, and an Ahmadi organization. There are two umbrella organizations active in the Muslim community. Newham Muslim Alliance represents the thirty affiliated mosques in Newham in consultation with the Council, whereas Newham Muslim Citizen's Association is an apolitical association appealing to secular Muslims. Overall, Newham and its Muslim community can be characterized by diversity, deprivation, and strong community involvement.

After the 2000 Race Relations Amendment Act, public authorities were required to fulfill steps to identify and address racial discrimination, promote racial equality, and publish yearly Racial Equality Schemes. Newham Council's 2002 Racial Equality Scheme sets out the aims of eliminating racial discrimination, promoting equality of opportunity, and encouraging good racial relations between people of different racial groups. It also requires ethnic monitoring and sponsors research to evaluate the impact of council policies on racial equality and diversity. Furthermore, Newham Community Strategy, published in 2003 by the Local Strategic Partnership, sets the priorities for spending the Neighbourhood Renewal Fund awarded by the central government into these categories: health and wellbeing, crime and antisocial behavior, environment and housing, employment, community, and social regeneration of young people. The second target is to build an active and inclusive community, such that "everyone in the borough should have the same chances in life, whatever their background and Newham should be a place where people live harmoniously and respect each other." It outlines three main strategies to achieve these goals: promoting equalities, the Supporting People me to help vulnerable people in care to live independently, and community involvement through the community forums and other consultative mechanisms and partnerships.

The Newham Community and Police Forum enables local residents to become involved in policing matters and has regular public meetings to discuss community safety and policing. Muslim councilors and associations regularly attend these meetings, and raise issues of antisocial behavior and racial and religious discrimination. The police also have an independent advisory group consisting of eighteen members, four of whom are Muslim. This group attends planning meetings relevant to policing at community events and overseas operations.

As mentioned earlier, community relations in Newham are relatively smooth compared to other cities with substantial Muslim populations (Bradford, Burnley, and Birmingham), which experienced race riots. Community workers attribute Newham's cohesion to its diversity and residential feel. In

\footnotetext{
1 These are the two major Sunni orthodox schools influential to sub-continental India and Muslim immigrants from this region. Deobandi promotes strict following of the Prophet's tradition. They also believe in the role of Saints. However, the Barelvi school is more puritanical and rejects Saints.
} 
the 1970s and 1980s, the British National Party (BNP) heavily targeted Newham, and racist murders were commonplace. In the face of organized racism, the black and South Asian communities in Newham also became politically organized, setting up the Newham Defence Committee and the Newham Youth Movement that led to the foundation of the Newham Monitoring Project in 1980. In 1980, the murder of a young Muslim male prompted the founding of Newham Muslim Citizens Association. Right-wing groups continued to be active in Newham during the 1990s, but their strength has waned considerably since 2000 . There have not been any race-related uprisings in the borough since 2001 when a young Muslim was killed in disturbances.

The Muslim councilors and community members interviewed stated that although overt racist discrimination is rare, subtle forms of discrimination are persistent. Surveys show that a tenth of working-age men and women in Newham, particularly Pakistanis and black Africans, have experienced discrimination in employment on the grounds of race or ethnicity [5]. Newham does not have excessive antisocial behavior problems compared to neighboring inner-city boroughs. However, as anywhere, some young males loiter on the streets. One recurrent issue pertaining to Muslims is on Eid and Pakistan Independence Day, when numerous young Muslim males drive through Green Street with loud music and waving Pakistani flags. Elders hold campaigns in the mosques before Eid to try and dissuade young people from doing this, arguing that this behavior does not present a good image of the Muslim community. However, as one Newham councilor explained, police reports suggest that youth violence is not directly related to ethnic or religious differences but to conflict between rival schools or families. There are also concerns about fighting amongst Muslim youth, and Mosque elders hold talks with young men to try to defuse tensions by appealing to the common brotherhood of Islam.

Newham was profoundly affected by the London bombings. There was widespread fear of reprisals against mosques and Muslims, which turned out to be largely unfounded. In the week following the July 7 bombings, one faith crime and one incident of racist graffiti occurred [5]. The Newham Council, police, and Muslim associations showed unity, holding a gathering at the East Ham Town Hall to observe two minutes of silence in memory of the victims, condemning the bombings, and to discuss community safety. Newham Monitoring Project also held a meeting at the Minhaj-ul-Quran Mosque in Forest Gate to discuss the threat of terrorism in Newham. Metropolitan Police Commissioner Sir Ian Blair, Newham Mayor Sir Robin Wales, and MP Lyn Brown spoke against the bombings calling for no one community to be singled out for the attacks. Furthermore, Newham police organized information-sharing meetings between the borough commander, senior police officers, councilors and concerned groups, and consulted with mosque leaders on what the police response to the bombings should be. Mosque leadership expressed desire for life to resume normally, and rejected the offer of posting police officers outside the mosques.

Muslim councilors in Newham contend that international events impact community relations as much as local events. For instance, there was widespread local opposition to the wars in Afghanistan and Iraq. In 2003, an antiwar march on Green Street attracted 10,000 protesters, including people from mosques, trade unions and political parties. Responding to this popular sentiment, the Respect Party made major inroads in local politics in Newham, which has traditionally been a Labour stronghold. In the 2005 general elections, East Ham showed the seventh largest swing from Labour in the country. Newham Respect heavily targeted Muslims and 
the majority of its supporters in the East End are Muslims [6]. This may have precipitated a greater appreciation of Muslims as a distinct political force in Newham amongst the other political parties. In addition, days before the 2005 general election, a small group of Pakistani males, assumed to be associated with fringe Islamic movements Al-Muhajiroun and Hizb ut-Tahrir, drove down Green Street carrying posters against all the local candidates calling them "Satan" and shouting through loudhailers "voting is haram" in Urdu.

\subsection{The Newham Council}

The London Borough of Newham consists of twenty wards, each electing three councilors. Until 2002, the leader of the council was elected among the majority party, whereas the ceremonial mayor was elected by the full Council. However, the mayor and cabinet system was approved by the residents in a referendum held in January 2002, making Newham one of the three London boroughs (and one of thirteen in England) that have a directly elected mayor. Under the new system, the Civic Ambassador fulfils the role previously undertaken by the ceremonial mayor. The first mayor of Newham, Sir Robin Wales, was elected in the May 2002 local elections. Out of the five candidates staged in the first round of elections by Labour, Conservative, Liberal Democrats, Respect, and Christian People's Alliance, three were Muslim. Labour's Sir Robin Wales (64\%) beat Respect's Abdurrahman Jafar (36\%) in the second round. Judge Graham Lane, one of the longest-standing Newham councilors, criticizes the new mayoral system as being "...totally undemocratic. All the power goes to the mayor. In reality it is the election of a king. He/she makes all the decisions" [7]. Likewise, Respect Councilor Abdulkarim Sheikh, who is of Pakistani origin, lived in the borough for fifteen years before becoming active in local politics in the mid-1980s, contends that "The new system of directly elected mayor has blocked everything. Council does not have much to put in" [8]. In addition, the Newham Council has been an overwhelmingly Labour Council since its inception (see Table 1). Moreover, Labour did not lose a significant number of seats in Newham following the Iraq War.

Respect Clr Abdulkarim Sheikh argued that Labour's continued success in the 2006 local elections was largely because opposition did not act wisely and the Muslim vote was divided among too many Muslim candidates. He blamed the Liberal Democrats with staging the same "dirty game" as before and "playing Muslim against Muslim." He was the only incumbent who got re-elected after defecting from Labour. Labour Clr Graham Lane also argued that Newham does not have a very healthy democracy since it is hard to win a seat for other parties. Moreover, he contends that the Conservatives won only twice in the last thirty years because blacks vote solid Labour, and the Conservative Party fought a semi-racist campaign in the past [9]. The Respect Party also had support in Newham. Three Respect councilors were elected in May 2006 (Abdulkarim Sheikh, Asif Karim, and Hanif Abdulmuhit), all from the Green Street West ward. Since then, Councilors Karim and Abdulmuhit became Independents.

The first Muslim councilor was elected to Newham Council in 1990. The number of Muslim councilors has been increasing steadily since then. In the 1990 local elections, four Labour candidates (Shama Ahmad, Abdulkarim Sheikh, Riaz Mirza, and Akbar Chaudhary) were elected to Newham Council. 
Table 1. Composition of Newham Council, 1965-2009.

\begin{tabular}{llcccc}
\hline & $\begin{array}{c}\text { Overall } \\
\text { Control }\end{array}$ & Conservative & Labour & $\begin{array}{c}\text { Liberal } \\
\text { Democrat }\end{array}$ & Others \\
\hline & & & & & 3 CPA \\
2009 & Labour & - & 54 & - & $\begin{array}{c}\text { Independent } \\
1 \text { Respect }\end{array}$ \\
& & & & & 3 CPA \\
2006 & Labour & - & 54 & - & 3 Respect \\
2002 & Labour & - & 59 & - & 1 CPA \\
1998 & Labour & - & 60 & - & - \\
1994 & Labour & - & 59 & 1 & - \\
1990 & Labour & 2 & 57 & 1 & - \\
1986 & Labour & - & 60 & - & - \\
1982 & Labour & - & 54 & 6 & 9 \\
1978 & Labour & - & 57 & - & 7 \\
1974 & Labour & - & 51 & - & 21 \\
1971 & Labour & - & 53 & - & 10 \\
1968 & Labour & 6 & 30 & 3 & - \\
1964 & Labour & - & 50 & - & - \\
\hline
\end{tabular}

\subsubsection{Fragmentation}

There are two types of fragmentation: party and gender. We measure party fragmentation as the number of parties among Muslim councilors in a given council divided by the number of Muslim councilors, where the greater the number, the greater the fragmentation. Among the thirteen, there are three female Muslim councilors, one of whom (Clr Shama Ahmad) has been a councilor since 1990. Newham Muslim councilors are ethnically more mixed. Among the ten Muslim councilors during the 2002-2006 term, three were Bengalis, four Pakistanis, one Indian, and two Kashmiris. Likewise, all thirteen Muslim councilors during the 2006-2010 term were also South Asians from Pakistan, India, Bangladesh, and Kashmir.

Until 2005, when the first Muslim councilor defected to the Respect Party, all Muslim councilors were from the majority Labour Party. Hence, the party fragmentation was zero for the 1998 and 2002 terms, and 0.2 for the 2006 term. In the 2006-2010 term, only 77\% of Muslim councilors were in the majority party (see Table 2). As of January 2010, Newham has thirteen Muslim councilors (see Table 3). Ten are from the Labour Party, one from Respect, and two were elected as Respect candidates in May 2006 and have since become Independents. Clr Sheikh, who unsuccessfully tried to run as an Independent, joined the Labour Party in the late 1980s and was elected as a councilor in May 1990. He has been a Labour councilor since 1990 and defected to Respect in 2005. He served as mayor, deputy leader, leader, and finally as leader of Respect Party. He explained his defection from the Labour Party:

There is a strong control apparatus within the Labour Party as the whip. We need to treat all sections of the society equally, we are not asking for special treatment, but equal status and equal opportunity so there is harmony. There is harmony in neighbourhoods, like between Hindus and Muslims (...) but as far as service delivery is concerned I am not very comfortable. Labour Party has to change within. I blame 
our [Muslim] brothers and sisters not to come up with a hard approach and say you will be losing more seats. Now they see, they were nearly losing 10 more seats [8].

Table 2. Descriptive Statistics of Muslim Councilors in Newham.

\begin{tabular}{|c|c|c|c|c|}
\hline Newham & 1998-2002 & 2002-2006 & 2006-2010 & Average \\
\hline Percent Muslim Population & NA & NA & NA & 24.31 \\
\hline $\begin{array}{l}\text { Number and Percent of Muslim } \\
\text { Councilors }\end{array}$ & $9(15.1 \%)$ & $10(16.7 \%)$ & $13(21.7 \%)$ & $10.67(17.8 \%)$ \\
\hline $\begin{array}{l}\text { Number of Parties among Muslim } \\
\text { Councilors and Party Fragmentation }\end{array}$ & $1(0)$ & $1(0)$ & $3(0.2)$ & $1.33(0.08)$ \\
\hline $\begin{array}{l}\text { Percent Muslim Councilors in Majority } \\
\text { Party }\end{array}$ & 100 & 100 & 76.9 & 92.3 \\
\hline Mean Seniority of Muslim Councilors & 4.6 & 6.5 & 6.2 & 5.7 \\
\hline $\begin{array}{l}\text { Number of Leadership Positions held by } \\
\text { Muslim Councilors }\end{array}$ & 6 & 3 & 6 & 5 \\
\hline $\begin{array}{l}\text { Number of Prestigious Committee } \\
\text { Assignments held by Muslim Councilors }\end{array}$ & 4 & 13 & 12 & 9.7 \\
\hline Percent Majority Party Seats & Labour $100 \%$ & Labour $98.3 \%$ & Labour $90 \%$ & Labour $96.1 \%$ \\
\hline Percent Ethnic Population in Borough & 60.6 & 58 & 55.6 & 58.1 \\
\hline
\end{tabular}

Table 3. Party Breakdown of Muslim Councilors in Newham, 1982-2010.

\begin{tabular}{cccccc}
\hline & Labour & Independent & Respect & Total & Female \\
\hline $\mathbf{1 9 9 0 - 1 9 9 4}$ & 4 & - & - & 4 & 1 \\
$\mathbf{1 9 9 4 - 1 9 9 8}$ & 7 & - & - & 7 & 2 \\
$\mathbf{1 9 9 8 - 2 0 0 2}$ & 9 & - & - & 9 & 2 \\
$\mathbf{2 0 0 2 - 2 0 0 6}$ & 9 & - & 1 & 10 & 2 \\
May 2006 & 10 & - & 3 & 13 & 3 \\
Jan 2009 & 10 & 2 & 1 & 13 & 3 \\
\hline
\end{tabular}

He argued that nobody was listening while the community was suffering and their genuine demands were not being met [8]. Although there were ten Labour Muslim councilors at the time of the interview, Clr Sheikh contends that they do not have much autonomy, and that their "lips are tied." He argued that within the Labour Party there is a strong whip system, which demands councilors not to speak for or against Party decisions. On the other hand, being a Respect councilor gives him a "free hand" and lets him speak up his mind [8]. He contends that although a good proportion of the Labour Party is Muslim, they were helpless and unable to change the Party over time because of the whip structure put up in place [8].

Gender fragmentation refers to the ways in which gender impacts the representative roles of councilors. The experience of Newham Clr Rohima Rahman illustrates gender fragmentation as well as the impact of gender fragmentation on substantive representation of Muslim interests. She is a first-generation immigrant from Bangladesh and was elected in 2006 at the age of 33. In her brief tenure in office, she has been an active advocate of Muslim women's interests, yet taking a balancing perspective. Together with Clr Shama Ahmad, she established an English literacy 
program for Muslim women, which is supported by the Newham Council. She explained the necessity for the program as follows:

They [Muslim women] say, I have been here for 20 years" but they have never been out of Newham or out of their locality of their house! They have never been to city parks... last week we took them by DLR to different places, they said I cannot believe this train goes without driver... majority are thirty plus, not that old. Think how their children are abusing that system, thinking mom doesn't know where I am going... [10].

Education of Muslim women is also important to remedy the vast gap with their children. It is common for second-generation Muslims not to speak the native tongue of their parents, and for parents, especially mothers, to speak very little English. This causes serious problems in that:

Sometimes we see Muslim children drifting away from mainstream system, their mothers or parents don't speak English. They don't know whether the child is going to school or is into bad habits. They might be wearing scarf at home but as soon as they go out, we see with our own eyes, they take it off. Parents don't know, they cannot communicate with their schools [10].

Clr Rahman experiences ethnic, religious, and gender stereotyping in her council work. She explained the discomfiture in her interaction with white constituents as follows:

Whites come, they show they feel comfortable but I don't know how they feel inside. They hear my name and expect a male councilor to be there. When they see a scarf, recently we had a consultation meeting on zoning, the way one or two approached me, the first expression I saw was they didn't expect me to be at that level, when I started speaking to them, explaining them the issues, explaining them the advantages and disadvantages, they really liked it, I felt their attitudes have changed [10].

In her political and public life, she, like all other Muslim councilors, has to find a level of compromise between her religious beliefs and doctrines, and the British way of life. She told that:

Sometimes I socialize with other colleagues, I talk with them and handshake, I chose that myself to be in this system, if there are certain issues if Islam does not allow me to do, I am married, my husband is okay with this, I know my limits, if I am in a Muslim community I don't hand shake that's not in our system, but if it is a white non-Muslim person I do it, it is their tradition I want to value that. But some white men know Muslim women don't hand shake so when they see my headscarf they don't extend their hands (...) but if they do, I shake it, that's not how we should show the world what Islam is, they are offering friendship and you refuse it, no [10].

As a female Muslim councilor, she faces varying levels of discrimination or different treatment from male Muslim councilors, Muslim constituents, and non-Muslims. When asked how Muslim male councilors responded to her, she replied:

At the beginning, I have seen some male Muslims' attitudes was "why you are here if you are wearing scarf, you should be at home." But I have changed that. I believe Islam is modern... all there is, now Qur'an has it, science is there. Women have a big role in Islam as well. To change community and women's needs, and my Muslim women's needs, set up a role model for other Muslim women to come to politics... [10]. 
Likewise, she criticized the way Muslim male constituents treat her during surgery or mosque visits:

I have been to a few mosques, and the way they see us, they don't treat a white or non-Muslim councilor that way. Sometimes we find that part quite difficult. For example, if there is a white female councilor and me, they will handshake with her and say "oh madam, madam." But they talk to you as if they know you from long ago, and you are his daughter, no respect. I don't like it, that's why I try to avoid those kinds of people. When they come to me for help, I try my best to show them I am capable, same as that other person actually. They sometimes feel and treat you low. They demand things more from us. It is not requesting it is demanding. I still try to help them [10].

Among the sixty Newham councilors, she is the only one who wears the headscarf. She said she is proud to represent it and would like to see more Muslim women in the council [10]. She has been offended when non-Muslim councilors offered her to join them in the pub to discuss council matters. She also points that non-Muslim councilors are confused because Muslim councilors practice Islam differently; for instance, some drink alcohol and others do not.

One of the challenges to her political career is that she feels excluded from the male-dominated public spaces among the Muslim community, as well as the white English community:

For example, in Muslim community when there is an important issue, to ask for vote, all men go to the mosque...That's our culture, it is the gathering place for men. Pub is the same in British culture, they relax, talk, make decisions, drink. This is their gathering place. But we do miss out, the more I talk and socialize with you, the more I will know about you. Otherwise, if we just say "hi" and "bye" we have a distance, and we don't understand each other we don't have that dialogue. And here in politics it is very important to know each other, without support you cannot do anything, especially being minority, we need to get everybody's support not just Muslim or minority councilors [10].

She said she goes to the women in the literacy program to ask for votes and believes that women are more important in voting time, for they can also convince men. The other two councilors from her ward are Pakistani males. I asked her if female constituents come to see her more. Clr Rahman replied that she has "noticed that more men come to women. More men come to me. Men feel more comfortable with women, when they have a problem they feel uncomfortable to talk to a man and say 'I am having this problem.' But with women they don't feel that" [10]. She strongly feels that minority representation is important to address the needs of minority communities. For example:

...because I am female and I am from Bengali community I speak several different languages. So ethnic minorities feel that if they don't speak English they can come to me and talk in their language, where they can address the issue and problem they are facing. So they feel I can help them [10].

In conclusion, Clr Rahman faces different forms of discrimination from her Muslim male colleagues and constituents, as well as white constituents and councilors.

\subsubsection{Political Incorporation}

Political incorporation of Muslim councilors in Newham (number of leadership positions they hold, their mean seniority/average number of years served as a councilor, and strategic institutional 
positioning) is notably high. Among the 36 Newham mayors (1965-2002), three were Muslims. The first Muslim mayor of Newham was Shama Ahmad (1996-1997) who was also the first and only Muslim female mayor of Newham. She was followed by Abdulkarim Sheikh (1998-1999), and Riaz Ahmad Mirza (1999-2000). Moreover, the average of the mean seniority of Muslim councilors for the three terms was 5.7 years. In the 1998-2002 term, Newham Muslim councilors had the fifth highest mean seniority; and the seventh highest in the 2002-2006 and 2006-2010 terms. In the 1998-2002 term, Newham Muslim councilors held the highest number of leadership positions. In the 2002-2006 term, they held the fifth highest, and in the 2006-2010 term, the third highest, number of leadership positions. In all three terms, Muslim councilors in Newham held the second highest number of prestigious committee assignments such as those that impact the greatest number of residents. In the current term, thirteen Muslim councilors hold six leadership positions and twelve prestigious committee assignments.

\subsubsection{Political Behavior and Representative Styles}

The political behavior and the representative styles of Muslim and non-Muslim councilors in Newham are rather similar. Arguably due to the political culture of the borough and the council, non-Muslim councilors are more understanding and responsive to Muslim interests and the interests of other minorities. Likewise, Muslim councilors take a more balancing perspective and they do not unequivocally support all Muslim demands at all costs but balance the interests of Muslims with the other minority groups and the borough. In the case of Newham, both Muslim and non-Muslim councilors are able to weigh the advantages and disadvantages of minority demands and council decisions for minority groups and the borough.

Among the issues of concern for the Newham Muslim community, two are particularly noteworthy for the purposes of this study; namely, the establishment of a Muslim cemetery, and opposition to mosque applications, in particular, the Abbey Mills Mosque in Stratford. The key committee for both the issues is the planning committee. Although the planning committee is independent in its decision-making, councilors do not have a lot of discretion and are advised by council officers as to what the legislation dictates. It is occasional that councilors can exercise some judgment [9]. Newham Muslims, who constituted one fifth of the population, have lobbied the council for a separate Muslim cemetery for decades, before being granted a separate section in the only council-run burial ground in 1991. West Ham Cemetery at Forest Gate, found in 1857, is the only cemetery owned and managed by the Newham Council. It is divided into three areas, consecrated, unconsecrated, and a section for Muslim burials. Clr Abdulkarim Sheikh, the longest-serving Muslim councilor in Newham, played a crucial role in establishing the Muslim section in the West Ham Cemetery, which is in use since 1991 [8]. As the only Respect councilor during the 2006-2010 term, his views and political behavior lean towards a group representative. He decided to be a councilor because he "thought that the service delivery was not tailored to the composition of the population. And if you have to say something, if you stand in front of the town hall and make noise, it does not make any difference. So it is better to be involved in the decision-making process" [8]. He acknowledged that although he counts on the votes of the 4,000 Muslims in his ward, he also needs the votes of other communities to get elected [8]. 
In the 2006 local elections, he fought his first campaign as a Respect candidate. He said that the campaign was not focused on Muslim issues as such but focused on specific local issues, such as Sir Robin Wales' proposal to replace an historic market with Walmart and closing down a secondary school. Clr Sheikh has been involved with the Newham Alliance of Islamic Associations since it was formed in 1981. Dr. Zulfiqar Ali became the chairperson of the same organization in 2007 after being elected as a councilor. Clr Sheikh claimed that partially due to his involvement in this organization, he is more aware of Muslim issues than the other Muslim and non-Muslim councilors [8]. He has tried to help out the Muslim community in the public sphere because he believes that "To be a good Muslim, you have to be a good citizen" [8]. He told me that he is the only Muslim councilor in Newham who refuses to come to evening meetings in the council during Ramadan.

Clr Sheikh named mosque applications as one of the "burning issues" in Newham. For instance, the planning application for Green Street Mosque was objected by the neighbors and, according to Clr Sheikh, council officers were inefficient in helping the Muslim community to prepare a successful application. Mosque applications are often rejected on the basis that (a) there are too many mosques, (b) it is encroaching on others' privacy, and (c) it causes traffic and parking problems. Clr Sheikh stated that:

When I was on the planning committee and there was an application for a Hindu temple or synagogue I never objected. I said this is civil liberty. If we have churches established centuries ago, why should we have restrictions on others? Technically they have reasons to refuse, which should be addressed, but indirectly there is discrimination. Because the officers' job is to advice the client how they can improve their planning so it meets the requirements of the law and could be successful. Both officers and councilors have implicit discrimination. If one says no, it goes out of the window [8].

The development committee, which processes planning applications, had fifteen members since its inception sixteen years ago. However, Labour reduced the number of members to ten by the pretext that there is not as much work to be done by councilors. Although the opposition demanded to have two seats, only one seat was allocated, which makes it hard to impact decisions without a seconder. Furthermore, Clr Sheikh strongly believes that there is discrimination against Muslims in housing, and he commented that 'There are 80,000 housing units owned by the Council. No Muslim housing association, my heart bleeds. We don't have that spirit; people go for individual gains (...) Specific needs like wudu facilities, has to be addressed.' [8]. Bengali households are more likely than the white British to be living in local authority housing [11]. Whilst less than 40\% of the borough's overall population is white, $60 \%$ of council tenants are white [11].

Clr Sheikh helped Muslim constituents to get a center for the youth. Although the council designated funds, and the center was established a few years ago, it was never handed back to the Muslim community. Another contentious issue is the lack of an exclusively Muslim cemetery. When Muslim councilors, including Clr Sheikh, and constituents tried to negotiate with the local authority, they were told that it is not the responsibility of the Council, and that there is no money or land. After much opposition and demonstration, Muslims:

...were given 120 spaces for cemetery. We wanted to have a virgin land, certain direction for burials.

The nicest cemetery is the City of London Cemetery, but we did not get a chance to get space there. They 
said come and use it but bury as we do. We cannot do that. This is the local authority's job to negotiate but they have failed to do that [8].

On the other hand, Newham Clr Rohima Rahman's cautious approach to demands from Muslims is more representative of Newham's Muslim councilors. She has been an active community worker for over fifteen years. During her first term in office, she helped an Islamic school get planning application. However, she is cautious about small-scale faith schools established by non-qualified administrators and teachers:

It is not only an issue about planning but about managing it. How you will run it, if we give you permission, that's fine but how will you run it. These young people will come to your school, who will be responsible? What the kids' future will be, we have to consider all of this (...) Small schools ran by small communities is quite difficult (...) [10].

She is equally cautious when it comes to mosque applications. As in localities with high percentage of Muslims, mosque planning applications are an ongoing controversy in Newham. Contrary to common perception, Muslim councilors do not necessarily support all mosque applications. For instance, Clr Rohima Rahman acknowledged that sometimes new mosques create more problems than they solve, and "By building the mosque if it creates problems for others, I personally don't support building it to create more problems" [10]. On the other hand, non-Muslim councilor Alec Kellaway seemed equivocal on the issue and said that mosque applications are:

...mostly a concern because Newham is very crowded, and parking is always a problem. If they want a mosque in a small shop, there is not parking available. There are sizable mosques developed. There are no problems. Sometimes residents complain, but then it is resident associations who deal with noise or night parties.' [12].

His attitude is representative of the non-Muslim councilors in that he approaches the issue from a practical stance, weighing the pros and cons while trying to empathize with the minority group.

Another recent mosque controversy clearly revealed the political attitudes and representative styles of Muslim and non-Muslim councilors in Newham. In 2007, Tablighi Jamaat, a movement founded in India in 1927 with 80 million followers worldwide, submitted plans to build Britain's largest place of worship, the Abbey Mills Mosque, next to the 2010 Olympic Park in Newham. More than 48,000 people have petitioned the government to abolish plans for the 100-million-pound mega-mosque with a capacity for 12,000 worshippers to be built [13]. A Newham councilor from the Christian People's Alliance, Alan Craig, is leading the campaign against the mosque, while Judge Graham Lane, a white Englishman and one of the longest serving councilors in the Newham Council, takes a rational, unbiased stance [14]. In analyzing the dynamics of the debate, he explained that although in theory the planning committee is independent of the Council, it is likely that the mayor will get involved in such a controversial decision:

I got a feeling he is ambivalent, and since many Muslims are involved he doesn't want to annoy the Muslim community. However you have to make a decision based on planning law properly. Muslims are divided, and most Muslims are opposed to it. It is organized by a fundamentalist group with dubious connections. I would say that I would object to Westminster Abbey moving to Newham on the grounds that it is too big... Having a mosque with tens of thousands of people is too big for a densely populated 
area. It is an inappropriate place to build it; it has to be on the countryside. It has to be taken on planning grounds not religious grounds. Some Muslim councilors think it is something they ought to support, but there are one to two who see the planning arguments. The opposition is from Christian People's Alliance; the least people opposing this should be them. But they oppose due to planning arguments.... Council cannot interfere with planning decisions. But now the mayor will make his view known privately to the chair of the planning committee, but in law they have to make the decision. I don't think it will be a decision that is left entirely to the hands of Newham; Borris Johnson, the current mayor of London, and national government may have a say as well [9].

Although Clr Lane believes that Newham's strength is its diversity for there is no ruling minority, he alluded to discrimination by the mayor in cabinet appointments:

There are plenty of Asian councilors but they don't hold key positions. That's the interesting thing and it is to some extent the fault of the mayor, he gives them titles but the real jobs go to white names. When we held elections for those positions, we got a slightly better balance... Ayesha Chowdury is very intelligent and capable but they haven't given her anything to do these last four years. She has been fed up. But she is a very rich business woman, who owns 40-50 properties [9].

He argued that some Muslim constituents purposefully avoid going to surgeries of Muslim councilors but acknowledge the positive effects of having minority councilors:

Minority councilors change the way we operate here for the good because there are certain things we would have done different if it had been all white councilors. Having Asians and other we have become more aware of what the people need, that's been the good side of it. We realize that there are certain traditions in different communities that we ought to respect. And we understand those communities more [9].

Moreover, Clr Lane accused Muslim councilors, as well as some white councilors, for getting caught up in a patronage role, and thinking that they can do favors for people:

Where we won't tolerate is any sort of local patronage or corruption. It wasn't just Asian councilors in some cases who were doing this. White councilors were doing it as well. There was a custom here, when somebody was housed, they used to come and bring you a bottle of whiskey or a present. Now it is illegal and any gift over 25 pounds has to be reported. But in those days, nobody noticed it... one or two councilors, whites as well, thought that this was alright. That sort of thing is frowned upon and you would possibly lose your council seat. It could be reported to the standards board because it is kind of bribery [9].

He defined patronage as doing something that you benefit from, such as a councilor accepting money or a free ticket for helping a constituent. He also cited manipulating the rules and bullying council officers, like insisting to move a constituent up on the list for housing [9]. What a councilor can do to help his or her constituent is to get the details of their case, and take it up with the officer, "If you disagree with how it has been handled, you can challenge that. What you cannot do is ask for a favor to be done for that constituent" [9]. Hence, Clr Lane identifies the positive and negative impacts of the presence of minority councilors in a rather unbiased manner. Likewise, according to Clr Peck, the problem with patronage politics is that "...many Muslim representatives on 
institutional bodies operate within a more familiar patron-client mode in relation to their own communities" [15]. Similar to Clr Peck, Michael equally blames party strategies for sustaining this mode of local politics:

... there was a great willingness to talk to community leaders, who were perceived to be influential, in order to recruit into the Labour Party. From that period onwards, MPs looked to groups to whom they could offer patronage, via a "community leader," who would present the MP with (usually) the deportation or housing queries of his constituents. "Vote-brokering" became commonplace across the black communities, and it is a common slur upon modern community leaders that such forms of instrumental politics are still practiced. But that it did occur for so long is testament to the effectiveness of patronage in achieving for black communities at least some solutions to the immediate problems, although damaging to political participation and education in the long term.... Political empowerment of black and Asian communities was simply not on the agenda. ([15], p. 19-20).

The representative style of Alec Kellaway, another white Labour councilor since 1981, is also particularly telling for he is an active pastor among the Christian community in Newham. As most councilors, he also represents an ethnically mixed ward. He contends that "Ethnic communities vote along party lines, and the ethnic vote goes to Labour. There are very practicing Sikhs, Christians and Muslims in the Council. And they do reflect this in their campaigning and work, Labour Party is okay with this" [12]. He does not feel that Muslim councilors overemphasize their religious or ethnic background. He feels that it is normal for Muslim constituents to prefer Muslim elected officials over non-Muslims. African Christians prefer coming to see him in surgery, because people "tend to come to people they have met at events. We had a choral concert at Christmas, being seen at events like that encourages people to come and see us" [12].

\section{The London Borough of Hackney}

The case study of the Hackney Council reveals that beyond high party fragmentation, ethnicity and religiosity of the Muslim councilors vary widely and hinder effective representation. In addition, their political incorporation is low, and the leadership positions they hold seem to have symbolic rather than substantive impact. The political behavior and representative styles of Muslim councilors reveal a balancing perspective, referring to how they advocate group interests with moderation. However, both Muslim and non-Muslim councilors are also reserved to extend particular group rights to avoid the escalation of similar demands from the other minority groups in the borough. Finally, the Hackney Council had been through a period of political turmoil and instability since the late 1990s, which impacted the ability and willingness of minority councilors and the council as a whole to represent constituent interests effectively. Arguably, all these factors account for the low government responsiveness to Muslim interests in Hackney.

The London Borough of Hackney was established in 1965, uniting the metropolitan boroughs of Hackney, Shoreditch, and Stoke Newington. Similar to Newham, Hackney has been a hub of low-skilled immigration since the late nineteenth century, becoming an ethnically diverse borough. The proportion of ethnic minorities remained stable at 40.6\% from 1998 to 2006, and dropped to $38.9 \%$ in the current term (see Table 4). 
Table 4. Hackney Data.

\begin{tabular}{ccccc}
\hline Hackney & $\mathbf{1 9 9 8 - 2 0 0 2}$ & 2002-2006 & 2006-2010 & Average \\
\hline Percent Muslim Population & & & & 13.76 \\
Number and Percent of & $5(8.8 \%)$ & $10(17.5 \%)$ & $9(15.8 \%)$ & $8(14 \%)$ \\
Muslim Councilors & & & & \\
Number of Parties and & $3(0.6)$ & $3(0.3)$ & $3(0.3)$ & $3(0.4)$ \\
Fragmentation & 40 & 80 & 77.8 & 65.9 \\
Percent in Majority Party & 6.4 & 4 & 6.7 & 5.7 \\
Mean Seniority & 2 & 4 & 4 & 3.3 \\
Number of Leadership & & & & \\
Positions & 0 & 9 & 7 & 5.3 \\
Number of Prestigious & & & & \\
Committee Assignments & 58.3 & 93 & 91.8 & 84.4 \\
Percent Majority Party Seats & LAB $50.9 \%$ & LAB $77.2 \%$ & LAB 77.2\% & LAB $68.4 \%$ \\
Electoral Competitiveness & 40.6 & 40.6 & 38.9 & 0 \\
Percent Ethnic Population & $0 / 1$ & $0 / 1$ & $0 / 1$ & 0.04 \\
Cemetery & $3 / 93$ & $4 / 94$ & $4 / 94$ & 8.7 \\
Islamic School & 7 & 9 & 10 & 9 \\
Mosque & 8 & 9 & 10 & 49.5 \\
Percent Grant & 57.3 & 45.1 & 46.1 &
\end{tabular}

According to mid-2005 estimates, 47.3\% of Hackney residents describe themselves as white British, 10.6\% black African, 9.2\% black Caribbean, 4.1\% Indian, 2.9\% Bengali, and 1.4\% Pakistani [2]. There is also a large Turkish population in Hackney, many of whom are Turkish Cypriot. According to the 2001 Census, $66 \%$ of the resident population was born in the UK, while $29 \%$ was born outside of the UK and Europe. The 2001 Census also shows that Christianity (44\%) is the largest religion in Hackney, followed by Islam (18\%) and Judaism (4\%) [2]. A significant concentration of Hasidic Jews exists in the northern wards, which are represented by Orthodox Jewish councilors. There are many commonalities among the issues of concern for Orthodox Jews and Muslims in Hackney, like kosher or halal food provision, dress code regulations in schools, gender-separate education, and emphasis on religious education.

Comparable to Newham, Hackney is one of the most deprived boroughs in London as well as England. All Hackney wards are among the 10\% most deprived in England, and 47\% of children in Hackney live in low-income households [1]. In 1998 and 2002, Hackney was the second most deprived borough in London and became the most deprived borough in 2006 [1]. Furthermore, Hackney has one of the highest crime rates among London boroughs, but cooperation between local police and the council led to $28 \%$ reduction in crime rates between 2003 and 2007. Table 4 summarizes the data on Hackney Council and the borough relevant to this study. Hackney has the fourth largest Muslim population (13.8\%) among the 32 London boroughs.

Moreover, Hackney was the thirty-fifth least competitive borough in 1998. Due to the increase in the number of Labour seats from twenty-nine to forty-five, Hackney became the thirteenth least competitive borough in 2002 and the sixteenth in 2006. The percent of council grant money allocated to organizations with predominantly Muslim clients increased steadily from $8 \%$ in the 
1998-2002 term, to $9 \%$ in the 2002-2006 term, and 10\% in the 2006-2010 term. Although it is less than the percentage of Muslims in the Borough (13.8\%), it gradually approaches parity.

\subsection{The Hackney Council}

Since its establishment in 1965, Hackney had been a Labour run authority, except a period of Conservative administration from 1968 to 1972 (see Table 4). The borough is divided into nineteen electoral wards, each returning three councilors in a first three past the post election system. Currently, the fifty-seven seats representing the nineteen wards of the borough are divided up between the Labour Party with forty-five, the Conservative Party with nine, Liberal Democrats two, and the Green Party with a seat (see Table 4). During the 1998-2002 term, Labour held the majority holding only $51 \%$ of the seats and increased its majority to $77 \%$ in the following two terms (see Table 4).

Following the Mark Trotter affair, a child abuse scandal involving a council social worker, a period of changing coalitions occurred in the late 1990s. Hackney Labour Party split between councilors who were following Clr. Nick Tallentire and following Clr. John McCafferty, who succeeded getting the backing of the national Labour Party. By the 1998 elections, all but two of the Hackney New Labour councilors defected to the Liberal Democrats or the Conservatives, and a coalition was launched between the Liberal Democrats, the Conservatives, and two Green Party councilors. Later, there was a coalition between Labour led by Jules Pipe and the Conservatives led by Eric Ollerenshaw. After the 2002 local elections, Labour returned as the majority party, and unpredictably, it was one of the few boroughs where Labour did not lose any seats in the 2006 local elections (see Table 5).

Largely due to the period of instability following the Mark Trotter affair, the Audit Commission for Local Authorities expressed serious concerns about the performance of Hackney Council in its 2000 report, for most council services were failing. This led to considerable negative press coverage for the borough and the council. However, only four years later MORI reported that residents were significantly more satisfied than they had been in 2002. In addition, the Audit Commission reported that the council achieved three stars in 2007. All these developments have impacted the ability and willingness of the councilors to represent minority interests effectively.

Hackney is one of the three London boroughs governed by a directly-elected mayor and run by a mayor and cabinet system. Labour's Jules Pipe was the first directly elected mayor of Hackney in 2002 and got reelected in 2006. Under the new system, the Speaker fulfils the civic and ceremonial duties previously undertaken by the ceremonial mayor. The mayor of Hackney selects approximately nine councilors to make up the Cabinet. Cabinet members are responsible for the governance of the borough's civil service and represent the mayor and council on strategic bodies. The regulatory functions of the council are carried out by back-bench councilors. The planning and licensing committees make independent decisions that oversee both the private and public sector and decide upon a wide range of petitions for permission to build, demolish or transform the built environment. Additionally, the borough consists of two parliamentary constituencies, Hackney North and Stoke Newington, represented by Labour's Diane Abbott, and Hackney South and Shoreditch, represented by Labour's Meg Hillier. MP Diane Abbott was the first black woman elected to the British Parliament in 1987 and is a renowned civil rights activist. 
Table 5. Composition of Hackney Council, 1964-2009.

\begin{tabular}{lccccc}
\hline & Overall control & Conservative & Labour & Liberal Democrat & Others \\
\hline 2009 & Labour & 9 & 45 & 2 & 1 \\
2006 & Labour & 9 & 44 & 3 & 1 \\
2002 & Labour & 9 & 45 & 3 & - \\
1998 & Labour & 12 & 29 & 17 & 2 \\
1994 & Labour & 6 & 44 & 10 & - \\
1990 & Labour & 4 & 48 & 8 & - \\
1986 & Labour & 2 & 53 & 5 & - \\
1982 & Labour & 3 & 50 & 7 & - \\
1978 & Labour & 1 & 59 & - & - \\
1974 & Labour & - & 60 & - & - \\
1971 & Labour & - & 60 & - & - \\
1968 & Conservative & 31 & 27 & 2 & - \\
1964 & Labour & - & 60 & - & \\
\hline
\end{tabular}

The first Muslim elected to the Hackney Council was the Labour candidate Shuja Shaikh in 1974. He has been the only Muslim in the council for three terms, until the election of Syed Bangle in 1986. The first Muslim female elected to the Hackney Council was Meral Hussein Ece in 1994. Clr. Ece, who is of Turkish and Bengali background, is one of the few mixed-race Muslim councilors in London.

The number of Muslim councilors remained miniscule until the 1998 local elections when five Muslims were elected (see Table 6). The number of Muslim councilors doubled to ten in the 2002 local elections and dropped to nine in the 2006 elections. It is the only council among the two case study boroughs to see a drop, though minute, in the number of Muslim councilors during the three terms.

Table 6. Party Breakdown of Muslim Councilors in Hackney, 1974-2010.

\begin{tabular}{cccccc}
\hline & Labour & Conservative & Liberal Democrat & Total & Female \\
\hline $\mathbf{1 9 7 4 - 1 9 7 8}$ & 1 & - & - & 1 & - \\
$\mathbf{1 9 7 8}-\mathbf{1 9 8 2}$ & 1 & - & - & 1 & - \\
$\mathbf{1 9 8 2}-\mathbf{1 9 8 6}$ & 1 & - & - & 1 & - \\
$\mathbf{1 9 8 6}-\mathbf{1 9 9 0}$ & 2 & - & - & 2 & - \\
$\mathbf{1 9 9 0 - 1 9 9 4}$ & 3 & - & - & 3 & - \\
$\mathbf{1 9 9 4 - 1 9 9 8}$ & 2 & - & 1 & 3 & 1 \\
$\mathbf{1 9 9 8 - 2 0 0 2}$ & 2 & 1 & 2 & 5 & 1 \\
$\mathbf{2 0 0 2 - 2 0 0 6}$ & 8 & 1 & 1 & 10 & 2 \\
\hline
\end{tabular}

\subsubsection{Fragmentation}

Muslim councilors in Hackney are exceptionally diverse with regards to party affiliation, ethnic background, gender, age, and religiosity. The interview data shows that each of these sources of fragmentation hinders the cooperation among the Muslim councilors, in turn deterring government responsiveness to Muslim interests. However, unlike Newham, the strongest sources of fragmentation among the Muslim councilors in Hackney are ethnicity and religiosity. Even though the gender and party fragmentation ratios are high, their impact on the political behavior of Muslim councilors as a group is not as strong. 
On average, 14\% of Hackney Council was composed of Muslim councilors between 1998 and 2010, yet they were divided among Labour, Conservatives, and Liberal Democrats during each term. Less than half (40\%) were in the ruling Labour Party in the 1998-2002 term. This figured increased to $80 \%$ in the following term and remained at $78 \%$ in the $2006-2010$ term. Clr. Shuja Shaikh, the longest serving Muslim councilor in Hackney, was a Labour councilor from 1974 to 1996 and a Conservative since then. Currently, there are seven Muslim Labour councilors, one Conservative, and one Liberal Democrat. Hence, two of the nine Muslim councilors are in opposition, and seven are in the ruling Labour Party. The party fragmentation index was 0.3 for the first two terms and 0.4 for the current term. However, this high party fragmentation index does not impact the cooperation between Muslim councilors based on party lines. For instance, Clr. Demirci confirmed "Muslim councilors vote together on Muslim issues across party lines." [16]. Moreover, when it comes to ethnic minority issues or Muslim interests, Demirci "would ask for the support of the ethnic minority councilors. For example, we got a group of Muslim councilors that if we are facing an issue they would vote with me... There is that ethnic vote, I will have their support. But in terms of asking for advice, it depends on the subject, I would go to anyone." [16].

Hackney councilors are divided among four ethnicities. Out of the nine Muslim councilors, four have Indian ethnicity, three are Alevi Kurds, one is a Sunni Turk, and one is of Pakistani background. Moreover, what makes the ethnic fragmentation particularly influential is the presence of three Alevi Kurds (Gülay İçöz, Feryal Demirci, and Deniz Oğuzkanlı), who self-identify as either non-practicing cultural Muslims or atheists. Some Sunni Muslims, like Clr. Siddiqui, do not consider Alevis to be Muslims on theological grounds, which increases in-group tensions.

The three Alevi Kurds, who are in their thirties and were born in Turkey, and are in their thirties, were elected in 2006. Clr. İçöz and Demirci are two of the three Muslim female councilors in Hackney. Clr. Oğuzkanlı is a lawyer, who previously worked in Citizens' Advice Bureau—tackling residents' problems with benefits, housing, and immigration. He is a committed human rights activist and a member of Amnesty International and Lawyers for Liberty. Clr. Oğuzkanlı has been an active member of the Kurdish community in Hackney and is a founding member and trustee of the Kurdish Education and Training Centre. His commitments are increasing the number of police officers on the streets, improving schools, and getting young people involved in the community by setting up youth centers. Likewise, Clr. Demirci was elected the Chair of Scrutiny Committee for Youth in 2009, primarily due to her work with Turkish and Kurdish youth. Although she has no religion, Demirci commented, "I do come from a Muslim family, so regardless of me not having a religion, I am approached by Muslims and have close links with the Turkish Mosques." [16].

Moreover, the ratio of female Muslim councilors in Hackney is 0.33. However, gender fragmentation remains weak compared to religiosity and ethnic divide. For instance, UK-born Clr. Nargis Khan is one of the female Muslim councilors and one of the younger and more secular ones. Although she has been engaged in minority issues, she does not particularly focus on Muslim interests and appeal to the broader concerns of the local community. She first got elected in 2002 from the Dalston Ward and has been the Cabinet Member for Community and Leisure since 2004, holding a portfolio which includes health, adult social care, the voluntary and community sector, leisure, libraries and culture. Her political priorities include improving opportunities for children and getting more people actively involved in the community. She is the vice-chair of the Local 
Government Association's Community Wellbeing Board. In 2002, Clr. Nargis Khan contributed to the Cantle Review of Community Cohesion, suggesting practical solutions for the role of political and community leadership. She has also advised the Home Office task force Preventing Extremism Together, with a focus on engaging women in politics and public life. In 2006, Clr. Nargis Khan was appointed to the Commission for Integration and Cohesion, contributing to the commissions 2007 report Our Shared Future on how local areas can play a role in forging cohesive and resilient communities. In a TV interview, she expressed that faith is a personal matter for her and she does not feel it is necessary to express it through dress. She expressed that although she might not look at it on the face, she holds traditional values, and that she does not want to be elected based on her religious background but based on merit [17].

There is a stark divide between these young generation of councilors who self-identify either as cultural Muslims or as having no religion at all, and the four older Muslim councilors (Clr. Shuja Shaikh, Saleem Siddiqui, Faizullah Khan, and Muttalip Ünlüer) who are in their sixties or older and whose political views and behavior is informed by theological convictions. For instance, Saleem Siddiqui, a seventy year old Labor councilor of Indian origin, has been a councilor in Hackney since 1990. Despite being highly outspoken on moral issues like abortion, teen pregnancy, and alcohol related crimes, he has held prominent leadership positions in the Council. Clr. Siddiqui stated that his forthright stance has not caused any problems with the Labour Party. For example, he was the only councilor in Hackney who served as the mayor twice (1995-1996 and 2001-2002). In addition, he was the Chief Whip in 1993-1994, the Deputy Leader in 1994-1995, and is the current Chair of Hackney Standing Advisory Committee for Religious Education (SACRE). His attitude towards the non-observant Muslim councilors is the strictest among the four religious Muslim councilors, in that he does not "mix with them" at all. Moreover, he explained his stance towards the Alevi Kurdish councilors as follows:

Hackney Council cannot respond adequately to our needs. Problems are more than resources we have. Muslims have not made their case as the Muslim community. It is not the fault of the council or racism... They are not withholding. Jews get it because they made their case and fought for it, $2.5 \%$ have seventeen Jewish councilors, for 15\%-19\% Muslim there are not more than four Muslims, for I don't consider the Alevis Muslim. There is competition for resources. I believe in equitable rather than equal distribution. If my needs are more, I should get a bigger piece of the cake. [18].

Similar to Clr. Siddiqui, Islamic ideology of serving humanity led Clr. Shuja Shaikh to be a councilor. He runs his political campaigns on the Conservative Party platform, including single-sex schools. Since the beginning of his political career, Clr. Shaikh sought to establish a Muslim identity, leading other non-Muslim Asians to accuse him of wanting to separate the Asian group. Moreover, secular Muslims from all backgrounds are not supportive of the Muslim label as well. When asked whether the level of religiosity of the Muslim councilor would make a difference, he replied, "I think if the councilor is a secular Muslim, it would make a difference... a practicing Muslim councilor would carry more weight than a secular Muslim... It depends if the secular Muslim councilor is anti-Muslim or against observance. But if the secular Muslim works to help Muslims, he would carry as much weight as anybody else." [19]. Although he works with the other Muslim councilors, he also acknowledges the effects of party fragmentation in that: 
Outside you put on a united front, you cannot disagree with your party in the council or outside. Otherwise you will be gotten rid of or politically punished. But within the party you can talk, discuss, disagree or persuade other people to accept your point of view. But once within the council chamber you have to stick together. Muttalip [Clr. Ünlüer] is doing a good job within the party and trying to accept the point of view, as I do the same in my part. But I am in a better position because I am in opposition. That is why I can get up and say whatever I want to say. But they are in power, the party decides the policies and they have to stick together. My job is to attack them [19].

Unlike Clr. Siddiqui, Clr. Muttalip Ünlüer cooperates with Muslim councilors from all backgrounds, even "with atheist Kurdish councilors for our community's needs." [20]. For instance, after July 7 bombings, Muslim councilors initiated a bridging effort and brought together leaders of different faiths, the mayor and the police:

Muslims or others, it does not make a difference. People come to us with their problems, with housing, services...etc. seeking their rights. The only difference is if a Muslim constituent comes we say salamun alaykum... But we serve their rightful cases and behave them all the same... Muslims do not come with special demands. They are not aware that they can in fact. The Jewish people openly make special demands, but Muslims are not aware they can make those demands. [20].

\subsubsection{Political Incorporation}

The political incorporation of Muslim councilors in Hackney is relatively better than most other councils and does not seem to play a significant role in the low government responsiveness. Muslim councilors are relatively experienced with the lowest average seniority being four years, and they hold a notable number of leadership positions and committee assignments. In the 1998-2002 term, among the five Muslim councilors, the mean seniority was 6.4 years, making Hackney the third highest London borough with regards to the mean seniority of Muslim councilors. In the 2002-2006 term, five new Muslim councilors were elected; hence, the mean seniority of the ten Muslim councilors dropped to four years, the fourteenth highest among the 32 boroughs. However, in the 2006-2010 term, the mean seniority increased to 6.7 years (the sixth highest).

In the 1998-2002 term, five Muslim councilors held two leadership positions (the third highest); in the 2002-2006 term, ten Muslim councilors held only four positions (the second highest); and in the 2006-2010 term, nine Muslim councilors held four leadership positions (the fifth highest). Although Hackney has had fewer Muslim councilors compared to Newham, it has had a considerably higher number of Muslim mayors. Former Muslim mayors of Hackney include Clr. Syed Bangle (1987-1988), Clr. Sham (90-91), Clr. Saleem Siddiqui (1995-1996, 2001-2002), Clr. Mulla (2003-2004), Clr. Faizulla Khan (2007-2008). Notably, Clr. Siddiqui is the only councilor in the history of Hackney to serve as mayor twice. Moreover, in the 1998-2002 term, none of the five Muslim councilors held a prestigious committee assignment. However, in the 2002-2006 term, ten councilors held nine assignments (the third highest); and in the 2006-2010 term, nine held seven prestigious committee assignments (the seventh highest). 


\subsubsection{Political Behavior and Representative Styles}

The political behavior and representative styles of the younger and older generation of Muslim councilors vary. Although, ethnic and religious fragmentation puts them asunder and hinders their cooperation on Muslim issues, both groups advocate on behalf of Muslim interests with a balancing perspective. They advocate for group interests with a more moderate tone compared to Muslim councilors, such as in Tower Hamlets. However, both Muslim and non-Muslim councilors are also reserved to extend particular group rights to avoid the escalation of similar demands from the other minority groups in the borough. This seemingly paradoxical stance, advocating for Muslim interests yet refraining from extending specific group rights due to budgetary pressures, contributes to the low government responsiveness to Muslim interests in Hackney.

In the case of the non-practicing Muslim councilors, ethnic and religious ties overlap. For instance, in explaining her advocacy work, Clr. Feryal Demirci uses the terms ethnic interests and Muslim interests interchangeably. She explains the reasons for running in local elections as follows:

I have always been active in my community since a young age because of the issues of Kurds in Turkey. So being involved in the community center here, I built close relationship with the local party here, and began being interested in local politics and thought I could do this not just for my community but for all. I was a member of Labour Party for two or so years before I was approached by the Party to run for council. The idea came from them, and they felt that although they work with the community center, it would serve the community better if there was someone from the community who actually understood the issues. [16].

She also emphasized the fact that "People assume that you have a huge ethnic voter base, but not necessarily. A lot of our community is not even registered!" [16]. Despite self-identifying as not having a religion, she still advocates for Muslim interests, "There was an issue with getting permission for a school for Muslim kids from constituencies represented by Tory councilors. Muslim Labour councilors supported it as well. As an ethnic minority and as a woman I understand the issues with those communities better than my other colleagues, so when there is an issue, I am the first one to be asked for advice and I do advocate for those communities" [16].

Similarly, Clr. Siddiqui liaises with the police on issues of concern for the Muslim community. Moreover, "There was an issue when a police officer harassed a minority and arrested him, I took it up with the police chief and made the officer apologize. The point is to make officers realize they cannot break the line" [18]. Although he is very passionate about Muslim issues, he does not support all Muslim demands blindly. For instance, for a rejected mosque application he commented "Discrimination is there, I am not saying there is none, but the officers know the lines. The planning application came after it was established, and it was residential, not appropriate for a mosque, so they didn't get the permission" [18]. He cited another example when the Muslim community did not follow the appropriate procedures. Tawhid Boys School, an Islamic school established in 2000, applied to convert another building as an addition, "Yet they didn't even have permission for the first building. Officer didn't take it further since there was no complaint" [18].

The observant and non-observant Muslim councilors agree that minority representation is crucial for the substantive representation of minority interests. For instance, Clr. Demirci believes that minority representation "definitely matters" because: 
Although there are consultations, they sometimes overlook ethnic minorities when making policies because they do not understand. So it is very effective to have councilors from ethnic minorities because we raise the issues and policies are made to ensure that communities are considered. But also, sometimes there are certain allocated budgets and they cannot cater to the needs of every community but have to be universal. [16].

Likewise, Clr. Ünlüer contends that having Muslim councilors has positive effects for the community:

A non-Muslim cannot know a Muslim's needs more than a Muslim. We brought it up for instance to have a worship place in the council for Muslim employees. A Christian cannot think of this need ever, because he does not need it. For women, how to behave to them, not to shake hands, when I did not shake at the beginning they thought it was weird now they learned it. [20].

Likewise, Clr. Ünlüer told that "Me being a Muslim councilor must have been an inspiration for others" and "I wish to motivate young Muslims and find someone to take over my job when I leave." [20]. Although he encourages young people saying it would be helpful for the development of the community, few of them get involved [20]. Clr. Chris Kennedy, a forty-year-old white Labour councilor elected in 2002 to Hackney Council, also shares these opinions. He favors the idea of positive discrimination and having ethnic minority-only short-lists for parliament, which is an ongoing debate in Labour National Committee [20]. Clr. Kennedy believes that "Unless you deliberately start the process, it will not happen automatically because rules and general processes, even in Labour Party, favor white older males" [21]. He said that Hackney Mayor Jules Pipe "was told by the Labour Party that the cabinet should not be too white" [21]. He also contends "Cultural difference around the table helps to make a balanced decision. We try to vary gender and culture of the Speaker. When there is a Turkish constituent, the Turkish councilor can tell us better where they are tweaking the truth..." [21]. Likewise, Clr. Shuja Shaikh outlined the positive impacts of the presence of Muslim councilors as follows:

The very presence of a Muslim either as a councilor or any other representative makes a difference in the sense that the non-Muslims become conscious of the Muslim representative's presence and also of the Muslim community. It has two effects: one is that the non-Muslims come to know about the requirements, needs, and demands of Muslims. Also, it deters them from being racist or anti-Muslim... They would not express their prejudice openly, so it deters them. And the other element is gradual contact with the Muslim representative helps them to maintain continuous contact with the Muslim community and know more and more about it. It is a venue, an opportunity to learn more about Muslims [19].

Yet he also acknowledges that the representation styles of Muslim councilors would make a difference and lead to positive or negative consequences:

But it depends on the Muslim representative. If the Muslim elected representative is positive, then he or she will receive positive response from councilors and others. But if the person is negative and aggressive, then people do not like aggression. Also the representative needs to know how the system works, know the rules, regulations, laws, the way of behavior, and language, because words are important. If you use the wrong word in the wrong place, then people can misunderstand or do not know what you are saying. I think it is also important to speak loudly and distinctly...there is a learning 
process on both sides. We, the ethnic minorities, have to learn of and about the majority community... also we have a job to teach others about our culture and history. It is how you behave, kind, polite, but firm. In other words, you do not take insults [19].

Muslim constituents raise issues in his surgeries on personal and local level issues including housing, social security benefits, immigration problems, planning application for mosques, Islamic schools, hate crimes (especially women with headscarves), health, education...etc. No more burials take place in Hackney cemeteries, and the Muslim community bought a land in Edmonton Cemetery in Enfield. Slaughterhouses have to be licensed and inspected by the Department of Health and Safety. In Hackney, there is one privately owned business which allows Muslims to use its facilities to slaughter their animals. Secular social and cultural activities are funded by the council, but not religious activities. He believes that lack of English proficiency and communication skills of Muslims is the greatest barrier to accomplishing their requests.

The majority of Muslims who participate in public life are older, first-generation immigrants who lack a good command of English and do not understand the psychological and cultural connotations of words [19]. He points out the fact that the generation of 35-50-year-olds is lost from political life. They were born abroad but raised in the UK by first-generation immigrant parents planning to return to their country of origin; hence, they did not pay much attention to their children's development or integration. Whereas the new generation born and raised in the UK is already settled, and according to Clr. Shaikh, socio-politically they will do much better than the first-generation immigrants [19].

Another first-generation immigrant Muslim councilor, Muttalip Ünlüer, became a Labour Party member in 2000 upon the advice of another Muslim councilor and by "taking another Muslim councilor as a role model." He is one of the four councilors born in Turkey, but is the only Sunni and ethnic Turk. When he first joined the Party, Hackney Council, and especially the Labour Party, was in disarray with services coming close to a stop. He believes that since that time, there have been vast improvements in the borough and the council-where all services are restored, and it became a functioning council again. Clr. Ünlüer contends that although the Labour Party lost votes in many local authorities in the 2006 elections, this was not the case in Hackney, largely due to the hard work of local Labour councilors. He sought to be a councilor, because minorities do not know their rights and the services that are available to them. He pointed that councilors do not get high salaries or have prestige or power, and "the only reward is to help someone in need." [20]. Similar to the experiences of Muslim councilors of different ethnic backgrounds, Turkish constituents, even from other wards, prefer attending his surgery particularly because he speaks Turkish.

He has been an active leader in the Turkish community, centered on the Aziziye Mosque in Stoke Newington, run and attended by the Turkish community. Aziziye Mosque's planning application had been accepted 12 years ago, when there were only two Muslim councilors in the Hackney Council. However, community leaders chose not to approach the Muslim councilors, and it took the Council almost three years to grant the permission. Clr. Ünlüer had become a councilor by the time Aziziye Mosque applied to open a supplementary school. He emphasized the fact that the application went through the normal legal procedure, and no special provisions were made. The school, which is situated in the Mosque, receives funds from the Local Education Fund, but 
not the council. It has English classes for women, most of whom are Turkish, and after-school program for kids.

Muslim and non-Muslim councilors point to several barriers to the achievement of Muslim demands. Some barriers have to do with the Muslim community (lack of English proficiency, unfamiliarity with the system, laziness, and an unwillingness to integrate), while others are due to direct and indirect forms of discrimination and budgetary pressures. For instance, Clr. Kennedy acknowledged that there are forms of subtle discrimination against ethnic minority councilors. For example, what he calls "accentism" refers to prejudice caused by poor English skills of a councilor or constituent. It is hard to avoid it, for Kennedy even catches himself stereotyping because of accentism [21]. Clr. Siddiqui also addressed the problem and said that when there is discrimination "it is most subtle than apparent" [18]. For instance, he told the story of a former Muslim councilor in Hackney, who lost his seat because of a smear campaign. Apparently, there were 17 council workers with his last name, and an Orthodox Jew, who wanted his ward, gave an interview to a racist newspaper-accusing the Muslim councilor of nepotism and corruption [18]. Clr. Ünlüer also acknowledged that there are written and unwritten stereotypes of white English people as well as ethnic minorities [20]. According to Clr. Demirci, another systematic factor that hinders the substantive representation of Muslim interests, is the budget:

Hackney is a very multicultural borough. If you provide something catered for one community, you have to do it for others and that puts a huge pressure on the budget. So they will try to be sensitive but they will not cater to one community and that's where we come in. If it's a huge issue for my community but not so much for another community, then we need to put pressure and say "no, actually you need to design this service for our community and take these specificities into consideration" [16].

In regards to the Muslim community's failure to achieve a substantial amount of council grants, Clr. Siddiqui said "There is a system in place to get all these things, and there are things they lack: the knowledge of how the system works, and they have to establish that they have been a service provider" [18]. In all three cases - mosque, school and grant applications - he criticized the Muslim community, for "Muslims have not learnt there is a way to go about it. It's our fault, they keep it as personal not professional organizations" and "Hackney is in unfortunate situation. Muslim community is not well organized, and they are individualistic." [18]. According to Clr. Siddiqui, the best-working cohort of councilors is the Orthodox Jews, and the Muslim community does not:

... realize we have to work in the system. Orthodox Jews, I am praising them, there are seven recognized nurseries in this borough although only $2 \%$ Jews, two single-sex boy and two girl ones, they had three million of their own and the government gave them 10 million to run the system. They got this because they work with the system and they got the right. I am not saying they got it badly. It is not that they got 10 million so Muslims and Christians should get 10 million too. The Jews have two buildings for their old people, council gives them lunch, transportation, etc. for socialization. Muslims are $13.5 \%$ officially they have only three schools, but run on a family basis. They have been offered government grant, but they don't want it because they want to keep their hold on it. We live in the UK, so I don't drive on the right like I am in the US! If I do the other way, I will be in collision. Therefore, we have to follow these and live like this. We live here, we have to compromise a bit. [18]. 
Another impediment working against the Muslim community is prevalent lack of English proficiency and the unwillingness to get over this. For instance:

Certain people think their language isn't good enough to see their councilor so they contact me. I try to encourage them because it is not good for me to solve their case for them. They should come and have contact with you. His contact with his local representative gives two things to that person: the councilor needs to realize he needs their vote; second, our people should realize that they live in the UK, there is a system to work, and they will never learn it if I help them. I joke with my Turkish friends to turn off their Turkish TV. They must learn the language, go to the library, read children's books, and listen to radio. [18].

Clr. Ünlüer contend that, except the last three years (2003-2006), England had been rated the best among all European countries for foreigners not being discriminated against, and allowing their socioeconomical success. The one exception, he argued, is the Turks who are lazy themselves [20]. As for the barriers to the accomplishment of minority demands, he said that:

The problem is with the attitude of Muslim communities. All those I know, they see themselves as guests here. They don't want to get involved in the politics here, but earn enough and leave. But they cannot leave either, their children are born and raised here. So this is a mistake in our thinking, and the first reason why particularly Turks are not involved in local politics. I do not think it has anything to do with the system here. I do believe there is unwritten discrimination but I find ourselves more responsible for this lack. [20].

Finally, Muslim Public Affairs Committee (MPACUK) CEO Zulfi Bukhari and Newham Councilor Abdulkarim Sheikh pointed about another barrier to the accomplishment of Muslim demands, and blamed mosque structure for lack of civic engagement [8]. Clr. Sheikh has been involved in Muslim organizations for 32 years, and believes that some people are very orthodox and primitive in their approach; in particular, the public engagement of women is curtailed [8].

\section{Conclusions}

The data sheds light on the link between descriptive and substantive representation. Although the findings do not undermine the role of minority representatives in advocating minority interests, it reveals other causal factors. The data finds that the high ethnic diversity of the Newham Borough with no dominant ethnic group, the lack of racial or religious divides among neighborhoods, and low racial tensions shapes the political culture of the council as well as the Muslim councilors and yields effective minority representation. Newham's unique demographic characteristics and local sociopolitical culture render non-Muslim councilors a significant role in the substantive representation of minority interests, including Muslim interests.

On the other hand, the case study of Hackney Council reveals that beyond high party fragmentation, ethnicity and religiosity of the Muslim councilors vary widely, thus hindering effective representation. In addition, their political incorporation is low, and the leadership positions they hold seem to have symbolic rather than substantive impact. The political behavior and representative styles of Muslim councilors reveal a moderate level of advocacy for Muslim group interests. However, both Muslim and non-Muslim councilors are also reserved to extend particular group rights to avoid the escalation of similar demands from the other minority groups in 
the borough. Finally, the Hackney Council had been through a period of political turmoil and instability since the late 1990s, which impacted the ability and willingness of minority councilors and the Council as a whole to represent constituent interests effectively. All these factors account for the low government responsiveness to Muslim interests in Hackney.

The implication of Newham's case for broader discussions on representation is as follows: descriptive representation can serve substantive representation in local politics if the ethnic and religious composition of the local population is diverse enough without the dominance of a group. The voting power of a diverse local population encourages all politicians to collaborate with political representatives of the minority. The Hackney case supports this, as well as providing an example of how fragmentation on political, ethnic, religious, and gender lines prevents descriptive representation from transforming into substantive representation. In this case, the representatives from the minority groups remain mostly symbolic rather than serving group interests.

\section{Acknowledgements}

We thank Rollins College and the University of Mississippi for their continuous support for the research and writing of this article. Ahmet Yükleyen contributed to this article while he was on sabbatical at Sabanc1 University, Istanbul, Turkey with the support of TUBITAK's (The Scientific and Technological Research Council of Turkey) 2221 Fellowships for Visiting Scientists and Scientists on Sabbatical Leave Program.

\section{Conflicts of Interest}

The authors declare no conflict of interest.

\section{References and Notes}

1. Gareth Piggott. "Simpson's Diversity Indices by Ward, 1991 and 2001." Data Management and Analysis Group, Greater London Authority, London, 2006.

2. Office for National Statistics. "Neighbourhood Statistics 2006 Estimates." Available online: http://www.neighbourhood.statistics.gov.uk/dissemination/ (accessed on 22 December 2011).

3. John Widdowson and H. Block. "People Who Moved to Newham in London." Borough of Newham: Newham Libraries Service Educational Package Archives and Local Studies, Stratford Library, no date.

4. Geoffrey Bell. The Other Eastenders: Kamal Chunchie and West Ham's Early Black Community. London: Eastside Community Heritage, 2002.

5. Mark Taylor. "Newham Household Panel Survey: Education, Training and Employment Experiences in Newham.” Report of ISER (Institute for Social and Economic Research) University of Essex, 2005.

6. Newham Recorder. "Does George Galloway's Respect Party still have role to play in East London?" Available online: http://www.newhamrecorder.co.uk/ (accessed on 24 October 2013).

7. Kaveri Harriss. "Muslims in the London Borough of Newham." Background Paper for COMPAS, University of Oxford, 2006.

8. Abdulkarim Sheikh, 12 June 2006, interview. Newham Council, London. 
9. Graham Lane, 14 July 2009, interview. Newham Council, London.

10. Rohima Rahman, 14 July 2009, interview. Newham Council, London.

11. Nick Buck, Jonathan Burton, Annette Jäckle, Michael Merrett, and Emanuela Sala. Newham Household Panel Survey: The Demographic and Social Situation of Newham. A report prepared by Institute for Social and Economic Research, University of Essex, for the London Borough of Newham. London Borough of Newham, 2003.

12. Alec Kellaway, 14 July 2009, interview. Newham Council, London.

13. Joanna Sugden. "Setback for Muslim sect's 'mega-mosque' in London." The Times, 29 May 2007. http://www.thetimes.co.uk/tto/faith/article2098374.ece

14. Nooradeen Al-Baghdadi. "Concillor Attacks New Mosque." Ummah Pulse, 2007. http://ummahpulse.com/index.php?option=com_content\&task=view\&id=127\&Itemid=65.

15. Lucy Michael. "Leadership in Transition? Issues of Representation and Youth in British Muslim Communities.” Working Paper 12, ESRC/ODPM Postgraduate Research Programme, 2004, p. 20.

16. Feryal Demirci, 6 July 2009, interview. Hackney Council, London.

17. Clr. Nargis Khan's desire to become Britain's first Muslim woman MP led to her nomination for selection as Labour candidate for Bolton South-East. Although she was short listed for this safe Labour seat, Ms. Yasmin Qureishi was selected as Labour candidate for Bolton South-East. Available online: http://www.msnbc.msn.com/id/13689225/displaymode/1107/s/2/framenumber/ 3/ (accessed on 22 October 2013).

18. Saleem Siddiqui, 7 July 2009, interview. Hackney Council, London.

19. Shuja Shaikh, June 2006, interview. Hackney, London.

20. Muttalip Unluer, June 2006, interview. Aziziye Mosque, Stoke Newington, London.

21. Christopher Kennedy, 20 July 2009, interview. Hackney Council, London. 


\title{
Sport, Islam, and Muslims in Europe: In between or on the Margin?
}

\author{
Mahfoud Amara
}

\begin{abstract}
The aim of this paper is to reveal how misconceptions - or using the concept of Mohammed Arkoun, "the crisis of meanings"-about the role and position of Islam in Europe is influencing the discourse on sport, Islam, and immigration. France is selected as a case study for this paper as it is in this country where the debate on religion in general and Islam in particular seems to be more contentious in relation to the question of the integration of Muslim communities with secular (French republican) values. Recent sources of tensions include the ban of the burqa in the public space; the debate on national identity instigated by the former French president Nicholas Sarkozy, which became centered around the question of Islam and Muslims in France; the provocative cartoons about Prophet Mohammad in the satirical magazine Charlie Hebdo; opposition against the provision of halal meal in France's fast-food chain Quick; and resistance toward Qatar's plan to invest in deprived suburbs of France, to name just a few. The other context which this paper examines in relation to the question of sport, Islam, and the identity-making of Muslims in Europe is the phenomenon of "reverse migration" or the re-connection of athletes of Muslim background in Europe, or so-called Muslim neo-Europeans, with their (parents') country of origin. The paper argues that sport is another highly politicised space to judge the level of "integration" of Muslim athletes in European societies, and the degree of "religiosity" in their (parents') country of origin.
\end{abstract}

Reprinted from Religions. Cite as: Amara, M. "Sport, Islam, and Muslims in Europe: In between or on the Margin?" Religions 4 (2013): 644-656.

\section{Introduction}

The question of religion in Europe, particularly Islam, has been defined to a certain extent around the following dichotomies: homogeneity versus cultural diversity, private versus public spheres, and belief versus disbelief. The question of sport and religion (including Islam) is also shaped by how these discourses affect other debates such as accommodating sport to religious needs (or vice versa), and access to public funding and sport facilities by Muslim communities [1, 2]. There have been a number of questions raised in Europe, and more recently in Canada (particularly in Quebec), around the use of tax money to fund sport projects targeting Muslim communities 
only; the expression of religiosity, for instance wearing the veil (or even the turban for Sikhs); and the issue of sport practice in schools in a mixed gender environment [3].

Muslims in the West are facing multiple dilemmas concerning the complexity of combining multiple identities: a sense of belonging to the Ummah (the global community of Muslim believers) and a sense of belonging to host societies or countries of birth. They are under pressure more than ever to demonstrate their loyalty to Islam on the one hand, and to their nationality/citizenship on the other. Jocelyne Césari explains this complex variety of belonging(s) as the contradiction between individual, collective, and national identities. These complex, and for some contradictory, layers of identity are being felt in the domain of sport, particularly in football and in events such as the FIFA World Cup and the summer Olympics. Demands are being made by Muslim communities - in the name of democracy, citizenship, and rights to cultural and religious differences - to accommodate specific times for Muslim women and young girls at local leisure centres, to allow men to wear long swimming trunks in public swimming pools, and to allocate specific training/nutrition programmes for professional athletes to meet their religious duty of fasting during the month of Ramadan. For Muslim Europeans, sport is another field to explore (or to "conquer") in order to reconcile their multiple identities. For conservative-nationalist movements and states authorities in Europe, sport is another public (secular) space to safeguard from the over-expression, or over-visibility, of Islamic identity in Europe [4].

In terms of structure, the paper will first discuss the question of religious phenomena in Europe in relation to the debate of cultural diversity, ethnicity, and citizenship rights. The second part of the paper examines the question of Islam and Muslims in the West in general and in France in particular. The last part of the paper reveals examples of tensions around Islam and Muslim communities in the domain of sport. The media portrayal of athletes of Muslim background in the country of birth or citizenship, but also in the country of origin, are used as illustrative examples of the crisis of meanings today around Muslim faith and culture in Europe.

\section{Religious Phenomenon in Europe: "Ritual" versus "Cultural," "Particular" versus "Universal"}

According to Alain Touraine:

What is new today, is that groups previously defined on the basis of their nationality, ethnicity or religion, which had existed only in the private sphere, are acquiring today a public existence so strong that it risks damaging their belonging to a national society...(this is taking place) whilst we are witnessing the weakening of national communities and the strengthening of ethnic communities ([5], p. 235, translated from French).

In Touraine's terms, we should not confuse the tendency toward cultural plurality, linked to growing international migration, with communautarisme, ${ }^{1}$ defined in the strictest sense by the

\footnotetext{
Communautarisme is defined as anti-liberalism doctrine. The concept is mainly applied in France relation to the high visibility of Islam in the public domain (praying in the streets, the provision of halal meals in school and in the market, or wearing the veil in public offices) which for some is not compatible with, and perhaps even poses a threat to, the republican values (or republicanisme) and cohesion within the French national community.
} 
power of the ruling group in imposing practices and internal restrictions on their community members, which in Touraine's terms "usually takes the form of a rejection of everything that is foreign." In this sense communautarisme, which is commonly used in France to refer to the self-segregation of certain communities, defines itself in opposition to citizenship, limiting the civic rights of men and women and therefore contradicting the political rights of individuals. Touraine here prefers to refer to "cultural rights" (the particular), which are positively linked to (and do not contradict) "political rights" (the universal). Moreover, as argued by Touraine, "cultural rights," like "social rights," can become anti-democratic and even totalitarian instruments if they are not closely connected to "political rights," which are universal. Touraine [6] concludes:

Multiculturalism does not mean the endless fragmentation of cultural space, and it is not a world-wide cultural melting pot. It is an attempt to reconcile the diversity of cultural experiences with the mass production and distribution of cultural goods... No multicultural society is possible unless we can turn to a universal principle that allows socially and culturally different individuals and groups to communicate with one another ([6], pp. 166-67, translated from French).

It should be noted here that Touraine strongly believes in modernity as the only possible platform for a cross-cultural dialogue between those societies that have reached modernity and those that have certain elements of modernity but have yet to fulfill their modernisation. Accordingly, Touraine asserts that "the Other has to be recognised as such, as different, only if the same Other, as myself, accepts the universal principles which define modernity" ([5], p. 263). This is problematic when we know the role that modernity and the European Enlightenment played in reducing religion to its cultural expression in the private sphere. The intellectual disqualification of religious reason in the past by scientific reason (at least in its anti-clerical version) ${ }^{2}$ has contributed to what Mohammed Arkoun [7] describes as "the generalisation of a culture of disbelief" in western societies. This is even more problematic for Islam, which does not disassociate between the ritual, the moral, and the law (the dimensions of Islamic legality), on the one hand, and between the public and the private spheres on the other. Oubrou explains:

The fact that the Koran tackles the principle of sanction, responsibility, obligation of laws as regards to family...it means that Islam is interested in the supervision of life in society and community. It is thus a foundational principle in the existence of an Islamic law ([8], p. 130, translated from French).

For Tariq Ramadan, "whether we like it or not, the essence of Islam is religious":

The central principle of tawhid, which we have often referred to, the foundations of faith and practice, the general guidance we find in the scriptural sources, leave no room for doubt about the reality of this. To speak of Islam is first of all to speak of faith, spirituality, and ethics, which together make up a conception of humankind and of life (...). Around the body of principles that define the fundamentals of allegiance to Islam, the area of social affairs is a field that is open to the cultures, customs, discoveries, and creativity of human kind as long as they do not violate a prohibition that is specific and explicit and recognised as such ([9], p. 214).

2 So called 'tele-techno-scientific' is spreading a new pragmatic instrumental form of reasoning led by the principle of 'just do it', as long as so doing ensures concrete, significant technological and economic success. 
Notwithstanding the dominance of secular discourse in science, politics, and the media, many commentators agree that there is a global resurgence or revitalisation of religious movements, including Islam, which started according to Martin Riesebrodt in the 1970s [10]. Jürgen Habermas recognises that we are in "post-secular" epoch. In his article "Notes on a Post-Secular Society," Habermas asks about the current place of religion in Europe, how we should see ourselves as members of a post-secular society, and what must we reciprocally expect from one another in order to ensure that in firmly entrenched nation-states, social relations remain civil despite the growth of a plurality of cultures and religious world views. To answer these questions, Habermas proposes that a distinction should be made between "secular" and "secularism":

Unlike the indifferent stance of a secular or unbelieving person, who relates agnostically to religious validity claims, secularists tend to adopt a polemical stance toward religious doctrine that maintains a public influence despite the fact that their claims cannot scientifically justified.

Habermas goes on to describe the main features of "post-secular" modern societies as follow:

- The awareness of living a secular society is no longer bound up with the certainty that cultural and social modernisation can advance only at the cost of the public influence and personal relevance of religion.

- Religion is gaining influence not only worldwide but also within national public spheres. Churches and other religious organisations are increasingly assuming the role of "communities of interpretation" in the public arena of secular societies:

They can attain influence on public opinion and will-formation by making relevant contributions to key issues, irrespective of whether their arguments are convincing or objectionable... Let me remind you that the visibility and vibrancy of foreign religious communities also spur the attention to the familiar churches and congregations. The Muslims next door force the Christian citizens to acknowledge to the practice of a rival faith. And they also give the secular citizens a keener consciousness of the phenomenon of the public presence of religion [11].

\section{3. 'Islam' and 'Muslim identities' in the West}

According to Arkoun, the imposition of positivist scientific knowledge, which happened in Western society in the name of secularism (or laïcité in France), liberalism, and socialism, has 'discredited' or 'eliminated' religion in society without providing an adequate alternative as a symbol of human existence and a source of unifying ethical values for the group [12].

One can argue, however, that despite the apparent triumph of secularism, the division between the transcendent and the temporal is not always explicit. Sometimes the Judeo-Christian tradition of Europe is used as an argument to justify the incompatibility between Islam and European culture. ${ }^{3}$ Secularism means different things in different national contexts. The same is true for the relationship between the state and religion (including Islam). Regarding this point, Césari asserts that the relationship of the government to religion in Europe, and thus the institutionalisation of Islam, tends to pattern itself on one of three principles: cooperation between church and state (Austria,

3 For example, debates surrounding the question of Turkey's integration into the EU. It is worth noting here that Turkey is accepted as part of the European space in sport but not in cultural and political spaces. 
Belgium, Italy, Spain, and Germany); the existence of state-sponsored religion (Great Britain, Denmark, and Greece); or the 'total' separation of religion and politics (the case of France) [4].

The second source of incomprehension about the 'others' (i.e., Islamic faith and Muslims culture) lies in what Said refers to as Orientalism [13]. The construction of Islam, in the Western/collective imagination, is argued to be a product of opposition between, or in contrast to, the East/Orient/Islam on one side, and the West/the Occident/Christendom on the other. As a result of this antagonistic differentiation, Islam and the 'Orient' as depicted in the West have been reduced to a set of references and characteristics, linked to "a collective fiction" which sees the 'Orient' as a place of 'violence,' 'superstition,' and 'irrationality' [14].

The third cause of incomprehension lies in the discourse on identity (of 'we' and 'others') in the so-called era of globalisation, which has increased, according to Habermas (cited in Borradori, 2003), the sense of fear of "the violent uprooting of traditional ways of life." The tendency toward an exclusive-oriented approach to identity within 'immigrant' communities, but also within 'non-immigrant' national minorities, has also been reinforced by the absolutist discourse of nationalist populist movements. The discourse of exclusion, fueled by fear from increasing migrant flows, has been used by nationalist parties across Europe to portray the foreign 'others' (ethnic minorities, religious communities, refugees, and asylum seekers) not only as guilty by virtue of their "foreignness," but also by their cultural heritage [14].

The other aspect in this crisis of meanings is in the dialectic of Muslim 'authenticity.' Who is an 'authentic Muslim' and who is not? The Muslim community, at least for those accepting to be categorised as such due to their cultural background or their religious worldview, can be divided in relation to the question of authenticity (negotiated in relation to the Quranic fact and the authentic tradition of the prophet and his companions and early followers) into mainly six groups (see Table 1). To add to these six groups there is a growing minority represented by Western-converted Muslims, defined by Jean-Paul Charnay [15] as European neo-Muslims, which he distinguishes from Muslim neo-Europeans representing the second and third generations of Muslims in Europe.

One should also distinguish between Islam as a religion, and what Ahmed Akbar refers to as Muslims' responses to the forces of globalisation, actions, and strategies that Muslims are adopting as a result of their current political or economic situations as a minority in non-Muslim societies. Akbar categorises these responses into "accepting" (reaching out to other faiths), "preserving" (traditionalists), and "synthesising" (synthesising with other non-Muslim and secular systems) [16]. To illustrate the different strategies that Muslims adopt in mobilising Islam (or not) as a frame of reference, Mandville provides the following example:

There are a good number of Muslims involved in social and political movements who take the pursuit of goals and agendas defined in terms of Islamic normativity (interpreted in widely varying ways) as their primary raison d'être. Likewise, there are also many Muslims whose public identities under most circumstances are not constructed in reference to Islam, but who - under certain conditions-may mobilise themselves around Islam as a form of political expression ([17], p. 493).

The last component in the crisis of meanings is Occidentalism. In opposition to Orientalism, another form of exclusivism has emerged, namely 'radical Islamism,' which purports to be the sole 'owner' of Islam and which builds its identity exclusively in relation to the 'other,' 'evil,' 'atheist,' 'imperialist,' 'fashion-addicted,' 'selfish,' 'morally corrupt' West, as the (sole) cause of 'our' 
(Muslim societies) decadence. This dehumanising picture of the West is characterised as the root of anti-Western sentiments [18].

Table 1. Muslim identity and Islamic 'authenticity' in the West ([15], p. 21).

\begin{tabular}{|c|c|}
\hline Ritualised Islam & $\begin{array}{l}\text { Islam of grandparents (first generation of immigrants) the holder of traditions } \\
\text { in the family. Visible during religious celebrations and in dress codes. } \\
\text { Authenticity is defined in relation to Islamic practices of the country of origin. } \\
\text { Islam as a spiritual ethos. }\end{array}$ \\
\hline Nati & $\begin{array}{l}\text { The official Islam of the country of origin represented by the ministry of } \\
\text { religious affairs and its delegate in Europe. } \\
\text { Islam in the service of state (secular) ideology (Moroccan, Turkish, Algerian) } \\
\text { and source of legitimacy for the political order (nation-state, economic, } \\
\text { cultural and social projects). }\end{array}$ \\
\hline Traditionalists & $\begin{array}{l}\text { Preached by Islamic centres of jurisprudence (Mecca, Medina, and El-Azhar } \\
\text { for Sunni communities, and Nadjaf and Qum for Shi'a communities). }\end{array}$ \\
\hline Reforn & $\begin{array}{l}\text { Seeking to Interpret Islamic orthodoxy in relation to the European context. } \\
\text { Represented in Europe by The European Council for Fatwa and Research; } \\
\text { Muslim's Executive of Belgium, Islamic Commission of Spain, French } \\
\text { Council of Islam. }\end{array}$ \\
\hline $\begin{array}{l}\text { Neo-traditionalists } \\
\text { (anti- modernist) }\end{array}$ & $\begin{array}{l}\text { Rejects what is seen as the corrupted Islam of both ritualised Islam and } \\
\text { Nationalist Islam. Demanding the right to preserve cultural differences (or } \\
\text { differentiation) in the name of multiculturalism and in reference to the Umma } \\
\text { (nation of believers). }\end{array}$ \\
\hline Neo-re & $\begin{array}{l}\text { A European Islam (Muslim - believers - and citizens). Calling for a rupture } \\
\text { with Nationalist (society of origin) Islam. Islam as an opportunity for good } \\
\text { citizenship in Europe. }\end{array}$ \\
\hline Secular & $\begin{array}{l}\text { A cultural belonging to the Islamic religion (part of the private sphere). Refuse } \\
\text { to be branded as Muslims in their everyday social relations. A sign for them of } \\
\text { a communautarisme, getthoisation, and ethnification of Europe. }\end{array}$ \\
\hline
\end{tabular}

\section{Sport and Muslims in Europe: Case Study of France}

According to Pew Research data from 2010 on religion in Europe, the number of Muslims in Western Europe has reached 11.3 million. The Muslim share of Western Europe's total population is expected to increase from $6.0 \%$ in 2010 to $8.6 \%$ in 2030 [19]. In the absence of census data for ethnicity and religious affiliation, Islam is considered to be the second largest religion in France. Although it is hard to get a precise picture about the number Muslims in France, including French citizens of Muslim heritage and other Muslim residents, it is commonly accepted that their number is around five to six million (8\%-9.6\%), the majority of whom are of North African origin (Algeria, Tunisia, and Morocco, known as the Maghreb). The rest are mainly from sub-Saharan Africa and Turkey.

Islam, as the "second largest religion following Catholicism," often finds itself at the heart of the debate in France about national identity, secularism, migration, national security, and riots in the suburbs (the banlieues or underprivileged housing estates). As described by Césari: 
Too often discussions about Islam in France begin and end with a treatment of Muslims as a social problem. Too often the question is asked: Can Muslims fit into French society? That question presupposes that Islamic values are inherently incompatible with western ones and that Muslims constitute a "dangerous class" [20].

The French republican reassertion of the need to conform to the non-religious nature (known as laïcité) of the state has been reinforced by the ban on wearing of religious symbols in schools. Such a ban on public displays of religious affiliation also implies that such dress or religious symbol would be unacceptable in public sector sports facilities and services. As a consequence, the questions of the veil and the demand by members of the Muslim community for women only swimming hours at municipal swimming pools are becoming the centre of electoral campaigns. This is to measure the loyalty of candidates for different elections at local and national levels to the French republican value of laïcité. Martine Aubry, previously the head of the socialist party and the mayor of Lille, was highly criticised for allowing the allocation of specific time for women (mainly Muslim) in a public swimming pool [21]. She and the socialist party have been accused by conservative party and far right movements of seducing electorates among Muslim communities at the determent of secular values of France and its assimilissionist/republican model.

Having described the general context about the debate on Islam in France, we will explore in the subsequent section some of the emerging discourses that characterise media depictions of the question (or the problem) of Islam and/in sport. A number of recent events in France are worth exploring from a sociological, political, and media perspective in order to make sense of the debates on sport in relation to wider societal issues such as the politics of identity or questions of integration, and diversity and laïcité in France and its former colonies in North Africa.

\section{1. "Moderate" versus "Radical” Islam}

In an interview with a French radio station, the philosopher Alain Finkielkraut asked the following question about French residents of North African background: What do they think of France? He noted:

We have the impression that the imaginary identity is Algerian and France is just an insurance company, and at most, an object of execration. It is for this reason that the campaign of French identity is a success in France. Some say that such affirmation of identity is exclusionary. No! We invite all French citizens to share this identity and there are some who aggressively and firmly reject it. ([22], translated from French)

Media coverage and political commentaries around selected incidents are symptomatic of the crisis of meanings, which we explained earlier about Islam and Muslim identities in Europe in general and in France in particular. The first incident occurred during the final of the 2006 FIFA World Cup in Germany between France and Italy. Zinedine Zidane's famous headbutt of Marco Materazzi, a global media event par excellence, witnessed by millions of spectators, was explained as being the by-product of a 'clash of civilizations.' On the one hand, Zidane, with his Algerian immigrant origin, somehow represents the Muslim World. He grew up in a suburb of Marseille, which is known for its multicultural population. On the other hand, Metarazzi, the Italian player, was representing 'the West.' Zidane's reaction was explained in orientalist fashion as 'irrational' 


\section{6}

and symptomatic of his 'hyper-masculine' North African culture and the delinquent-like culture of les banlieue or suburban zones of Marseille [23]. Similarly Jiwani contends that French coverage of the incident reproduced "Orientalist frames (animal imagery, violence, and irrationality) but also underscored associations between Muslims and terrorists in its speculations regarding what Marco Materazzi had said to provoke Zidane's actions" ([24], p. 1).

The second incident occurred during the friendly match between Tunisia and France on 14 October 2008 in Stade de France. France's national anthem, La Marseillaise, sung by Lââm, a French female R\&B singer of Tunisian origin, was booed by some in the crowd. This scandalised and even enraged French politicians, particularly those from the center-right majority, led by President Sarkozy, who not only asked for an investigation into the matter, but also requested that measures be put in place to prevent the reoccurrence of such an event in French territory. Some of the measures presented in response to this demand stipulated that all friendly games with the country concerned are to be suspended for a period determined by the president of the federation or, even more drastically, that France should no longer play friendly matches against countries from the Maghreb region. Of course, this incident was an occasion for some in political, football, and intellectual circles to question the loyalty of the Maghrebi community (Tunisian, Algerian, and Moroccan) to the French nation and its values. When asked by the media to comment on the incident, Hatem Ben Afra, born in France of Tunisian parents and later a member of the French national football team, declared: "it's a bit of a shame but it's not a major problem. They need to exist, you have to understand them" [25].

The third incident was during the 2010 FIFA World Cup in South Africa. In the midst of the scandal of the French football team, the image of Franck Ribéry's wife, with her Algerian flag and t-shirt displaying the slogan 'Yes, We Can' in support of the Algerian national team, was at the centre of another polemic in France. Her loyalty to France, and thus the loyalty of her husband (a Muslim convert), were put in doubt. In her campaign to replace her father, Jean-Marie le Pen, as the new leader of the far right National Front Party, Marine le Pen declared:

Most of these people think that one day they can represent France in the World Cup, and another day they can consider themselves to be from another nation or to have another nationality [...] if they behave correctly [...] if we sometimes hear about patriotism from these players, if it happened that some of them do not refuse to sing La Marseillaise, and they do not take on the flags of other countries, maybe things will change. But currently, I do not particularly recognize myself in this team. ([26], translated from French)

The misconduct in South Africa of some players, such as Nicolas Anelka and Franck Ribéry (both Muslim converts) was portrayed in the media and within political circles as a product of the "violent", "non-French", and "non- republican" culture of suburbs that are mostly populated by French of immigrant decent and particularly of North African origin. This was re-emphasised in the intervention of the French Minister of Health and Sport, Roselyne Bachelot, during a parliamentary debate about the French National Team:

The government should never have had to get involved in the World Cup, but you have all seen the disaster that resulted from immature thugs leading frightened players, a coach without authority, and a federation that's out of its depth. That's why the government has decided to take charge [27]. 
Finkielkraut, the French Philosopher, went a step further by explaining, yet again, the reasons behind the fiasco of the French team in South Africa: "the French team suffers from ethnic and religious divisions... it is a team of hoodlums... with mafia ethics... a team of people that doesn't care about France" [28].

In light of the media pressure to protect the secular values of the French Republic within the national football team, particularly after the bad publicity of Les Bleus in South Africa, Lauren Blanc, the new appointed coach, declared in an interview that halal meals will not be provided at the national performance centre or during training camps [29].

\subsection{Living in between}

When asked about their identities either in their country of birth or country of origin, athletes from immigrant backgrounds are torn between a symbolic connection and a deeper connection with the country of origin. This is exemplified by a statement made to the media by Djamel Bouras, the French judoka (from an Algerian background) and a gold medal winner in the 1996 Atlanta Games: "What does it mean: French Jews, Arabs... who are the Arabs? Am I Arab or French? I am French Muslim!" ([30], translated from French). ${ }^{4}$

For some French citizens of immigrant origin, sport (particularly soccer) is an occasion to celebrate their double sense of belonging to a 'hybrid' identity - that is, an amalgam of aspects of migrant culture and French citizenship, expressed neither in terms of fully belonging to 'French culture' nor in terms of belonging to the 'culture of origin.' However, due to the sentiment of being marginalised in their country of birth or to improve their international career, other athletes from immigrant decent choose to represent their country of origin at international sport arena. This is evident in the steady increase in the number of third-generation young players from immigrant communities in North African national teams (Tunisia, Morocco and Algeria). If we take the example of Algeria, the number of players with an immigrant background participating on the Algerian national football team has increased. This increase has been facilitated by the new FIFA rules. ${ }^{5}$ These players are principally from France and Belgium, which are known for high concentrations of residents with Algerian immigrant origins, but also from other countries such as Holland, Denmark, and Canada. One can argue that, for these athletes, participating with the Algerian national team represents a unique opportunity to compete at international level. The same pattern can be seen in other North African countries and in the Middle East, particularly in Palestine and Lebanon, which have large immigrant communities in Europe and North America [31].

The reintegration of top athletes into the national team of their parents' country of origin is not always celebrated in a positive way. In addition to the fact that these players are subjected to criticism in their countries of birth, as discussed earlier, their identities and loyalties are also questioned in the country of origin, particularly when the performance expected from them is not

4 It was reported that after winning the gold medal in Atlanta, Djamel Bouras offered the medal to "all Muslims who suffer in the world." This provoked a number of comments in mainstream media and in social media about his ideology. He was even accused by extreme right circles of being pro-Palestinian Hamas and pro-Lebanese Hezbollah.

5 The example of Rais Mblouhi, the goal keeper of the Algerian national football in the 2010 FIFA world, born in France to a Congolese father and Algerian mother. 
there. The Algerian national team that qualified for the 2010 FIFA World Cup in South Africa, after 24 years of absence, was depicted as 'the other French team.' They were asked to prove more than other players their loyalties to the Algerian flag and to demonstrate their Algerian "male aggressiveness" during the competition and their faithfulness to Islamic morality (for instance abstaining from alcohol). The fact that some players tinted their hair blond for the opening group game between Algeria and Slovenia was severely criticized in the Algerian media and was described as 'non-Algerian,' 'non-Arab' (Algeria being the only Arab country in the competition), and even 'non-Islamic.' To counter these stereotypes and to affirm their attachment to Islamic morality players make Sujud (prostrations) after scoring a goal [31].

Top athletes who choose to compete for their country of birth are still celebrated as 'ambassadors' of their country of origin, and their performance is explained as a direct product of the creativity, courage, and intelligence they inherited from their culture. Zidane, Samir Nasri, and Karim Benzema have been praised for their 'Algerian,' Ben Arfa for his 'Tunisian,' Ibrahim Afellay and Khalid Boulahrouz for their 'Moroccan' style of football; Mehdi Baala - a French middle-distance runner-for his natural 'North African' ability to run. By contrast, in their country of birth, these athletes' performances are explained as a direct result of (Western) discipline, rational and strategic thinking and socialization (de-culturation) in schools. However, sometimes the Western culture of these top athletes is not well accepted in their country of origin. Sometimes, these players are even deemed heretics. A Tunisian newspaper, Attounisia, published a revealing picture of a TunisianGerman player, Sami Khedira, with his model girlfriend, Lena Gercke. The photograph generated a state of shock in Tunisia. Mass demonstrations, led particularly by the Salafi movement, were organised in the country. As a result, three journalists from the newspaper were taken into custody and charged for offending public morality. This is happening while Tunisia is undergoing a political transition and societal transformations characterised by the resurgence of religiosity (tadayoun) after more than three decades of secular rule under Bourguiba and Ben Ali. Following international pressure, the charges against the journalist were dropped, but the incident sparked a national debate in the country about the limits of freedom of expression and morality [32], as well as the debate on national identity in the post-Ben Ali era.

\section{Conclusions}

Sport is at the centre of the debate on integration and national identity of immigrant communities in Europe, and since 9/11 the debate is now centered on immigrants of Muslim faith or culture. For Muslim athletes sport, and particularly football is a terrain for identity making and resistance against stigma. The incidents in sport involving Muslim athletes is an occasion for the supporters of a clash of cultures to exacerbate existing ethnic tensions in cases that involve athletes of immigrant and Muslim backgrounds, mixing thus in their interpretation aspects of "violence, Islam, and masculinity."

For Muslim athletes, playing for their country of origin is an occasion to reconnect with Islamic culture, or at least Islamic spirituality, and to support important causes of the global Muslim community (Ummah). The example of Frédéric Omar Kanouté, French of Mali origin and professional footballer with Seville FC, who was fined 3000 Euros by the Spanish Football Federation for revealing a T-shirt displaying a pro-Palestinian slogan. Similar to Kanouté, more top 
professional footballers in Europe are celebrating their Muslim identity in public. This, in turn, creates tensions with regards to competition and fasting during Ramadan or sponsorship of football clubs by alcohol and betting companies [33]. ${ }^{6}$

Some media and intellectual commentators explain public expressions of religious identity in France, including in sports, as a means of defying France's secular republican values. Such explanations accompany incidents ranging from providing halal meals in football training camps to Djamel Bouras's gesture of offering his Olympic gold medal to "Muslims around the world." These same commentators frequently interpret public expressions of religious identity in sports as symbols of religious awakening and the 'Islamisation' of French suburbs. "The religious belief is more structured than the belief in republican values," wrote Le Monde (October 4, 2011) after the 2011 riots to explain the phenomenon of "cultural re-islamisation "or "intensification of religious practice" among Muslims in France [34].

Sport is becoming the space to test the success of "integration" policies of minorities into the host society and to question the loyalty of Muslim minorities to the "host" nation. Muslims of immigrant origin are caught between affirming their (multiple) identities while avoiding and combating stigmatisation both in their country of birth and country of origin.

\section{Conflicts of Interest}

The author declares no conflict of interest.

\section{References}

1. Kirstin Walseth. "Young Muslim Women and Sport: The Impact of Identity Work." Leisure Studies 25 (2006): 74-94. doi:10.1080/02614360500200722.

2. Mahfoud Amara, and Ian P. Henry. "Deconstructing the Debate around Sport and the 'Question' of 'Muslim Minorities' in the West'. In Islam in the West: Key Issues in Multiculturalism. Edited by Max Farrar, Simon Robinson, Yasmin Vallic and Paul Wetherly. London: Palgrave, 2012, pp. 138-53.

3. Mahfoud Amara, and Ian P. Henry. "Sport, Muslim Identities and Cultures in the UK, an Emerging Policy Issue: Case Studies of Leicester and Birmingham." European Sport Management Quarterly 10 (2010): 419-43. doi:10.1080/16184742.2010.502743.

4. Jocelyne Césari. When Islam and Democracy Meet: Muslims in Europe and in the United States. New York: Palgrave, 2004.

5. Alain Touraine. Un Nouveau Paradigme: Pour Comprendre le Monde Aujourd'hui. Paris: Fayard, 2005.

6. Alain Touraine. Can We Live Together? Equality and Difference. Cambridge: Polity Press, 2000.

7. Muhammed Arkoun. The Unthought In Contemporary Islamic Thought. London: Saqi Books, 2002.

8. Leila Babes, and Tariq Oubrou. Loi d'Allah, loi des Hommes. Paris: Albin Michel, 2002.

6 According to BBC documentary on Muslims in the Premier league there are nearly 40 Muslim players in the English Premier league. 20 years ago there were none. 
9. Tariq Ramadan. Western Muslims and the Future of Islam. London: Oxford University Press, 2004.

10. Martin Riesebrodt. "Fundamentalism and the Resurgence of Religion." Numen 47 (2000): 266-87. http://www.jstor.org/stable/3270326.

11. Jürgen Habermas. "Notes on a Post-secular Society." Signandsight.com, 18 June 2008. Available online: http://www.signandsight.com/features/1714.html (accessed on 1 September 2010).

12. Mouhamed Arkoun. "Rethinking Islam Today." Annals of the American Academy of Political and Social Science 588 (2003):18-39. http://www.jstor.org/stable/1049852.

13. Edward Said. Orientalism. London: Penguin, 1977.

14. Jocelyne Césari. Musulmans et Républicain: Les Jeunes, l'Islam et la France. Paris: Editions Complexe, 1998.

15. Jean-Paul Charnay. “Que devient une religion réduite à l'observance rituelle?” Oumma.com, 26 May 2000. Available online: http://oumma.com/Que-devient-une-religion-reduite-a (accessed on 5 November 2005).

16. Ahmed Akbar. Journey into Islam, The Crisis of Globalisation. Washington: Brookings Institution Press, 2007.

17. Peter Mandville. "Muslim Transnational Identity and State Responses in Europe and the UK after 9/11: Political Community, Ideology and Authority." Journal of Ethnic and Migration Studies 35 (2009): 491-506. doi:10.1080/13691830802704681.

18. Ian Buruma, and Avishai Margalit. Occidentalism: The West in the Eyes of its Enemies. New York: Penguin Books, 2004.

19. PewResearch. "The Future of the Global Muslim Population." 2010. Available online: http:/www.pewforum.org/2011/01/27/future-of-the-global-muslim-populationregional-europe/\#ftn35_rtn (accessed on 1 September 2013).

20. Jocelyne Césari. "Islam in France: The Shaping of a Religious Minority." In Muslims in the West, from Sojourners to Citizens. Edited by Yvonne Haddad-Yazbek. London: Oxford University Press, 2002, pp. 36-51.

21. Michel Veron. "Aubry a-t-elle vraiment réservée des créneaux de piscine à des musulmans." L'express Magazine, 30 March 2012. Available online: http://www.lexpress.fr/actualite/politique/ aubry-a-t-elle-vraiment-reservee-des-creneaux-de-piscine-a-des-musulmanes_1098551.html (accessed on 1 December 2012).

22. Ugo Palheta. "Coupe du Monde: Alain Finkielkraut moralise le football." ACRIMED, 24 June 2010. Available online http://www.acrimed.org/article3400.html\# (accessed on 23 September 2012).

23. Pascal Duret. "Perception du « coup de Boule » de Zidane par les collégiens." Socio-Logos. Revue de l'association Française de Sociologie 2, 2007. http://socio-logos.revues.org/171.

24. Bruce Crumley. "Booing the Marsellaise: A French Soccer Scandal." TIME Magazine, 15 October 2008. Available online: http://www.time.com/time/world/article/0,8599,1850831,00.html (accessed on 1 March 2011).

25. Le Point Magazine. "Marine Le Pen: 'Certains joueurs de l'équipe de France ont une autre nationalité de cœur'.” 3 June 2010. Available online: http://www.lepoint.fr/societe/reaction- 
marine-le-pen-certains-joueurs-de-1-equipe-de-france-ont-une-autre-nationalite-de-coeur-0306-2010-462559_23.php (accessed on 10 October 2012).

26. Dan Baynes, and Gregroy Viscus. "French Team Faces Fight to Improve Its Image after World Cup 'Disaster'." Bloomberg Online, 23 June 2010. Available online: http://www.bloomberg.com/news/2010-06-22/french-team-faces-fight-to-improve-its-image-afterworld-cup-disaster-.html (accessed on 15 October 2012).

27. Robert Marquand. "France's World Cup Soccer Woes Rock French society." The Christian Science Monitor, 22 June 2010. Available online: http://www.csmonitor.com/World/Europe/ 2010/0622/France-s-World-Cup-soccer-woes-rock-French-society (accessed on 20 September 2011).

28. Feteh Mezzener. "Les joueurs musulmans de l'équipe de France de foot mangent-ils réellement Halal?" Oumma.com, 12 June 2012. Available online: http://oumma.com/13059/ joueurs-musulmans-de-lequipe-de-france-de-foot-mangent (accessed on 13 October 2012).

29. Bénédicte Charles. "Incroyable mais vrai: Avec Domenech, c'était halal pour tous les bleus!" Marianne Magazine, 8 September 2010. Available online: http:/www.marianne.net/ Incroyable-mais-vrai-avec-Domenech-c-etait-halal-pour-tous-les-bleus-_a197168.html (accessed on 15 January 2012).

30. Karam Saër. "Djamel Bouras: Le combattant de la vérité." La Revue du Liban, 20 January 2001. Available online: http://www.rdl.com.lb/2001/q1/3775/bouras.html\# (accessed on 10 June 2013).

31. Mahfoud Amara. Sport, Politics and Society in the Arab World. London: Palgrave and Macmillan, 2012.

32. BBC. "The Muslim Premier League." BBC Documentary, broadcasted on 9 July 2013 (duration $30 \mathrm{~min}$ ). Available online: http://www.bbc.co.uk/programmes/b036qfqc (accessed on 9 July 2013).

33. Jill Reilly. "Publisher arrested in Tunisia after printing GQ cover of German footballer covering naked WAG's breasts with his hands." Daily Mail, 24 February 2012. Available online: http://www.dailymail.co.uk/news/article-2105892/Publisher-arrested-Tunisia-GQcover-German-footballer-Sami-Khedira-covering-Lena-Gerckes-breasts.html\#ixzz2ZDpNcyf6 (accessed on 15 September 2012).

34. Luc Bronner. "La place croissante de l'islam en banlieue." Le Monde, 4 October 2011. Available online: http://www.lemonde.fr/societe/article/2011/10/04/banlieues-de-larepublique_1581976_3224.html (accessed on 10 September 2012). 


\title{
Majority versus Minority: 'Governmentality' and Muslims in Sweden
}

\author{
Anne Sofie Roald
}

\begin{abstract}
This article deals with the Muslim community in Sweden in view of the majority-minority dynamics with focus on how values, attitudes, behaviors, and practices of the Swedish majority influence Muslim minority communities and how majority society's approach to Muslims and Islam influences both the relationship Muslims have with non-Muslims and the understandings that Muslims have of Islam.
\end{abstract}

Reprinted from Religions. Cite as: Roald, A.S. "Majority versus Minority: 'Governmentality' and Muslims in Sweden." Religions 4 (2013): 116-131.

\section{Introduction}

The 'clash of civilizations' thesis was much debated in the 1990s. Promoters of the thesis regarded the 9/11 attacks as a confirmation of its truth. Whether intended by Huntington or not, the thesis came, particularly after the 9/11 attacks, to be a depiction of the struggle between 'the Islamic' world and 'the Western secularized' world. It is thus pertinent to ask whether this Al-Qaida attack on US economic and political symbols of power was really a clash between these two 'civilizations'? It seems more plausible to analyze this violent event in view of other factors. First, there is the globalization of the media which boomed in the 1990s, particularly with the spread of satellite television. Until 1996, the Arab world had strict national censorship for the distribution of news. With the launching of the satellite Arab-medium TV-channel Al-Jazeera, most Arab-speaking families got access to news from all over the world as well as to critical political analyses of their own political leadership and of the relation between 'the West' and 'the Rest'. It seems thus that political rather than civilizational factors better explain 9/11 and its aftermath.

A second political factor in the conflict between 'Muslim regions' and the 'secularized West', at least until the Arab uprising of 2011, was the US and European support for dictators in the Arab world, including Hosni Mubarak, Saddam Hussein, Ben Ali, and Muammar Gaddafi. This support of the Arab elite left the political opposition in a state of powerlessness, creating a notion of Muslims as a global powerless minority versus the 'West' as a global powerful majority.

A third important factor, cultural rather than political, was and is the globalization of the 'Western' entertainment culture. As it is the 'low culture' rather than the European classical culture which is spread all over the world, the Muslim consumers in particular have the impression of a 'Western' degenerating culture with sex and violence as the main ingredients. With the growth of satellite television and the Internet in Muslim regions, the entertainment industry has taken a hold 
of Muslim youth. Islamist resistance to 'Western cultural imperialism' is incorporated into a general political resistance against a global powerful majority, 'the West'.

The 'clash of civilizations' thesis in terms of the 'Islamic' versus the 'Western secularized' world seems to be less a clash between two big civilizations and more a conflict between groups identifying themselves with one or the other of these two 'civilizations' who tend to fight against 'the others' either orally or by physical violence. This global conflict has saturated the public debate in many receiving countries, and Muslims have to a great extent become 'the immigrants'. To link the global struggle to the relationship between majority societies in the West and the Muslim immigrant minorities, it is important to regard the situation in each country with Muslim immigrants within a pattern of a dynamic interaction between majority and minorities.

\section{Case-Study: Sweden}

As shown above, it is important to look at various aspects of the relationship between Muslims and non-Muslims in order to understand its complex dynamics. Within nation states in today's receiving countries it is important to analyze religion (or anti-religion), ethnicity, majority versus minority aspects, etc, in order to estimate the relevance of Huntington's conflict theory in each nation state. This study will focus on one aspect of this complex issue, namely the majority-minority dynamics. How do the values, attitudes, behaviors, and practices of the majority influence minority communities in a given country? This article takes Sweden as a case study in order to examine how the majority society's approach to Muslims and Islam influences both the relationship Muslims have with non-Muslims and the understandings that Muslims have of Islam. The main presupposition of this study is that the dynamics between the majority non-Muslim population and Muslim minorities shape behaviors, attitudes, and social and religious developments within Muslim communities. ${ }^{1}$

Although Sweden is the main case study, it is necessary to make some comparisons between the Swedish situation and the other Scandinavian countries, Norway and Denmark, in order to anticipate the consequences of the particular majority-minority dynamics in Sweden. Politically speaking, the three Scandinavian countries share both common political characteristics and similar public welfare service systems. But as the discussion below will indicate, these similarities do not necessarily mean that the three countries share the same political climate and value system.

Two different topics will be discussed in order to look at how the relationship between the majority non-Muslim population and Muslim minority communities influences the latter's behavior: (1) the coverage of immigrants in the media; (2) the Swedish populist party, the Sweden Democrats, and its political role. There will also be a discussion of Islamic developments in Sweden in view of the Muslim minorities' intentional and unintentional responses to majority discourses.

The empirical material in this study is mainly based on extensive fieldworks with interviews and observations in Muslim communities mainly in Sweden, but also in Norway and in Denmark, from the 1990 s onwards [1-4].

1 The majority-minority dynamics influence even developments in the majority population. However, this perspective is outside the scope of the present study. 


\section{Sweden as a Receiving Country}

In the nineteenth and early twentieth centuries, Sweden was mainly a sending country [5]. From the 1930s onwards, however, Sweden became a receiving country, with the Turkish-speaking Tartars from Finland and Estonia settling in Sweden as the first Muslim community. The Tartars established the first Islamic congregation in 1948 ([6], p. 14). Despite the increased immigration beginning in the 1940s, including the first wave of guest workers from Southern Europe, Turkey, Morocco, and Pakistan, the Swedish authorities did not have a particular immigration policy [7]. It was not until the government restricted the immigration in the mid-1970s that a particular attitude towards immigrants was launched, characterized by the words 'equality' (jämställdhet), 'freedom of choice' (valfrihet), and 'partnership' (samverkan) [8]. These buzzwords must be understood within the framework of the Human Rights declaration and of the 1966 International Covenant of Civil and Political Rights (ICCPP), ratified by Sweden in 1971. The latter states every people have the right to 'self-determination' by freely determining "their political status" and freely pursuing "their economic, social and cultural development" (Article 1). Although these rights are mainly linked to territorial majorities, Article 27 introduces the rights of minorities "to enjoy their own culture, to profess and practice their own religion, or to use their own language", thus indicating minority rights even in political and social development. This Swedish approach to immigrants in 1974 can be regarded as a forerunner to the concept of 'multiculturalism' ('mångkulturalism') and the 'multicultural society' (Det mångkulturella samhället), introduced in Sweden in the early 1990s ([3], p. 43).

The number of Muslims living in Sweden today is difficult to determine, primarily because religious affiliation is not measured in the census. A general estimation is that in 2010 there were around 400,000 Muslims in Sweden, constituting approximately 4.5 per cent of the total population [9]. A SST (The Swedish Commission for Government Support to Faith Communities) statistic from 2011 gives the number of 110,000 Muslims registered in Muslim congregations [10]. ${ }^{2}$

\section{4. 'Swedish Values'}

In Swedish public discourse, lofty ideals of democracy, individual rights, tolerance, and equal opportunities across racial, sexual, religious, gender, and age borders, are frequently promoted. In order to offer a brief overview of Swedish society, two prominent social traits, individualization and equal opportunities, will be discussed. Moreover, the notion of 'homogeneity', an underlying and implicit trait in both official policy and public space, will be examined.

\subsection{Individualization}

The Swedish individualistic approach is likely the result of the historically strong bond between the monarchy and the peasants, a bond shaped by the general absence of feudalism in Sweden [11].

2 Even this number is not reliable as some individuals might be members of more than one organization. Moreover, this number includes only those congregations registered with a Muslim National Organization. It is important to note that for instance the big mosque in Malmö, The Islamic Centre, is independent and its members are not included in the SST Statistic. 
The Social Democratic policy of the People's Home (Folkhemmet) [12], which first arose in the interwar period, might be a product of this historical trait, but whatever the case, this social model reinforced the individual trait on behalf of family bonds. Berggren and Trägårdh claim that, viewed globally, Sweden is the country where the individualization process has developed the most [13]. They argue that resources in Sweden are oriented towards the individual citizen rather than the family or organizations. Swedish society, they maintain, is based on "a social contract offering the individuals maximal liberation with minimal moral consequences" ([13], p. 74). This individualism is in contrast to the collectivistic social pattern common in many of the homelands of Sweden's Muslim immigrants, where the family, rather than the individual, tends to be the social core.

\subsection{Homogeneity}

An important aspect in the relation between Scandinavian majority society and Muslim communities is the general concept of 'equality', also one of the buzzwords in the Swedish approach to immigration in the 1970s. The concept is linked to a perception that, prior to the waves of immigration arising in the mid-twentieth century, Sweden was a strictly homogeneous society. There is a claim for conformity (this goes also for the two other Scandinavian countries) in which differences in views and appearances are regarded as problematic, and the tendency is to homogenize the Swedish majority as well as minorities through "the discursive praxis of equality" ([1]; [14], p. 186). The claim for homogeneity has to be regarded as one of the reasons of the segregated urban spaces. In immigrant-dense areas, schools have few and in some cases no 'ethnic' Swedish pupils, and meeting places between the majority and Muslim minorities are few. It is mainly through the media that various groups obtain information about each other. Due to the way that media reports often focus on that which is different and problematic as opposed to what is familiar and recognizable, the 'we' $v s$. 'them' narrative becomes reinforced in the Swedish majority as well as in Muslim minority communities.

According to Sander, Sweden has been built on the notion of "one nation, one people, one religion" ([15], p. 272). He links the segregation of Muslims in Sweden to this idea of "a common culture and religion, including common manners, norms and value system, as well as a common way of thinking in general" ([15], p. 273). One important trait in this homogenization of culture is discussed by Ehn and Löfgren. In their discussion of how elites maintain cultural hegemony, they refer to the opposing strategies of either antagonizing subcultures or incorporating cultural expressions of various sub-cultures in society [16]. In Sweden, it seems probable that the authorities, in a homogenizing manner, have largely chosen the strategy of incorporating subcultures. One example is feminism. The American scholar Joyce Gelb claims Sweden to be a country of "feminism without feminists" thus indicating an incorporation of sub-cultures into governmental policy [17]. Gelb sees this phenomenon as a problem-solving strategy in order to avoid significant conflict between the state and civil society in general, and she concludes that due to this strategy, feminist theory has not had a real impact in Sweden. It is interesting to look at her 


\section{6}

statement in view of how male Social Democratic leaders have proclaimed that they are feminists, ${ }^{3}$ even though they have failed to fight strongly for issues such as equal salary for equal jobs, a crucial claim within feminism. A similar trend can be seen on environmental issues, where more or less all political parties have incorporated parts of the environmental program of the Environmental Party (Miljöpartiet) [19]. Following Gelb, Ehn, and Löfgren, Swedish patterns of conflict resolution have incorporated parts of conflicting ideologies rather than the whole.

This claim for homogeneity might be one reason-despite the Swedish individualistic approach - that the pattern for incorporation of new groups in society is built on a corporatist membership model [20]. ${ }^{4}$ Soysal describes this model as that corporate groups, "defined by occupational, ethnic, religious, or gender identity - are emphasized as the source of action and authority" ([20], p. 37). Thus the collective identities of immigrants are stressed and through such multicultural policy the community becomes the locus for agency.

\subsection{Equal Opportunities}

The value of equal opportunities, particularly equal gender opportunities, has a strong hold on Swedish society. ${ }^{5}$ The equal gender legislation of the late 1970 s was to a great extent linked to immigration. Instead of importing foreign labor, women in general should take a more prominent role in society [23]. Already in 1971, the tax legislation had changed from joint taxation to separate taxation for married couples. This new legislation created a need for many families to have more than one salary. From a feminist perspective, this new legislation empowered women, enabling them to enter the labor market and to leave the domestic sphere where they had been subordinated to and economically dependent on their husbands.

\section{5. 'Governmentality'}

Up to the end of the 20th century, the claim for homogeneity in Sweden has been handled both through a united school system and through a united public space. The state's monopoly on

3 The Social Democratic Prime Minister at that time, Göran Persson, proclaimed that he was a feminist in January 2002, and the present Social Democratic opposition leader, Stefan Löfven stated that "I am a convinced feminist" in his inauguration speech in January 2012 [18].

4 This corporatist model has to be regarded in view of the historical growth of 'interest groups' (intresseorganisationer) in Scandinavian countries.

5 It is important to note that at least up until 2002 women have been most actively involved at the lower levels of society. The Grant Thornton Report from 2002 indicates that Norway, Denmark, and Sweden have a quite low percentage of women in management or on boards of directors. Ireland topped the list with at least one woman on $72 \%$ of its boards of directors. Norway had only 52\%; Sweden, 51\%; and Denmark, 47\%. The low scores of the Scandinavian countries are regarded as the result of the family pattern in Scandinavia, with frequent divorces, working grandparents, and few families with domestic helpers. In Ireland, divorces have been less common, most grandparents are at home helping with childcare, and domestic helpers are common [21]. See [22] for the development of equal opportunity in Swedish legislation. 
television ${ }^{6}$ as well as the strict regulations for establishing private schools made television and the public school system the means for the particular implicit power system which can be understood in the Foucaultian concept of 'governmental rationality' or 'governmentality' [25]; through socializing all citizens into particular norms and modes of action, the citizen's internalized self-governess or self-discipline ${ }^{7}$ creates a fruitful soil for a homogenous society. According to Foucault, the state's responsiveness to its 'population' (through bio-politics) is the basis for the state's prosperity, and "the aim of the modern art of government, viz., to develop those elements of individual lives in such a way that their development also fosters the strength of the state" ([26], pp. 251-52; [27], p. 10). Moreover, Foucault speaks in terms of

$[T]$ he tactics of government which make possible the continual definition and redefinition of what is within the competence of the state and what is not, the public versus the private, and so on; thus the state can only be understood in its survival and its limits on the basis of the general tactics of governmentality ([25], p. 103).

The two examples above of how Swedish prime ministers incorporate parts of feminist and environmentalist thought and practice, but not feminism or environmentalism in toto, can illustrate Swedish responsiveness to the 'population' and the general 'tactics of governmentality'.

From the late twentieth century, however, three main interlinked factors have changed. First, the increase of immigrants (read: Muslims) have transformed the cultural setting in Sweden. Despite the perception of homogeneity, Sweden has in fact not been homogenous in the sense that there have always existed cultural differences in terms of north/south, west/east, rural/urban, high-educated/low-educated, etc. However, the new cultural constellation, with persons with different appearances (clothing as well as skin complexion and hair colors) and with different views on 'Swedish' values, has created a notion of heterogeneity and parallel value systems, a contrast to the notion of 'the Swedish homogeneity'.

Second, the opening up for the establishment of private schools funded by the governments has made it possible, at least in praxis if not in theory, to socialize children into a different value system than the 'Swedish'. The norms that children in these schools internalize might not be within the boundaries tolerated by society or the state, and the principle of 'governmentality', the aspect of citizens' self-governess or self-discipline according to tolerated norms, loosens up while the discourse of the majority and its control over citizens' minds to a great extent weakens.

Third, since the late twentieth century, governmental control of public space through media, particularly national radio and television, has weakened drastically with the advent of cable and satellite dishes. The fragmentation of public space has various implications. As it comes to the youth, whether majority or minority, they watch American sit-coms and reality shows more than Swedish 'educational' programs. Thus, the internalizing of 'Swedish values', even for the majority

6 The Swedish state's TV-monopoly ended, when the first commercial Scandinavian TV-channel, TV 3, was launched December 31, 1987. To avoid Scandinavian legislation's prohibition of commercial TV-channels TV3 sent to the three Scandinavian countries via satellite from the head office in London [24].

7 Foucault links self-government to morality ([25], p. 91). Although his discussion of self-government is linked to the state power it is also reasonable to see self-government in terms of how through the art of governing, individuals will be socialized into a moral self-governing system. 
youth population, is at stake. Moreover, the immigrant population tends to watch the national satellite television programs of their countries of origin, or for the Arabic-speaking population in Sweden, the various Arab-medium news channels portraying international events in a fashion quite differently from Swedish news program [2].

As a result, the Swedish value systems have loosened in recent decades, and the system of 'governmentality' as a means of controlling the population's attitudes, norms, and practices has become more complicated than it used to be. The episode of a young Muslim woman, born in Egypt and raised in Sweden from the age of four, who served as a kindergarten teacher and who claimed her right to wear a face-veil at work, illustrates the gap between legislation and norms which have arisen in this newly fragmented public space. As politicians and public employees wanted to ban the use of face-veil, the woman complained to the Swedish Ombudsman that she was a victim of ethnic discrimination. The claim for change in the legislation of what is 'acceptable' clothing and what is not was put forward in the following debate. The debate indicates how norms for acceptability have previously been well internalized; there has been a common public recognition of what is approved or disapproved of in the public sphere, making for instance legislation on clothing unnecessary. But in Foucault's words: "A power whose task is to take charge of life needs continuous regulatory and corrective mechanisms" ([28], p. 144). The general tactics of 'governmentality' is therefore also about broadening, narrowing, and moving the borderlines according to socio-political and cultural public discourses. With the fragmentation of the public sphere, public norms become less homogenous and less obvious, but, despite the weakening of governmental control of its subordinates, it is still mainly the authorities who can decide or place limits on what is 'acceptable' and 'unacceptable' through bio-politics, legislation, media, and policy-making.

\section{Majority-Minority Dynamics in Sweden}

It is obvious that there are conflicting issues between the majority in Sweden and the Muslim minorities. One important issue is the Swedish involvement in Afghanistan, as well as the authorities' lack of public criticism of Israeli policy on the occupied Palestinian territories. Although important, these issues fall outside the scope of this study. This study's purpose is to examine Swedish internal affairs as it pertains to the majority-minority relations.

The concept of 'governmentality' is a convenient analytical tool for examining the relationship between the majority population and minority communities in a country like Sweden with its underlying claim of homogeneity.

\section{Muslims in Media}

In order to evaluate how the media can influence the relationship between the majority and Muslim minority communities in Sweden, it will be fruitful to compare the Swedish approach to that of Denmark and Norway. To a certain degree, both the media and the Danish authorities, with the latter's embracing of the populist party, The Danish People's Party (Det Danske Folkepartiet), along with that party's hostile discourse towards Muslims and Islam, tend to have a quite hostile attitudes towards immigrants, which in the Danish context has become synonymous with 
Muslims [29]. In Sweden, on the other hand, there is a general wariness and caution in the portrayal of immigrants in general. In between the two extremities lies Norway, where public discourse tends to oscillate between the two positions, as will be indicated below.

When it comes to the images of Muslim immigrants in public discourse, the difference between Sweden on the one side and Denmark and Norway on the other can be illustrated by the media discussion of Islam and honor killings after the Kurdish-Swedish woman, Fadime Sahindal, was killed by her father in January 2002. In Sweden, Islam was mentioned as a possible accomplice to the killing in the days that immediately followed. After a relative of the family told the national television that the family has no Muslim background (which it indeed had, although the father had no religious inclination) ([30], p. 29), the public debate shifted its focus to Kurdishness rather than Islam, with the understanding that the killing was a result of women being victimized by men in general. In the two other countries, honor killings and Islam remained as the primary explanations in public debate for the killing of Fadime, with the prohibition in Islamic law against marriage between Muslim women and non-Muslim men viewed as the cause of her death ([30], pp. 29-30). (Interestingly, the man Fadime had a relationship with was also probably from a Muslim background, as his father was a refugee from Iran.)

Another important aspect is how the media handles the naming and describing of criminals. In October 2012, the text-television of the national TV-company DR1 broadcast breaking news on three wanted criminals. All three criminals were identified by name, and two of them had obvious Muslim names. In a large Danish newspaper BT in November 2011, the names of both the murdered person and the suspected murderer were released, and both names were Muslim. In contrast, in Sweden, names are only released in the media after the person(s) has been tried and found guilty by a court. Even the victim is seldom identified by name since this is regarded to lead to speculation as to whether she/he has a non-Swedish name. This is clearly an attempt to reduce anti-immigrant sentiments. In two immigrant-dense towns in Scania, in southern Sweden, three women were murdered by close relatives with immigrant backgrounds in the period between April and July 2012. ${ }^{8}$ In all three cases, names and additional information that could link the victim or the killer to immigrant milieus were not released.

Even when a program on Islamist organizations and their close cooperation with government officials in Sweden was broadcast on national television in December 2009, there were no follow-up television reports, and there were few reactions in the Swedish press. Both in Denmark and in Norway, such programs tend to set off a chain reaction in the press, with news programs on most television stations as well as daily newspapers conducting follow-up reports in which experts and Muslims of various stands are interviewed.

The caution showed by the Swedish media, and the informal directive of withholding names and information that might stigmatize immigrants in general and Muslims in particular, might be regarded in view of 'governmentality'. As stated above, in Sweden, there has been a tendency to embrace parts of conflicting ideologies or ideas, such as 'feminism' and 'environmentalism', in order to keep the social homogeneity and avoid open conflicts. Thus, by embracing and promoting

8 The information of the killers' 'immigrant background' was given to me by two journalists working in the national TV company SVT. 
immigrants as part of the 'Swedish', it is possible for the authorities to accept and promote cultural and social traits found among immigrant communities that are within the limits of the 'acceptable', limits which are continuously regulated according to legislation and the majority discourse. When relating extremist issues, politicians, journalists, and experts on Islam tend to use the recurrent narrative that although some Muslims are terrorists, have extremist views, or belong to criminal gangs, this does not extend to all Muslims in Sweden [31].

The aim of promoting self-governess or self-discipline has been largely successful, at least as it comes to many leading Muslims in Sweden. The general awareness of how immigrants are portrayed in the media and how the political parties tend to protect immigrant rights might be a reason why many Muslims leaders express loyalty to the 'Swedish system'. ${ }^{9}$ Moreover, the emphasis by most political parties on engaging Muslims reinforces this sense of loyalty towards the Swedish authorities and society. In a study of Muslims in positions of leadership in various political parties, all expressed that they felt their views were accepted and listened to by their party fellows ([3], p. 161). One prominent Muslim politician from a party that actively supports homosexuals' rights in all fields of human life, including the adoption of children, expressed his support for such rights even though he is a practicing Muslim. "If we, the Muslims request equal rights, then we also have to accept that this request also goes for other discriminated communities in society, such as for instance the homosexuals." $" 10$ Other practicing Muslims from various parties expressed that they did not support homosexuals' rights, but as members of parties who did, they chose to just withdraw during such discussions and refrain from taking an official stand. This is an example of 'governmentality'; Muslim immigrants have internalized the notion of homogenization and abstain from explicitly express their divergent view on homosexuals, a view which is not within 'the acceptable' in Swedish society.

\section{Populist Parties}

All three Scandinavian countries have populist parties with parliamentary representation. But whereas in Norway and Denmark these parties not only wield significant influence, directly and indirectly, but also cooperate with other parties in Parliament, in Sweden, the newly established Sweden Democrats are more or less boycotted by the other parliamentary parties. In this case, the Swedish authorities have not employed their strategy of embracing conflicting ideologies. An ethnic Swedish political activist from the centre-right ruling party, the Moderate Party (Moderaterna) explained to me: "The Sweden Democrats are racists, and we do not cooperate with people who distinguish between races and religions". In view of the concept of 'governmentality', Swedish authorities have not included 'hostility towards immigrants' into what is socially acceptable. In Denmark, the strength of the Danish People's Party (Dansk Folkeparti) after the election in 2001 made other parties respond positively to their propositions in Parliament. Interestingly, Norway's Conservative Party (Høyre), which is in a position to win the election in 2013, has pushed the boundaries of what is acceptable and what is not by opening up for a possible

\footnotetext{
9 Interviews with Muslim leaders from various Islamic associations, 1996-2012.

10 This informant is in his late thirties and came to Sweden from a southern European country as a toddler. He has an explicit Islamic identity.
} 
cooperation with the Progress Party (Fremskrittspartiet), a populist party. ${ }^{11}$ This is in contrast to the Conservative Party's firm opposition to the Progress Party in 2001, when the former's party management insisted that such cooperation would be a "nightmare scenario" [33]. The reason behind the differences between Sweden and the two other countries might, apart from that the populist parties in Denmark and Norway have a longer experience in politics, be as simple as pure pragmatism. The percentage of the immigrant population in Sweden is much higher than in Denmark and Norway [34]. Moreover, in all the three Scandinavian countries, coalition governments have become the rule rather than the exception, and the major political parties might be in need of the populist parties in order to form a government. In Sweden, the Sweden Democrats is still a small party with less than 10 per cent of the voters. In October 2012, the Sweden Democrat announced a zero tolerance for racist expressions within the party [35]. Only time will tell whether this new approach, together with the potential growth of the Sweden Democrats, will make the party more housebroken from the public viewpoint.

It is interesting to note that the Liberal Party (Folkpartiet), a party with governmental representation, launched a proposition with more demands on immigrants, demands that overlap with those of the Sweden Democrats. These include demands for immigrants to possess a certain amount of Swedish language proficiency when applying for citizenship, for unemployment insurance to be withdrawn if immigrants reject a job offer, and that social service or state-sponsored economic support for immigrants should depend upon their participation in specific activities. These demands generated massive criticism from other political parties as well as in media [36].

Furthermore, 'banal nationalism' is strong in both Norway and Denmark where there is emphasis for example on flags as well as 'Norwegianness' and 'Danishness'. In Sweden, such nationalist manifestations are less frequent. A common notion is that this lack of 'banal nationalism' is linked to the fact that Sweden has not had war on its soil for approximately 200 years, a marked contrast to Denmark and Norway in light of the German occupations of the Second World War. This lack of expressed national sentiments might explain the fact that the Swedish populist parties have been less successful than their counterparts in Denmark and Norway. Since the local government election of 2008, however, the Sweden Democrats have started to become more visible in the public sphere, and in the parliamentary elections in 2010, the party gained parliamentary seats. The party has its strongest support in Scania, a region with many Muslim immigrants.

The public debate has to a certain extent changed as the Sweden Democrats have increased their influence in the public space. However, when the head of the party announced in the newspaper Aftonbladet that "Muslims are our greatest foreign threat" [37], he was attacked by most political representatives as well as the broader public. He was even sued for "frenzy against an ethnic group", a criminal offence in Sweden. In contrast, in Denmark and even in Norway, politicians and the media can be much more outspoken in their criticism towards Muslims without fearing legal proceedings ([38], pp. 69-77). Many Muslim politicians in Denmark have been questioned for their "Islamic values", and some of them have been forced to leave the political scene due to heavy media campaigns against them [39]. Muslim politicians in Sweden have not been questioned in this way.

11 According to the Official Poll January 16th, 2013, The Conservative Party got 32.2\% and the Progressive Party $16.8 \%$ of the votes [32]. 
The 'governmental rationality' of the Swedish rightist government (2012) is to include the immigrants, regarding them as a beneficial source for social development in Sweden. The populists, however, are outside what is regarded as acceptable, at least for the time being. The government's policy towards the Sweden Democrats reinforces the accommodating attitude towards immigrants, particularly Muslims, as some leading politicians within the Sweden Democrats have an expressed anti-Islamic or Eurabian sentiments [40].

\section{Developments in Swedish Muslim Communities}

Researchers have anticipated an individualization process among Muslim youth in Scandinavia [3,41]. One study of Pakistani children and youth in Norway indicated that the younger generations of Muslims developed integrated plural identities and became both 'Norwegian' and 'Pakistani'. Muslim youth tend to embrace individualistic 'Norwegian' values such as freedom, democracy, gender equality, etc., yet they also embrace more collective values identified with their parents' worldview, such as belonging to a group, a religion, etc. [41]. There are similar findings in Sweden on issues such as gender relation and the relationship between individual and collective rights ([3], pp. 165, 201-03).

The gender equality policy in Scandinavia has influenced Muslim communities. Many practicing Muslims from second- and third-generation immigrant communities claim that "Islam is gender equality" ([3], p. 20). In contrast to their children, most of the first-generation practicing Muslims believed that "[i]n Islam we do not have gender equality" ([3], p. 20). This generational difference reflects the variation in socialization and public discourse. First-generation Muslims link Islam to the gender values they were socialized into in their homelands. One example of this might entail the belief that demonstrating respect for women means that male relatives must provide women with protection and economic support. However, those Swedish Muslims who have attended Swedish schools have internalized a different value, the value of gender equality. This is understandable given that gender equality saturates the entire educational system in Sweden.

This difference in understanding can be linked to Bobby Said's perception of 'Islam' as the master signifier, i.e., Islam becomes a reference point with different content in varying contexts [42]. 'Islam' becomes 'the incarnated good', and despite the variation in content, this master signifier maintains the interpretive framework as Muslims believe in 'Islam' and create its content in varying contexts. Thus, Islam becomes that which is 'good' in each and every context. In many of the countries of origin of Swedish Muslim immigrants, including Afghanistan and the Arab countries, public discourse has set the standard of what is 'good' for women, namely to be protected, whereas in Sweden the 'good' is equal gender opportunities. For Muslims born in Sweden, what is 'good' goes even for other Swedish values such as individual rights, democracy, tolerance, etc. A practicing Swedish Muslim woman with Lebanese-Palestinian parents talked about the importance for women to take individual responsibility for their Islamic practice. "If you wear a hijab because your parents or your husband force it upon you, you will have no divine reward (ajar). To wear a hijab is an individual choice". ${ }^{12}$ Her mother, however, expressed a different view: "I want my daughter to wear hijab because that make her a decent woman, and God

12 Interview with 'Huda' 27 years, July 2002 in Sweden. 
wants women to be decent dressed and not to be temptresses, creating chaos (fawda) in society."13 The mother's view indicates a collectivistic view of Islam as a social system, regarding social order as well as family values and family coherence as important Islamic values.

The governmental policy of equal gender opportunities is also reinforced in the material world. The same Swedish system that creates the need for both men and women to enter the labor market also affects Muslim communities. Many Muslim immigrants in Sweden have lower educational levels in comparison to the majority population. Many also have difficulties learning the Swedish language, an important prerequisite for getting a job. Therefore, many Muslims are dependent on economic support from the state, which means that even refugee and immigrant women must actively seek employment. Sweden has social programs with courses and training for women that help them acquire a stronger position in the labor market. This has created a change in gender structures in Muslim communities toward a much more egalitarian system of labor division, a contrast from the countries of origin where women mainly work in the domestic sphere. ${ }^{14}$

Another example that reflects Muslim adaption to Swedish homogeneity is the view on sharia among Muslim leaders in Sweden. Prior to the parliamentary elections of 2006, the leader of the Swedish Muslim Association (Sveriges Muslimska Förbund), Mahmoud Aldebe, wrote an official letter to the political parties. The letter was published in the newspaper Dagens Nyheter on April 27, 2006. In the letter, Aldebe asked for legislation giving Muslims the right to take leave on religious festivals, to have a mosque in every city, to have particular days for men and women in the local swimming pools, and to have sectoral legislation in family legislation issues [43]. Aldebe argued that the law on freedom of religion in Sweden is built on an 'individualized understanding of religion' whereas Muslims focus on 'the collective expressions of religion' [43]. On the following day, Aldebe modified the content of the letter in a press release in the same newspaper. He withdrew the claim for 'sectoral legislation' for Muslims, asking instead for the possibility of dispensation in certain cases [44]. It is interesting that the strongest criticisms of Aldebe's claim on sectoral legislation came from within the ranks of Sweden's Muslim leadership. The spokesperson of one of the largest Muslim national organizations, Mehmet Kaplan, rejected Aldebe's claim: "He [Aldebe] cannot be a spokesman for all Muslims. This is the role he put on himself when he wrote 'Muslims believe' and 'Muslims demand"' [44]. Kaplan agreed with some of Aldebe's claims, such as the right to take leave on religious festivals. Still, Kaplan insisted that the request for sectoral legislation was totally unreasonable. Even leaders within Aldebe's own organization rejected his claim publicly [44].

Aldebe, who has a Palestinian-Jordanian background, is a first-generation Muslim immigrant who came to Sweden as an adult. Kaplan is of Turkish origin and came to Sweden at the age of one. Through his Scandinavian upbringing and education in Swedish school, Kaplan is well socialized into the system of self-governess. He is fully aware of what is and is not 'acceptable' in public space. It is likely he would agree with the majority discourse. Therefore, the issues he agrees with in Aldebe's letter are all acceptable claims according to 'governmental rationality', whereas

\footnotetext{
13 Interview with 'Huda's' mother, July 2002. She was 59 years at the time of the interview in July 2002, and she came to Sweden in 1989, 46 years old.

14 Personal observation in Arab-speaking communities in Sweden and Norway.
} 
the claim for sectoral legislation, particularly in regards to the gender issues that Aldebe focused on, are far beyond what is acceptable. Kaplan is an example of what Foucault sees as a citizen's internalized self-governess or self-discipline.

\section{0. 'Governmentality' and Socialization}

In Sweden, Muslim communities tend to be regarded as 'problematic'. This is due largely to social problems that are linked to class, low educational levels, and a lack of social networking within majority society, as opposed to religion or Islam. However, in Muslim minority communities as well as in the majority population, one encounters individuals from a wide array of class, educational, and employment backgrounds and levels. With the social mobility of some second- and third-generation Muslim immigrants and the change of Islamic discourses from patriarchal to equal rights, the stereotyped image of Muslims as 'deprived victims' (read: Muslim women) or as 'oppressive patriarchs' (read: Muslim men) may gradually change. The constellation of Muslim communities in Sweden, together with particular features of Swedish state policy, influences the situation in Sweden. As Muslim youth are socialized into Swedish realities, they might gradually internalize Swedish identities and loyalties. As discussed above, the wariness in the media that affects how Muslims and Islam are covered, as well as the official policy towards the populist Sweden Democrats, has already created fertile soil for Muslims, including those of the first generation, to feel loyal to the Swedish authorities.

More important is that the newer generations of Muslims will ask different questions than their parents, and they will get different Islamic answers to some of the same questions asked by their parents, as indicated above in the discussion of Islam $v s$. equal gender opportunities. The strong emphasis on equality, particularly in regards to gender, might impact the Islamic discourse on gender as well as on tolerance towards religious and social diversity. Muslim youth's activism in Sweden promises new tendencies in Muslim understandings of the Islamic sources. However, whether new generations of Muslims will experience a true 'sense of belonging' [45] to Swedish society depends not only on changes within Muslim communities. It depends also, to a great extent, on the art of government, i.e., the aspect of 'governmentality', and on how well the majority population manages to incorporate parts of nonconformist thinking and to enlarge the boundaries of what is acceptable. Moreover, the particular art of 'governmentality' in Sweden might be a reason for the relative avoidance of conflicts, in the Huntington sense of civilizational clashes, between the majority and the Muslim minorities. Many Muslims, particularly those born and raised in Sweden, are socialized into the art of self-governance, according to that which is socially acceptable or unacceptable, making their attitudes and behavior, to a lesser or greater extent, well-tuned into the majority way of life.

Although this study focuses particularly on Sweden, Danish and Norwegian material has also been included. A study I conducted in Norway in 2004 shows a similar trend of loyalty and changes towards more individualistic attitudes and behavior among the descendants of the first generation of Muslim immigrants [3]. This is true even though the Norwegian media has a much more critical attitude towards Muslim communities than the Swedish media. This might indicate that although the dynamics between the majority population and Muslim minority communities is important, the system of 'governmentality' is also an influential factor when it comes to the 
internalization of 'Norwegian' or 'Swedish' values. As Muslim youth attend public schools together with the non-Muslim majority, the values and behavior promoted in the majority discourse will probably play a role in their socialization process and in the process of construction of their identity.

\section{References}

1. Roald, Anne Sofie. "Mecca of Gender Equality: Muslim Women in Sweden." In Muslim Women in the United Kingdom and Beyond. Edited by H. Jawad, T. Benn. Leiden and Boston: Brill, 2003, 65-89.

2. Roald, Anne Sofie. "Arab Satellite Broadcasting - the immigrants' extended ear to their homelands." In Muslims in Europe. From the Margin to the Centre. Edited by J. Malik. Munster: LIT, 2004, 207-26.

3. Roald, Anne Sofie. Muslimer i Nya Samhällen. Göteborg: Daidalos, 2009.

4. Roald, Anne Sofie. "Multiculturalism, religious marriages and secular divorces." In Muslim Diaspora in the West. Negotiating Gender, Home and Belonging. Edited by H. Moghissi, H. Ghorashi. Surrey and Burlington: Ashgate, 2010, 55-72.

5. Runblom, Harald, and Hans Norman. From Sweden to America: A History of the Migration. Minneapolis: University of Minnesota Press, 1976.

6. Karlsson, Pia, and Ingvar Svanberg. Moskeer $i$ Sverige En Religionsetnologisk studie $i$ intolerans och administrativ vanmakt. Serien Tro och Tanke 7/95. Uppsala: Svenska Kyrkans Forskningsråd, 1995.

7. Román, Henrik. En invandrarpolitisk oppositionell. Debattören David Schwarz syn på svensk invandrarpolitik åren 1964-1993. Uppsala: Centre for MultiethnicResearch, 1994. Uppsala Multiethnic Papers No. 31.

8. SOU (Swedish Government's Official Reports). Investigation of Immigrants 3. Stockholm: Regeringskansliet, 1974.

9. Larsson, Göran. "Sweden." In Islam in the Nordic and Baltic Countries. Edited by G. Larsson. London: Routledge, 2009, 56-75.

10. SST (Nämnden för statligt stöd till trossamfund [the Swedish Commission for Government Support to Faith Communities]. "Statistics for members registered in faith communities in Sweden in 2011." Available online: http:/www.sst.a.se/statistik/ statistik2011.4.4bf439da1355ecafdd2243b.html (accessed on 28 January 2013).

11. Österberg, Eva. Mentalities and Other Realities. Essays in Medieval and Early Modern Scandinavian History. Lund: Lund University Press, 1991.

12. Rojas, Mauricio. The Rise and Fall of the Swedish Model. London: The Social Market Foundation, 1998.

13. Berggren, Henrik, and Lars Trägårdh. Är Svenskan Människa? Gemenskap och beroende i det moderna Sverige. Stockholm: Nordstedts, 2006.

14. Gullestad, Marianne. Det norske sett med nye øyne. Kritisk analyse av norsk innvandringsdebatt. Oslo: Universitetsforlaget, 2002.

15. Sander, Åke. "The Status of Muslim Communities in Sweden." In Muslim Communities in the New Europe. Edited by G. Nonneman, T. Niblock, B. Szajkowski. London: Ithaca, 1996, 269-91. 
16. Ehn, Billy, and Orvar Löfgren. Kulturanalys:Ett etnologiskt perspektiv. Lund: Liber Förlag, 1982.

17. Gelb, Joyce. Feminism and Politics: A Comparative Study. Berkeley: University of California Press, 1989.

18. "Stefan Löfven är feminist." Dagens Nyheter, 27 January 2012. http://www.dn.se/nyheter/politik/stefan-lofven-ar-feminist.

19. Jamison, Andrew, Ron Eyerman, Jacqueline Cramer, and Jeppe Laesser. The Making of the New Environmental Consciousness. Edinburg: Edinburg University Press, 1990.

20. Soysal, Yasemin. Limits of Citizenship. Migrants and Postnational Membership in Europe. Chicago: The University of Chicago Press, 1994.

21. Grant Thornton Report. "European Business Survey 2002." Available online: http://www.internationalbusinessreport.com/files/ebs_2002_report.pdf (accessed on 20 October 2012).

22. Florin, Christina, Bengt Nilsson. "Something in the nature of a bloodless revolution: Gender equality policy in Sweden in the 1960s and 70s." In State Policy and Gender System in the two German States and Sweden. Edited by R. Torstendahl. Uppsala: Opuscula Historica Upsaliensia, 1999, 11-77.

23. Lindencrona, Gustaf. "Från sam- till särbeskattning. En studie i skatterätt och jämställdhet." SkatteNytt 5 (1989): 193-209.

24. Modern Times Group. "TV3 Sverige.” Available online: http://www.mtg.se/sv/varumarken-verksamhet/varumarken/fri-tv/tv3-sverige/ (accessed on 29 January 2013).

25. Foucault, Michel. "Governmentality." In The Foucault Effect. Studies in Governmentality. With Two Lectures by and an Interview with Michel Foucault. Edited by G. Burchell, C. Gordon, P. Miller. Chicago: The University of Chicago Press, 1991, 87-104.

26. Foucault, Michel. "Omnes et sigulatim: Towards a critique of 'Political Reason'." Lectures delivered at Stanford University October 10 and 16, 1979. http://tannerlectures.utah.edu/ lectures/documents/foucault81.pdf.

27. Gordon, Colin. "Governmental rationality: an introduction." In The Foucault Effect. Studies in Governmentality. With Two Lectures by and an Interview with Michel Foucault. Edited by G. Burchell, C. Gordon, P. Miller. Chicago: The University of Chicago Press, 1991.

28. Foucault, Michel. The Will to Knowledge (The History of Sexuality I). London: Penguin Books, 1998 (1976).

29. Hussain, Mustafa. "Islam, media and minorities in Denmark." Current Sociology 484 (2000): 95-116.

30. Wikan, Unni. En Fråga om Heder. Stockholm: Ordfront, 2004. [In Honour of Fadime. Chicago: The University of Chicago Press, 2008.]

31. Lönnaeus, Olle. "Slutmålet: ett globalt shariastyre." Sydsvenskan, 15 October 2012, A 12-13.

32. "Helblått flertall på valgårets første Gallup for TV2." Available online: http://www.tnsgallup.no/?aid=9075372\&archive=true \&nid=9105256 (accessed on 28 January 2013).

33. Bisgaard, Anders. B. "Blå himmel igjen." Morgenbladet, 7-13 September 2012, 6-7.

34. Norden. "Befolkning." Available online: http://www.norden.org/sv/fakta-om-norden/befolkning (accessed on 17 October 2012). 
35. Schreiber, Johanna. "Jimmy Åkesson: Blir nolltolerans mot rasism.” Expressen, 12 October 2012. http://www.expressen.se/nyheter/jimmie-akesson-blir-nolltolerans-mot-rasism.

36. Marmorstein, Elisabeth. "FP vill bli tuffare mot invandare - igen." Aftonbladet, 12 June 2012. http://www.aftonbladet.se/nyheter/article14964597.ab.

37. "Muslimer är vårt största utländska hot." Aftonbladet, 19 October 2009.

38. Roald, Anne Sofie. New Muslims in the European Context. The Experience of Scandinavian Converts. Leiden: Brill, 2004.

39. Schmidt, Garbi. "Islam in Denmark." In Islam in the Nordic and Baltic Countries. Edited by G. Larsson. London: Routledge, 2009, 40-55.

40. Ekeroth, Kent. Homepage: http://kentekeroth.se/.

41. Østberg, Sissel. "Islamic Nurture and Identity Management." British Journal of Religious Education 1 (2000): 91-103.

42. Sayyid, Bobby. A Fundamental Fear. Eurocentrism and the emergence of Islamism; London and New York: Zed Books LTD, 1997.

43. Kihlström, Staffan. "Muslimskt Förbund kräver egna lagar." Dagens Nyheter, 27 April 2006. http://www.dn.se/nyheter/sverige/muslimskt-forbund-kraver-egna-lagar.

44. "Muslimskt krismöte efter krav på särlagstiftning." Dagens Nyheter, 28 April 2006.

45. Ramadan, Tariq. "To be a European Muslim. Commonalities and diversity." Lecture given at the Norwegian Academy of Science, Oslo, Norway, 1 and 2 November 2007. 


\title{
Religious Racism: Islamophobia and Antisemitism in Italian Society
}

\author{
Alfredo Alietti and Dario Padovan
}

\begin{abstract}
Racism and racial prejudice, considered a relic of obsolete and outdated social systems, is emerging in the depths of ultra-modern Western societies with different characteristics from the past but with a surprising and worrying virulence. These waves of prejudice and racism testify to the many fears that fill the horizons of advanced societies, undermining not only their internal reliability, but also just their democratic settings. This paper presents a critical review of Islamophobia as a racial prejudice, showing that two main definitions are at work: Islamophobia as xeno-racism or linked to the so-called clash of civilizations. Then, it presents the outcomes coming from a Computer Assisted Telephone Interview (CATI) survey led among a representative sample of the Italian population $(n=1,523)$ on Antisemitic and Islamophobic attitudes. The cogency and structure of anti-Muslim public discourse and connected mass attitudes, revealed by our investigation, confirm the emergency of these two relevant dimensions of Islamophobia, which claim for a more accurate definition of Islamophobia. Moreover, the distribution of anti-Semitic and Islamophobic attitudes illustrate an interesting overlapping of Islamophobia and Antisemitism which claims that racism is multi-targeted and that there is not so much options between Antisemitism and Islamophobia. Finally, we use three main variables-anomie, ethnocentrism, and authoritarianism-as predictors of Islamophobia and Antisemitism. We tested the strength of these three predictors with the aid of path technique based on multiple regression analysis, which helps to determine the direct and indirect impacts of certain independent variables on dependent variables in a hypothetical causal system.
\end{abstract}

Reprinted from Religions. Cite as: Alietti, A.; Padovan, D. "Religious Racism. Islamophobia and Antisemitism in Italian Society." Religions 4 (2013): 584-602.

\section{Introduction}

Despite what is claimed by fans of neoliberal globalization, societies have not moved to a state of deep and widespread prosperity, free from conflict, hostility, exclusion, and discrimination. Racism and racial prejudice, considered a relic of obsolete and outdated social systems, is emerging in the depths of ultra-modern Western societies with different characteristics from the past but with a surprising and worrying virulence. They testify to the many fears that fill the horizons of advanced societies, undermining not only the internal reliability, but also just their 
democratic settings. Forms of racial prejudice, such as Antisemitism, reappear in unexpected forms, presenting new and unpredicted characteristics, whereas Islamophobia seems to challenge, by diffusion, transversality, and essentiality, the worst historical anti-Semitic exhibitions of early twentieth century. These waves of racial prejudice that are passing through all Western countries seem to tackle more with cultural and religious signs of otherness than with differences inscribed upon bodily traits. This is the reason why some scholar speaks of "religious-driven hatred and hostility" [1].

The endeavour of this research is to understand the nature of these new cultural and religious racisms, which are irresistibly growing up inside Western societies. In the paper we will use different terms and concepts — such as prejudice, racism, hostility, intolerance, discrimination, and so on-to which we give, for now, similar and interchangeable meaning. We realize that the logics of racism are not easy understandable, but the reasoned choice of appropriate theoretical vocabulary for the definition of plastic, changing, elusive phenomena such as Islamophobia or Antisemitism, on which scholars are still questioning, may be a consequence and not a premise of researches such as that presented here.

This research is based on 1528 interviewed with CATI technique (Computer Assisted Telephone Interview) subjects, which are a representative sample of the Italian population stratified according to age, gender, and residence. The questionnaire used was built by a set of scales divided according to areas covered by our working hypothesis, scales that are part of a well-established empirical tradition. Regarding the items of the scales of Antisemitism and Islamophobia, we have pursued well-beaten paths, especially those related to questions (items) on anti-Semitic attitudes that have reached in time a certain maturity and methodological validation, whereas for the anti-Muslim attitudes the situation is less clear and evolved [2]. To these scales we add three others scales pursuing a strategy aimed at the unveiling of a structured model, which takes into account some crucial attitudes of the psycho-sociological dynamics of prejudice. Specifically, we designed three scales aimed at the identification of these attitudes, respectively the authoritarianism, ethnocentrism, and anomie scales.

The frame for the reflection upon data is formed by different sections: in the second we discuss some aspects of the Islamophobia category, trying to identify among scholars two different and latent dimensions of Islamophobia, the first related to the so called xeno-racism the second to idea of clash of civilizations. In the third one, we present some anti-Muslim discourses spread in Italy in recent years. In the fourth section we discuss on the basis of our data the two dimensions of Islamophobia while in the fifth we present some theoretical aspects related to the empirical overlapping of Antisemitism and Islamophobia. Finally, we present the racist predictors pattern we used to explain the nature of this new racism, its liquidity and its final and unexpected function of social bonding.

\section{Some Critical Notes on Islamophobia}

In recent literature, the prejudice against Muslims has been called Islamophobia, the meaning of which was delineated in 1997 by the Commission on British Muslims and Islamophobia promoted by Runnymede Trust [3]. The use of that category, and its variations, has not been without criticism and disagreement, more or less legitimate and plausible [4]. This has led us to a short reflection on 
the general concept of Islamophobia. First of all, a "phobia" is not racism. It is an attitude that is fed more by fears than a willingness to subordinate, racialize, and crystallize the differences and inequalities of the "Other", as in the case of Antisemitism. Even though it encourages racist attitudes or practices and it is able to change from fear to racism, it is not by definition a racial prejudice. Islamophobia appears in such way as a polysemic concept, embracing too much different phenomena and with porous borders permeable to various kinds of interpretation. The Runnymede Trust's large definition of Islamophobia risks losing a rigorous perspective of analysis $[1,5]$. Therefore, the term Islamophobia is to some extent misleading, as it refers primarily to a fear of Islam historically rooted in the Christian-Western culture since the time of the Crusades. As reported by Zafar Iqbal, "Islamophobia is a new word for an old fear". It is a form of religious intolerance, whose manifestations can be found in historic wars, crusades and genocides spread long over centuries [6].

In reality, these deep feelings of cultural distance often overlap to broader phenomena as, for example, fear of immigrants or foreigners. Moreover, Islamophobia refers to a perception of threat that seems not thus widespread as the belief that the Muslims are instead a closed and biased group. As suggested by Heitmeyer and Zick [7], Islamophobia is a form of group-oriented enmity and a general attitude of rejection of Muslims and all religious symbols and rituals that stem from the Islam. This definition focuses on construction of the enemy, which implies not only a generic 'phobia', but a rational construction of a racialized other where symbols and rituals become parts of an unchangeable identity. Here 'phobia' becomes a racism, because it transforms the bearer of a perceived threat in a racialized 'Other', where there is a strong continuity between religious characters and individual behavior, in which it is thought that the group exercises strong influence on individual will, where differences are crystallized once for all.

Without wishing to belittle or invalidate the concept of Islamophobia as a means to highlight aggressive and hostile attitudes and discourses against Muslims, we think that it is possible to recognize two different patterns of Islamophobia or anti-Muslim racism: one oriented to the model of 'internal enemy' and strictly connected with the fear of the proximity of Muslim body [1]; the second oriented to a more general view of Islamic civilization as an 'external threat' perpetrating attacks, wars and invasions. In the first case we observe an Islamophobia that seems very close to the so-called cultural or differential racism [8,9]. The lack of phenotypic racial characters of people targeted by this cultural racism makes it moving towards a religious-driven racism very close to Antisemitism. As suggested by Balibar [9], all the contemporary differential racism can be understood from the formal point of view as generalized Antisemitism. For this reason it is possible to understand the potential theoretical proximity of the terrorist, fanatic, violent, and intolerant Muslim with the dreadful, conspirator, outrageous Jew. Although different and not fully overlapped, racisms fed by these figures share the same classical racial morphology and the same authoritarian and fascist syndrome well known in European history [10].

The difference is that in recent years the new Islamophobia has replaced in the prejudiced social imaginary, as regards distribution, grounding and virulence, the old Antisemitism, to the point where it should be compared to hostility against the Roma, perhaps the most stigmatized and racialized subject around the world. The folk devil represented by the Muslim - and in smaller measure the Jew-is, in this view, a figure of collective anxieties and fears, a scapegoat which 
nourishes the racist and fascist conviction that only cultural, religious and racial purity can stem the breakdown of social order and the collapse of society [11]. This kind of anti-Muslim prejudice is a process in which Muslims - but also Roma, Blacks, Jews, Asians - are seen as a threat to the purity and order of the nation and its ethnic fabric, a nation imagined as a cohesive community. In this way, the racism we are facing is liquid, transitive, highly mobile, generically oriented against all foreigners. Following the Sivanandan definition, we are witnessing the rising of a new racism, called 'xenoracism' [12]. This anti-foreignness sentiment, this fear of strangers means at the same time the defence and preservation of "our people", our way of life, our standard of living, and our "race". "If it is xenophobia, it is - in the way it denigrates people before segregating or expelling them - a xenophobia that bears all the marks of the old racism, except that it is not color-coded. It is xeno-racism: a feature of the Manichaean world of global capitalism, where there are only the rich and the poor-and poverty is the new black. The rhetoric of demonisation is racist, but the politics of exclusion is economic: a prelude to creating a peripatetic underclass of international Untermenschen".

After the September 11, this xeno-racism has been directed against Muslim communities even though they have been settled in Europe for decades, and are European born citizens. They do not merely threaten Europe as the "enemy within" in the war on terror; their adherence to Islamic norms and values threatens the notion of Europeanness itself. Under the guise of patriotism, a wholesale anti-Muslim racism has been unleashed which itself threatens to destroy the fabric of the multicultural society [13]. Undoubtedly specular to this process, some Muslims tend to construct a polarized world-view opposing the Islamic ummah and the West, the latter seen to be led by a Jewish-American conspiracy [11].

It is this ubiquity that makes this racism working as a social bond for scared and isolated people inside Western societies, yet not only in these latter. It asks for subordinated assimilation and instantly recognizable inferiorization of Others, putting them on the last rung of an imaginary social ladder. This desire to subordinate the Other is strictly linked with the authoritarianism, which is embracing not only Italian society. Here lies the thrust towards coercive assimilation, through the adoption of a number of measures, which include the recasting of citizenship laws according to security considerations; the introduction of compulsory language and civics tests for citizenship applicants; codes of conduct for the trustees of mosques; a cultural code of conduct for Muslim girls and women who, in some areas of Europe, will be forbidden to wear the hijab in state schools and other state institutions. However, all these obligations are inscribed in the frame of an insurgent authoritarianism and European ethno-nationalism. As has been stressed by different authors, all modern nation-states seek to reduce differences to a majoritarian conceived unity. In this way majorities can feel 'possessive about the country for democratic, historical and other reasons and insist that the definition of national identity should reflect their privileged status. The implication we draw from this concern is that the inclusion of minorities within nation states must necessarily negotiate a potentially coercive "othering" tendency [14] (see also [15]).

The second model of anti-Muslim racism is something new. This kind of racism not only blames the single Muslim or the single domestic settled community, the single fundamentalist who lives next door, the single body which bears intolerable cultural and religious symbols (flags, graves, hijab), but the entire civilization which produced and shaped him. Is this generalization so decisive 
at the point to render Islamophobia a unique and different form of racism quite unlike that of familiar racialization of Roma, Blacks, Jews, or Asians? Are fears leading to Islam-phobia really so different from those driving to Jew-phobia or Roma-phobia? As suggested by Theo Goldberg, 'Islam is taken in the dominant European imaginary to represent a collection of lacks: of freedom; of a disposition of scientific inquiry; of civility and manners; of love of life; of human worth; of equal respect for women and gay people' ([10], p. 345). The guilty party here is the Muslim civilization, which is producing and reproducing anomic and anonymous violent guys, broadly global networked to tear up the social fabric of Western democratic societies. The Islam is bringing death inside Europe, on the fear of which, as pointed out in a very brilliant way by Goldberg, Hobbes so heavily rested the motivation to (Euro-) modernity's social contract. Not individual Muslims, not even Muslim communities, but the collective Muslim, his ancestry civilization and legacy, has come to represent the threat of death. Islam is becoming the monster of our times, our collective nightmare, the paranoia of Europe's cultural demise, of European integrity. In this view Islam appears as the epitome of traditionalism, pre-modernism, the enemy of modernization and globalizing democracy, the bearer of tyranny, despotism, and absolutism. From here, there is the unavoidability of the clash between the West and Islam. In this perspective, as noted by Iqbal, first Orientalism appeared as a fruitful perspective to study Islam and its relations with other civilizations [6]. Then, in the same wake, came Huntington's thesis that a new cold war would take place not on the basis of economics or politics, but based upon culture and civilization marked by epistemic orders and religions.

\section{Public Anti-Muslim Discourse: Some Evidence from Italian Case}

The Italian case presents both these perspectives. Undoubtedly, the Italian case appears in certain ways anomalous if compared to the rest of Western Europe. The specificity of Italian Muslims comes from the great number of their countries of origin, the speed of the settlement, their scarce or sporadic visibility in public space, the fragmentation of their circles, and the weakness of their representativeness in front of public institutions [16,17], in spite of their significant presence being equal to $2 \%$ of the total population.

The reasons for the quick rise of anti-Muslim public speaking considering the early stages of Arab-Islamic immigration are manifold $[17,18]$. The issue of immigration in Italy faces a historic period of profound changes in social, economic, and politics. The early $90 \mathrm{~s}$ witnessed the collapse of the old political system and the emergence of new political forces - such as the Northern League and Forza Italia — whose populist nature has long been analyzed and studied [19-22].

The racist party the Northern League was the key carrier of explicitly anti-immigrant and anti-Muslim positions, promoting both public discourses and national and local governance practices [20]. In his discussion of the Italian variant of populism, Laclau notes that the Northern League has moved increasingly into a 'theory of the enemy' endorsing the idea that if a radical change had to happen the social field had to be split in two [23].

Over time, the Islamophobia of Northern League gained radical forms of mobilization against the construction of mosques in some major cities of the northern regions in which are concentrated the majority of immigrants. According to some observers, the turning point occurred in a small town near Milan, where the granting of land for the construction of buildings to be used as a place 
of worship for the Islamic community unleashed an Islamophobic campaign fiercely reaching extremes, including the invitation to sprinkle the ground with the urine of 'Padanian' pork. The mobilization against the mosques by the Northern League is undoubtedly a paradigm in building the "internal enemy" and to endorse logic of social antagonism. The partial, but significant support of local citizens is the outcome of this emphasis on foreignness.

The legitimacy of an anti-Muslim public discourse aimed at building the internal enemy has found support from some influential intellectuals, opinion-makers and members of the Catholic clergy [24-27]. After September 11, the most widely read and important Italian newspaper, Corriere della Sera, published a long article by the noted novelist Oriana Fallaci, entitled 'The anger and the pride'. The article is an openly racist invective against Muslims (Muslims 'breed like rats', 'we have no place for muezzins, for minarets, for false teetotallers, for their fucking Middle Ages, for their fucking chador'), where she complains against the softness of the West in the confrontation with Islam, which is portrayed as the contemporary absolute evil, a new Nazi-fascism (see [24]).

In 2001, she published a book with the same title of the article [28]. Translated into major languages, it became a sensational bestseller, with more than one million copies sold, reflecting a creeping and a growing consensus in public opinion toward the xenophobic and anti-Muslim arguments developed by Fallaci. Her next book, also published in 2004 and entitled 'The Force of Reason', became a bestseller. Confirming her former extremist thesis, she evokes the risk that the higher birth-rate of Muslim immigrants can transform Europe in 'Eurarabia' [29]. In 2006, a few months before her death, Oriana Fallaci was interviewed by The New Yorker, an event that contributes to international resonance to her anti-Muslim fundamentalism, stressing the comparison of Islam with Nazism and Fascism, the impossibility of dialogue and urging destruction of a mosque:

'They want to build damn mosques everywhere.' She spoke of a new mosque and Islamic center planned for Colle di Val d'Elsa, near Siena. She vowed that it would not remain standing. "If I'm alive, I will go to my friends in Carrara-you know, where there is the marble. They are all anarchists. With them, I take the explosives. I make you jump in the air. I blow it up! With the anarchists of Carrara. I do not want to see this mosque - it's very near my house in Tuscany. I do not want to see a twenty-four-meter minaret in the landscape of Giotto. When I cannot even wear a cross or carry a Bible in their country! So I BLOW IT UP!" [30].

A special case concerns the political scientist Giovanni Sartori, professor emeritus at the Columbia University in New York and at the University of Florence, columnist for the Corriere della Sera and intellectual of the center-left. His essay 'Pluralism, multiculturalism and foreign', published in 2000 [31], shows an unambiguous reasoning that is configured as an explicit model of 'academic Islamophobia' [26]. On the one hand, he proposes the essentialist representation of the Islamic religion as dogmatic, intolerant and marked by fanaticism; on the other hand, he focuses on the compatibility of Islamic immigrants to our 'cultural tradition'. In a passage of the essay he shows this qualitative leap that opens up a very problematic horizon about the possible integration:

'I'm wrong, for example, to argue that the immigrant Muslim is for us the farthest, the most alien and therefore the most difficult to integrate? If I'm wrong no one has shown me it. But not even I mistake in claiming that Muslim immigrants are fundamentalists at all' (cited in [26]). 
The invectives of Fallaci and the erudite reflections of Sartori serve up to the Italian conservative intellectual and political class a significant Islamophobic trend, reinforcing the political logic of building the internal enemy. Pulled by this rhetoric, a larger Islamophobic vision takes hold in an Italian racist landscape, investing the entire Islamic civilization. The first case regards Magdi Allam, a Muslim who recently converted to the Catholic faith with much fanfare, for years deputy director of Corriere della Sera and influential commentator on Islamic issues. In an article published in 2005, before his conversion, entitled 'Mosque-mania: need a stop', he calls, by virtue of his being a secular Muslim, for the suspension of the construction of mosques as they 'generate the brainwashing that turns human people into death's robots' [32]. The narrative used sustains the stereotype of the Muslim potential terrorist and of the Imam as a preacher of hate towards the West. This discourse is clearly oriented against the Islamic fundamentalism that provides for 'well-founded' fear that unites honest Muslims and Italians'.

The second one regards Marcello Pera, another well-known intellectual who moved from philosophical relativism to the conservatism by election in Italian Parliament with Berlusconi's party, Forza Italia. He published, in February 2006, a Manifesto called 'For the West, Force of Civilization' which, in total harmony with the clash of civilizations paradigm emphasizes the spiritual and moral crisis of the West incapable of responding to the challenge of terrorism and Islamic fundamentalism and "the commitment to reaffirm the value of Western civilization as a source of universal and inalienable principles, contrasting in the name of a common historical and cultural tradition, any attempt to build a Europe alternative or opposed to the United States' [33].

This is still the case of an intransigent rhetoric defending Western values against Islam, only shown in its fundamental dimensions, and interweaving both with the exaltation of Christian civilization and the negative image of the Italian left guilty of hating our civilization and handing it over to Islam, of being lenient with countries and terrorist groups and of being in favor of multiculturalism. Here, the image stemming from these neo-conservative positions is that of the global threat, of the invasion perpetrated by the terrifying world of Islam. These examples of intellectualism, clearly hostile to Islam and its embodiment in the Muslim migrants, pose a significant question: the formalization of a model of thought that nourishes a prejudiced common sense targeted against Islamic otherness and multicultural society (see also [24]). What unites these various interventions, before and after September 11, is an a-critical view of Islam seen as a single monolith, incompatible with the principles of democracy and freedom, very close to the differentialist thesis of the Samuel Huntington's clash of civilizations. The question is whether this representation in Italian public opinion has had a consensus, or if there are less hostile views to Islamic civilization than forms of prejudice connected to the proximity and visibility of Muslim migrants.

\section{The Two Latent Dimensions of Islamophobia}

Data collected by the survey show that the double dimension of Islamophobia above mentioned is well rooted. In fact the distribution of frequencies among the single items of Islamophobia scale reveals this double nature of anti-Muslim prejudice (Table 1): on the one hand, we note that public opinion is scared by the Muslim in 'flesh and blood'; on the other hand, people feel threatened by an entire and historical civilization. For the largest part of the sample, Muslims are intolerant, fanatical, anti-modernist, strongly closed in themselves, with a clear and powerful identity, scarcely loyal to 
the country in which they live, barely committed against terrorism. From the other side, Muslims are seen under the light — negative or positive — of their civilization, of the weight of culture and intellectual and scientific life in European tradition.

Table 1. Item frequencies of Islamophobia Scale.

\begin{tabular}{|c|c|c|c|c|c|}
\hline & False & $\begin{array}{c}\text { Probably } \\
\text { False }\end{array}$ & $\begin{array}{c}\text { Probably } \\
\text { True }\end{array}$ & True & Tot. \\
\hline Muslims are not very tolerant & 19.41 & 11.05 & 21.40 & 48.14 & 100 \\
\hline $\begin{array}{l}\text { Islam is a religion too traditional unable to } \\
\text { adapt to these times }\end{array}$ & 16.68 & 9.11 & 21.34 & 52.88 & 100 \\
\hline $\begin{array}{l}\text { Muslims prefer to associate with members of } \\
\text { their group in isolation from other }\end{array}$ & 18.95 & 9.08 & 21.30 & 50.67 & 100 \\
\hline $\begin{array}{l}\text { Muslims are more loyal to their } \\
\text { country of origin than to the country in } \\
\text { which they live }\end{array}$ & 14.35 & 8.76 & 19.43 & 57.45 & 100 \\
\hline $\begin{array}{l}\text { Islamic religious leaders are doing too little to } \\
\text { fight terrorism }\end{array}$ & 11.86 & 7.43 & 22.72 & 57.99 & 100 \\
\hline Islam is a threat to Christian civilization & 47.61 & 10.54 & 15.82 & 26.04 & 100 \\
\hline $\begin{array}{l}\text { Islam is a religion that has many values in } \\
\text { common with our }\end{array}$ & 33.28 & 14.60 & 20.39 & 31.72 & 100 \\
\hline European culture is superior to Islamic culture & 54.65 & 11.03 & 14.03 & 20.29 & 100 \\
\hline $\begin{array}{l}\text { It's right that we build places of } \\
\text { prayer for Muslims }\end{array}$ & 22.52 & 4.82 & 12.80 & 59.85 & 100 \\
\hline $\begin{array}{l}\text { The contribution of Islamic intellectuals to } \\
\text { European culture was important }\end{array}$ & 16.30 & 10.38 & 23.86 & 49.46 & 100 \\
\hline
\end{tabular}

In this double perspective, some data illustrate how widespread is the typical representation of Muslim as a subject that expresses great distance from our lifestyles and values. For example, the closure of Islamic communities and their loyalty to the country of origin is a tangible sign of the plausibility of the discourse on the difficulty of integrating Islamic immigrants to Italian society.

Some others illustrate that Islam considered in its overall dimension of civilization arouses more positive feelings. In fact, there is a polarization between two positions: one that does not feel threatened by the Islamic civilization, believes that Islamic culture was important for European culture and, above all, that it is not inferior to ours and is able to convey values similar to the ourselves; vice versa, a second position expresses a high level of incompatibility and the perceived threat of Islamic civilization. Moreover, positions regarding the construction of mosques confirm this ambivalence. Only a clear minority expresses its opposition to the mosque building, outcomes that show how protests and mobilizations manipulated by the Northern League involve only a livid minority. This distinction is confirmed by the factorial analysis of the Islamophobia scale, which shows two separate factors in line with what is stated on the analysis of frequencies of individual items $^{1}$ (Table 2). The first dimension or indicator consists of those items related to the aforementioned characteristics of closeness, intolerance, traditionalism, and anti-modernism

1 The Kaiser-Meyer-Olkin (KMO) measure of sampling adequacy is large 0.889 , and the Bartlett's Test of Sphericity is 0.000 . These results indicate that is reasonable to proceed with factor analysis. 
holding hostile attitudes towards Muslims considered a homogeneous group negatively defined, while the second factor evokes feelings regarding Islamic culture and religion in its generality, belief that results in less prejudice than the previous one. The items forming these two separate dimensions are quite homogeneous, except perhaps for two sentences that might be deemed dissimilar: item 2 (Islam is a religion too traditional unable to adapt to these times), and item 9 (It's right that we build places of prayer for Muslims). The explanation for this apparent discrepancy may be of both a statistical and cognitive nature. From a statistical perspective, if we remove those two items, outcomes of factor analysis are the same, namely the significance of the two groups does not change. On the cognitive level, we can say that respondents may have understood the questions in the same direction as here emphasized. The charge of conservatism against Muslims could be used as the explanation for certain events associated with patriarchal customs (such as the killing of young women who wanted to marry an Italian guy) or with external signs brought by Muslim people such as the Hijab of Muslim women. In this view, conservatism does not refer to an abstract dimension but to the concreteness of everyday behavior of subjects considered Muslims. The item on mosques is perhaps one of the most discussed in literature. The substantial agreement of the sample with the sentence is interesting because it shows a degree of religious tolerance likely depending on the fact that Islam is a legitimate monotheistic religion with a long history. Here, we don't find discomfort for the building of a mosque, but the adherence to a principle of religious freedom, which is well adapted to the second dimension of Islamophobia that we detected.

Here the problem is to understand the nature of this polarization, which shows also diverging rates of hostility: the first dimension records more hostility than the second one. We can affirm that the first indicator is more able to represent attitudes against Muslims as 'internal enemy or threat'. The second indicator recognizes Islam as an 'external and threatening enemy' and it is less shared by Italian public opinion. The first dimension appears strongly supported by the negative image of Muslim individuals and communities as visible elements bearing an irreducible cultural distance; conversely, when Islam is considered in its cultural and religious dimension that image weakens. We can say that Islam in its version of the "clash of civilizations" breaches the conservative political side, which in turn shows preference toward authoritarian and ethnocentric attitudes that are important in shaping the racial prejudice. 
Table 2. Factor Loading for anti-Muslim Attitude Scale *.

\begin{tabular}{lcc}
\hline & Factor 1 & Factor 2 \\
\hline $\begin{array}{l}\text { The Muslims are not very tolerant } \\
\text { Islam is a religion too traditional and unable to adapt to these }\end{array}$ & 0.63458 & \\
times & 0.62955 & \\
$\begin{array}{l}\text { Muslims prefer to associate with members of their group in } \\
\text { isolation from other }\end{array}$ & 0.63217 & \\
Muslims are more loyal to their country of origin than to the & 0.63911 & \\
country in which they live & 0.66359 & 0.57038 \\
Islamic religious leaders are too hesitant to fight terrorism & & 0.63287 \\
Islam is a threat to Christian civilization & & 0.51231 \\
Islam is a religion that has many values in common with ours & & 0.64210 \\
$\begin{array}{l}\text { European culture is superior to Islamic culture } \\
\text { It's right that we build places of prayer for Muslims } \\
\text { The contribution of Islamic intellectuals to European culture was } \\
\text { important }\end{array}$ & & 0.71217 \\
\hline
\end{tabular}

The responses (Table 3) were then reclassified on four classes or scores through a uniform system of allocation of points in which higher scores were expressing Islamophobia. This re-classification has allowed us to identify four clusters of attitudes (see for another interesting classification [34]):

(1) tolerant

(2) indifferent/neutral

(3) loyal with prejudice

(4) intolerant

These categories try to capture the different and often ambivalent feelings, which are at work among people. We use the term 'tolerant' in a way very close to Michael Walzer [35]. For him, tolerant people are those who have no difficulty making room for men and women whose beliefs they do not accept, nor try to imitate their practices; people living with otherness whose presence in the world they approve of, but which still remains an element far from their experience. Among tolerants, we include of course even those who enthusiastically endorse the differences we might call 'xenophile'. Tolerants are mainly people with a good level of education and center/left position.

The terms indifferent/neutral combine two types of social distance identified by Bogardus [36]. The pattern of indifference and neutrality is based on the absence of social contacts with members of other groups, on a permanent separation from those racial groups that they do not understand, on the lack of (positive or negative) emotional reactions. No new experience can change their alleged neutrality and indifference to the other groups. Here, people with higher education level and positioned at the center/left of the political spectrum are more likely neutral.

The loyalist model comes from a strong sense of loyalty to the belonging "racial" community, which often hides the vices and defects of the members of their same group, thus, creating an immutable social distance [36]. A complex of overestimated superiority leads many people to attitudes of superiority towards the less fortunate races. Behaviors of prejudiced paternalism characterize this type of person, especially if their social status is not threatened by the "inferior 
races". Here we may note that high, medium, and low levels of education are equally represented, while center-right positions are generally more widespread than the center-left.

The intolerant model comes from a combination of different but homogeneous attitudes: a sense of superiority; the belief that the other races are intrinsically different and alien; the idea of having an exclusive right in certain areas of privilege and advantage, and the fear and suspicion of the subordinate races full of projects in order to weaken the prerogatives of the dominant race [37]. Here people with lower education level and positioned at the center/right are more likely intolerant.

Table 3. Frequencies level of Hostility against Islamics (\%).

\begin{tabular}{lc}
\hline Tolerant & 4.77 \\
Indifferent/neutral & 16.36 \\
Loyal with prejudice & 40.75 \\
Intolerant & 38.12 \\
Total & 100.00 \\
\hline
\end{tabular}

At the general level, we may assert from the point of view of main socio-demographic variables (age, gender, cultural capital, and class) that older people have more widespread negative attitudes than younger ones, and education plays an important role: the lower the cultural capital is, the more often the attitude is negative; gender is not so meaningful, while anti-Muslim feelings are equally distributed among all social classes. In general, a greater openness to Islam by young and well-educated people is confirmed.

A particular importance regards the influence exerted by political affiliation on racial prejudice. People that express an orientation toward the center/left are more tolerant than those oriented to the center/right. These latter confirm their hostility toward both the internal dimension of threat and the external one connected with the "clash of civilization" syndrome. However it should be noted that an important part of the center-left political orientation ( $34 \%$ of sample) agrees intolerant attitude concerning the "internal threat" indicator, although it is tempered by a greater openness on the second indicator.

\section{The Overlapping between Islamophobia and Antisemitism}

Our idea is that we are facing a racism that changes easily its targets reproducing a well-known morphology. It is confirmed by the fact that the $45 \%$ of the sample cultivates simultaneously prejudice against Muslims and Jews. This idea pays a tribute to Robert Fine argument sustaining that recently there has been a "methodological separatism" in the field of racial and ethnic studies, which split the study of Islamophobia, Antisemitism, and other kind of racisms in different and often oppositional areas [38]. It is a remarkable outcome of our survey the identification of a strong connection between these two kinds of racism, as noted in other researches [39]. Meer and Modood argue that there are important analogies in the racial content of Antisemitism and anti-Muslim sentiment or Islamophobia [14,40]. A comparison of Antisemitism and anti-Muslim sentiment could promise novel insights not only into our understanding of both, but also into the interpretation of the widely racialized dynamics which embrace our multicultural societies. This strong similarity and overlapping of Antisemitism and Islamophobia (see Table 4) should be explained by the plastic 
nature of the new racism. Jews and Muslims, although with differing percentages, are targets of a single racial prejudice, characterized by indifference to its victims and an alarming transitive property that makes it move easily from one target to another. We face the emergence of a public racist discourse that sees the bearer of different symbols and beliefs, the "otherwise" Italian or European, a threat for the majority cultural homogeneity and for the sense of group position. Almost $45 \%$ of our sample expresses attitudes against Jews and Muslims, while only $15 \%$ is tolerant. Furthermore the $65 \%$ of those who show anti-Muslim feelings are at the same time anti-Semitic, while $91 \%$ of those who show anti-Semitic attitudes are at the same time anti-Muslim.

Table 4. Frequencies overlapping hostility against Jews and Muslims.

\begin{tabular}{ccc}
\hline & Frequencies & $\mathbf{\%}$ \\
\hline Pro Jews, Pro Muslims & 223 & 14.66 \\
Against Jews, Pro Muslims & 99 & 6.47 \\
Pro Jews, Against Muslims & 520 & 34.12 \\
Against Jews and Muslims & 681 & 44.75 \\
Total & 1523 & 100.00 \\
\hline
\end{tabular}

One might call this phenomenon an 'indiscriminate discrimination' or a 'systemic and generalized racism' or again as we have, 'liquid racism'. The overlap between the two forms of prejudice suggests some thoughts. On the one hand it shows that, at least in this country, prejudice and racism unfolds along similar and symmetrical models. The two groups are perceived hostile based on similar characters. Both groups are considered closed, little tolerant, loyal to foreign countries, especially traditionalist and immutable. Of course, nobody denies them a place to pray, just as their contribution to European culture it is not in discussion. But both are undergoing a process of essentialization or racialization. Secondly, one can see that the two groups are not perceived as actors of a conflict where one or the other may have reasons on their side to justify their mutual animosity. Unlike those who think that judgments on the two groups are fuelled by polarized ideologies - something that is confirmed for $40 \%$ of the sample and probably for reasons that go beyond the ideological tensions produced by the conflict between Palestinians and Israelis - $60 \%$ expresses similar opinions on both groups.

It may be noted here that in history, waves of racism occur which change their target from one group to another. Antisemitism is a historical form of racism so elaborate that it constitutes a model for the racialization of other groups. Racism against Muslims shares the same pattern of antiJewish racism, as it would appear that anti-Romaism, which is becoming the prevalent racism, spread on the basis of a model once more similar to that forged by Antisemitism.

Finally, as noted by some anthropologists, Jews and Muslims share, in the light of detractors, some dystonic and opposing attitudes towards globalizing modernization, such as preferences for food processed on the basis of principles of worship, for religious and traditional garments, for more or less esoteric and secret traditions, and the fact of being monotheistic religions in competition with Christianity. All aspects that cast over the two groups, at least in this country, a shadow of prejudice and vilification. 


\section{Predictors for Antisemitism and Islamophobia}

In the social-psychological and sociological research different prediction models of racism are used. Dekker e van der Noll [5] used for example as a predicting model of prejudicial attitudes a combination of three processes: direct contact, socialization and attitudes' self-generation through inference processes (see also [41]). In the case of Zick, Küpper and Wolf [42], the focus was on the Group-focused Enmity syndrome and the predictors were six different elements: anti-immigrant attitudes, Antisemitism, anti-Muslim attitudes, racism, sexism, and prejudice towards homosexual persons.

Differently from these researches, we tested a more classical model based on ideological dimensions, which however entail behavior and practices. Our research design was based from the outset on the idea that the intolerant conduct, in this case against Muslims and Jews, is dependent on other components of the system of beliefs, attitudes and practices of social actors. This viewpoint was first tested a high level of reflection and empirical research by Adorno, Levinson and colleagues in the famous research on authoritarian personality. Usually, this system of ideas is called ideology, but this term, since its coinage, has changed over time gaining multiple and divergent meanings. Some scholars, reviewing the dimensions of ideology, gave to the concept a twist of cognitive nature that makes it a more useful and high rank research tool. A cognitive angle was also present in the research of Adorno and colleagues: in the Introduction it is said that "ideology is the term used in this volume in the common meaning in current literature, under which it designates an organization of opinions, attitudes and values a way of thinking about man and society" ([43], p. 18). But their interest was primarily oriented to explaining the correlations between ideology and individual personality, whereas the latter factor mediates the sociological influences on ideology and attitudes. Some components of the ideology that influence the racist views and attitudes have long been believed by social scientists to be those of ethnocentrism and authoritarianism. To these two predictors we have added one further explanatory variable, used repeatedly in research on racism, but more structural and situational, which we call anomie.

According to these underlying assumptions, research shows that racism is the result of three large collective phenomena or conditions that mark Italian society:

- A widespread ethnocentrism and nationalism, which seems to feed a strong national or regional or ethnic identity is present in a large proportion of respondents. We argue that the ethno-national identity is a circumstance that favors the occurrence of prejudice. At the same time and in a recursive or circular logic, the anti-Semitic and anti-Muslim prejudice contributes to national unity in a classical dynamic based on the identification of a threatening out-group.

- A widespread authoritarianism, which is a reaction to anxieties and insecurities both individual and collective. Under conditions of particular uncertainty and social fragmentation, authoritarianism becomes a flight "from freedom" and from the individual and collective responsibility; it crystallizes in punitive attitudes and an obsessive request for compliance. In the same recursive perspective first outlined, authoritarianism enter into a relationship of "reciprocal causality" with prejudice, making this latter a functional substitute for the social and juridical covenant that should ensure social harmony and social cohesion [44]. Racism is, thus, not only 
the source for new social ties, but also a tool to deal with the crisis of the rule of law. Here lies the thrust for the drive towards assimilation.

- A widespread situation of anomie, or social uncertainty and distrust, which feeds the prejudice and produces the conditions for racism, is the starting point for new forms of social solidarity, backed now on an aggressive but short-lived ethno-racial identity. In this case we have split up anomie in two diverging dimensions: distrust of the future and distrust of society, alluding the former to a condition of complete uncertainty toward the near upcoming individual and familiar condition; the latter referring to a contingent situation of absence of social supports and solidarity. In all three cases there is clear evidence that the lower the cultural capital and social status, the stronger the authoritarian, ethnocentric and distrust attitudes.

In our research we tested the strength of these three predictors (Authoritarianism, Ethnocentrism, and Anomie), made from its scales, with the aid of path technique based on multiple regression analysis which helps to determine the direct and indirect impacts of certain independent variables on dependent variables in a hypothetical causal system. From the multiple regressions, coefficients are obtained that indicate the strength of this effect, called beta coefficients.

Authoritarianism and ethnocentrism, which are highly correlated $(+0.61)$, explain clearly the intolerance toward Muslims and Jews. The more one is authoritarian and ethnocentric, the greater is one's level of intolerance towards Muslims and Jews ( $\beta$ coefficient $=0.27$ and $\beta=0.28$ ). In this model, the distrust of the future is not in a significant causal relationship with intolerance because it is mediated by the other two indicators, with which it is strongly correlated: +0.45 with authoritarianism and +0.41 with ethnocentrism.

From the presentation of the various diagrams showing the direct and indirect effects of the three main predicting variables of the model we can make some evaluations. First, the authoritarian attitude proves to be a decisive factor in shaping negative opinion of Jews and Muslims, in line with several other research studies. Even ethnocentrism reinforces the injury due to the high correlation between these two variables. Undoubtedly, expressing opinions of an authoritarian model easily connects to the emergence of attitudes that favor a positive vision of subjects' own hegemonic group identity. In the sociological dialectic between in-groups and out-groups, such attitudes are often the result of a series of historically specific social circumstances, which increase the flow. In other words, the relationship between authoritarianism, ethnocentrism, intolerance, and prejudice against Muslims and Jews should not lead us to think in terms of specific personality, but rather to reflect on the current social and economic situation of our society and how it promotes the emergence of these attitudes, especially in those people that belong to the right of the political spectrum. Anomie has no direct effect on intolerance, it is nevertheless a condition that feeds an authoritarian and ethnocentric perspective, which provides "good reasons" and structural conditions for the occurrence of prejudice and racism. In essence, anomie acts as carrier of resentment that feeds on the legitimacy of authoritarian and ethnocentric reasons.

It is however important to note (Figures 1 and 2) that the two predictors consideredauthoritarianism and ethnocentrism - act on prejudice against Jews and Muslims in a different, if not completely opposite manner. In the case of Antisemitism, authoritarianism turns out to be less important than ethnocentrism, thus revealing a nationalist prejudice fed by a special sense of irreducible distance between cultures. In the case of Islamophobia, authoritarianism prevails 
instead in the causal relation, confirming, as argued earlier, that prejudice against Muslims is more closely linked to a sense of social disorder, to the feeling that people of Islam religion are in themselves threatening or dangerous. Authoritarianism is a syndrome embraced especially by the lower class. It is likely that the social frustration generates growing demands for conformity, justicialism, hierarchy and control of outsiders. Authoritarians claim for a well-ordered society where "others", here identified with Muslims, must occupy their fated social position avoiding any voice for rights. Ethnocentric people feel Jews as high-level competitors bearing privileges naturally stemming from ethno-national origin and belonging. Insofar as Muslims are seen as a threat of natural social order and so are matter of hierarchy, Jews are felt as competitors belonging to another but privileged ethnic minority and so are matter of national loyalty.

Figure 1. Path between Authoritarianism, Ethnocentrism, Distrust in the future and Intolerance towards Jews $(\mathrm{R}$-square $=0.18)$.

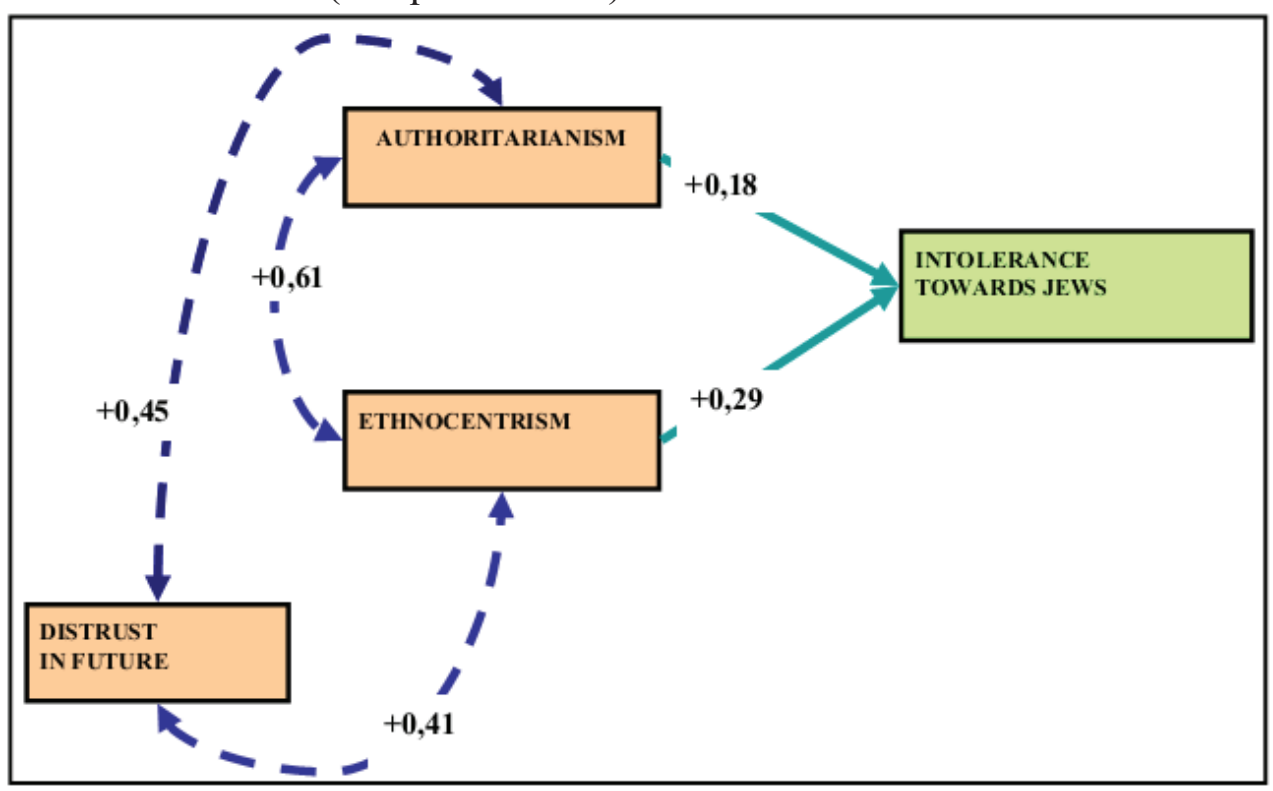

Figure 2. Path between Authoritarianism, Ethnocentrism, Distrust in the future and Intolerance towards Muslims (R-square $=0.15)$.

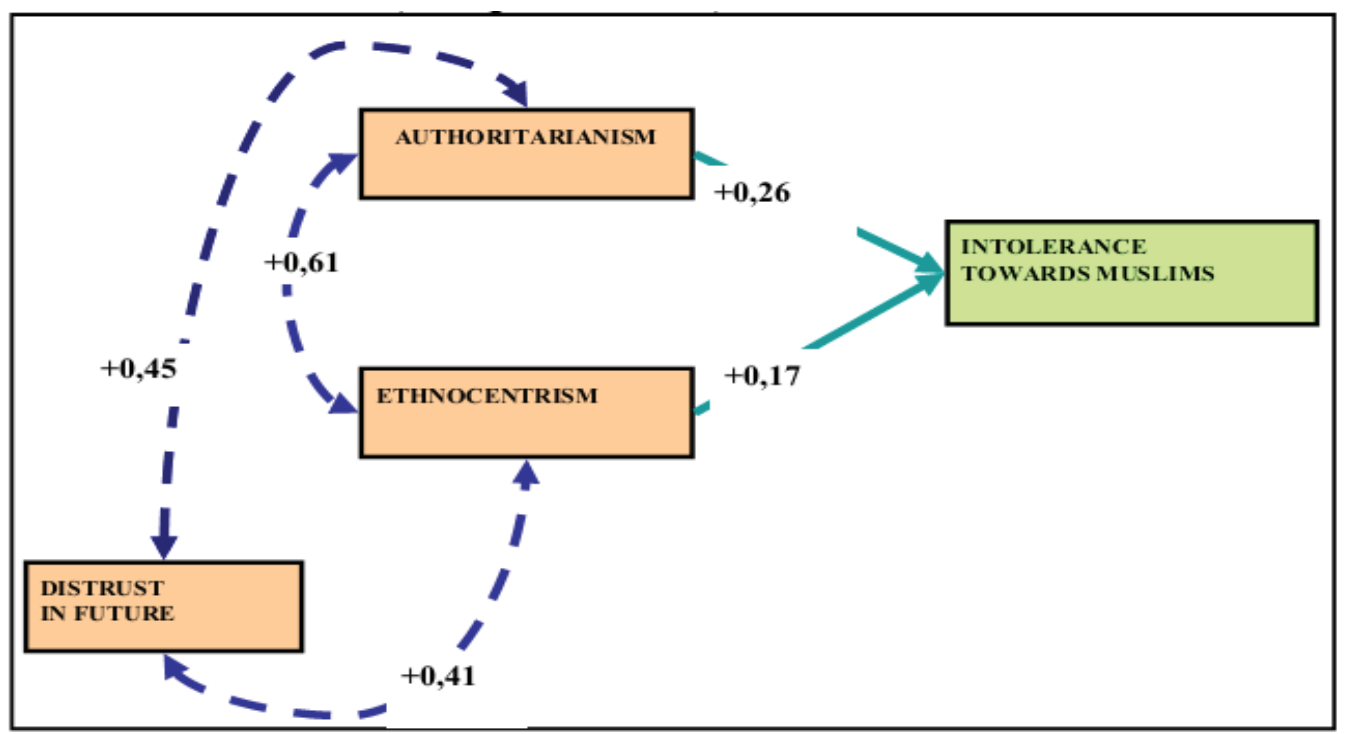




\section{Conclusions}

The research here summarized casts a glance on the pervasiveness of prejudice in Italy, a phenomenon that is often underestimated, if not entirely denied. The firm denial that racist attitudes exist poses a double problem: on the one hand, this denial takes the form of self-exculpatory behaviours considered limited to minority racially or ideologically extreme situations that may also justify certain attitudes, and second, that denial is a proper strategy which, by denying the evidence of harmful policies, speeches, statements, does not openly violate the order of public discourse, which obviously is not racist. The latter strategy generalizes the classical assertion that individuals use to excuse themselves from guilt: 'I'm no racist, but...', and surreptitiously undermines the anti-racist public discourse.

This research illuminates a reality consisting of deep-rooted and pervasive hostile attitudes targeted both toward minorities such as Jews, which we believed had vanished from the ideological horizon of the citizens of democratic societies, or to new internal enemies that can be identified in Muslims. These prejudices have grown slowly over the time, scarcely contrasted, supported by coarse, but clear, discourses and ideologies, diffused by media and by, so called, "political entrepreneurs of racism". Furthermore, this trend has grown on the basis of widespread authoritarianism, ethnocentrism, and social distrust, which mark these collectivities expressing fear of the future and living (or feeling) a deeply socio-economic uncertainty. Feelings of fear and distrust find in racism and prejudice a "safety valve", especially among popular classes, and people with scarce cultural resources, who are more vulnerable facing a generalized political and economic crisis. The collected data show some further points:

- In the horizon of the new racism Antisemitism has to be understood as racism, perhaps as the archetypal form of the new differentialist racism.

- Antisemitism and Islamophobia have to be considered as the same family of racial prejudices. Obviously different in some aspects, they however share a long sequence of similarities regarding the folkways evoked and the discourses subtly diffused.

- Behind the term Islamophobia are two different but correlated dimensions, the first leading to a "phobia" which easily transforms into racism discriminating against Muslim individuals and communities, the second leading to a hostility against Islam as civilization which is older in its features.

- Racism is becoming not only a widespread but disorganized and confused arrangement of prejudicial attitudes. It is becoming something more structured, something that we can call a social bonding in order to substitute different forms of social organization such as the rule of law or class solidarity and cohesion.

The data here commented on ask unavoidable questions mainly to anti-racist people, because they show how anti-racism, mainly because of an irresistible trend of ideological reproduction, is almost totally ineffective in curbing racism. The current anti-racism has become a pale replica of the great mobilization and critical skills that marked the years immediately following World War II, when the racism to be fought was much more evident on both the ideological and political sides, 
consisting of the extermination Jews, Gypsies, and other minorities. The current racism that hides behind phenomena such as social insecurity, or at the back of discourses such as the authenticity of cultures and their natural hierarchies, is very different from the explicit racism of the early twentieth century, but it is quickly becoming a common sense, which is already part of the public discourse. To combat it we need thin and insightful tools, able to deconstruct the self-evident argument as to who is racist and to pierce the veil of ignorance that envelops the racists - "by choice" and "by chance" - and the anti-racists who want to fight them. More appropriate then, would be a more courageous and compelling critique of the political ideologies and institutional practices that often fuel hostility.

\section{Conflicts of Interest}

The authors declare no conflict of interest.

\section{References}

1. Allen, Chris. Islamophobia. Ashgate: Aldershot, 2010.

2. Padovan, Dario, and Alfredo Alietti. "The racialization of public discourse." European Societies 14, no. 2, (2012): 186-202.

3. The Runnymede Trust. Islamophobia: A Challenge for Us All. London: Runnymede Trust, 1997.

4. Halliday, Fred. "'Islamophobia' reconsidered." Ethnic and Racial Studies 22, no. 5 (1999): 892-902.

5. Dekker, Henk, and Jolanda van der Noll. "Islamophobia and Its Origins." Paper Prepared for Presentation at the fourth ECPR Conference, Pisa, Italy, 6-8 September 2007.

6. Iqbal, Zafar. "Understanding islamophobia: Conceptualizing and measuring the construct." European Journal of Social Sciences 13, no. 4 (2010): 574-90.

7. Heitmeyer, Wilhelm, and Andreas Zick. "Anti-semitism, islamophobia and group-focused enmity in Germany." Research Note. Institute for Interdisciplinary Research on Conflict and Violence. University of Bielefeld May 2004.

8. Taguieff, Pierre-André. La Forcedu Préjugé. Essai sur le Racisme et ses Doubles. Paris: La Découverte, 1998.

9. Balibar, Etienne, and Immanuel Wallerstein. Race Nation Classe. Paris: Edition La Découverte, 1988.

10. Goldberg, David Theo. "Racial Europeanization." Ethnic and Racial Studies 29, no. 2 (2006): 331-64.

11. Werbner, Pnina. "Islamophobia. Incitement to religious hatred - legislating for a new fear?" Anthropology Today 21, no. 1 (2005): 5-9.

12. Sivanandan, Ambalavaner. "Poverty is the new black, in the three faces of British Racism." Special Issue of Race \& Class 43, no. 2 (2001): 1-5.

13. Fekete, Liz. "Anti-muslim racism and the European security state." Race \& Class 46, no. 1 (2004): 3-29.

14. Meer, Nasar, and Tehseen Noorani. "A sociological comparison of anti-Semitism and anti-Muslim sentiment in Britain.” The Sociological Review 56, no. 2 (2008): 195-219. 
15. Roald, Anne Sofie. "Majority versus Minority: 'Governmentality' and Muslims in Sweden." Religions 4 (2013): 116-31.

16. Allievi, Stefano. "Europe's Muslim Communities: Security and Integration post 11 September". The Italian Report, 2006. Research report not published.

17. Allievi, Stefano, ed. I Musulmani e la Società Italiana. Milano: Franco Angeli, 2009.

18. Guolo, Renzo. Xenofobi e Xenofili. Gli Italiani e L'islam. Laterza: Roma-Bari, 2003.

19. Biorcio, Roberto. La Padania Promessa. La Storia, le Idee e la Logica d'azione Della Lega Nord. Milano: Il Saggiatore, 1997.

20. Biorcio, Roberto, and Tommaso Vitale. "Culture, Values and Social Basis of Northern Italian Centrifugal Regionalism. A Contextual Political Analysis of the Lega Nord." In Contemporary Centrifugal Regionalism: Comparing Flanders and Northern Italy. Edited by Michel Huysseune. Brussels: The Royal Flemish Academy of Belgium for Science and the Arts Press, 2010, pp. 171-99.

21. Taguieff, Pierre-André. L'illusion Populiste. Paris: Berg International Editeurs, 2002.

22. Diamanti, Ilvo. La Lega. Geografia, Storia e Sociologia di un Soggetto Politico. Roma: Donzelli, 1990.

23. Laclau, Ernesto. On Populism Reason. London: Verso, 2005.

24. Cousin, Bruno, and Tommaso Vitale. "Italian Intellectuals and the Promotion of Islamophobia after 9/11." In Global Islamophobia: Muslims and Moral Panic in the West. Edited by George Morgan and Scott Poynting. Aldershot: Ashgate, 2012, pp. 47-66.

25. Massari, Monica. Islamofobia. La paura e l'islam. Laterza: Roma-Bari, 2006.

26. Sciortino, Giuseppe. "Islamofobia all'italiana." Polis 1 (2002): 103-23.

27. Open Society Institute. "Monitoring Report of minority protection in the European Union: the Situation of Muslims in Italy". Open Society, 2002, www.eumap.org/reports/2002/eu/ internationalsectionsitaly 2002 m_italy.pdf.

28. Fallaci, Oriana. La Rabbia e l'orgoglio. Milano: Rizzoli, 2001.

29. Fallaci Oriana. La Forza Della Ragione. Milano: Rizzoli, 2004.

30. Talbot, Margaret. "The Agitator. OrianaFallaci directs her fury towards Islam." The New Yorker, 5 June 2006. http://www.newyorker.com/archive/2006/06/05/060605fa_fact.

31. Sartori, Giovanni. Pluralismo, Multiculturalismo e Estranei. Saggio Sulla Società Multietnica. Milano: Rizzoli, 2000.

32. Allam, Magdi. "Moschea-mania, serve uno stop." Corriere della Sera, 29 September 2005, 15.

33. Pera, Marcello. "Manifesto for the West." 23 February 2006. Available online: www.perloccidente.it/index.php (accessed on 23 April 2013).

34. Hassan, Leone. Un Pregiudizio Multiforme. Institute Cedec-Ispo, January 2007. Research report not published.

35. Walzer, Michael. On Toleration. London and New Haven: Yale University Press, 1997.

36. Bogardus, Edgar. S. "Mutations of social distance." Journal of Applied Sociology 11, no. 1, (1926): 77-84.

37. Blumer, Herbert. "Race prejudice as a sense of group position." The Pacific Sociological Review 1, no. 1 (1956): 3-7. 
38. Fine, Robert, and Glynis Cousin. "A common cause. Reconnecting the study of racism and Antisemitism." European Societies 14 (2012): 1-20.

39. Graf, Wilfried. "Das neue faschismus-syndrom: die gemeinsame tiefenkultur von antisemitismus und islamophobie." Psychotherapie Forum 14 (2006): 102-07.

40. Meer, Nasar, and Tariq Modood. "For "Jewish" read "Muslim"? Islamophobia as a form of racialisation of ethno-religious groups in britain today." Islamophobia Studies Journal 1, no. 1 (2012): 34-53.

41. Ajzen, Isek, and Martin Fishbein, eds. Understanding Attitudes and Predicting Social Behaviour. New Jersey: Prentice-Hall, 1980.

42. Zick, Andreas, Küpper Beate, and Wolf Hinna. "European conditions. Findings of a study on group-focused enmity in Europe." Institute for Interdisciplinary Research on Conflict and Violence. University of Bielefeld: http://www.amadeu-antonio-stiftung.de/w/files/pdfs/ gfepressrelease_english.pdf. 2009.

43. Adorno, W. Theodor, Frenkel-Brunswick Else, Levinson J. Daniel, and Sanford R. Nevitt. The Authoritarian Personality. New York: Harper, 1950.

44. Sniderman, Paul M., Peri Pierangelo, Rui J. P. de Figuerido, and Piazza Thomas. The Outsider: Prejudice and Politics in Italy. Princeton, NJ: Princeton University Press, 2000. 


\title{
Has Multiculturalism Really Failed? A Canadian Muslim Perspective
}

\author{
Baljit Nagra and Ito Peng
}

\begin{abstract}
In recent years, claims that multiculturalism has created segregated communities, encouraged terrorism, and failed to foster shared national identities in western nations have gained popularity. In this paper, we use young Canadian Muslims' lived experience of multiculturalism to reflect on this debate. Contrary to popular rhetoric, our interviews of 50 young Muslim adults show that many maintain a dual Canadian-Muslim identity by utilizing the ideology of multiculturalism, even though they are increasingly stigmatized for their religion. These findings lead us to problematize the discourse surrounding the 'failure' of multiculturalism and to highlight the contradictions within it.
\end{abstract}

Reprinted from Religions. Cite as: Nagra, B.; Peng, I. "Has Multiculturalism Really Failed? A Canadian Muslim Perspective." Religions 4 (2013): 603-620.

\section{Introduction}

On February 5, 2011, at the Annual Munich Security Conference, British Prime Minister David Cameron declared: 'State multiculturalism has failed' [1]. According to Cameron, multiculturalism creates segregated communities, encourages terrorism and fails to provide a shared sense of British identity. In his speech, he also warned of increased scrutiny of Muslim groups receiving public money but not tackling extremism [1]. Cameron's comments followed hard on the heels of similar warnings from German Chancellor Angela Merkel and French President Nicolas Sarkozy [2]. Their sentiments are reinforced by rapidly shifting multiculturalism policies and discourses worldwide. Some critics note the return of assimilationist policies and a rejection of pluralism in such countries as the US, Germany and the Netherlands [3,4], while others see recent emergent political consensus in Western Europe as a recalibration rather a rejection of multiculturalism [5].

The recent disenchantment with multiculturalism in both Europe and North America has been fuelled by anxieties about Islam and fears about security following 9/11 [6]. The catastrophic events of 9/11 significantly altered how Muslim communities are seen worldwide [7,8]. Islam has long been subjected to orientalist depictions but following 9/11, Muslim communities were projected as a threat to the very existence of western civilizations [9] in ascending order please. In Canada, there was a 16-fold increase in hate crimes directed towards Muslims in the year following 9/11 [7]. Many western nations, including Canada, implemented anti-terrorist laws targeted at Muslims. Canada's Bill C36, introduced approximately two months after 9/11 [7,9,10], modified 22 existing laws, including the criminal code, and led to the creation of new criminal offenses such 
as facilitating and enticing terrorist acts [7,11]. The implementation of anti-terrorist legislation also coincided with fears that multiculturalism could foster terrorism. For instance, Robert Fulford ([12], A19), columnist for a major Canadian newspaper, National Post, asks 'How can multiculturalism which preaches tolerance above all else-be squared with a militant, intolerable creed that demonizes non-believers?'

Since Muslim communities are at the forefront of debates about multiculturalism, and Canada is often perceived as the world leader in multiculturalism (having been the first western nation to officially adopt a multicultural policy), it seems appropriate to study young Canadian Muslims to clarify the dynamics of multiculturalism. Because $9 / 11$ was a critical turning point in world politics, resulting in a noticeable shift in the state's and society's attitudes towards and relationships to Muslim communities, the post 9/11 experiences of Canadians Muslims opens a window on multiculturalism and how it works both as an idea and as a practice. Furthermore, by focusing on Canadian Muslims, we can fill a gap in empirical data, as the treatment of Muslim communities in Canada post 9/11 has largely been ignored in academic literature.

In our in-depth interviews of 50 young Muslims, we found that young Canadian Muslims are increasingly stigmatized and marginalized for their religion. Their Muslim identity is often a target of discrimination and abuse in public spaces. Institutions such as the labor market and state security practices seem to have become more discriminatory towards Canadian Muslims. Interestingly, many young Canadian Muslims are using the ideology of multiculturalism to resist discrimination and pressures to assimilate, and proudly retain a dual Muslim and Canadian identity. This obvious contradiction between the reality of racial and ethnic discrimination and ideology of multiculturalism yields important insights into the ground level dynamics of multicultural negotiations. Our study suggests that in Canada, multiculturalism is not a given reality but an everyday micro-contestation; furthermore, the increased public scrutiny of Muslims after 9/11 helped them articulate and embrace multiculturalism.

These findings lead us to problematize the discourse surrounding the 'failure' of multiculturalism, and to highlight its inherent tensions. Though multiculturalism is often understood as a means to ensure diversity and equality [13], many academics argue that its core objective is to assimilate minorities to the dominant culture [9,14-17], a sentiment supported by our findings. If this is the case, we argue that the 'failure' of multiculturalism might have more to do with Muslim resistance to assimilation than their ability to maintain loyalties to western nations. In the post $9 / 11$ era, the retention of Muslim identities in western nations may not be welcomed because of how Islam has been demonized, as illustrated by increasingly explicit government policies of zero tolerance of Muslim religious and cultural practices, along with popular public support of these policies. For example, the most recent debate of a ban on religious symbols in Quebec.

In the next section, we review European discourses that suggest a growing endorsement of assimilationist policies. These are interesting because of their distinct focus on ethnic and religious immigrants, and more precisely, Muslims, differentiating them from the race and class dominated multiculturalism and immigration discourses in Canada and the US. In the third section, we provide an overview of the Canadian literature on multiculturalism including its critiques. The fourth section explains our research methods, and in the fifth, we show how multiculturalism plays out in the daily lives of young Canadian Muslims. Here we show how young Muslims face pressures to 
assimilate as they navigate through public spaces and institutions, but use multiculturalism to resist discrimination by asserting both their Muslim and Canadian identities. Finally, we conclude with a discussion of what these experiences tell us about current debates surrounding multiculturalism and its inherent contradictions. We suggest that the discourse surrounding the 'failure' of multiculturalism is not neutral but racialized, highly influenced by the post 9/11 social and political context.

\section{Discourses of Multiculturalism in Europe}

European multicultural debates are particularly relevant for this study because of their focus on Muslim ethnicity and religion. They provide an important contrast to debates on multiculturalism in Canada and offer valuable insights into how race, ethnicity, and religion intersect in multicultural discourses about Muslims.

In contrast to the growing support for multiculturalism in the 1970s and 1980s, the 1990s and 2000s saw a multiculturalism backlash [18]. In many European countries, a growing belief in the failure of multiculturalism led to policy retreat $[3,18,19]$, with multiculturalism being blamed for ethnic segregation, social isolation of immigrants, and weakened national identity [4]. Some even argue that the combination of multicultural policies promoting cultural diversity and access to generous welfare support for immigrants have, instead of facilitating immigrant integration and social citizenship, led to increased welfare dependence and social and economic marginalization [20].

In the Netherlands, until recently one of the most pro-multicultural countries in the EU, for example, the government began to balk on its Minderhedennota policy (minority policy) in the 1990s, as media and political discourses took an anti-immigration and anti-multicultural turn. The minority policy gave resident immigrants a wide range of citizenship rights, including access to civil services and local voting rights and support for cultural associations. The policy also developed an institutional framework for immigrants to access political and policy decision-making, such as the creation of consultative immigrants' councils, and introduced education and employment programs and policies against racial discrimination [21]. These policies and programs, however, met with growing criticism in the 1990s, from both the political right and left, for being ineffective and for promoting social segregation. Critics argued that despite the multicultural policy, the immigrant unemployment rate remained high, and immigrants appeared to have made little progress integrating into Dutch society. In 'Multicultural Drama', vocal critic Paul Scheffer called the multicultural experiment bankrupt and argued for the need to rethink immigrant integration in Dutch society $[5,22]$. In response to these criticisms, the Dutch government shifted its policy focus from celebrating cultural and language diversities to labor market integration. Such programs as obligatory Dutch language and social orientation for newcomers were introduced in an effort to better assimilate immigrants into Dutch society [19,23]. Troubled by high unemployment rate among visible minority immigrants, and by high profile incidents such the assassinations of Pim Fortyn in 2002 and Theo van Gough in $2004^{1}$, successive governments introduced increasingly

\footnotetext{
1 Pim Fortuyn was a populist right-wing politician who campaigned on an anti-immigration ticket. He was killed during the national election campaign in 2002. Documentary filmmaker Theo Van Gough was murdered in 2004 after he made a controversial film about the treatment of women in Islam.
} 
strict citizenship tests to educate and normalize immigrants to Dutch culture, society, and values. For example, the 2003 Naturalization Test was replaced by the Integration Test in 2006, a compulsory citizenship test for immigrants applying for temporary residence permit. The test stresses, in addition to the knowledge of Dutch language, understanding of Dutch culture and its liberal secular values, including the ideas of gender equality, individual freedom and autonomy, and the right to self-determination [22].

Vesta [19] argues that the Dutch government's shift to integrationist approach to immigrants was a part of welfare state restructuring that put more emphasis on individual self-sufficiency. Others, however, perceive this as part of a much larger and pervasive European-wide political and cultural shift: an attempt to recalibrate "multicultural ontology" [5], or what Jeffery C. Alexander calls Fortress Europe's' attempt to redefine and reconstruct European civil sphere in the face of the rising threat of a global multicultural tsunami [24].

Indeed, similar shifts in multicultural policies can be observed in other EU countries, including France, Germany and Denmark. In France, public debate on the headscarf began in the early 1990s; after 2002, the debate took on a noticeably more political tone as mainstream political parties such as PRP and UMP began to actively campaign for a ban on headscarves in public space. Joan W. Scott maintains that the passing of the 2004 French law banning the headscarf and other religious symbols was as much a response by President Jacques Chirac's UMP party to the threat of the growing electoral strength of the far-right nationalist anti-immigrant party Front National, as it was a response to growing public anxiety about Muslims in the post-9/11 French society [25]. In Germany, public debates of 'ghettorization' and 'parallel societies' burgeoned in the early 2000s [26]. As in France, the shift in public debate led to the introduction of a ban on the headscarf in 2003 [27]. In Denmark, increasing anti-immigrant public sentiments led to the abolishment of some key NGOs supporting immigrants, including the Danish Centre for Human Rights, the Board of Ethnic Equality, and the Documentation and Advocacy Centre on Racial Discrimination ([28], p. 217). Muslim protests of the infamous Muhammad cartoons met with the anti-dialogue and 'zero tolerance' policy of the Danish government [28]. ${ }^{2}$

These changes in public and political debates of multiculturalism in Europe highlight a particular form of multicultural rejection. Unlike the issues of racism and social economic inequalities between visible minorities and the white (Anglo) majority that continue to dominate North American multicultural debates, European debates focus on resident Muslims and Muslim immigrants, and the fear of European social disintegration resulting from the 'multicultural indulgence' of earlier decades [5,24]. Jeffrey C. Alexander [24] points out:

Inside history's most radical experiment in supra-national and anti-ethnic democracy, the European Union (EU), there has emerged a molting fear that, particularly vis-à-vis Muslim immigration, the independent status of the European civil sphere has become vulnerable indeed. From this sense of endangerment has followed newly restrictive legal, administrative and political measures; the rise to popularity of extremist political parties; and episodes not merely of random violence against Muslims but organized murderous attacks against outspoken supporters of the multicultural expansion of European civil societies (p. 533).

2 Here, 'zero tolerance' means zero tolerance towards Muslim threats against cartoonist Kurt Westergaad. 


\section{Multiculturalism in Canada}

Canada is routinely cited as a world leader in multiculturalism, representing the peaceful coexistence of multiple ethnicities and regions [29]. Canadian multiculturalism is frequently understood in terms of three different yet related notions: a specific government policy of pluralism, a social reality of a culturally and demographically diverse society, and a political ideology advocating cultural pluralism [29,30]. Additionally, Augie Fleras [31] argues that multiculturalism functions through an ideology and as a set of practices. As an ideology, multiculturalism proffers an image of how Canadians should live and interact within a pluralistic society, valuing diversity and being tolerant, respectful and non-discriminatory. As a set of practices, Canadian multiculturalism claims to embody fairness and equity whether by individuals, groups or institutions [13].

We see a serious contradiction between what multiculturalism promises and what it actually delivers, and argue that this contradiction can be best understood by conceptualizing it as a lived experience. Kymlicka [13] has argued that to understand the meaning of multiculturalism, we need to look at what it does in practice, not just what it says. That is, how does it impact intergroup relations and access to important social institutions? Similarly, Wood and Gilbert [29] contend that cultural identities are often negotiated in public spaces, institutions and everyday interactions. Therefore, simply examining particular multicultural policies misses an important point about what multiculturalism means for individuals and how it functions as a social ideology and in daily reality. In this study, we consider how Canadian multiculturalism is practiced in different social locations to reflect on its dynamics.

\subsection{Critiques of Canadian Multiculturalism}

Will Kymlicka argues for the enduring success of multiculturalism in Canada [13,18]. He contends that immigrant groups in Canada integrate more quickly today than before the adoption of multiculturalism policy, and they integrate more effectively than in countries without such a policy [13]. For example, naturalization rates have increased since the adoption of multiculturalism. Compared to other western democracies, Canadian immigrants are more likely to become citizens and to participate in the political process [32]. Moreover, children of immigrants and minorities have better educational outcomes in Canada than in any other western democracy [13]. Similarly, Dib et al. [33] point out the lack of extreme isolation often seen in American ghettos, the rise of mixed marriages, and the mixed socioeconomic conditions of concentrated immigrant areas as indicators of the success of Canadian multiculturalism [33].

However, many believe that multiculturalism impedes immigrants' ability to integrate into mainstream society. For example, citing a growing number of ethnic enclaves in Canada, Jimenez [34] argues that multiculturalism results in ethnic segregation and separatism. Taking the idea of ethnic communities to the extreme, Fulford [12] declares that Canada has become a land of ghettos because of multiculturalism.

These arguments are by no means new. In the mid-1960s, John Porter feared a strong emphasis on ethnic differentiation might lead to the emergence of multiple and divergent identities that would impede the development of a singular Canadian civic culture and identity [35]. In 1994, Neil 
Bissoondath [36] popularized this argument, saying that multiculturalism had undermined Canadian identity and values, created divided loyalties, fostered ethnic separatism and prevented the integration of newcomers. In addition, Reitz and Bannerji [37] found that second-generation minorities express lower levels of belonging to Canada than their immigrant parents. Multiculturalism has come under fire recently for fostering the development of socially harmful and politically dangerous transnational ties. Canadian historian Granatstein [38] believes multiculturalism promotes unhealthy forms of politically orientated transnationalism that undermine Canadian unity, identity, and foreign policy. He maintains multiculturalism encourages immigrants to engage in issues of the motherland, develop dual political loyalties, and import 'old world' conflicts, thus compromising opportunities to develop a strong Canadian identity and a sense of allegiance to Canada. This type of argument has snowballed since 9/11.

\subsection{Pluralism vs. Power Politics}

Multiculturalism in Canada has been attacked by scholars for not adequately addressing issues of social justice that impact on immigrants groups. Bannerji notes that the very foundation of multiculturalism is problematic: "the core community synthesized into a national "we", is still a colonial European identity slightly reworked into a Canadian identity, which decides on the terms of multiculturalism the degree to which multicultural others should be tolerated or accommodated' ([14], p. 42). Arat-Koc [39] adds that multiculturalism is based on a fundamental inequality between those who 'tolerate' and those who are 'tolerated'. Similarly, Hage [16] stresses that both racists and multiculturalists believe they govern the nation and it is up to them who stays in or out of the nation. Razack [9] and Thobani [10] note that multicultural policies celebrate white tolerance of racialized others by erasing colonial white settlement, the historical displacement of First Nations communities and the mistreatment of early immigrant groups. Others point out that multiculturalism shifts attention away from social justice and racism by focusing exclusively on ethnic identity and cultural diversity [14,40,41] Not surprisingly, Haque [17] concludes that multiculturalism is not a plurality in which all cultures are equally valued but premised on the privilege of western liberal cultures to which all other cultures are subordinated.

By grounding our analysis in the lived experience of multiculturalism, we show how Canadian Muslims' experiences reflect the various debates. Does multiculturalism ensure equality and the respect for diversity, as advocated by Kymlica? Has multiculturalism prohibited Canadian Muslims from developing a strong sense of national identity, as claimed by academics such as Bissoondath and Granastein? Or does multiculturalism leave Canadian Muslims vulnerable to discrimination by placing them in a subordinate position, as often suggested by those that study power politics?

\section{Research Methods}

We conducted in-depth interviews with 24 Muslim men and 26 Muslim women between the ages of 18 and 31. In-depth interviews are useful for studying the perspectives and thoughts of marginalized groups, as they allow the discussion and dissemination of their stories [42]. The interviews took place between 2005 and 2008, allowing us to learn about the experiences of 
Muslims in the four to seven years following $9 / 11 .^{3}$ The interview participants were guaranteed anonymity and given pseudonyms. The interviews were tape-recorded, transcribed, coded thematically, and analyzed using the N-VIVO qualitative analysis software program, which allows ideas and themes to be linked.

All participants identified themselves as Muslims. With the exception of one, who converted to Islam, all were born into Muslim families. The vast majority are second-generation Canadians. Eighty-two percent (41/50) are Canadian citizens; 40 percent (20/50) were born in Canada, 42 percent (21/50) were naturalized, and the rest were not Canadian citizens at the time of the interview and had lived in Canada for less than five years. While 30 participants were born outside of Canada, the majority had lived in Canada for many years. Interviews were conducted in Vancouver and Toronto, two metropolitan areas hosting 70 percent of the Muslim population in Canada [43].

We relied on personal networks to find interview participants. We directly approached some young Canadian Muslims. We initially contacted Muslim student organizations at the University of Toronto and at Simon Fraser University. To avoid over-sampling Muslim student organizations, we contacted other university organizations as well. At the end of each interview, we relied on snowball sampling and asked the participants if they knew of anyone else we could interview. However, we restricted the number of referrals from each interviewee to avoid over-sampling from a specific group.

During young adulthood, people explore a range of choices and begin to make commitments to interpersonal relationships, work, career, and ideology [44]. Therefore, we focused on Muslims in their young adulthood as they are in an important stage of identity formation and may have been more impacted by multiculturalism. We also focused on young Canadian Muslims because of the concern about second-generation visible minorities having lower sense of attachment to Canadian society as suggested by Reitz and Bannerji's [37] study. We wanted to see whether this also applies to Canadian Muslims.

All participants are well educated. At the time of the study, all had completed a post-secondary degree or were pursuing one. This is representative of young Muslim population in Canada, as the vast majority have some post-secondary education [45]. The sample also reflects the diversity of Islam. The participants come from India, Pakistan, Fiji, the West Indies, Libya, Bangladesh, Egypt, Saudi Arabia, and East Africa, they belong to Ismaili, Shia and Sunni, and they speak different languages. Even though many do not wear religious symbols, 12 women wear the hijab. With the exception of one who is half German and half Pakistani, all are visibly non-white. Diversity in the sample is important; findings are less likely to focus on experiences specific to a certain Muslim religious tradition or a particular ethnic or linguistic group.

This study does not claim to represent all young Muslims in Canada. Since this is not a randomly chosen sample, it cannot be generalized to the wider population with any degree of statistical confidence. Rather, it is designed to take an in-depth look at the experiences and interpretations of as wide a range of young Canadian Muslims as possible. Since our goal is not to evaluate the

3 Comments may well have been different before 9/11. A before and after comparison would be interesting, perhaps with an older study group. 
honesty and accuracy of their responses, we take the accounts at face value. That said, we look for contradictions in their stories and for explanations of what they say to avoid inaccuracies.

\section{Canadian Muslim Experiences}

Thirty out of our 50 interviewees (60 percent) claimed to have experienced overt forms of discrimination related to being Muslim since 9/11. Forty-one ( 82 percent) also have families or friends who have faced such discrimination. The discrimination directed at these young Muslims varied from everyday encounters with individual white Canadians where they were verbally and physically harassed to more systematic cases of racism such as employment discrimination and racial profiling at airports and borders.

\subsection{Discrimination by Bystanders}

Many of our interviewees told us that they were stigmatized because of their religious choices. For example, Haleema, a 19-year-old woman who immigrated to Canada at the age of eight from Jamaica, says she often gets racist and patronizing comments because she wears the hijab:

Sometimes people make comments: 'You don't have to go around hiding your beauty' or 'you don't have to go around trying to be so modest'. People say, 'Oh by the way you guys are very beautiful. You don't have to wear the hijab, and you don't have to be hiding your looks. You know this is Canada. You're free to do whatever you please. You don't have to wear that'.

Though mundane, these interactions signify pervasive inequalities and highlight the sense of entitlement felt by some white Canadians to question Muslim Canadians' religious practices and to pressure them to assimilate. The hijab is increasingly associated with militancy extremism, oppression of women, and anti-western sentiment post 9/11 [46], all of which feed into intolerance and/or patronizing attitudes towards Muslim practices. Many of our participants also recall being insulted or yelled at, and a few have had things thrown at them. Aatifa, a hijab-wearing, 24-year-old woman born in Saudia Arabia who immigrated to Canada at the age of 13, was spat upon:

Once I was on the subway and this white lady spit on me. First she just started screaming obscenities and saying how 'it was my people who did this', 'I was a terrorist' and 'that I need to get out of her country.' And then she spit at me. But I just kept quiet the entire time. I thought if I said something, I might provoke that person. And I wanted to show that we are not all the violent type.

Perry [47] notes hate crimes are often 'message crimes' that emit a distinct warning to all members of the victim's community: step out of line, cross invisible lines, and you too could be lying on the ground, beaten and bloodied ([47], p. 125). Since racialized violence is a way of asserting power, the racial violence directed at Muslim Canadians signifies deep inequalities. These actions thus inform Muslim communities that Islamic practises are not welcome.

As Wood and Gilbert remind us, 'public space is a space of presence, recognition, participation, and citizenship - it is the means by which difference is negotiated, affirmed or contested' ([29], p. 686). Public spaces, especially public transit, test the relationships between members of society and reveal the gaps between every day practises and the rhetoric of multiculturalism. The subway is a site of real public cultural contestation for Haleema: 
One day I was leaving Islington subway station and there was a guy walking by us and I could have sworn he mumbled terrorist. And I was like 'Did you just call us Terrorists'? I asked him because I was taken aback and I wanted to know if he had said it because he had mumbled it. And he goes 'yeah you are a terrorist'. I was like this sounds crazy so I just walked away.

To avoid facing harassment some, like Amineh, a Canadian-born, hijab-wearing, 23-year-old woman of Libyan descent, simply stopped using public transit:

I stopped taking public transit because I started getting harassed a lot...People would just do things to me. Like on the sky train I had these girls, teenage girls, blow condoms and start hitting me with them. There was such a huge group of them that I was worried about my safety. So I got off at the next stop and switched trains. And no one else on that sky train said anything or did anything. After that I stopped taking the public transportation because I do not feel safe or secure on public transit.

Amineh's experience illustrates the extent of the post 9/11 humiliation of Muslims. In this case, the silence of others during acts of discrimination works to condone the harassment. Others have found little support from authorities such as the police. A 31-year-old Egyptian man who came to Canada a year ago as an international student, claims that when his wife was verbally harassed and pushed on the street by a stranger in Toronto, the police did not show up for hours. Hate motivated violence commonly strives in an enabling environment [11]. Perry writes that 'racial violence is explicitly condoned when police fail to investigate or lay charges when victims report assaults motivated by racial violence' ([47], p. 129). In effect, law enforcement agents validate those who commit the crimes and reinforce discrimination by failing to respond seriously or in a timely manner.

The discrimination directed at Muslim Canadians not only involves verbal and physical abuse but can take the form of insensitive comments. For instance, Leela, a non-hijab wearing, 20-year-old woman born in Toronto to an East African family and Salim, a 25-year-old man, who came to Canada 11 years ago from Saudia Arabia, mention the following:

Leela: Sometimes when I meet someone new and they start asking you 'Oh where are you from? And what's your religion?' I get a bad reaction when I say 'I am Muslim'. Sometimes people will be like 'Oh, so that means you are a terrorist'. And I'd be like, 'What's wrong with you? No that does not make me a terrorist.'

Salim: When I was living in residence in university, I would have other students come up to me and make the stupidest comments. People would make comments around me like, 'How can Muslims do that' or 'How can Islam be a religion that allows something like that'. I even had a student actually come up to me and say 'What are you planning'? It took me awhile to respond to that and my response was 'I have nothing to do with any of this. I don't support it. I have nothing to be planning for.'

Clearly, being Muslim is often considered synonymous with being a terrorist. Muslims are seen as a homogenous group and are held accountable for the action of a few; as a result, they face comments that stigmatize their religious identities and rob them of their individuality. 


\subsection{Discrimination in the Labor Market and at Border Crossings}

Many of our participants discussed difficulties finding work because of employer discrimination against Muslim. This is especially a concern for Muslim women who wear the hijab, as Aisha says:

I think it was in 2002 when I was looking for a summer job and I had no luck. I did not know if it was because of me wearing the hijab or me being a Muslim or is just not me being lucky. I applied to several supermarkets and retail stories and that kind of places. And I remember the situation, my sister does not wear the hijab and there was a job opening at a store. I went there with my application and I asked where I could drop off and they said they had already hired someone. My sister knew someone that worked there and knew that they still had an opening. So my sister that does not wear the hijab went there and they actually took the application from her.

Hostility directed at the hijab can have serious economic consequences for Muslim women; not only does it compromise their religious freedom as discussed previously, but it limits their opportunities to find work, jeopardizing their livelihood and career prospects.

However, men also worry about finding work. Dawoud, a 25-year-old who was born in Saudia Arabia and came to Canada as a young child, recalls having difficulty finding a co-op work term, but suddenly 'began getting more interviews and job offers' after he deleted information about his involvement with Muslim organizations from his resume. Some potential employers pressure Canadian Muslims to abandon their religious customs. For example Umar, a 22-year-old Indian-Canadian with a long beard mentions that once at a job interview he was told by a potential employer to shave his beard if he wanted to work for their company. According to our interviewees, the labor market is a racialized space where they face blocked access and pressures to assimilate.

Canadian Muslims also have problems at airports and border crossings. While travelling abroad is a major headache, the extensive searching they experience within Canada is perhaps even more troubling. Several participants note problems associated with re-entering Canada. Zaahir, a 22-year-old Saudi-Canadian male, says:

Coming back to Canada has always been a problem. People would see that I am born in Saudi Arabia, that I am a Muslim, my family is all Muslim, so based on that they spend a lot of time going through our belongings or doing security checks. The reason why I see it as unfair is that we have been Canadians for 18 years without a blemish or any bad records.

Many of our participants feel that state surveillance practices at borders target them as potential threats to Canada - not as citizens. Although they have legal citizenship in Canada, they fear their rights can be revoked, especially when they are treated as if they do not belong in Canada.

What do these experiences tell us about multiculturalism in Canada? It is often claimed that the intent of multiculturalism is to ensure that minorities are treated equally by and within the larger society [13]. The experiences of the Canadian Muslims in our study do not reflect this claim; instead, they support the assertion that the multicultural model in Canada does not equally value all groups $[9,14,15,17,40]$. Instead of showing respect for diversity, in Canada (and other western nations), Muslim cultural practices are considered inferior and inappropriate. Cultural racism, wherein mainstream society is considered culturally appropriate and racialized groups are imagined to be culturally incompatible [48], prevails in Canada. Furthermore, because multiculturalism 
posits Anglo-Canadian culture as the core culture [14], white Canadians often feel entitled to question the practices of Canadian Muslims or to banish them from public spaces. Finally, the discrimination Muslim Canadians face in social institutions such as the labor market reveals that multiculturalism does not ensure a meaningful redistribution of power, resources, and opportunity.

\section{Maintaining a Dual Canadian and Muslim Identity}

Although most of the Canadian Muslim youths we interviewed frequently experience harassment and discrimination because of their Muslim identities, we also found that many continue to assert a strong Canadian identity, often using the rubric and ideology of multiculturalism.

Although few participants (13 out of 50) recall feeling less attachment to their Canadian identity after 9/11, the majority do not. In fact, 27 claim they have a strong Canadian identity, while 10 have developed an even stronger sense of being Canadian, despite discrimination. For example, Aneesha, a hijab-wearing, Pakistan-born 20-year-old woman who came to Canada as a young child, claims that 9/11 affirmed both her Canadian and Muslim identities:

The aftermath of 9/11 did not change how I saw myself as a Canadian. I think it changed how I saw myself as a Muslim [by affirming my Muslim identity], but not as Canadian. I've always seen myself as a Canadian. Like, I've been to the Canadian public school system since I was in kindergarten...Like, I don't like to keep myself within a certain area. I like to help out in different ways. I'm Canadian.

Other interviewees agree with Aneesha. These findings correspond to results from the 2002 Ethnic Diversity Survey [49], which found that many racial minorities continue to express warmth towards Canada despite economic inequities.

Political and international policies can affect the way Muslims relate to Canadian society. Several participants claimed to have developed a stronger sense of being Canadians after 9/11 because of Canada's global image as a peacekeeping nation and because of the perception that Canada is more tolerant of Muslim communities than other western countries. Asima, a Canadian-born 23-year-old woman of Indian-East African background, is one of these:

I think I became the happiest person in the world to be a Canadian. I mean we did not enter the war in

Iraq. We did not support America. We are a country of peace, and to be associated with a country like that it is amazing. The kind of treatment you get by having Canadian citizenship is amazing. Just the whole thing Canada stands for I was proud of. I was extremely proud to be Canadian and was proud of the way we handled the whole situation.

The discrepancy between the young Canadian Muslims' experiences of discrimination and their strong sense of Canadian identity may be attributed to the ideology of multiculturalism. It appears that for many of these young Canadian Muslims, multicultural policies provide what Breton [50] refers to as 'symbolic statements' that help them carve out a space within Canadian society. Our study suggests that the ideology of multiculturalism plays a huge role in how young Canadian Muslims place themselves in Canadian society. They describe a Canadian as someone who is 'tolerant', 'open to living in a multicultural society', 'welcoming' and having 'respect and appreciation for other cultures'. Thus, they envision being Canadian to mean being a part of a society that is inclusive of many cultures and groups, a sentiment officially advocated by 
multicultural policies since the 1970s. For instance, Sanya a 25-year-old woman born in Canada to an Indian-East African family, says the following:

I'm very happy to be Canadian. I think it's really a great society that it's multicultural; a lot of people from different backgrounds live here and are tolerant of each other. I know its cliché, but I'm proud to be Canadian because I just think that, you know, this country is more culturally tolerant than any other country in the world. Even though you're part of a visible minority group, you're still Canadian. You're still embraced into the Canadian culture. So you feel like everybody can be Canadian. I feel like it's sort of very welcoming, and that we try to respect and appreciate all cultures.

For our interviewees, multiculturalism is a crucial component of Canadian identity, inspiring them to hold onto to their Canadian identity despite living in a hostile environment. They believe that multiculturalism helps reduce racism by promoting cultural diversity and tolerance. Umar, a 22-year-old man, who was born in India and came to Canada four years ago, says: 'Multiculturalism encourages dialogue across cultures and ethnicities so it helps to deal with racial issues'. Moreover, many feel that multiculturalism has directly benefited Muslim communities in Canada. Yaman, a 25-year-old man, who was born in Canada and comes from an Indian background, mentions:

I think multiculturalism has helped a lot of communities in Canada, Muslim communities and others. I think it has helped me because without Toronto pushing for that in a lot different areas, I think it is possible that I would have been discriminated against more so. Yes, I think it has helped a lot.

Relying on the ideology of multiculturalism, young Canadian Muslims define the discrimination they encounter as being as anti-Canadian. Umar, a 25-year-old man who was born in Canada and who comes from an Indian background says:

They pushed me and called me 'terrorist' and told me to 'go home', so I got a little upset about that because I am in a university that teaches tolerance, acceptance, living in a multicultural Canadian society and the behavior they had towards me was the opposite of what that the university and society teaches.

Similarly, Zeba, a hijab-wearing 22-year-old female born in Canada but with an Indian background, resists discrimination by asserting her Canadian identity:

I don't like it. I mean I am Canadian. I'm born here and raised here. Just because I'm not a certain skin color does not necessarily mean I'm not Canadian. When people say 'I am not Canadian,' I become all rigid and tight inside. I'm member of society as anybody else.

Canada's national identity has historically been defined as 'white' [9,10,14], and as a result, Muslim Canadians fight to be recognized as Canadian despite holding Canadian citizenship. Through this resistance, they challenge the assertion that they do not belong in Canada.

However, as noted above, our participants retain a dual identity: they may be proud Canadians but they are also proud Muslims. Zeba says:

They ask me, 'So do you feel you're Muslim or do you feel you're more Canadian?' I've had people ask me this, and they think you can't be both, that somehow you have to pick one. And I think that's ridiculous, especially in a multicultural society to be asking something like that. I don't think there is a tension between the two. I think outsiders feel there's a tension, but I don't personally feel that there is a tension. 
Our participants insist on maintaining their Canadian identities but they strongly assert their religious identities in the post 9/11 era. Fifteen participants indicate that their Muslim identity was a focal part of their identity before $9 / 11$ and has remained so. Thirty-four say they have come to identify themselves more strongly as Muslims and feel a deeper connection to their faith in reaction to public reactions towards Muslims after $9 / 11$. A total of 49 out of 50 participants maintain a strong Muslim identity or have affirmed their Muslim identity since 9/11. Radi, a 25-year-old Canadian-born man with a Pakistani background, comments:

After 9/11, I was more proud to be recognized as a Muslim than before. When I would be with Muslim sisters who would wear the headscarf, I would want to be recognized as a Muslim compared to anything else. I wanted people to know that I was not going to be drawn away from the faith. I wanted people to know that the true Islam is not what happened with 9/11.

Despite seeing their religion associated with terrorism and under pressure to abandon their religious customs, these young Canadian Muslims fight back. They feel that they have every right to follow their religion and to assert their Muslim identity.

Overall, our study shows that many young Canadian Muslims continue to hold a strong dual identity despite facing discrimination in Canadian society. They do so by adopting and exploiting the ideology of multiculturalism. Our findings show that despite the many problems of multiculturalism, racialized groups may use its ideology as a resource to resist discrimination and to ground their identities. Our findings are similar to Matt James [51] who asserts that multiculturalism has historically served as a tool for excluded and oppressed people to form a civic voice. Of course, our interviewees are well educated and therefore more knowledgeable about their rights and better able to articulate those rights than those who do not have higher education.

\section{Conclusions}

In recent years, multiculturalism has been declared a failure on the world stage. It has been criticized for fostering ethnic separatism and failing to provide a common sense of national identity in western nations. Many even fear that multiculturalism may encourage terrorism in western nations. Our study, however, shows little evidence of such multicultural dissention in Canada —at least among our sample of young Muslims. Rather, it appears that many retain a strong sense of Canadian identity in the face of discrimination by exploiting the ideology of multiculturalism.

In light of these findings, how are we to make sense of the discourse surrounding the 'failure' of multiculturalism, which often uses Muslims as the prime case in point? Our findings lead us to argue that this discourse is, in fact, a racialized one. Since 9/11, the idea that Islam is innately and historically at odds with western values and principles has gained momentum. This sentiment has been popularized by authors such as Huntington [52] through the idea of the 'clash of civilizations', and Caldwell [53]. In his more recent work, Huntington [54] continues to label Muslims as an indigestible minority in the western world and casts Muslims outside the realm of western civilization. In a similar tone, Caldwell disparages the possibility of Muslims truly assimilating into European societies, pointing out that '[i]t is deeply held beliefs, not skin color, that present the main challenge. Europe's predicament involves population decline, aging, immigration, and the steady implantation of a foreign religion and culture in city after city' 
(p. 327). Since 9/11, this narrative of cultural clash has gained legitimacy among politicians, policy advisors and academics, and has taken center stage in debates of multiculturalism. In the recent cultural clash narrative, religion takes the place of race as the chief hindrance to modern society. Accordingly, whereas racism has been diminished by modernity and globalization, it is assumed that the inflexible nature of certain religions makes multicultural coexistence difficult.

Our research on Canadian Muslims illustrates that being Canadian and Muslim is not mutually exclusive, thereby challenging the 'clash of civilizations' framework. Other studies on British Muslims and American Muslims have reached similar conclusions. For example, Kibria [55] finds that despite the popular rhetoric that young Muslims in Britain reject their 'Britishness', many consider being 'British' as one of the most important aspects of their identities, one that coexists with their Muslim identities. Sirin and Fine [56] find that American Muslims value both their American and Muslim identities and utilize them simultaneously. These studies, along with ours, refute the idea that Muslim identities and western identities are irreconcilable.

The experiences of Canadian Muslims also reveal the inherent tensions and contradictions within multiculturalism. To be sure, many young Canadian Muslims live daily with contradictions of a national rhetoric that expounds of the multicultural citizenship rights on the one hand, and the reality of racial and ethnic discriminations at workplace, institutions, and public spaces on the other. The intensity of harassment and discriminations experienced by these Canadian Muslims should suggest that multiculturalism in Canada is failing them. However, what does it really mean for multiculturalism to 'fail'? If multiculturalism is to allow groups to maintain their cultural or religious identities while simultaneously adopting a western one, the Canadian Muslim case shows that it is not 'failing'; on the contrary, our interviewees maintain a dual Muslim and Canadian identity. Moreover, they maintain their dual Canadian Muslim identity by exploiting the ideology of multiculturalism in the face of discrimination. However, if the ultimate goal of multiculturalism is assimilation to the dominant culture, then perhaps it is 'failing', as Canadian Muslims do resist pressures of assimilation and instead work hard to retain their Muslim identities.

Mackey [15] reminds us that multiculturalism in Canada has been based on the management and controlling of difference-multicultures are fine as long as they are properly managed and remain loyal to the western project of nation building. Similarly, Ahmed [57] conveys that multiculturalism is often a contradictory process which distinguishes between those differences that it is willing to tolerate and those considered dangerous to even the most heterogeneous nations. In the post 9/11 era, Islam is seen as the biggest threat to western nations, and Muslim cultures and practices are no longer welcomed. The experiences of our interviewees make this abundantly clear. If any affiliation with Islam is perceived as a sign of disloyalty to the western world, then the refusal of Muslims to assimilate is most certainly seen as a 'failure' of multiculturalism. 


\section{Conflicts of Interest}

The authors declare no conflict of interest.

\section{References}

1. BBC. "State multiculturalism has failed, says David Cameron." 5 February 2011. http://www.bbc.co.uk/news/uk-politics-12371994.

2. Burns, John. "Cameron Criticizes 'Multiculturalism' in Britain." The New York Times, 5 February 2011. http://www.nytimes.com/2011/02/06/world/europe/06britain.html.

3. Brubaker, Rogers. "The return of assimilation? Changing perspectives on immigration and its sequels in France, Germany, and the United States.” Ethnic and Racial Studies 24 (2001): 531-48.

4. Grillo, Ralph D "Cultural essentialism and cultural anxiety." Anthropological Theory 3 (2003): 157-73.

5. Lentin, Alana, and Gavin Titley. “The 'Crisis of Multiculturalism' in Europe: Mediated miranets, intolerable subjects.” European Journal of Cultural Studies 15 (2012): 123-38.

6. Banting, Keith. "Is there a progressive's dilemma in Canada? Immigration, multiculturalism and the welfare state." Canadian Journal of Political Science 43 (2010): 797-820.

7. Helly, Denise "Are Muslims discriminated against in Canada since September 2001?" Canadian Ethnic Studies 36 (2004): 24-48.

8. Nagra, Baljit. "Our faith was also high jacked by those people: Reclaiming Muslim identity in the post 9/11 Era." Journal of Ethnic and Migration Studies 37 (2011): 425-41.

9. Razack, Sherene. "Imperilled muslim women, dangerous muslim men and civilized europeans: Legal and social responses to forced marriages." Feminist Legal Studies 12 (2004): 129-74.

10. Thobani, Sunera. Exalted Subjects: Studies in the Making of Race and Nation in Canada. Toronto: University of Toronto Press, 2007.

11. Poynting, Scott and Perry, Barbara. "Climates of hate: Media and state inspired victimisation of muslims in Canada and Australia since 9/11." Current Issues in Criminal Justice 1 (2007): $151-71$.

12. Fulford, Robert. "How we became a land of ghettos." National Post, 12 June 2006, A19. http://www.canada.com/nationalpost/news/issuesideas/story.html?id=0d7e614b-786b-4aae9535-2c588ca13a1e.

13. Kymlica, Will. "Testing the liberal multiculturalist hypothesis: Normative theories and social science evidence." Canadian Journal of Political Science 43 (2010): 257-71.

14. Bannerji, Himani. The Dark Side of the Nation: Essays on Multiculturalism, Nationalism and Gender. Toronto: Canadian Scholars Press, 2000.

15. Mackey, Eva. The House of Difference: Cultural Politics and National Identity in Canada. New York: Routledge, 1999.

16. Ghassan, Hage. White Nation: Fantasies of White Supremacy in a Multicultural Society. Australia: Pluto Press Australia, 1998.

17. Haque, Eve. Multiculturalism within a Bilingual Framework: Language, Race, and Belonging in Canada. Toronto: University of Toronto Press, 2012. 
18. Banting, Keith, and Will Kymlicka. "Canadian multiculturalism: Global anxieties and local debates." British Journal of Canadian Studies 23 (2010): 43-71.

19. Vasta, Ellie. "From ethnic minority to ethnic majority policy: Multiculturalism and the shift to the assimilation in the Netherlands." Ethnic and Racial Studies 30 (2007): 713-40.

20. Koopman, Rudd "Trade-Offs between equality and difference: Immigrant integration." Migration Studies 36 (2010), 1-26.

21. Hans Mahnig and Andreas Wimmer. "Country-specific or convergent? A typology of immigrant policies in Western Europe." Journal of International Migration and Integration 1 (2000): 177-204.

22. De Leeuw, Marc, and Sonja van Wichelen. "Civilizing migrants: Integration, culture and citizenship." European Journal of Cultural Studies 15 (2012): 195-210.

23. Engbersen, Godfried. "Spheres of Integration: Towards a Differentiated and Reflexive Ethnic Minority Policy." In Identity and Integration: Migrants in Western Europe. Edited by Rosemarie Sackmann, Bernhard Peters and Thomas Faist. Aldershot: Ashgate, 2003, pp. 59-76.

24. Alexander, Jeffrey C. "Struggle over the mode of incorporation: Backlash against multiculturalism in Europe." Ethnic and Racial Studies 36 (2013): 531-56.

25. Scott, Joan Wallach. The Politics of the Veil. Princeton, NJ: Princeton University Press, 2007.

26. Stehle, Maria. "White ghettos: The 'crisis of multiculturalism' in post-unification Germany." European Journal of Cultural Studies 15 (2012): 167-81.

27. Sauer, Brigit. "Headscarf regimes in Europe: Diversity policies at the intersection of gender, culture and religion." Comparative European Politics 7 (2009): 75-94.

28. Hervik, Peter. "Ending tolerance as a solution to incompatibility: The Danish 'crisis of multiculturalism.” European Journal of Cultural Studies 15 (2012): 211-25.

29. Wood, Patricia, and Gilbert, Liette. "Multiculturalism in Canada: Accidental discourse, alternate vision, urban practice." International Journal of Urban and Regional Research 29 (2005): 679-91.

30. Kallen, Evelyn. "Multiculturalism: Ideology, policy and reality." Journal of Canadian Studies 17 (1982): 151-63.

31. Fleras, Augie. The Politics of Multiculturalism: Multicultural Governance in Comparative Perspective. Toronto: Palgrave Macmillan, 2009.

32. Bloemraad, Irene. Becoming a Citizen: Incorporating Immigrants and Refugees in the United States and Canada. Berkeley: University of California Press, 2006.

33. Dib, Kamal, Donaldson, Ian, and Turcotte, Brittany. "Integration and identity in Canada: The importance of multicultural common spaces." Canadian Ethnic Studies Spring 40 (2008): $161-86$.

34. Jimenez, Marina. "Do ethnic enclaves impede integration?" Globe and Mail, 8 February 2007. http://www.theglobeandmail.com/news/national/do-ethnic-enclaves-impede-integration/ article1070403/?page $=$ all.

35. Porter, John. The Vertical Mosaic: An Analysis of Social Class and Power in Canada. Toronto: University of Toronto Press, 1965.

36. Bissoondath, Neil. Selling Illusions: The Cult of Multiculturalism in Canada. Toronto: Penguin Books, 1994. 
37. Reitz, Jeffrey, and Rupa Banerjee. "Racial Inequality, Social Cohesion and Policy Issues in Canada." In Belonging? Diversity, Recognition and Shared Citizenship in Canada. Edited by Keith Banting, Thomas J. Courchene and F. Leslie Seidle. Montreal, QC: Institute for Research on Public Policy, 2007.

38. Granatstein, Jack. Whose War is It? How Canada can survive in the Post 9/11 World. Toronto: Harper Collins, 2007.

39. Arat-Koc, Sadef. "The disciplinary boundaries of Canadian identity after September 11: Civilization identity, multiculturalism, and the challenge of anti-imperialist feminism." Social Justice 32 (2005): 32-49.

40. Joppke, Christian. "The retreat of multiculturalism in the liberal state: Theory and policy." British Journal of Sociology 55 (2004): 237-57.

41. Zine, Jasmine. "Stolen Youth: Lost Boys and Imperial Wars." In Omar Khadr: Oh Canada. Edited by Janice Williamson. Montreal \& Kingston: McGill-Queen's University Press, 2012, pp. 390-449.

42. Esterberg, Kristin. Qualitative Methods in Social Research. Boston: McGraw-Hill Press, 2002.

43. Statistics Canada. "Population by religion, by provinces and territories." 2001 Census. Available online: http://www.statscan.ca/ (accessed on 20 January 2011).

44. Mannheim, Karl. "The Sociological Problem of Generations." In Karl Mannheim: Essays on the Sociology of Knowledge. Edited by Paul Kecskemeti. London: Routledge, 1952, pp. 276-320.

45. Beyer, Peter. "Religious identity and educational attainment among recent immigrants to Canada: Gender, age and 2nd generation." Journal of International Migration and Integration 6 (2005): 177-99.

46. Haddad, Yvonne Yazbeck. "The post- 9/11 hijab as icon.” Sociology of Religion 68 (2007): 253-67.

47. Perry, Barbara. "Policing hate crime in a Multicultural society: Observations from Canada." International Journal of Law, Crime and Justice 38 (2010): 120-40.

48. Fredickson, George. Racism: A Short History. Princeton, NJ: Princeton University Press, 2002.

49. Statistics Canada. "2002 Ethnic Diversity Survey." Available Online: http://www23.statcan.gc.ca/imdb/p2SV.pl?Function=getDatafileData\&Item_Id=45768\&lang= en $\& d b=i m d b \& a d m=8 \& d i s=2$ (accessed on 15 February 2011).

50. Breton, Raymond. "Multiculturalism and Canadian nation-building." In the Politics of Gender, Ethnicity and Language in Canada. Edited by Alan C. Cairns and Cynthia Williams. Toronto: University of Toronto Press, 1986, pp. 27-66.

51. James, Matt. "Neoliberal Heritage Redress." In Reconciling Canada: Critical Perspectives on the Culture of Redress. Edited by Jennifer Henderson and Pauline Wakeham. Toronto: University of Toronto Press, forthcoming.

52. Huntington, S. “The clash of civilizations." Foreign Affairs 72 (1993): 22-49.

53. Caldwell, Christopher. Reflections on the Revolution in Europe. London: Penguin, 2009.

54. Huntington, Samuel. Who Are We: The Challenges to Americans National Identity. New York: Simon \& Schuster, 2004.

55. Kibra, Nahid. Young British Muslims: Identity, Culture, Politics and the Media. Edinburgh: Edinburgh University Press, 2010. 
56. Sirin, Selcuk, and Michelle Fine. Muslim American Youth: Understanding Hyphenated Identities through Multiple Methods. New York: New York University Press, 2008.

57. Ahmed, Sara. Strange Encounters: Embodied Others in Postcolonialty. London: Routledge, 2000. 


\title{
Promoting the Everyday: Pro-Sharia Advocacy and Public Relations in Ontario, Canada's "Sharia Debate"
}

\author{
Jennifer A. Selby
}

\begin{abstract}
Why, in the midst of public debates related to religion, are unrepresentative orthodox perspectives often positioned as illustrative of a religious tradition? How can more representative voices be encouraged? Political theorist Anne Phillips (2007) suggests that facilitating multi-voiced individual engagements effectively dismantles the monopolies of the most conservative that tend to privilege maleness. In this paper, with reference to the 2003-2005 faith-based arbitration debate in Ontario, Canada, I show how, in practice, Phillips' approach is unwieldy and does not work well in a sound-bite-necessitating culture. Instead, I argue that the "Sharia Debate" served as a catalyst for mainstream conservative Muslim groups in Ontario to develop public relations apparatuses that better facilitate the perspectives of everyday religious conservatives in the public sphere.
\end{abstract}

Reprinted from Religions. Cite as: Selby, J.A. "Promoting the Everyday: Pro-Sharia Advocacy and Public Relations in Ontario, Canada's "Sharia Debate"." Religions 4 (2013): 423-442.

\section{Introduction}

The 2003-2005 "Sharia Debate" in the province of Ontario, Canada offers a lens with which to consider why, in the absence of a clear interlocutor, an orthodox religious group was able to position itself as representative of mainstream Muslims who supported faith-based arbitration (FBA). ${ }^{1}$ This dominance is significant given the efforts made by an Ontario provincial government-appointed commissioner to facilitate broader more "everyday" responses. To reflect upon possible ways Western governments have sought to create democratized representative processes for minority Muslims that are not top-down state-created councils like the French Council of the Muslim Faith $^{2}$, I consider political theorist Anne Phillips' [5] suggestion that the reification of conservative

1 These kinds of debates and controversies receive a great deal of attention by journalists and academics. Yet, these requests are rare. Statham et al. ([1], p. 438) show in their analysis of group demands in the Netherlands, Britain and France from 1992-1998 that Muslim group requests for accommodation accounted for fewer than 3.5\% of all such appeals to the government. They are, in short, extremely minor.

2 In 2003 French Interior Minister Nicolas Sarkozy created the Conseil Français du Culte Musulman (CFCM or French Council of the Muslim Faith). Sarkozy envisioned a representative body for French Muslims who could be called upon when input was needed. Christians and Jews had similar representation in place. The government's involvement with the CFCM has drawn criticisms about state interference. These remarks were sharpest with the appointment of Dalil Boubakeur by Sarkozy as the first council president and with complaints that the organization 


\section{6}

religious men as spokespeople for communities in the UK could be rectified by facilitating heterogeneous theological positions. Moira Dustin and Anne Phillips' ([6], see also [7]) work on British policy formation underscores how, in a misguided attempt to be inclusive, when orthodox rather than liberal clerics are positioned as experts on religious practice in policy debates, too much power is granted to the more powerful members or gatekeepers in ways that overemphasize maleness. In Multiculturalism Without Culture ([5], p. 161), Phillips concludes that a better approach is to emphasize individuals and not groups to create a default multiplicity. In engaging Phillips' proposal I seek to reformulate Talal Asad's discussion of "how religion becomes public" ([8], p. 182) to ask which religion emerges predominantly, in this case which "Islam." I aim to show how, in practice, Phillips' suggestion is not effective in democratizing a variety of mainstream theological positions into public discourse. In practice, this approach is unwieldy and does not work well in contemporary soundbite-necessitating contexts.

In this paper, I propose three possible explanations as to why orthodox positions dominated the "Sharia Debate" - a lack of knowledge, competing voices, and poor public relations - and suggest that the debate was a benchmark in underscoring the importance of public relations for religiously conservative Muslim groups in Ontario. The Islamic Institute of Civil Justice's dominance made clear the importance of articulating arguments that are more palpable to a broader public. Thus, rather than assuming that Western governments should grant more voice to individuals to counter the power of orthodoxy as Phillips suggests, religious groups themselves must proactively develop public relations through websites and press releases to better translate their interests. Ideally this multi-voiced media-savvy engagement could reshape the so-called secular sphere to carve out space so that more religiously-motivated concerns could have a place in public debate, better reflecting a post-secular [9] and de-privatized public sphere [10].

Methodologically, I frame this critique with reference to fieldwork in 2008 and 2009 with pro- and anti-FBA members of advocacy groups in the Greater Toronto Area (GTA), where most of Canada's Muslims live, and examination of the 191-page government-mandated report and related press releases. I draw on statistical studies to cast the concerns of the so-called "everyday" Muslims I argue were excluded from the polarizing debate (on lived religion, see [11-15]). A 2008 Canadian Muslim Profile Survey suggests that $31 \%$ of self-defined Canadian Muslims attend mosque on a weekly basis ${ }^{3}$, yet other data show that no matter their level of practice, more than $90 \%$ of Ontario Muslims seek to marry using a nikah or Islamic marriage contract. "Average" Muslims are thus not necessarily attending weekly congregational prayer but do engage with Sharia

does not adequately represent the diverse makeup of French Muslims (see [2], pp. 71-84; [3], pp. 24-25; [4], pp. 85-87). Seats on the CFCM are apportioned according to the physical square footage of individual mosques, a system that benefits groups with greater financial resources.

3 According to the Canadian Muslim Profile Survey conducted in 2008 by the Canadian Institute of Policy Studies, $37 \%$ of respondents went to the mosque more than twice a week, and $31 \%$ once a week. Some (15\%) of respondents attended the mosque only for special programs, and $2 \%$ of respondents never went to a mosque [16].

4 Julie Macfarlane's recent qualitative research with Muslims on Islamic divorce in Southern Ontario and in three American cities (Dearborn, Los Angeles, and Omaha) concludes that "the number of Muslim North Americans who marry using a nikah is far higher than those who regularly attend prayers or even consider themselves to be observant." Ninety-eight percent of the marriages in her study were contracted using a nikah ([17], p. 11; [18]). 
at their time of marriage (and of divorce, thus necessitating some engagement with an imam or religious leader to be granted a religious divorce; see [17]). Accessibility to and engagement with Islamically-informed family law therefore generally matters to this population. Studies in Australia and the UK map similar kinds of everyday engagements with Islamic law (see [19-21]).

\section{Context}

In late 2003, the Islamic Institute of Civil Justice (IICJ) held a press conference to announce they would begin offering arbitration services in private family disputes in accordance with Islamic law and the province of Ontario's 1991 Arbitration Act. A two-year international debate followed this announcement. The FBA debate sought to assess the suitability of religiously-based legally-binding private arbitration in matters of commercial and family law. Arbitration decisions that articulated religious language and reasoning became possible in Ontario following an amendment in 1991, motivated to alleviate backlog in the courts and to move toward more cost-effective privatization. Because a number of Western European countries fear similar requests of accommodation by non-Christian minorities, the debate unfolded with international attention. Public concern centred on the legitimacy of references to Islamic family law in binding decisions. This focus explains why "Sharia courts" erroneously became short-form for the controversy. ${ }^{5}$ As though Sharia were a uniform instrument, this popularly used phrase falsely raised the spectre of stoning women and capital punishment [22,23]. In addition, Julie Macfarlane's [17] research with Ontario imams shows that mediation, and not legally-binding arbitration, takes place primarily; and, most common are meetings in imams' offices or in family homes and not in courtroom settings. In other words, commonly-expressed fears were unfounded.

That a non-mainstream Islamically-conservative position dominated the debate is worth noting for, as I will show, a 191-page government commissioned report, "Dispute Resolution in Family Law: Protecting Choice, Promoting Inclusion" [24], effectively captured multiplicity among Muslim groups. To the credit of its appointed author, former attorney general Marion Boyd, akin to Phillips' proposal, the "Boyd Report" portrayed the sophisticated non-theological arguments advanced by some pro-FBA groups and concluded that this form of dispute resolution continue with some caveats. Yet, these positions did not translate into public discourse. Instead, one conservative religious group, the Islamic Institute of Civil Justice, promoted their own Darul-Qada ('Islamic Court of Justice') and monopolized the pro-side of the debate. My aim is not to question the outcome of the controversy-religiously-based family law arbitration was legally outlawed in Ontario with a 2006 amendment - but rather to ask how and why a falsely representative "pro-Sharia" position was embraced as normative in representations of the debate. Their position erroneously exaggerated the degree and depth of cultural disagreement.

At the same time, reliance on orthodoxic positions is understandable for a number of reasons. Firstly, audiences of the Ontario FBA debate (including many Muslims) likely held little knowledge of the parameters of the traditions of Islamic law, so that more extremist positions like the IICJ's went unquestioned. FBA was surprising to many Ontarians. Generally, the public was

5 This paper refers to both sharia, as Islamic law stipulated in the Qur'an and the Sunnah, and fiqh, as jurisprudence or the more practical application of these sometimes abstract notions. 
not aware that the Arbitration Act could be used to settle family law and inheritance disputes, or that if an arbitration award were made under the Act, it could be enforced by Canadian courts, no matter the religious tradition. Until 2003, it had taken place without public scrutiny; when Islamic law was referenced, concern heightened. In this way, a lack of knowledge alongside irrational fear of Islam (or Islamophobia) were factors in how the IICJ and their message monopolized public debate. Prior to this period, faith-based family law arbitration had taken place in Ontario for 14 years with no public fanfare, largely among Orthodox Jews but also among some Christian groups as well as Shi'ite Ismailis ([24], p. 56; the Boyd Report notes the Ismailis' "sophisticated and organized" arbitration model [24], p. 57).

Secondly, the tremendous ethnic and legal diversity among the Ontario Muslim community made centralizing religious authority in the community a challenge. Therefore, when the IICJ became the de facto spokespeople for FBA it was difficult to draw together a counter-narrative. Paul Bramadat ([25], p. 13) describes how Canadian Muslims constitute the most ethnically diverse group in Canada and they are similarly theologically diverse. ${ }^{6}$ Longer discussions on the malleability and construction of fiqh (Islamic jurisprudence) in minority populations did not have a necessary 'soundbite' quality to counter the IICJ. Even if, following the spirit of what Tariq Ramadan calls "the building of the Muslim personality in the West" ([22], p. 7; see also [31]), a number of imams in the GTA have worked together to contextualize Islamic law for a Canadian Muslim minority situation and develop a figh for minorities, positioning family law for all Muslims in Ontario at the moment of the debate was impossible. ${ }^{7}$ Compiling a 'fiqh for minorities' is a long-term project that could not be amassed within a few weeks, particularly given the provincial Muslim communities' diversity.

Thirdly, the pro-Sharia side's public relations errors gave it visibility. Its more extremist views on apostasy were simplistic and were therefore more readily taken up by opponents and through media statements. Indeed, seeking to locate stable theological positions - and not the complexities within which most religio-cultural interpretation takes place-meant that media outlets and the final government response by the provincial Premier accentuated a more facile monolithic religiously-conservative position.

I contend that exploring the IICJ's dominance in light of Phillips' contribution is worthy of examination because the dispute devolved into debates that highlighted fears of patriarchal religiosity that did not appropriately engage with a number of substantive issues. A more robust, reflective and useful debate could have taken place. As Anna Korteweg and I have argued

6 The Muslim population in Canada in 2001 was 36.7\% South Asian, 21.1\% Arab, 14.0\% West Asian, and 14.2\% were part of other minority groups (not including the small percentage of Chinese, Black, Filipino, Latin American, Korean, and Japanese Muslims; [26]). PEW's 2010 estimations suggest there were just under 1 million Muslims in Canada or $2.8 \%$ of the entire population [27] The most recent reliable data predict that by 2017, the Canadian Muslim population will be approximately 1.6 times the 2001 population of 579,645 (see [28,29]) and that by 2030 the population will be approximately 2.7 million, or $6.6 \%$ of the Canadian population [30].

7 The Canadian Council of Imams (CCI) was established in 1990 and is constituted by more than 40 members. The CCI meets monthly to discuss relevant elements that affect Muslims in Canada (see [32,33]). Their website notes that it "has become the principle [sic] liaison with Federal, Ontario Provincial and Toronto Municipal Governments." 
elsewhere [34], matters like unilateral talaq divorce $^{8}$ and the equal rights of all women in private arbitration no matter their faiths were never publicly debated ${ }^{9}$, in part because the more varied pro-faith-based arbitration (FBA) positions captured in the Boyd Report did not translate beyond the document into public discourse. Because the debate remained focused on murky fears of Islamic law, significant power issues in arbitration and patriarchal divorce proceedings were not formally debated and have remained unchanged.

Pro-FBA advocates were not aided by the IICJ's conservative head, former lawyer Syed Mumtaz Ali, whose initial public announcement spurred the debate. Ali had begun lobbying for these tribunals two decades earlier. ${ }^{10}$ The IICJ made a number of significant public relations gaffs through their publicly-accessible website and in interviews where Ali shared inaccurate claims. For example, Ali announced the opening of "sharia courts," a turn of phrase that gave a false sense of courtrooms where Muslims would be judged, when studies show that most Ontarian Muslims seek out counseling or assistance from imams, who take a mediative and not arbitral role ([17], p. 15, [37], p. 76). In addition to his invocation of "sharia courts," in seeking to inspire Muslims to use his services, Ali set out vitriolic theological claims that warned of apostasy: only "good Muslims" would use their services [39,40]. ${ }^{11}$ Ali referenced Qur'anic passages that described "infidels," rhetoric that served to alienate the Darul-Qada from mainstream Muslims ([42], p. 247) and non-Muslims. In sum, references to "sharia courts" and "good Muslims" did not quell fears that groups like the Darul-Qada sought to create a parallel legal justice system, which would weaken the rights of Muslim women and the functioning of the liberal democratic state ([34], p. 12). The IICJ's condemnatory language in their press releases and on their website gave the impression of a newfound coercive power overstepping the bounds of the Canadian legal system. Ali's characterization of "Sharia Courts" suggested that arbitration decisions are not subject to judicial oversight, a point that was quickly propagated in the community and with the media. Ironically, there is no evidence that the IICJ ever carried out formal religious arbitration ([37], p. 68).

Opposition to the IICJ's announcement to open "Sharia courts" emerged quickly among local and national secular and Muslim organizations. Two anti-faith-based arbitration groups led by women perceived as Muslim ${ }^{12}$ became most prominent: the "International Campaign Against Shari'a Court in Canada" and the government-funded Canadian Council of Muslim Women were sophisticated in their press releases, websites, and social media mobilization. Other secular Muslim

8 There are typically three forms of marriage dissolution outlined in mainstream Sunni jurisprudence: talaq, khul and faskh. In the first case, traditional Islamic juristic traditions accord unilateral extra-judicial divorce rights solely to men, grant women limited alimony ranging from three months to one year, and typically favour men in child custody and inheritance rights. Talaq divorce - or unilateral divorce by the husband - is the most common form of divorce among Canadian Muslims (see [35], pp. 33-34; [36], pp. 20-23).

9 In addition, many Ontario-based imams who act as mediators are being stretched thin by the familial counseling often demanded of them and are ill-equipped to respond to domestic abuse [17,37].

10 Ali was called to the Ontario Bar in 1962 and was the first lawyer to take his legal oath on the Qur'an rather than on the Bible [38]. Syed Mumtaz Ali passed away in 2009.

11 Here Ali uses polemical language like that critiqued by Mahmood Mamdani [41].

12 Homa Arjomand of the International Campaign against Sharia Court in Canada calls herself an "atheist Muslim" [43]. Alia Hogben of the CCMW claims to be a practicing Muslim. 
organizations like the Muslim Canadian Congress were also involved in critiquing FBA. ${ }^{13}$ Altogether eighty-seven groups came together to oppose the IICJ's announcement ([45], p. 257). Only nine organizations espoused FBA publicly, several with qualified support, like that from the Jewish Beth Dein. These groups include the Canadian Council on American-Islamic Relations $(\mathrm{CAIR}-\mathrm{CAN})^{14}$, the Islamic Society of North America Canada (ISNA), the Canadian Islamic Council (CIC) $)^{15}$, the Federation of Muslim Women and the Coalition of Muslim Organizations of Ontario (COMO), which represents over 30 Muslim organizations ([48], p. 108). While fewer in number, analysis of media coverage throughout the debate shows how the pro-FBA stance was underrepresented ([49], p. 441).

In response to growing concerns about Islamic law exacerbated by comments like these ones, Marion Boyd, a former Ontario Attorney General, was appointed by the provincial Attorney General and the Minister Responsible for Women's Issues to review the Arbitration Act and its impact on vulnerable peoples in the province. During the course of the review Boyd met with close to 50 groups ([24], p. 5). Six months later in December 2004, Boyd submitted her report that outlined concerns expressed during the debate and made 46 recommendations. The report gave qualified support for FBA for all faiths. Boyd concluded that to only bar Muslims from religiously-based arbitration constituted clear discrimination ([24], p. 73).

Following Boyd's qualified recommendation of the status quo, a number of pro-Sharia representatives like Faisal Kutty [50], legal representative for the Coalition of Muslim Organizations of Ontario (COMO), assumed the debate was over and that citizens could continue to choose to legally arbitrate family matters with a religious leader. Having participated in the exercise of the Boyd commission, and having seen their views reflected in the Report, groups like COMO excused themselves from the public eye. Following Boyd's recommendations, as Katherine Bullock, ISNA representative noted, "the eventual decision in 2005, to ban FBA for all, did not cross our minds - we could not imagine that the government would take away an accommodation that was already present in the law" ([51], p. 258).

However, following the publication of the Review, public debate continued. Boyd's reasoning to maintain FBA in Ontario fell on deaf ears as subsequent international protests at Canadian embassies against "Sharia Courts" in September 2005 referenced the stoning of women and human rights atrocities. With mounting international pressure, on 11 September 2005 (a Sunday not typically reserved for government press releases), then-provincial Premier Dalton McGuinty announced: "There will be no Shariah law in Ontario. There will be no religious arbitration in Ontario. There will be one law for all Ontarians" [52], thus barring FBA for all religious groups.

13 Internationally, these groups received support from the Progressive Muslim Union of North America and the grand mufti of Marseilles, Soheib Bencheikh. Nationally, these groups' critiques of FBA were bolstered by prominent politicians like Quebec MPP Fatima Houda-Pepin and the Ontario Women's Liberal Caucus [44].

14 The Ottawa-based non-for-profit Council on American-Islamic Relations Canada (CAIR-CAN) was founded in 2002 and has been active in a number of lobbying campaigns, including those surrounding the Maher Arar and Omar Khadr cases ([46], p. 203).

15 The CIC is based in Saskatoon, SK and was formally incorporated in 1998. It has been in the active in the media on the Israeli-Palestinian Conflict, a Human Rights complaint against Maclean's, and the Canadian Anti-Terrorism Act of 2001, among others [47]. 
An amendment in February 2006 (the Family Statute Law Amendment Act) legally ended faith-based arbitration in Ontario. However, social scientific research by Julie Macfarlane and Christopher Cutting demonstrates that, because arbitration was never widely used (informal mediation was far more common), very little has changed. Religion can inform an arbitrator's rulings so long as the texts of final rulings use the language of Canadian law and make no reference to religious principles $[17,50,53]$. With this background of the debate in mind, I now turn briefly to three factors that influenced the IICJ's monopoly of the debate: a lack of knowledge about what was being requested, competing authorities, and poor public relations.

\section{Islamophobia and Ignorance}

Islamophobic elements are evident in how the debate unfolded and may partially explain its derailment into now familiar patriarchal critiques of Islamic beliefs and practices. In these public debates, Islam was often positioned homogeneously as a patriarchal religious tradition that condones the cutting off of hands and the stoning of women [54-56]. These media accounts and press releases were not neutral. A number of pro-FBA Muslim spokespeople observed that paternalism and Islamophobia informed those who conducted media interviews. For instance, part-time ISNA Canada spokesperson Katherine Bullock noted that "the level of hatred has been frequently astonishing" [57] and recounts having experienced Orientalizing portrayals of the tradition in her encounters with the media ([51], pp. 262, 269). The IICJ's inaccurate call for "Sharia courts" gained a great deal of attention and authority because of a lack of knowledge about the parameters of Islamic family law and the kinds of mediation that were commonly taking place. This lack of knowledge extends within Ontario Muslims' communities, as well. Some of the so-called average Muslims I interviewed in 2008 similarly felt they could not speak up to counter this characterization, as they were not legal specialists.

\section{Dispersed Authority}

Dispersed religious authority had a significant impact on the seemingly highly-conservative pro-FBA lobby. In the first place, theological diversity in part explains why it took longer for the Coalition of Muslim Organizations of Ontario (COMO) to respond as a united group. A shared sense of the parameters of Islamic jurisprudence and arbitration processes did not coalesce in the midst of the debate, so that Muslims and non-Muslims were unable to engage with its potential positive implications. Part of this lack of representation relates to the traditions of Sunni Islam and its non-centralized authority structure that does not support a hierarchical clerical class that acts as a representative body. Federal and provincial governments have not established religious authoritative representatives following Protestant models, like the French government has mandated with the French Council of the Muslim Faith.

This lack of a unified theological position became apparent in how pro-FBA groups disagreed about the utility of referencing the term 'Sharia'. On the one hand, pro-FBA groups like ISNA Canada and the Islamic Institute of Toronto (IIT) suggested that over-usage of the term precluded a measured and qualified discussion of how fiqh-based arbitration could be developed and regulated. They preferred the more specific and contextual term fiqh or what Marion Boyd, aware of 
differences on the term, referred to more generally as 'Muslim principles.' On the other hand, the Canadian Islamic Congress (CIC) noted in a media communiqué that the term must be embraced, out of respect for its meaning and history:

Sharia is Arabic for Islamic Law and there is no need for Canadian Muslims to be apologetic. Those who oppose the use of the word Sharia, but say the tribunals will use 'Islamic principles' are contradicting themselves [...] We should not let those abusers rob us of a word that has a long and noble history [58].

This discord on language reflects a range of views. Despite having been organized for a few years, the COMO (the Coalition of Muslim Organizations of Ontario) formed their common unified response following the announcement to end FBA [24]. At that point it was too late to impact public opinion.

In the third place, this kind of public opinion campaign is not easy for groups often largely composed of volunteers. ISNA Canada representative Katherine Bullock described having had a number of work and familial responsibilities that made her often unavailable for the short turn-around time necessitated by the media ([51], p. 261). Her absence meant that at times more moderate pro-FBA voices were excluded.

These shortcomings in theological unity and public presence overshadowed the other Ontario-based pro-FBA Muslim groups' press releases' sophisticated arguments submitted for consideration by Marion Boyd. While I recognize the homogenizing and naturalizing forces in determining the "mainstream," I argue that these arguments sought to demonstrate how FBA could signal a Canadian multicultural ethic in light of the Charter of Rights and Freedoms; pointed to how FBA could save tax dollars in alleviating the overburdened public court system; claimed that structuring it more formally would allow for greater transparency; and argued that, counter to the main concern by anti-FBA groups, FBA offered better opportunities for the protection of women's rights in allowing for "indigenizing" opportunities. These kinds of arguments that move away from apostasy arguably would have had greater credibility and been more legible amidst the broader public narrative on the suitability of FBA in a supposedly secular country. Despite constant references in the Report to the country's secularity, Canada does not have a formal legal separation of religion and politics [59].

Firstly, in their press releases and submission to the Boyd Commission, the Islamic Society of North America Canada based their support for FBA primarily on liberal democratic grounds. They challenged the notion that judicial autonomy in the form of 'sharia-inspired tribunals' would lead to a fracturing of the secular state and stated that "a denial of this right to Sunni Muslims will be reckoned as discrimination and a singling out of a religious group in Ontario. This will be counter to Canada's Charter of Rights and Freedoms, which guarantees freedom of religion for all groups" [24]. The group drew on multicultural guarantees and political arguments regarding the possibilities for coexistence of religious law within a secular framework. CAIR-CAN framed its rationale similarly, stating that any form of Muslim dispute resolution would be "consistent with Canadian law and the Charter" ([60]; see also [61]; [24], p. 44). The Canadian Islamic Congress's (CIC) then-president went further to describe the end of FBA as a violation of the Charter.

Secondly, the head of the CIC appealed to practical considerations noting that such arbitration would "ease the backlog in the courts" and that "many judges prefer this" [62]. In other words, 
FBA saves taxpayers' money. This justification worked for former Premier Mike Harris whose then-conservative majority privatized a number of government programs as cost-saving measures in the 1990s.

Thirdly, a number of pro-FBA groups noted that mediation related to familial conflicts was already common, making arbitration a viable new option. Here pro-FBA advocates noted how many Ontarian Muslims feel that their interests and confidentiality are better protected by an imam, who also typically does not charge for his services, unlike a professional counselor, mediator or lawyer [17]. Following this argumentation, Riad Saloojee, a CAIR-CAN spokesperson, pointed out in a communiqué submitted to the Boyd Report that pragmatism should motivate policy makers to maintain the status quo related to FBA: "The reality is that on the ground, faith-based arbitration is already going on in an informal way," noted, so that "the best way is to regulate it and ensure it is transparent" [63]. Faisal Kutty, legal representative of COMO, moved from an argument of practicality to one of fairness and suggested that FBA for Ontarian Muslims reflected an opportunity to "indigenize" Islamic legal rulings so that they could be better regulated and supervised ([50], p.124). For Kutty, this process would allow judicial oversight into practices that would better reflect the beliefs of religious minorities while integrating them into the Canadian legal system. He referenced similar language to Saloojee, arguing that "formalizing the process will allow for greater transparency and accountability" [64], both of which would positively impact women.

On this note, contrary to the pejorative portrayal of pro-FBA groups like the CCMW whose public platform focused upon how Muslim family law perpetuates patriarchy ([24], p. 48; [65]), pro-FBA groups also reflected on Islam and gender politics, a point that did not translate well into the public debate. ISNA Canada's spokesperson, Katherine Bullock, proposed an equity model based upon gender complementarity to counter what she called the "Liberal-feminist version which says that if men and women are not treated in an identical manner, then women are being oppressed" [50]. Other pro-FBA advocates positioned Islam as pro-women and saw FBA as a way to convince culturally-patriarchal religiously-minded men of this fact. As cited in the Boyd Report, Mubin Shaikh of Toronto's Sunni Masjid El Noor ${ }^{16}$ noted:

when decision [sic] in favour of women are made against men who are ignorant of the rights of women afforded in Islam. The authority of the Tribunal will prevent a disputant from accusing it of ignoring their Islamic values - a claim frequently made against the secular system. Through this authority, the community will pressure the wrongdoer to conform to the norm and encourage him/her to cease their sinful behaviour ([24], p. 64).

Along these lines, in one of its public position papers, ISNA Canada argued that immigrant women would feel more "at home" with Muslim arbiters, who would also guarantee privacy and confidentiality in a way a "secular court" does not [24]. This concern about women's rights was the central issue for anti-FBA groups, a point that needed to be better addressed by groups who supported it. Despite nuanced written submissions for the Boyd commission by pro-FBA advocates

16 Formally since 1982 and informally prior to that, the Masjid El Noor has offered counselling, mediation and arbitration services carried out from a pastoral care point of view. Their mediation board consists of seven people, one of whom is an imam and the rest of whom are volunteers divided equally between men and women. The mosque provides translations in Gujurati and Urdu to those who need services in other languages ([24], p. 60). 
of the potential advantages FBA afforded to women, symbolic representations trumped these reflections. In the wake of the debate, Faisal Kutty, legal counsel for COMO, conceded that from a public perception perspective, the group should have strategically situated Muslim women as the leaders and spokespersons [50,66]. Because Muslim women are not equally represented in the institutional structures of Ontario communities, such as in mosques, schools, and community centers, this inclusion would have greatly aided public perception. The 'pro-Sharia' campaign thus did not respond effectively to the oppressed Muslim woman trope that emerged so prominently; there was little confidence that Sharia-based tribunals would be any more responsive to women's interests.

A unified and authoritative message that effectively and, following John Dewey's theory of communication [67], aesthetically and effectively conveyed the socio-political benefits of FBA for non-Muslims or non-religiously practicing Ontarians - including a reduction in public court costs and a potentially more robust multiculturalism - did not occur. In part, enunciation of the role of women might have been better assured by stronger public relations. These articulations matter because when policy discourses privilege orthodox positions like the IICJ's, they tend to accept sweeping characterizations of women's social comportment and rights [68-72].

\section{Orthodoxy and Public Relations}

Religious conservatism does not lead to uniformity in theological positions. Acknowledging the power dynamics laden in the homogenizing category of the "mainstream," religious studies scholars are well aware of the diversity of belief and practice in religious systems, including a range among the most orthodox. Nancy Davis and Robert Robinson's ([73], p. 243) quantitative overview of conservatism among Protestants in the US demonstrates that the religiously orthodox exhibit little consensus of opinion on specific issues and, as individuals, hold inconsistent views. Rajeev Bhargava [74] warns of intra- and interreligious domination, where certain branches within the same religious tradition are privileged by members, the public and by scholars. Overuse of a narrow understanding of orthodoxy is therefore problematic because, as I have described, it is not representative of contradictory everyday experiences of religious beliefs and practices among mainstream publics.

Facilitating these positions assumes that everyday individuals will want to share their opinions. These 'average' individuals have a right to indifference or a lack of knowledge on the application and interpretation of religious law. For instance, one of my female interlocutors interviewed regarding her experience of the FBA debate explained her frustration with herself for not becoming more involved. 'Asma' explained, 'I'm busy with my three young children. I think this is an important issue, but what can I do? And I don't know the Sharia. I can't go on talking about it when I don't know the hadith" [75]. Capturing Asma's position is central to unlocking the common concerns of Muslims in Ontario who were for FBA, but whose voices were absent from discussions. Asma's experience reflects how other individual pro-FBA voices existed, but were not captured by the public debate for a variety of reasons, including not being sensational enough for the media, who preferred a simplistic, reductive approach to the issues at hand.

In sum, with the exception of Phillips' [5] suggestion of emphasizing individuals in Western public policy matters rather than institutionalized groups, theory about which religion emerges through policy has not fully considered how orthodox positions take precedence [10]. Critiqued for 
how she characterizes Muslims primarily as "different, as not-wholly-Canadian, and perhaps as potential threats to 'real' Canadians" ([76], p. 350) and for too plainly pushing a multicultural ethos that masks inequalities [77], Marion Boyd's Report is nevertheless a good example of what Phillips describes. The Boyd Report successfully captured nuances related to arbitration and to Islamic law from a variety of Muslim perspectives. Even if the pro-FBA groups under examination engaged with the language, national culture and citizenship rituals necessary for full engagement in their consultation with Boyd ([1], p. 428), pro-FBA groups were unable to translate this into political action and public discourse. In part this disconnect was due to limited resources, to a media bias and to a lack of understanding in the community regarding the broader implications. Pro-FBA groups were not able to transmit their more sophisticated explanations in the mediatized debate that had too quickly latched to the IICJ. By way of conclusion, I suggest that policy engagement and media knowledge are keys to this end.

\section{Conclusions}

The Sharia Debate has become a benchmark for a number of Ontario Muslim groups who seek to better facilitate their positions in public debate. Public perception and relations are clearly important in shaping opinions and the course of debates like this one. The post-9/11 and 'Toronto $18^{17}$ environment casts suspicion on Islamic-informed engagement. In this climate, Ontario Muslim groups acknowledge the importance of promoting the positive engagements of their members. Macfarlane similarly notes that while post-9/11 Islamophobia negatively impacts the lives of women and men who are Muslims in Ontario, it also enforces a "commitment to greater openness and communication with non-Muslims" ([17], p. 7). Canadian Muslim organizations have, since the Sharia Debate, become more cognizant of the need for sophisticated public relations and political lobby. To make this point, I point to three examples in Ontario, the US and the UK that highlight differing ways these groups have shifted their strategies.

Firstly, a public policy and government course developed in the wake of the FBA debate at the Islamic Institute of Toronto specifically addressed the importance of knowing the system to engage government ([78], p. 362). This initiative reflects a newfound post-2005 proactive stance. The aim of these evening classes was focused on affording Muslim Canadians knowledge of the political system so that they would feel empowered about practical matters, like governmental structure and when advocacy could take place. In one May 2008 class, the Pakistani-born Canadian teacher outlined the hierarchies of municipal and provincial governments, the common ways in which policy and law are created, and when an informed citizen might best lobby his or her council member (town hall meetings are too late). This course clearly advocated religiously-informed lobby and was inspired by frustration felt by the instructor who worked in the provincial legislature. This kind of mobilization suggests that knowing the political system allows individuals to better engage with government so to translate their arguments, and exemplifies Jose Casanova's

17 The "Toronto 18" refers to eleven men and four youths arrested on 2 June 2006 (two others were arrested who were already serving prison terms, another was arrested two months later), accused of participating in plots to attack Parliament Hill among other locations. That these were the first arrests after the 9/11-related anti-terrorist legislation and that these threats to Canada were "homegrown" raised the spectre of radicalization. 
[10] now-classic argument of the deprivatization of religious perspectives in political lobby. This engagement does not wait to be called upon as consultants like with the Boyd Report but rather seeks to frame potential issues.

Secondly, in 2011-2012, the New York State-based Islamic Circle of North America (ICNA), which has 30 chapters in the US, launched a $\$ 3$ million public awareness campaign to destigmatize the term "sharia" among the American public. Its timing suggested that it emerged in part in response to the IICJ's public relations disaster. Its campaign focused on recent Sharia debates in the United States where 13 states are considering legislation to forbid "Sharia," with aims to dispel "the myths surrounding Shariah Law" and to communicate "the truth to the American public." They outlined these efforts as defending religious freedom and warding against Islamophobia [79]. Using Christian-based references to appeal to non-Muslim Americans they noted:

There is no one thing called Shariah. A variety of Muslim communities exist, and each understands Shariah in its own way. No official document, such as the Ten Commandments, encapsulates Shariah.

ICNA does not elaborate, however, as to more specific sources of authority and how figh would be determined. Their campaign is primarily focused on de-stigmatizing Islamic law.

Thirdly, Marta Bolognani and Paul Statham [80] point to how British Muslim organizations have formed alliances to more efficiently and effectively brand themselves. Based on qualitative interviews with British Muslim organizations, they note that Muslim community representatives recognize how the media shape perceptions. They cite an imam who argues that "stories about Muslims [are] restricted to a negative focus and limited to only a few oft-repeated clichéd cultural issues, usually on wearing a burqa or niqab, or claims about the treatment of women" ([80], p. 238). Bolognani and Statham report that their participants found that sensationalism meant that unrepresentative, even if camera-ready, individuals were more often selected for interviews; one example given of someone who had interviewed a great deal but who has few actual followers was Anjem Choudary, akin to the IICJ's former president, Syed Mumtaz Ali. They also cite a representative from the Bradford Council for Mosques who suggests how engagement with the media is necessary, and that "faith leaders generally are not very good at interacting with the media. There are many positive stories and many positive examples of work which should be shared widely. The media offers us the opportunity to do this" ([80], p. 239). Daniel Nilsson DeHanas and Zacharias Pieri [81] similarly show the significance for the Tablighi Jamaat of hiring a PR company to manage their image and website in the midst of the building of a 'mega-mosque' construction adjacent to the main 2012 Olympic site near London. Nilsson DeHanas and Pieri note that the mobilization of their website (now defunct) allowed them to promote a more modest mosque. Beforehand, the Tablighi Jamaat's web and PR absence "perpetuated their image as an isolated and secretive group" ([81], p. 809). Again, these apparatuses matter.

Returning to the Canadian context, the importance of this sophistication and proactive media portrayal has been solidified. After the April 2013 Boston Bombings when the Royal Canadian Mounted Police arrested two men suspected of a railway terror plot in Toronto [82], a number of Muslim organizations like CAIR-CAN very clearly and intentionally dis-associated themselves from these actions. This collaboration of Muslim groups with police reflects years of negotiation and trust-building undertaken with the Royal Canadian Mounted Police. Toronto Imam Yusuf Badat 
made evident to $\mathrm{CBC}$ Radio that Muslim leaders are taking steps to help prevent radicalization. Badat concluded:

We tell them [members], 'be part of the broader mainstream community. Get involved. Be part of the civic engagement. Learn Islam from the right sources, rather than being radicalized through these internet videos' [82].

In a televised press conference in a media room (and not in a mosque) after the Via Rail plot was revealed, CAIR-CAN reminded Canadian Muslims to immediately notify police whenever they have knowledge of criminal activities. In denouncing the terror plot and reminding the media that the most important tip came from an imam, its executive director Ihsaan Gardee emphasized the everyday-ness of Muslims:

Like all Canadians, we want to feel safe and protected in our own country. We trust that our fellow citizens will see this for what it is: the alleged criminal and misguided actions of a few who do not reflect or represent Canadian Muslim communities [83].

Salam Elmenyawi, president of the Muslim Council of Montreal, similarly sought to show his community's separateness from the suspects and noted that no one seemed to know them from local mosques. He said the fact that the accused opted not to be represented by a lawyer demonstrates he is either "stupid or mentally ill," [84] clearly separating the suspect from mainstream Muslim groups. In this 2013 instance, in announcing the arrests, the RCMP thanked Muslim leaders for their help and publicly credited them with bringing a suspect to their attention [85].

As a flashpoint, the FBA debate in Ontario is thus illustrative of the need for PR by mainstream religious groups. Even if the 'average' Muslim would not attend, the public policy class that emerged at the IIT following the debate is an example of this emerging space. Individuals who have taken this class may be better equipped to steer conversations to what matters to them. Even if clear discrimination has been charted and Muslim Canadians are significantly under-employed in contrast with other religious groups ${ }^{18}$, the country's Muslim communities are conversant civic contributors.

The sophistication and significance of FBA for pro-Sharia groups was mired by problems in not specifically addressing the gender concerns of most critics and not translating their message to the "sound-bite" terms of the debate. However, events in the wake of the debate suggest an increasing recognition of the importance of public relations and opinion to better represent the positions of Muslims in Canada, the US and the UK. The challenge for these groups and individuals is to allow for a subtlety and depth of representation so that Muslimness does not necessarily become the sole defining feature of this political engagement should the interlocutors choose otherwise. This reductive understanding of identity, wherein religiously-determined behaviors and beliefs come to

18 Statistics Canada data 2001 show that despite a higher level of education than non-Muslims, Canadian Muslims' level of unemployment $(14,4 \%)$ is more than twice as high as the national average [86]. A 2004 CAIR-CAN study suggested that $43 \%$ of their 467 respondents knew at least one other Muslim who had, since 2001, been questioned by the RCMP (Royal Canadian Mounted Police), CSIS (Canadian Security Intelligence Service) or local police. More than half $(56 \%)$ had experienced at least one anti-Muslim incident since 9/11 [87]. 
solely encompass identities, parallels the over-reliance of the singular representation of the IICJ in the FBA debate in Ontario, Canada.

\section{Acknowledgements}

This paper has benefited from comments raised in a panel discussion at the 2012 American Anthropological Association meetings organized by James Bielo and Eric Hoenes del Pinal, as well as insights from Faisal Kutty and suggestions by anonymous reviews. I thank Katie Flood for her bibliographic assistance. Field research was conducted in the Greater Toronto area from January-August 2008 and July-August 2009 with support from a Fulbright Scholar award and with research funding from Memorial University of Newfoundland.

\section{Conflicts of Interest}

The author declares no conflict of interest.

\section{References}

1. Paul Statham, Ruud Koopmans, Marco Giugni, and Florence Passy. "Resilient or adaptable Islam? Multiculturalism, religion and migrants' claims-making for group demands in Britain, the Netherlands and France." Ethnicities 5 (2005): 427-59.

2. Alexandre Caeiro. "Religious Authorities or Political Actors? The Muslim Leaders of the French Representative Body of Islam." In European Muslims and the Secular State. Edited by Jocelyne Cesari and Seán McLoughlin. Aldershot: Ashgate, 2005, pp. 71-84.

3. Valérie Amiraux. "CFCM: A French touch?" ISIM Newsletter 12 (2003): 24-25.

4. Bronwyn Winter. Hijab \& the Republic: Uncovering the French Headscarf Debate. Syracuse, NY: Syracuse University Press, 2008.

5. Anne Phillips. Multiculturalism without Culture. Princeton: Princeton University Press, 2007.

6. Moira Dustin, and Anne Phillips. "Whose agenda is it? Abuses of women and abuses of "Culture" in Britain." Ethnicities 8 (2008): 405-24.

7. Veena Meetoo, and Heidi Safia Mirza. "There is nothing "Honourable" about Honour Killings: Gender, violence and the limits of multiculturalism." Women's Studies International Forum 30 (2007): 187-200. http://eprints.ioe.ac.uk/2018/1/meetooandmirza2007nothinghonourable187.pdf.

8. Talal Asad. Formations of the Secular: Christianity, Islam, and Modernity. Stanford: Stanford University Press, 2003.

9. Jürgen Habermas. "Notes on a post secular society." Sign and Sight, 18 June 2008. http://www.signandsight.com/features/1714.html/.

10. Jose Casanova. Public Religions in the Modern World. Chicago: University of Chicago Press, 1994.

11. Linda Woodhead. "Five concepts of religion." International Review of Sociology 21 (2011): 121-43.

12. Paul Heelas, Linda Woodhead, Benjamin Seel, Bronislaw Szerszynski, and Karin Tusting. The Spiritual Revolution: Why Religion is Giving Way to Spirituality. Oxford: Blackwell, 2005. 
13. Meredith B McGuire. Lived Religion: Faith and Practice in Everyday Life. Oxford: Oxford University Press, 2008.

14. Robert Orsi. "Is the study of lived religion irrelevant to the world we live in?" Journal for the Scientific Study of Religion 42 (2003): 169-74.

15. Robert Orsi. Between Heaven and Earth: The Religious Worlds People Make and the Scholars Who Study Them. Princeton, NJ: Princeton University Press, 2005.

16. Canadian Institute of Policy Studies (CIPS). "Muslim community profile survey." Canadian Institute of Policy Studies, 2008. Available online: http:/www.c-ips.ca/docs/ CIPS_Survey_Report.pdf(accessed on 12 August 2012).

17. Julie Macfarlane. Islamic Divorce in North America: A Shari'a Path in a Secular Society. Oxford: Oxford University Press, 2012.

18. Julie Macfarlane. "Understanding trends in American Muslim divorce and marriage: A discussion guide for families and communities." Institute for Social Policy and Understanding, January 2012. Available online: http://ispu.org/pdfs/ ISPU\%20Report_Marriage\%20II_Macfarlane_WEB.pdf (accessed on 12 August 2012).

19. Samia Bano. "Islamic family arbitration, justice and human rights in Britain." Law, Social Justice \& Global Development Journal 1 (2007): http://www.go.warwick.ac.uk/elj/lgd/2007_1/bano.

20. Ghena Krayem. "Multiculturalism and its challenges for Muslim women." In Challenging Identities: Muslim Women in Australia. Edited by Shahram Akbarzadeh. Carlton, Victoria: Melbourne University Press, 2010, pp. 105-29.

21. Asifa Quraishi, and Najeeba Syeed-Miller. "No altars: A survey of Islamic family law in the United States." Emory Law, n.d. Available online: http://www.law.emory.edu/ifl/cases/USA.htm (accessed on 6 September 2013).

22. Tariq Ramadan. Western Muslims and the Future of Islam. London: Oxford University Press, 2009.

23. Tariq Modood. "Multicultural citizenship and the anti-sharia storm." Open Democracy, 14 February 2008. http://www.opendemocracy.net/article/faith_ideas/europe_islam/ anti_sharia_storm\#.

24. Marion Boyd. "Dispute resolution in family law: Protecting choice, promoting inclusion." Ministry of the Attorney General, 20 December 2004, p. 191. Available online: http://www.attorneygeneral.jus.gov.on.ca/english/about/pubs/boyd/fullreport.pdf (accessed on 6 September 2013).

25. Paul Bramadat. "Beyond Christian Canada: Religion and Ethnicity in a Multicultural Society." In Religion and Ethnicity in Canada. Edited by Paul Bramadat and David Seljak. Toronto: Pearson Education Canada Inc., 2005, pp. 1-29.

26. Statistics Canada. "2001 Census Data: Religion (95) and Visible Minority Groups (15) for Population, for Canada, Provinces, Territories, Census Metropolitan Areas 1 and Census Agglomerations, 2001 Census - 20\% Sample Data." Government of Canada, 2001. Available online: http://www12.statcan.ca/english/census01/products/standard/themes/ RetrieveProductTable.cfm?Temporal=2001\&PID=55825\&APATH=3\&GID=431515\&METH $=1 \& \mathrm{PTYPE}=55440 \&$ THEME $=56 \&$ FOCUS $=0 \& \mathrm{AID}=0 \& \mathrm{PLACENAME}=0 \& \mathrm{PROVINCE}=0 \&$ 
$\mathrm{SEARCH}=0 \& \mathrm{GC}=0 \& \mathrm{GK}=0 \& \mathrm{VID}=0 \& \mathrm{VNAMEE}=\& \mathrm{VNAMEF}=\& \mathrm{FL}=0 \& \mathrm{RL}=0 \& \mathrm{FREE}=0$ (accessed on September 6, 2013).

27. PEW. "The Future of the Global Muslim Population: An Interactive Feature." PEW-Templeton Global Religious Futures Project, January 2011. Available online: http://features.pewforum.org/ muslim-population-graphic/\#/Canada (accessed on 6 September 2013).

28. Statistics Canada. "Selected Religions by Immigrant Status and Period of Immigration, 2001 Counts, for Canada, Provinces and Territories - 20\% Sample Data." Government of Canada, 2001. Available online: http://www12.statcan.ca/english/census01/products/highlight/religion/ Page.cfm?Lang $=\mathrm{E} \& \mathrm{Geo}=\mathrm{PR} \& \mathrm{View}=1 \mathrm{~b} \& \mathrm{Code}=01 \&$ Table $=1 \&$ StartRec $=1 \&$ Sort $=2 \& \mathrm{~B} 1=\mathrm{Can}$ ada\&B2 $=$ Counts (accessed on 6 September 2013).

29. Jack Jedwab. "Canada's Demo-Religious Revolution: 2017 will bring considerable change to the profile of the Mosaic." Association for Canadian Studies/Association d'études Canadiennes, 2005. Available online: http://www.acs-aec.ca/oldsite/Polls/30-03-2005.pdf (accessed on 6 September 2013).

30. Charles Lewis. "Number of Muslims in Canada predicted to triple over next 20 years: Study." The National Post, 31 January 2011. Available online: http:/www.nationalpost.com/todayspaper/2030+Canada+Muslim+population+triple/4200144/story.html (accessed on 8 August 2012).

31. Alexandre Caeiro. "The power of European fatwas: The minority fiqh project and the making of an Islamic counter public.” International Journal of Middle East Studies 42 (2010): 435-49.

32. Agence France-Presse. "Canadian imams condemn radical Islam." The National Post, 13 August 2012. Available online: http://ife.nationalpost.com/2010/08/13/canadian-imamscondemn-radical-islam/\#ixzz0xP2b45Yy (accessed on 9 December 2012).

33. Canadian Council of Imams. "Canadian council of imams: To serve those who serve." Canadian Council of Imams, 2012. Available online: http://www.canadiancouncilofimams.com/ (accessed on 6 September 2013).

34. Jennifer A. Selby, and Anna C. Korteweg. "Setting the Scene in Ontario." In Debating Sharia: Islam, Gender Politics and Family Law Arbitration. Edited by Anna C. Korteweg and Jennifer A. Selby. Toronto: University of Toronto Press, 2012, pp. 12-31.

35. John L. Esposito, and Natana J. DeLong-Bas. Women in Muslim Family Law, 2nd ed. Syracuse: Syracuse University Press, 2001.

36. Pascale Fournier. Islamic Marriage in Western Courts: Lost in Transplantation. Farnham, UK: Ashgate, 2010.

37. Christopher Cutting. "Faith-Based Arbitration or Religious Divorce: What Was the Issue?" In Debating Sharia: Islam, Gender Politics and Family Law Arbitration. Edited by Anna C. Korteweg and Jennifer A. Selby. Toronto: University of Toronto Press, 2012, pp. 66-87.

38. The Canadian Society of Muslims. "Our President." n.d. Available online: http://muslimcanada.org/csm_president.html (accessed on 6 September 2013).

39. Syed Mumtaz Ali. "Interview: A review of the Muslim Personal/Family Law Campaign." The Canadian Society of Muslims, August 1995. Available online: http://muslimcanada.org/pfl.htm (accessed on 6 September 2013).

40. Judy VanRhijn. "First steps taken for Islamic arbitration board." Law Times, 24 November 2003. http://www.freerepublic.com/focus/f-news/1028843/posts. 
41. Mahmood Mamdani. Good Muslim, Bad Muslim: America, the Cold War and the Roots of Terror. New York, Pantheon, 2004.

42. Nevin Reda. 'The 'Good' Muslim, 'Bad' Muslim Puzzle? The Assertion of Muslim Women's Islamic Identity in the Sharia Debates in Canada." In Debating Sharia: Islam, Gender Politics and Family Law Arbitration. Edited Anna C. Korteweg and Jennifer A. Selby. Toronto: University of Toronto Press, 2012, pp. 231-56.

43. Personal Interview, 22 January 2008.

44. Kevin Dougherty. "Québec bans sharia." Canwest News Service, 27 May 2005. http://www.sikhtimes.com/news_052705b.html.

45. Lorraine Weinrib. “Ontario's Sharia Law Debate: Law and Politics under the Charter." In Law and Religious Pluralism in Canada. Edited by Richard Moon. Vancouver: UBC Press, 2008, pp. 239-63.

46. Jamie Scott. The Religions of Canadians. Toronto: University of Toronto Press, 2012.

47. Canadian Islamic Congress. "Canadian Islamic Congress." 2011. Available online: http://www.canadianislamiccongress.com/cicfacts.php (accessed on 6 September 2013).

48. Haideh Moghissi, Saeed Rahnema, and Mark Goodman. Diaspora by Design: Muslim Immigrants in Canada and Beyond. Toronto: University of Toronto Press, 2009.

49. Anna C Korteweg. "The Sharia Debate in Ontario: Gender, Islam, and representations of Muslim women's agency." Gender \& Society 22 (2008): 434-54.

50. Faisal Kutty. "'Sharia' Courts in Canada: A Delayed Opportunity for the Indigenization of Islamic Legal Rulings." In Debating Sharia: Islam, Gender Politics and Family Law Arbitration. Edited by Anna C. Korteweg and Jennifer A. Selby. Toronto: University of Toronto Press, 2012, pp. 123-49.

51. Katherine Bullock. “'The Muslims Have Ruined Our Party:' A Case Study of Ontario Media Portrayals of Supporters of Faith-Based Arbitration." In DebatingSharia: Islam, Gender Politics and Family Law Arbitration. Edited by Anna C. Korteweg and Jennifer A. Selby. Toronto: University of Toronto Press, 2012, pp. 257-76.

52. Harvey Simmons. "One Law for All Ontarians." The Toronto Star, 14 September 2010. http://www.thestar.com/opinion/editorialopinion/article/860513--one-law-for-all-ontarians.

53. Natasha Bakht. "Were Muslim barbarians really knocking on the gates of Ontario?" Ottawa Law Review 35: (2006): 67-82.

54. Sian Powell. "Shamed by Sharia." The Weekend Australian, 26 June 2004, p. 21.

55. United Press International. "Muslims adopt Shariah legal code in Canada." 4 August 2004. http://www.upi.com/Top_News/2004/08/04/Muslims-adopt-Shariah-legal-code-in-Canada/ UPI-14001091627835/.

56. Salim Mansur. "Sharia's underclass." The National Post, 22 July 2005, p. A18. Available online: http://www.freedominion.ca/phpBB2/viewtopic.php? $\mathrm{f}=1 \& \mathrm{t}=42785$ (accessed on 6 September 2013).

57. Thunder Bay Chronicle. "Pro-shariah Muslim women decry decision to axe faith arbitration." Thunder Bay Chronicle, 15 September 2005.

58. Canadian Islamic Congress. "'Sharia' defines who we are' says Islamic Congress: Fears of potential abuse called unfounded." CIC Media Communiqué, 24 August 2004. Available online: 
http://www.canadianislamiccongress.com/cic2010/2004/08/28/sharia-defines-who-we-are-saysislamic-congress-fears-of-potential-abuse-called-unfounded/ (accessed on 6 September 2013).

59. Lori G Beaman. "Introduction." In Religion and Canadian Society, 2nd ed. Edited by Lori G. Beaman. Toronto: Canadian Scholars' Press, 2012, pp. 1-6.

60. CAIR-CAN (Canadian Council of American-Islamic Relations). "Review of Ontario's Arbitration process and arbitration act. written submissions to Marion Boyd." CAIR-CAN, 10 August 2004. Available online: http://www.caircan.ca/downloads/sst-10082004.pdf (accessed on 6 September 2013).

61. Rita Trichur. "Muslims divided over whether sharia belongs in Ontario arbitration law." Canadian Press Newswire, 22 August 2004. http://www.religionnewsblog.com/8496/muslimsdivided-over-whether-sharia-belongs-in-ontario-arbitration-law.

62. Canadian Islamic Congress. "'Sharia' defines who we are' says Islamic Congress: Fears of potential abuse called unfounded." CIC Media Communiqué, 28 August 2004. http://www.canadianislamiccongress.com/cic2010/2004/08/28/sharia-defines-who-we-are-saysislamic-congress-fears-of-potential-abuse-called-unfounded/.

63. Marina Jimenez. "Arbitration based on faith is working, Muslim group says." The Globe and Mail, 11 September 2004, p. A11. http://www.theglobeandmail.com/news/national/arbitrationbased-on-faith-is-working-muslim-group-says/article1004089/.

64. Faisal Kutty. "Boyd's Recommendations balance needs of religious communities with rights of vulnerable." The Lawyers Weekly, 21 January 2005. http://www.lawyersweekly.ca/ index.php? section $=$ article\&articleid $=20$.

65. Canadian Council of Muslim Women. "CCMW submission to Marion Boyd - review of the Ontario arbitration act and arbitration processes specifically in matters of family law." Canadian Council of Muslim Women (CCMW), 2004. Available online: http://beta.ccmw.com/ wp-content/uploads/2013/04/CCMW-Submission-to-Marion-Boyd-Review-of-the-OntarioArbitration-Act-and-Arbitration-Processes-Specifically-in-Matters-of-Family-Law-July-2004.pdf (accessed on 6 September 2013).

66. Marina Jimenez. "Decision on Shari'a sparks Jewish protest." The Globe and Mail, 13 September 2005. Available online: http://www.theglobeandmail.com/servlet/ArticleNews/ TPStory/LAC/20050913/SHARIA13VTPNational/TopStories (accessed on 6 September 2013).

67. Scott R Stroud. "John Dewey and the question of artful communication." Philosophy and Rhetoric 41, no. 2 (2008): 153-83.

68. Valérie Amiraux. "Headscarves in Europe: What is really the Issue." In European Islam: Challenges for Society and Public Policy. Edited by Samir Amghar, Amel Boubekeur and Michel Emerson. Bruxelles: CEPS, 2007, pp. 124-43.

69. Birgit Sauer. "Headscarf regimes in Europe: Diversity policies at the intersection of gender, culture and religion." Comparative European Politics 7 (2009): 75-94.

70. Jennifer A Selby. "Islam in France reconfigured: Republican Islam in the 2010 Gerin Report." The Journal of Muslim Minority Affairs 31 (2011): 383-98.

71. Anna C Korteweg. "Understanding honour killing and honour-related violence in the immigrant context: Implications for the legal profession and beyond." Canadian Criminal Law Review 16, no.2 (2012): 135-60. 
72. Pascale Fournier, and Erica See. "The "Naked Face" of secular exclusion: Bill 94 and the privatization of belief." Windsor Yearbook of Access to Justice 30 (2012): 63-76.

73. Nancy J Davis, and Robert V Robinson. "Religious orthodoxy in American society: The myth of a monolithic camp." Journal for the Scientific Study of Religion 35 (1996): 229-45.

74. Rajeev Bhargava. "States, religious diversity, and the crisis of secularism." Open Democracy, 22 March 2011. http://www.opendemocracy.net/rajeev-bhargava/states-religious-diversityand-crisis-of-secularism- 0 .

75. Personal Interview, 15 January 2008.

76. Alexandra Brown. "Constructions of Islam in the context of religious arbitration: A consideration of the "Shari'ah Debate" in Ontario, Canada." Journal of Muslim Minority Affairs 30 (2010): 343-56.

77. Alexandra Brown. "Managing the Mosaic: The Work of Form in 'Dispute Resolution in Family Law: Protecting Choice, Promoting Inclusion." In Debating Sharia: Islam, Gender Politics and Family Law Arbitration. Edited by Anna C. Korteweg and Jennifer A. Selby. Toronto: University of Toronto Press, 2012, pp. 329-50.

78. Jennifer A Selby. “Construing the Secular: Implications of the Ontario Sharia Debate." In Debating Sharia: Islam, Gender Politics and Family Law Arbitration. Edited by Anna C. Korteweg and Jennifer A. Selby. Toronto: University of Toronto Press, 2012, pp. 351-76.

79. Islamic Circle of North America (ICNA) Press Kit. "Defending religious freedom: Understanding Shariah.” ICNA National Campaign, October 2011-December 2012. Available online: www.defendingreligiousfreedom.com (accessed on 6 September 2013).

80. Marta Bolognani, and Paul Statham. "The changing public face of Muslim associations in Britain: Coming together for common 'social' goals?” Ethnicities 13 (2013): 229-49.

81. Daniel Nilsson DeHanas and Zacharias P Pieri. "Olympic proportions: The expanding scalar politics of the London 'Olympics Mega-Mosque' controversy.” Sociology 45 (2011): 798-814.

82. CBC News. "What the analysts are saying about alleged train plot." CBC News, 23 April 2013, http:/www.cbc.ca/news/canada/story/2013/04/23/f-via-plot-analysis.html.

83. Bruce Deachman. "Ottawa imams would 'never hesitate' reporting any activity to police they thought might cause harm." Ottawa Citizen, 23 April 2013. Available online: http://www.ottawacitizen.com/news/Ottawa+imams+would+never+hesitate+reporting+activit $\mathrm{y}+$ police/8284232/story.html (accessed on 6 September 2013).

84. The Canadian Press. "Muslim groups thank police for foiling terror plot, denounce distortion of Islam.” Macleans, 23 April 2013. http://www2.macleans.ca/2013/04/23/muslim-groupsthank-police-for-foiling-terror-plot-denounce-distortion-of-islam/.

85. CBC News. "Via terror plot suspects deny allegations." 23 April 2013. http://www.cbc.ca/news/politics/story/2013/04/22/terror-plot-suspects.html.

86. Jennifer A Selby. "Islam in the west: Canada country profile." Euro-Islam Website, 2008. Available online: http://www.euro-islam.info/spip/article.php3?id_article=2336 (accessed on 6 September 2013).

87. CAIR-CAN (Canadian Council of American-Islamic Relations). "Presumptions of guilt: A national survey on security visitations of Canadian Muslims." 8 June 2005. Available online: http://www.caircan.ca/downloads/POG-08062005.pdf (accessed on 12 August 2012). 


\title{
Learning to Be Muslim-Transnationally
}

\section{Louise Cainkar}

\begin{abstract}
This essay discusses the religious upbringing experiences and reflections upon them articulated by 53 Muslim American youth who were interviewed as part of a larger sociological study of Arab American teenagers living transnationally. On extended sojourns in their parents' homelands, these youth - most were born in the US although some migrated to the US at a young age-were taken "back home" to Palestine and Jordan by their parents so they could learn "their language, culture, and religion". They were asked about learning to be Muslim in the US and overseas in the context of a much larger set of questions about their transnational life experiences. The data provide insights into the various types of early religious learning experiences Muslims have access to in a US Christian-majority context. The essay then examines how these youth later experienced and interpreted being Muslim in a place where Muslims are a majority. The study found that while a majority of youth said they learned more about their faith, almost half (42\%) said that it was the same as in the US, that they did not learn more, or that the experience contributed both positively and negatively to their religious understanding. Key to these differences was the character of their experiences with being Muslim in the US. A majority of girls and of youth who attended full-time Islamic schools and/or were part of a vibrant Muslim community in the US gave one of the latter responses. On the other hand, most of the boys who grew up isolated from other Muslims in the US reported learning more about Islam. They were especially pleased with the convenience of praying in mosques and with being able to pray in public without stares. The data show that living where one is part of the dominant religious culture does not necessarily make for a deeper experience of religion. What seems to matter more is the type of experience with being Muslim each youth brings into the situation, as it was these that informed their subjective interpretations of what it means to be Muslim.
\end{abstract}

Reprinted from Religions. Cite as: Cainkar, L. "Learning to Be Muslim-Transnationally." Religions 5 (2014): 594-622.

\section{Overview of Findings}

This study's data on religious upbringing in the US show that family, especially mothers, are the most important transmitters of Islamic religious beliefs and practices to young children, a finding consistent with studies of the transmission patterns within other religious groups in the United States. Parents often tapped the resources of Saturday or Sunday schools to reinforce family 
teachings, but these were not always available nearby. Youth who attended these schools $(38 \%$ of sample) largely described them as not particularly helpful, mainly because of their reliance on memorization, focus on historical figures rather than contemporary matters, and because they felt that classes were taught by untrained teachers. The data also suggest that the intermittent nature of these programs in combination with their significant distance from students' homes failed to create community among young Muslims, where friendship and solidarity could be experienced and teachings could be reinforced. On the other hand, some $20 \%$ of the youth interviewed in this study attended full-time Islamic schools for at least some part of their childhood in the US and were overwhelmingly positive about such experiences, in significant measure precisely because they created such community. Eleven percent of the interviewees said they had had no Islamic religious education in the US.

This particular analysis of study data also sought to understand whether, and in what ways, youth who spent their early years in the US found living in a Muslim majority context helpful to their religious growth and understanding, and if there was any relationship between the types of religious education they had in the US and their interpretations of these experiences. For example, were youth who had only family-based religious education more likely to view living in a Muslim majority country as helpful to their religious understanding than youth who had multiple sources of education, or did these resources not matter? Findings show that a majority of youth $(58 \%)$ said that living in a Muslim majority place improved their religious growth and understanding. However, a substantial minority (42\%) said that it did not help, that is was the same, or that it both helped and hindered. Youth who said they learned about Islam and being Muslim from their family alone in the US were the most likely to say that the experience of living "back home" was beneficial to their religious learning, while those who had attended full-time Islamic schools in the US were more likely than other youth to say that they did not learn more about their religion in a Muslim majority context, that it was the same, or that it was unhelpful. Youth who attended weekend Islamic classes answered in both ways, suggesting that something other than a linear process of religious learning is at work, that other variables come into play to influence their experiences and interpretations. Religious learning outcomes were clearly gendered, as girls were much more likely than boys ( $71 \%$ versus $44 \%)$, independent of religious education in the US, to say that the experience was not helpful, the same, or that it had elements that helped and elements that did not. Indeed, girls and boys spoke about and experienced religion in very different ways "back home". When girls spoke about expressions of their religious faith, they referred mainly to ways of dressing and behaving around others, but when boys spoke about the same subject they talked mainly about praying.

This essay lays out in an organized and descriptive fashion the youth's recollections of their early religious learning experiences in the US as well as their commentary on their overseas experiences of religion, especially whether and how such experiences contributed to their religious understanding and growth. The data clearly show that youth interpret "indigenous expressions" of religion [1] in multiple ways and that these interpretations are informed by their previous US experiences. Their observations and experiences of presumed "religious authenticity" do not necessarily produce the outcomes expected by their parents, nor those of religious leaders and scholars who believe that immersion in a Muslim majority climate is beneficial to the religious 
formation of young Muslims growing up in places where they are a minority. What seems to matter more is the quality of that experience, and that is a subjective interpretation informed by the prior experiences each youth brought into the situation.

\section{The Importance of Family, Congregation, and Society in Religious Upbringing}

Sociological studies of religious upbringing ${ }^{1}$ in the United States have tended to focus their analyses on two levels: the family and religious congregations. Although most US studies have been of Christians and secondarily of Jews, the recent upsurge in immigration to the US has provoked research on a range of other religious groups. Studies of the roles of family and community institutions in religious upbringing consistently find that the most significant actors in the religious education of children are the family, especially the mother, followed by religious institutions and their attendant congregations. Parents transmit religious beliefs and values and model religious practices within the home [1-3]. When parents are members of religious congregations, they convey their congregations' perspectives and beliefs on matters such as piety, faithful practice, authenticity, and religious authority. It is the parents who funnel their children into religious schools and institutions, their worship services, religious education classes, and affiliated social groups - the places where children learn "what it is that my religious tradition teaches" [4]. Speaking to the importance of religious congregations for conveying beliefs, Edgell (speaking mainly about Christians) notes:

People get religious ideas through a variety of sources, and people pursue a variety of paths to express their religion. But when it comes to asking questions about what it is that I believe or we believe as a religious community, congregations are probably the place for many, many people [4].

The growing body of sociological research on religion among immigrants and their children in the US tends to be focused on religious congregations (institutions and their communities). This literature finds that religious congregations play additional formative roles to those mentioned above: they aid in immigrant adjustment to the new place of residence and in the formation of second-generation identity and a sense of belonging [5-7]. The few studies that have addressed religious practices in the home confirmed that these are important to the religious upbringing of the children of immigrants [1,6,8]. Park and Ecklund, who studied second-generation Asian Americans of five different religious faiths, found a significant role for a more broadly defined extended family, in which mothers had the central influence, across all of the groups studied. The family's influence overlapped with the congregation as "parents provided the means by which children receive religious training in the congregation and provide models of participation and leadership for children" ([1], p. 98). They also found that "home-based religious practices" (reading the Qur'an or the Bible to children, reciting family prayers, receiving moral instruction) were equally important for all of these groups, even though they had assumed they would be more important for religious groups with fewer institutional and organizational resources. Additionally, they found that

\footnotetext{
Religious upbringing is a more broadly encompassing term than "the religious education of children"; it draws directly from the Arabic word tarbiyya, which connotes both formal education and ways of being and acting. Amer, one of the youth interviewed, described tarbiyya as "learning how to be a good human being".
} 
"international family visits" were especially important to the religious socialization and understanding of Hindu youth: "visits to relatives in distant countries linked children and young adults to indigenous expressions of religion" ([1], p. 107). Recent studies [9,10] have examined the impacts of transnational journeys embarked upon by American Muslim adults in order to develop deeper religious understanding. More than seeking to experience "indigenous expressions" of religion, these adults intentionally sought out specific religious teachers, who were often critical of local practices and indigenous expressions. In contrast to these adult seekers, the youth discussed here mainly interacted with Islam as locally practiced, taught in schools, and understood within the family, but across two very different places. In the US, these sources not only taught them what it means to be Muslim, they informed their expectations of what being Muslim would be like in a Muslim majority society, a perspective they carried with them overseas that imposed upon their interpretations of local religious teachings and behavior. In this way they were different from their parents and from local youth, often questioning matters that others may have taken for granted. Their transnational lens (see, e.g., [11]), informed by but not bound to Islam as practiced in the US or in their parents' homelands, was a resource they consulted when considering what they were being taught about Islam and how they would practice their religion, or if they would practice it at all. This unique transnational positionality adds a layer of complexity to what might actually be occurring during international family visits, such as those cited by Park and Ecklund. Finally, most studies of religious groups in the US, whether of new groups or of Christians and Jews, treat the Christian-majority social context of the United States as normative. Few have examined the specific ways that dominant social structures and cultures infused by a religious normativity, where certain religious beliefs, values, and calendars are taken for granted, affect the daily lives and sense of belonging of members of minority religious traditions (see, e.g., [5,12,13]). The data from this study speak to these impacts as described by youth, whose insights on how these matter are keener once observed through a comparative lens.

\section{Methods}

This analysis is based on interviews conducted by the author in 2011 with 53 Arab American Muslim youth whose parents had taken them "back home" to Palestine or Jordan to learn their language, religion, and culture (the reason stated by nearly every youth interviewed), including twenty five females and twenty eight males. While they had moved from the US at various ages, depending on their placement among siblings and other family-related variables, and some had been born overseas, all were juniors or seniors in high school in Palestine or Jordan when interviewed for this study. The youth saw these overseas experiences as temporary sojourns; the overwhelming majority said they intended to return to the US as adults. Most of the interviews were conducted at high schools in the Jerusalem-Ramallah area (Palestine) and in greater Amman (Jordan), mainly because high schools are the best places to find such youth and these geographic locations are where schools catering to English language speakers have been established. School principals assisted me in locating students eligible for the study [raised in the US, high school junior or senior], sent study information and consent forms home to parents, and then excused participating students from classes so I could interview them. The interviews selected for this analysis were part of a larger study of transnational Arab American teenagers that also includes 
youth from Yemen as well as Christians. The findings reported here are thus not from an in depth study focused on religion, but one that examined transnational experiences in which religious learning is one aspect.

Youth in the study grew up in a wide range of places in the US; many were not raised in large cities or in places where other Muslims lived nearby. Youth living in Palestine and Jordan reported growing up in thirty-four different US cities and towns; less than half said there was an Arab or Muslim community in the place that they lived. The strength of this sampling method is that it does not have the congregational bias so often found in studies of members of religious groups, nor the focus on a concentrated ethnic community. We are able to learn about the experiences of Muslims living on the edge, whose daily lives are performed in a context where they are often swimming alone. One of its drawbacks is that it underplays what it's like to be Muslim in the US when surrounded by a Muslim community with robust Muslim institutions. Through examining these youths' recollections of learning to be Muslim and their narratives of current experiences we gain insights into what they consider to be the key agents and methods of their early religious socialization in the US as well as into how they interpret the "indigenous expressions of religion" they are engaged with "back home". As with all data that taps into memories, their recollections of earlier experiences should be understood as such. That is, when youth describe how and what they learned about Islam as children in the Unites States, they are recounting what they remember as meaningful, rather than expressing verifiable factual details.

\section{Learning to be Muslim in the US}

Interviewees described five main patterns of religious learning during their childhoods in the United States, including one described by $11 \%$ as none at all (see Table 1). The most common method cited (32\%) was through their parents and extended family (sometimes including nonrelated adults), followed by $19 \%$ each citing Saturday or Sunday school, full-time Islamic school, or Saturday or Sunday school and family. The meaningful difference between the number of males and females offering the latter response suggests that something is going on: perhaps multiple-methods (weekend school and family) were utilized more frequently with females than males, or perhaps males were more likely to forefront formal instruction and de-emphasize (and thus render invisible) instruction that occurred in the informal sphere of the home. Youth who attended full-time Islamic schools in the U.S., who were more likely to be male than female, considered these schools as their primary source of religious education and usually did not mention family. That is, while half of the youth specifically identified family as a source of religious education, we should not conclude that family was uninvolved in the religious education of other half but rather that they imputed greater importance to formal, institutional educational venues, even if they did not find them useful.

Place matters with regard to the resources parents have access to for their children's religious education. Despite significant growth in number and size of Muslim institutions in the US [13], not every U.S. city has a full-time Islamic school, and many Muslim families live at significant distances from mosques where they can worship or institutions offering weekend classes ${ }^{2}$. Many

2 Not sure why this is here. Appears again on page 6. According to Bagby’s ([14], p. 4) study of mosques in the US, about $80 \%$ of mosques are in large cities and their suburbs. "The number of mosques and mosque participants 
youth interviewed in this study attended a mosque service only on religious holidays, citing distance as the main barrier to more frequent attendance. The locations of youth who attended full-time Islamic schools attest to these limitations as they grew up in the large cities of Chicago, Milwaukee, Detroit, Atlanta, Boston, Brooklyn, and Miami. At the same time, there were plenty of youth from these same cities who did not attend full-time Islamic schools, highlighting matters of proximity, cost, and parental preference.

Table 1. Cited Responses to: "How did you know you were a Muslim? How did you learn about your faith when you were younger?"

\begin{tabular}{llllll}
\hline$\# / \%$ & Parents/Family & $\begin{array}{l}\text { Weekend } \\
\text { Classes }\end{array}$ & $\begin{array}{l}\text { Parents/Family \& } \\
\text { Weekend Classes }\end{array}$ & $\begin{array}{l}\text { Full-Time } \\
\text { Islamic School }\end{array}$ & $\begin{array}{l}\text { No Religious } \\
\text { Education }\end{array}$ \\
\hline $\begin{array}{l}\text { Total }=53 \\
\%\end{array}$ & 17 & 10 & 10 & 10 & 6 \\
& $32 \%$ & $19 \%$ & $19 \%$ & $19 \%$ & $11 \%$ \\
Females $=25$ & 8 & & & & \\
$\%$ & $29 \%$ & 5 & 7 & 3 & 2 \\
& & $21 \%$ & $29 \%$ & $\mathbf{1 2 . 5 \%}$ & $8 \%$ \\
Males $=28$ & 9 & 5 & 3 & & \\
$\%$ & $34 \%$ & $17 \%$ & $\mathbf{1 0 \%}$ & $24 \%$ & $14 \%$ \\
\hline
\end{tabular}

\subsection{Learning from Family}

Youth who said they learned how to practice their Islamic faith from family members spoke of their parents', especially their mothers', endeavors to read Qur'an to them, teach them how to speak Arabic, pray, and fast during Ramadan. Families were most effective, however, according to the interview accounts, at transmitting moral lessons on how to distinguish between good and bad as a Muslim and in conveying their interpretations of the behavioral boundaries of the religion. These elements of the faith, which we might call a Muslim ethos and its daily life application, were repeatedly referred to by youth as either the "rules" or the "basics," and were often framed in comparison to what "Americans" do. Indeed, learning "the rules" and how to fast were mentioned more often than any other aspect of religious education within the family and for many youth the "rules" were their main take-away and had the most memorable impact. Listening to these teens describe the pedagogical process, one can sense the challenge parents faced raising their children as Muslims in the US and appreciate why they thought taking them "back home" would be beneficial to their Muslim upbringing.

When asked how she learned about her religion, Sawsan replied: "Our parents, my mom mostly. She was always like 'You are living in America, but you are a Muslim. You're living in America, but you have to follow my rules. And Islamic rules.' And she always kept the Islamic boundary around us." The notion of boundaries carried the message that good and bad for Muslims were different from good and bad for "Americans." Indeed, Mohammed said it was better for a Muslim to be raised in Palestine than in the US because if a Muslim stays in the US “maybe he's going to do

continue to show significant growth. The vast majority of mosques are located in metropolitan areas but the percentage of mosques in urban areas is decreasing and the percentage of mosques in suburban areas is increasing." 
things wrong, not listen to his parents." When asked what kind of wrong things, he replied, "Like drink beer. Go out with girls. Like other things, you know what I mean..." And then he clarified, "I'm not talking about the Americans. I'm just saying for like us." Mohammed felt that his experience in Palestine would help him teach his own kids "what's right from wrong for a Muslim".

Ziad, who learned about religion from his parents and also attended weekend school, described the boundary as a "red line" for Muslims:

Um my parents weren't so strict as uh being, in a religious way, but they also kept like a red line. You know like don't cross this line because that's against our, against Islam. So I would stay behind that line. [Give me some examples of the lines.] Red lines? Like um like we would watch TV, regular, but we shouldn't like you know watch things that has a lot of nudity. Also no kissing, no touching, you know, those kind of stuff. [Anything else?] No, not really. [Did they have books for you to learn from?] Well yeah they had the Qur'an for us in the house, but I didn't know how to read Arabic, so that wasn't a lot of help.

Diala, who spoke of receiving religious guidance from her mother, grandmother, and Muslim family friends, felt that she did not learn as much as she would have liked, but she knew the "basics":

I mean my mom was mainly the person to teach us about religion... So yeah, I mean, although we didn't get exposed to as much Arabic and religion as I would have liked at home, you know, we still knew the basics. You know, we don't have boyfriends and, but they made me understand why, and although they were never really um strict about what I wore, I don't know, naturally I just, I didn't feel comfortable wearing shorts anymore.

Still, Diala distinguishes between knowing religious practices and understanding why Muslims engage in these practices. She did not learn the "why" until she moved to Palestine.

But to be honest with you, when coming here, to Palestine, I-we did-technically we did not know that much about religion. You know? I mean, yeah, we knew Muslims prayed and fast, and we did fast, and, you know, you're supposed to wear the hijab. I never understood why though until I came here, until I got older. So, I mean, I wish my mom had-

Miriam's account describes her parent's efforts to convey the "traits" of a Muslim, which required developing an understanding of good and bad from a Muslim perspective. She considered these efforts more successful than their attempts to teach Qur'an, which were no doubt difficult because the Qur'an is written and taught in the Arabic language.

We would, say it was night, we have nothing to do, so my dad would just gather us all, and he'd just like read a hadith [sayings of the Prophet] out of the hadith book, and explain it, like, the traits of a Muslim where you can't lie, basically, you have to help each other...the whole idea of like you're either a good person or you're a bad person... My mom would try and get us to write the Qur'an, and try to translate it in our own way and what it means and stuff like that, on like it was Friday mornings. No sorry, it was Saturday mornings where we used to do that. But that also didn't last.

Youth who learned how to be a Muslim from their parents and extended family alone tended to be from places in which they had limited exposure to and interaction with other Muslims. Their neighbors were not Muslim, few if any other children at school were Muslim, and they reported 
visiting a mosque only occasionally, usually during Ramadan and the Eids [feasts], due to distances. I should note however, that none of the youth interviewed for the study cited attending services at a mosque as part of their religious learning experience. This is probably because learning is not catalyzed in situations where one feels somewhat out of place: their Arabic language skills were limited, they did not know the prayer ritual well, and many were not regular members of the congregation.

\subsection{Weekend Classes}

Youth who attended Saturday or Sunday school, including those who specifically also mentioned their parents as teachers and those who did not, had the benefit of growing up where this resource was available, although for many the schools were located at a significant distance from their homes. They described weekend schools as places where they were taught how to pray, memorize Qur'an, speak and read Arabic, and learn the rules. Some also spoke of learning about the prophets. The educational content of the weekend schools was thus similar to that of the home with the addition of language learning, memorizing Qur'an, and Islamic history. Adnan put it this way: "My parents they taught me most of the things like how to pray and things like that and Sunday school I learned more about prophets and stuff like that..."

Nearly unanimously, youth recounted the weekend school experience as not beneficial to learning to be Muslim, whether they had educational back up in the home or not. Hasheema said, "I went to a Saturday school, basically, growing up, until I got big and then I just stopped going because we didn't really learn much." Reflecting on what he had gained from attending weekend school during the summers, Samer reported, "When I got here I did not know that much." Similarly, Aisha, who attended Sunday school for Arabic language and religion, simply recounted, "it was difficult to learn about them, but I know there was more to see over here." Many complained about the memorization required, which they viewed as unhelpful to learning. Many also described their teachers as lacking qualifications to teach religion. As Yara put it, "teachers are just like volunteers." Similar to those who learned to be Muslims from family alone, learning the "rules" or "the basics" was what youth who attended weekend classes recalled most. These youth described going to a mosque very occasionally, more often during Ramadan and the Eids, and, as noted above, did not describe these visits as learning experiences. Students commonly lived at significant distances from each another and the weekend courses were episodic, so there was little opportunity for these young Muslims to develop community with each other. Consequently, with few Muslims in their neighborhood and social life mainly revolving around family, there was limited external reinforcement, support, or reward for being Muslim.

\subsection{Full-Time Islamic Schools}

Youth who attended full-time Islamic schools described learning how to pray, fast, speak Arabic, and memorize Qur'an. Notably, they did not to refer to their religious education as learning the rules, the basics, or the boundaries, probably because it offered so much more. For example, Etedal said she "knew everything" before moving to Palestine because she went to an Islamic school, unlike her brother, who only knew the basics. She does note, however, that in Palestine she 
learned about the everyday practice of being Muslim, the repertoire of daily life values and behaviors that compliment worship and rituals.

Well because I went to a private school I already knew all this stuff, so I didn't really learn any — much here. No, I already knew everything before I came. And now I know how to act, I know like the right way to act, to behave, treat your family and friends and everything like that. I knew that but, like, my younger brothers didn't know that, they like, they knew the basics and everything, but they didn't know much.

It is likely that prior to living in Palestine Etedal knew this repertoire, yet in Palestine its performance is more spaciay comprehensive as the expectations of behaving with propriety exist everywhere and are reinforced through the observation of others, including strangers. Etedal says: "I became more mature, and I learned, you know, the way you're supposed to behave here, and act and everything. You know, that everything, like, everybody's watching you here basically. And that was basically it."

Most of the youth who attended full-time Islamic schools made a point about how great it was to be part of a community of young Muslims. Lina said fondly, "I felt like I was surrounded by religion everywhere" as prayer rituals were woven throughout the school day. Nasreen recalls:

I love how they would, uh, you know in Islam we have like our five prayers, five daily prayers. They would have like during the school time. Uh, we have the mid-day prayer. We have to pray it.

We can assume that these positive feelings about Islamic schools speak to their contribution to happy childhood experiences in the US but also to something that is missing overseas, something they would not miss were it not for their transnational lives. Some youth said they missed the sense of community that was created at the school and carried over to the nearby mosque. In the Muslim majority world, mosques are mainly places where men go to pray and listen to sermons, while in the US most mosques house congregations composed of families. For example, Saif said:

Here I don't have that great of a connection with the mosque. For example in America the mosque was for me was a community, people would be going, talking, here the mosque is just, it's a mosque, it's a place where you pray and then you leave.

Youth who attended full-time Islamic schools also talked about having classmates who were of different nationalities. Khalil had great memories of his Islamic school, where his classmates were from India, Pakistan, Afghanistan, and other Arab countries. Although he did not see them much outside of school, he said they always looked forward to collective activities like fundraisers. The racially and ethnically diverse context of full-time Islamic schools in the US spawned their awareness of a religious faith, an Islam, that was not tied to a single culture, as it was with their immigrant parents.

In Islam for example it's a religion that's based on unity of people no matter the race. Before anything, we're Muslims. So we used to interact a lot. We wouldn't feel that there was much of a difference.

Boys and girls who attended full-time Islamic schools (as well as girls more generally) were the ones most likely to say that they did not learn much more about their faith while living overseas, and many of them were disappointed with their experience of religion in a Muslim majority society. The benefits they were told of living in such a society for their religious growth eluded 
them, and this was not simply because they felt they had already learned enough about their religion. Having been educated in a multi-ethnic community of Muslims where presumably the Islamic pedagogy was cleansed of cultural variations, they found that Islam as practiced "back home" was too culturally bound.

\section{Learning Religion "Back Home" in Palestine and Jordan}

During the course of interviews, youth were asked how living in Palestine or Jordan, both Muslim-majority contexts, affected their religious knowledge, growth, and personal experiences as Muslims. They were specifically asked: "Has being here helped you in your understanding of Islam?" and "How is it different being a Muslim here than being a Muslim in the US?" responses to which were probed for details. The following discussion is based on responses to the first question, with responses to the second question providing further insights. We expect that being Muslim in a Christian-majority context is quite different from being Muslim in a Muslim-majority context. In one case your religious rituals, calendars, diet, and modes of dress are at odds with the majority culture while in the other case they are normative. Theoretically at least, the same distinction should apply to dominant social values and norms of appropriate behavior, although being understood as humanly rather than divinely constructed these are more subject to variations associated with class and place and to change over time. Furthermore, technologies of globalization are making obvious inroads into local cultures, informing the musical and material tastes of youth. Nonetheless, the fact that these youth were taught while growing up that Muslims have different boundaries than "Americans" and that knowing how to conduct life within such boundaries turned out to prepare one well for social life in Palestine and Jordan indicates that these cultures are infused with a local variant of Islamic norms and values. However, as we will see below, the unique transnational lens of these youth produced varying interpretations of whether being Muslim in such a context was all together better. Some saw the dominant culture as productive of a mechanical conformity, different from the deeply considered actions driven by faith they were taught, and found that disconcerting. Thus, while one might assume that living in a Muslim majority context enhances religious learning in ways that cannot be achieved in a Muslim minority context, which is certainly something parents believed to be the case when they took their families overseas, the data show that these teenagers do not necessarily see it the same way. While some, especially boys, were thrilled by their freedom to be Muslim and especially their ability to pray wherever they wanted, others, especially girls but also many boys, were disappointed when the moral geography of Palestine and Jordan was not what they expected. They were surprised to discover that many Muslims did not practice their faith dutifully by praying five times a day, or by praying at all. They were also disheartened by what they saw as a lack of behavioral and moral consistency when persons who publicly performed acts of faith [praying, wearing hijab] acted in other settings in ways they considered un-Islamic. These observations, because they defied their expectations, are products of their US-based experiences that taught them to see Muslims in very fixed and sometimes very ideal ways, whether from a mainstream American culture that represents Muslims in religiously essentialized, non-complex ways, or from their religion teachers at home and in school who often contrasted how others behave to how "we" Muslims behave. What they 
found instead were human beings, with all the variations and vulnerabilities that implies, a social fact that locally-raised youth likely took for granted.

When responses to these questions are examined by the type of religious education youth had received in the US before going to Jordan or Palestine, the data show that those who learned religion from their family members alone and those who reported no prior religious education gained the most from living "back home." This outcome is not surprising given that their starting position was one of limited information. On the other hand, youth who attended full-time Islamic schools at some point during their childhood in the US were the least likely to say they experienced gains in knowledge and understanding. Youth who attended Islamic weekend schools were split: some said they learned more while others said that they did not, that there were positive and negatives, or that it was the same. Girls who attended weekend schools were more likely than boys who did so to offer a nuanced analysis (both positive and negative) or to say it was the same. The opinions and insights expressed below are based on the observations of youth informed by their unique position as transnational learners of Islam. Rather than treating their views as the perspectives of adolescents - persons at a developmental stage of growth - I see them as having a certain type of integrity that is less obfuscated by the demands of conformity imposed on geographically situated youth or adults. In my view, based on much research, their in-betweeness or liminality makes of them keen observers. The answers and explanations these youth gave in response to questions about learning religion and being Muslim provide key insights into the complex ways that religion, gender, and society intersect in two geographic locations. After a brief exploration of gendered differences, the data are organized according to the three levels of social organization they discussed when describing their religious learning experiences-schools, community, and society.

\subsection{Gendered Differences}

A majority (31, or $58 \%$ ) of the 53 youth interviewed said that their knowledge and understanding of Islam increased while living in Palestine or Jordan. On the other hand, 42\% (22) said either that it did not contribute positively to their religious understanding, that it contributed in both positive and negative ways, or that it made no difference. Boys were far more likely than girls to say that their knowledge and understanding of Islam increased ( $71 \%$ versus $44 \%$ ). Reasons for this distinctly gendered difference would benefit from ethnographic study, but study data and prior research by the author suggest three explanatory variables: gendered patterns of upbringing, role of mosques, and cultural perspectives on Muslim men. With regard to upbringing, Muslim parents in the US place more emphasis on teaching girls the "rules" than boys and expect more conformity to them from girls than from boys. Girls are therefore better prepared for the Islamic flavor of daily life in the social environment "back home", while boys have a sharper learning curve.

Mohammed's rendering of how he learned Islam in the US highlights this focus on girls:

I remember how my mom was in America and we were in America, my mom sat with my sisters and she was telling them, she was teaching them what a Muslim can do and what a Muslim can't do and they listened. They know that when they go to school, they can't do nothing wrong. They know that they can't eat beer — or drink beer or eat pork or anything cause in our din — in our religion — they can't do that. 
While a gendered difference in expectations also exists in Palestine and Jordan, boys there are generally held to a higher standard of behavior than in the US, by extended family, community, and the society at large. The boundaries or red lines that were mainly enforced on females in the US also encompass males in Palestine and Jordan, although breaches by males are tolerated to a much higher degree than those by females. Thus, Mohammed said, "Maybe I would not have listened to my mom in the States cause I would have looked at others doing everything wrong and copied them." In Palestine he developed a stronger personal sense of right and wrong and he appeared to appreciate it. He concluded that Palestine is "the right place to live... a good society." In Palestine "there are people to tell me what - like my relatives and cousins they tell me what's right from wrong. In America, maybe there's nobody except my mom and dad. Maybe I would have not listened to them".

A second reason that might explain why boys overwhelmingly said they learned more about their religion in Palestine and Jordan than girls is related to mosques, which are much more conveniently located than in the US and are generally male-only places. Boys are not only welcomed in the many neighborhood mosques in Palestine and Jordan, they are by their own accounts highly encouraged to pray in them. This interaction of proximity and gendered space means that boys are far more likely than girls to be placed in situations where knowing how to perform prayer rituals and recite Qur'an matter, circumstances where they would need to learn more than they knew coming in. Largely excluded from mosques, girls do not face this type of religious ritual performance challenge. Their challenges are much more likely to come with regard to matters of public behavior, dress, and manners, which, as noted above, are behaviors for which they tended to have received training in the US. Finally, one cannot help but think that freedom to be a Muslim male, without the associated negative stereotypes found in the US, and freedom to pray publicly without invoking stares or slander, contribute to a subjectivity that boys would feel good about. In multiple gendered ways, being Muslim in Palestine and Jordan is very different from being Muslim in the US.

\subsection{Learning Islam in High School: Palestine and Jordan}

Youth interviewed for this study were juniors and seniors attending high schools in Palestine and Jordan where the Islamic religion is taught as a class [din]. Religion courses were usually mandatory, except that some private schools exempt English language dominant speakers from religion courses if they are taught only in Arabic. The majority of youth attended private schools that teach in the English language (even if they were raised in Brazil or Puerto Rico), although some offered both an English and Arabic track of instruction, because their Arabic was not proficient enough for public schools or private Arabic language schools. Some, however, attended local public schools or private schools with Arabic language instruction because either schools with English language instruction were far away from their homes or because their parents choose to enroll them in Arabic speaking schools, despite the fact that their Arabic was not at the high school level [most youth said they were at the 6th grade level]. Christians were also interviewed in this study, although they were a proportionately smaller group. The schools they attended offered din courses in both Christianity and Islam. 
Only a handful of youth said that religion courses at school played a significant role in furthering their knowledge about Islam and those who did so tended to have had little formal religious instruction at any prior time in their lives. For example, high school religion classes in Jordan were Samira's first formal religious learning opportunity. She grew up in Texas and learned how to pray and fast from her parents. The closest mosque was in Fort Worth, an hour and a half drive away, so they went there only on Muslim holidays.

It was my first time actually learning about my religion because they gave religion classes. It was part of the curriculum; it wasn't anything extra. So I learned a lot from that, I learned how to read and write Arabic, so I was actually able to read the Qur'an in Arabic. Um the hijab, I just recently started wearing it. I've only been wearing it for two years now. I don't know as much as I should know, but you know, I'm still learning. But here it helped a lot. I wouldn't have learned that much over there as I have here. [So, you learned it mostly in school?] Yes.

A few others mentioned religion classes at school as a source of learning Islam, but they coupled it with a string of influences, such as extended family, community, and mosques (boys only), suggesting that it was not a strong contributor to religious learning on its own.

Nayef from Amman grew up in New Jersey and said he did not know much about Islam before moving to Jordan. While he spoke about his religion class (in a relatively liberal school) in positive ways, it was only after he mentioned his parents and mosques, and then being prompted:

I didn't know anything before, like, about Islam, what's haram and what's halal. But now I do. [Where are you learning?] My parents, and two mosques, like... I'm more familiar with Islam, and I can read Qur'an really good now so, it's better. [And you study it in school too, right?] Yeah, only in religion class. They give us the sura, like, and they translate it to English so you can understand it, but you have to memorize the Arabic too. [Do you talk about it?] Yeah we do talk about, like class discussions a lot.... here we're free, like we-'cause we have some, we have two atheists in the school. Yeah, so like, we're free to talk about it, like, 'cause we had a debate, Darwin theory against creationists, and, so she discussed with us evolutionists and how it's wrong and stuff. Yeah.

Similarly, Mohammed, who was quoted earlier as feeling vulnerable to social risks in the US, credited his family, the mosque, and religion classes. In Palestine he is 'Memorizing the Qur'an more. Learning about din. Going to the mosque a lot, almost like every day. And learning din in our school".

Muna grew up in Chicago, where she said she learned the "basics": how to pray, fast, and wear hijab. She was now living in Turmos Ayya (Palestine), attending a local, Arabic language public school. She credits school and her family with helping her understand the reasons she should pray, fast, and dress in certain ways. Indeed, understanding why Muslims practice their faith as they do was important to many youth, mostly girls, who wanted to know the meaning behind what appeared to be routinized behavior.

[So has being here helped you understand religion better?] Yes, it did. Over there they told me the basics, the simple basics. I learned at home how to pray, how to fast in Ramadan, how to wear the scarf. But I don't know why, why to wear jelbab, mandeel, I mean hijab, when the right time comes; I never knew 
why. Why I should pray, how I should fast, etc. Here they told me why, and how a girl should behave in Islam. [So, you learned that in school?] Yes, here and at home.

Dalal from Ramallah grew up in New Jersey and was one of the very few who said they enjoyed religion classes. She said she always thought of herself as a "Muslim first", yet she credits moving to Palestine with dramatically changing her experience of religion.

I moved here in 2006, by 2007-I moved here Fall of 2006, by Ramadan of 2007 I had started praying, cause and you know when I was in America I thought 'Oh, praying is just, you know you don't have to do it' but I didn't realize it was, I mean, it is, you know it's a must. You know? And I want to pray. I wanted to always pray. So I finally learned that and I finally understood what religion is, you know. It's so beyond praying and fasting and this and that-you know? And uh I became very proud. I started enjoying religion classes a lot. So now I feel like um I understand the religion much more-

The above quotes express the points of view of the small number of youth who had positive things to say about religion classes at school. Far more common were criticisms of these courses. Indeed, many students elected to be interviewed during din class because they said they found it boring or could not understand the Arabic. Study data point fairly solidly to the conclusion that religion classes at school did not enhance religious knowledge or understanding for the overwhelming majority of these youth. For some they were a turn off because they stressed memorization, rules, and history, while allowing for little questioning and discussion. These critiques are similar to the ways in which they described weekend religion classes in the US. Hasheema grew up in Michigan and attended weekend religion classes, but said she did not really learn much from them. Although there were two mosques near their home, she only went to a mosque on the Eid. Now living outside of Ramallah, she said, "I'm a better Muslim here for sure." Yet when asked about her current religion classes at school, she said they teach "stuff that doesn't even matter anymore".

Yeah, we take...yeah, but we learn things that aren't really like, like we'll learn about stuff that doesn't even matter anymore. Like history more so than religion. And we'll learn about, like, like now we're taking something called zaqat, like giving money to the poor. And it's really, it's like 'If you have thirty cows you have to give a sheep' or something...it's like, what does that have to do with...I'm never gonna need that, so, yeah.

Fadwa from Amman said simply "it's just those details, like, you have to memorize".

Miriam, who was born and raised in Atlanta and now lives in Ramallah, said religion classes are not "enhancing critical abilities":

We're studying religion in school, yeah, but I don't feel like...it, all they do is just give you rules, this is what you can't do, this is what you can do. Abide by them. I don't feel that they're enhancing our critical abilities of dealing with situations, or, it's just more like of giving you just this guidebook with strict rules, and just following them. That, I don't think that's what-[So you're not studying the Qur'an?] We-we memorize the Quran, but we're not studying the Quran.

Appeals to a type of piety based in mechanical conformity did not resonate for many of these young Muslims, especially girls, who wanted a deeper sense of meaning, an understanding of why 
Muslims believe and act as they do. Boys, on the other hand, rarely spoke of a quest for deeper meaning. Instead, they tended to discuss the joys of praying and going to the mosque or to be broadly critical of the Muslim society they found.

A few youth said that religious instruction was biased by cultural interpretations. Abla, who grew up in New Jersey and now lives in Amman, said her religious education began in Jordan. She described her father as a borderline atheist and her mother as non-practicing. She said that religion classes "don't really go into the spiritual like side" and "they don't really care about like having you like really understand or enjoy your learning, they just want you to learn the material and that's it". She described her male religion teachers as biased.

Yeah like sometimes you can just like see a bit of like bias like from teachers, because sometimes Islam is kind of like more, like leans more toward the guys, and like more privileges for them, and like once you have a male religion teacher, like it's supposed to be between, equality between the sexes, but the males over here in the society, like, they take their own liberties in like interpreting it as how they want it to be, where they have like more dominance, so once, so there are some things that when you take it, and then they're talking about the role of the woman, how she has to stay at home, she can't leave without asking her husband. [They say that in religion class?] Yeah it's not in the Qur'an but it's like, there were some questions, and then we take a lesson about the roles of each individual, and so like when it came to the woman, the teacher he like asked a question, he's like so what do you think about like the woman leaving the house without calling her husband? And then for me, it's, I'm ok with that, like you don't have to call him for everything, like I'm leaving the house, I'm getting in the car, but he said, no you have to call because like you have to know, so it depends on like who's teaching you it.

\subsection{Religious Growth}

Despite the nearly unanimous criticism of high school religion classes in Palestine and Jordan, $58 \%$ of the youth interviewed said that living in Palestine or Jordan did increase their religious knowledge and understanding. This group included those who said they learned nothing about Islam in the US, all but one of those who learned to be Muslim mainly from family members, about half of those who attended weekend religion classes at some point in their childhood, and one boy who attended a full-time Islamic school. For these youth, being surrounded by Muslims was key to their religious growth. They came to better understand Islam as a way of life and as a way of acting around others; they enjoyed sharing Muslim feasts and fasting communally. Boys especially appreciated the ease with which they could pray and attend mosque services, felt more commitment to a Muslim ethos [as moral and behavioral code], and generally more free to simply be Muslim. These youth derived a sense of completeness, freedom, and comfort from the ubiquity (Islam and Muslims are everywhere) and totality (the full Muslim experience) that contextualized social life as a Muslim in Palestine and Jordan, one that moves in concord with Muslim rituals, calendars, and sensibilities. It allowed for a social and psychological ease that accompanies feeling that one is a constituent part of the society instead of an outsider who must deal with the assumptions, expectations, and discrimination of others. The presence of large extended family, which was true for most but not all of these youth, added key reinforcement to being Muslim in multiple ways, as teachers, observers, reinforcers, disciplinarians, and communities with whom to share being 
Muslim. These communities of support and face-to-face relationships with other Muslims were sorely lacking for many of these youth in the US, an outcome of migration and settlement patterns.

\subsubsection{Feeling Ease, Free, and Complete}

Fadwa from Amman, who grew up in Houston, described the experience of being Muslim as one that feels "complete". Although she notes that it is the same Islam with the same rituals and feasts [eids], being surrounded by other Muslims and hearing the call to prayer [adhan] creates "a whole different feeling". That feeling propelled her to pray and read Qur'an.

Actually, being here, by itself, gave me a new, a new... I don't know, what would you call it. It's the same religion, same, same thing, same fasting in Ramadan, same eids and everything, but over here it's just, when you have all those people around you, most of them are Muslims...it's just, it's a whole different feeling. Like I hear the adhan over there, you know how the adhan... Yea, I started praying, and I'm reading Qur'an more. It's just, it's, it's a nice feeling- I don't know it's like, I felt, like, complete...

Husni from Ramallah, who grew up in Alabama learning about religion from his parents, also appreciated being surrounded by a community of Muslims who lived according to the same lunar-based schedule and celebrated feasts together. When speaking about fasting, Ramadan and the eids, he compares Palestine, where "everyone" is "used to what's going on" to the US, where fasting was perceived by those around him as abnormal, the rotations of the lunar calendar were confusing, and feasts were not really celebrations.

Here it's easier to be a Muslim. Cause like there's not really much trouble like you can, people are like are used to what you're doing. Like in Ramadan if you don't fast, everyone's not fasting, I mean everyone's fasting. But over there, if you fast everyone's like "what's going on, is he normal?" Like everything's changing. Cause Ramadan changes from time to time so they get confused. But here everyone is used to what's going on, and like on the Eid, everyone goes out and celebrates. Over there it's like a small Muslim community that goes out and celebrates and it's not as much as like really celebration, it's just being with each other at that time.

Ala' grew up in Virginia learning about Islam from his parents, a full time Islamic school until third grade, and then Sunday school. He now lives in Amman and acknowledges that "there were a lot of things I thought I knew, but I didn't know actually", signifying that his experience in Jordan has taught him substantially more about his religion. He described fasting during Ramadan while in the US as an outsider experience, sitting "in the library if I wanted, instead of sitting in the cafeteria, or if I wanted to hang out with my friends, I would still sit in the cafeteria with my friends and fast". In Jordan he said he actually feels Muslim, it's "regular" and he doesn't "stand out".

Here you actually feel being a Muslim-I mean it's like a common, common thing here. It's like regular that I'm Muslim. Over there it's like something that stands out.

Alia, who said she is more religious in Jordan and understands Islam better, spoke about a greater sense of freedom that comes from not having to deal with the expectations of non-Muslims. Growing up in Minneapolis learning religion from her parents and at weekend classes she felt external pressures to act in certain ways because she was Muslim. 
When you're in America, cause they expect you to be Muslim they have this mind in their head they expect you to be like wearing a scarf, and all like, like praying every five minutes and stuff, and they expect you to do this, and like that, but here it's like you're a Muslim, but it's a normal thing cause you're in a Muslim country, you're in a Arab country. Like it's more free to be a Muslim and people don't expect more out of you because you are Muslim.

Alia's perceptions of American expectations of Muslims mirror expectations held by quite a few Muslim American youth. Many had imagined that Muslims "back home" were unambiguously religiously observant, living their daily lives true to the rituals, values, and ethos of Islam. They assumed that a social environment compatible to Islam produced better Muslims. As we will see below, many of the youth who had this expectation became disappointed by the Muslim realities they found, circumstances that did not inspire their religious development.

\subsubsection{Islam is a Way of Life}

Practicing Islam according to the Qur'an and Sunna [sayings of the Prophet] is intended to be a fully encompassing way of life that includes not only religious rituals but also ways of speaking, dressing, showing gratitude and humility, disciplining, and engaging in all sorts of social relationships. Jumana, who grew up in Florida, said she learned about these aspects of Islam living in Ramallah. In her view, Islam as practiced in the US follows a Christian model of attending services and praying, but that is only part of what Islam is.

Like it makes me more aware of what Islam is. It's not just a religion, it's a way of life and I never really understood that before. Like it has to do with the way you dress, the way you talk to your parents, the way you act. It's more than what I thought. It's not just like you go to church on Sunday like I was used to over there in America. It's like you go to a mosque every Friday and you pray every day and that's Islam. So here I'm like no, they taught me more.

\subsubsection{Praying and Fasting around like Others}

Boys who said they learned more about their religion in Palestine and Jordan were especially keen on mentioning the presence of mosques, fasting in the company of others doing the same, being able to pray during prayer times, and to pray anywhere. As noted earlier, mosques are places where men pray and listen to sermons; there are few mosques in Palestine and Jordan that accommodate women, who are expected to pray at home. Ala' described the Muslim American experience as one of concealment, as living in a place where a Muslim cannot pray openly, especially as compared to being able to pray "in the middle of the street".

Over here there are like mosques here- everywhere you're surrounded by Muslims, like especially when it comes to praying and fasting. I could do it in the middle of the street here and no one would - it would be regular. In America, it would be, it really stands out. Like if I would go and ask 50 people around me what religion they were, maybe only one person — not even one would be Muslim, so over there it's a lot more-its not secretive, but its more concealed.

Adnan, who grew up in Alabama and learned about Islam mostly from his parents, also felt that being able to pray anywhere without attracting stares made being Muslim easier in Jordan. 
Being a Muslim is easier in Jordan cuz like you can pray anywhere. I mean like nobody will look at you but like in the States if you're in the mall or somewhere and its time to pray you have to go somewhere, everybody starts looking at you. But here it's easier.

Not all of the youth living in Jordan or Palestine would agree with him, but Ala' said he really liked the social life in Amman, which includes family, neighbors, and the way that religious practice is seamlessly woven into life due to the close proximity of the mosque.

See in America, great school, but not so great social life. Here, poor school, but great social life. So basically if the school was here great and the social life was great, it would be the perfect lifestyle. [So what makes it great?] I mean cause the family. We have family right here and I have another aunt in Marj il Hamam and we always sit with them, hang out, dinners. Also the religion. I have a mosque two minutes away from the house. I go there, pray, come back. We're friends with our neighbors. The friends here I can easily go out and have fun and we all live next to each other and stuff.

Sameeh grew up in a Chicago suburb that had only two Arab families and now lives in a village outside of Ramallah. In the US he learned about Islam from his parents and went to a mosque "occasionally, maybe twice a year ... because there's not that many Fridays we get off." Even then, he said "we would just pray and then leave... I never really saw any Arabs or anything." Like Ala', he compares fasting in Palestine, where everyone is "doing it", to fasting in the US, where one must sit in the school lunchroom while everyone else is eating. Being in Palestine has helped him understand his religion more because practicing Muslims surround him. He highlights his ability to go to the mosque, listen to the sermons, and pray during class time, experiences he did not have in the United States.

Because $90 \%$ of the people here are Muslim compared to America, where I think it's like 1\% are Muslim. I'm not sure. It's something like that. It's under 5\% that's for sure. So going from where everyone around is Muslim and practicing the same thing. Ramadan and fasting month is easier cause everyone is doing it compared to when I used to sit at lunch and everyone is eating. So, and you learn more cause you go to the mosque more, you hear speeches, you learn a lot from the people around you because they're all religious and they hear things compared to just learning things from my parents and yeah. You learn a lot. Yeah I learned more, but I also practice my religion more here because in America I didn't really get up to go and pray in class, but over here it's 'adi. It's normal.

Narratives about praying and going to mosques were largely male accounts. I cannot help but think that their importance to these young men is due not only to the social fact that worshipping in mosques and praying in public are male only activities. I also believe that simply being able to engage in these activities freely is a liberating experience because being male and Muslim in the US is a stigmatized identity and they know it. Although young, most of the teenagers I interviewed reported experiencing some type of hate speech, anti-Muslim joke, or discrimination while in the US. While these events did not dominate their memories of growing up in the US, they certainly informed their sense of being different and being part of a religious faith that is looked down upon. Growing up in American society, it is hard to imagine that these youth were not exposed to the images of Muslim men praying that were contextualized in a way that sparked fear in so many 
Americans. In combination with their significant isolation from many other Muslims, one can imagine their unease with being practicing Muslims.

Yara's story is unusual for a girl because she speaks of praying in a mosque. Yara was living in a village near Bir Zeit (Palestine) and was raised in Palestine, Cleveland, and Tallahassee. She went back and forth between Palestine and the United States throughout her childhood depending upon conditions in Palestine (Israeli military activity, schools closures) and the family's desire to stay together (her Palestinian father, born outside of Palestine, has been unable to acquire entry to or residency in Palestine from the Israeli authorities). Her school in Palestine does not require that she take religion class because it is an Arabic subject, so she learns at home from her mom, which reminds her of the memorization of Qur'an she did in Saturday school in Florida "cause they don't want us to like forget". She describes the mosque in Tallahassee as being a "run down" place that nobody cares about, especially in comparison to Christian churches. Palestine is a better experience for her as a Muslim because she fits in better in a society where there is "prayer everywhere".

I mean it's hard because ... it's so like uncared for. Like you just go and you see all these gorgeous churches, and all these like Sunday schools, and all these benefits... And then you come to this mosque and it's like this little run-down place, because like it feels like nobody cares. And like teachers are just like volunteers, and it's not like something that it should be. It should be a mosque, a beautiful place to pray and worship, like the churches that they have there, but we don't have that. [So you come here, and ...?] I mean, I love it. Because it's just like prayer everywhere. It's like I feel like I fit in more. [Do you ever go to the mosque here?] I have, there's one in Surda. For prayers, and I go.

While boys who found their religious learning experience positive commonly credited being able to go to a mosque regularly, not being able to go to the mosque, because it was an activity largely restricted to males, was a source of discontent for many girls, and is one reason that overall, girls were less likely than boys to find their overseas experience helpful to their religious learning. For example, Fatma from Turmos Ayya, who grew up in Chicago, says she learned more about religion in Palestine from school, daily life, and her mother, but "here not a lot of girls go to the mosque, so my mother tells my brother to go to the mosque but not me". Fatma says that in Palestine a mosque "is just a mosque" but in the US "it is not just a mosque it is a place for all Islam people to gather", a point we will return to when we look at why some youth found their experience as Muslims better in the US.

\subsubsection{Being Responsible}

Finally, another reason a number of youth gave for learning more and understanding their religion better in Palestine and Jordan had to do with becoming a responsible Muslim, learning how to behave in a Muslim appropriate way. As might be expected due to upbringing patterns in the US that are gendered, this development was something only young men reported. Ayman from Beit Hanina credits being in Palestine with helping him to "grasp" his religion and be "responsible". The social environment encouraged him to start listening to his father. Growing up in Tampa, his father used to talk to him about religion, but he was never "into it". He went to the mosque only for eids and never attended weekend school. Now he reads Qur'an, prays, goes to the mosque on his own, and listens to the sheikh's qutba's (sermons). 
I really never, like my father used to tell us about it, like you should fast and stuff like that, but I really never, like, was into it until I came here. [When you came here how did that change?] I finally like grasped it, in, like I read the holy, I started readin' the holy book the Qur'an, I'd pray, listen to the sheikh and stuff like that. [Did you do that on your own? In school?] No I did it by myself. My dad like told me about it and then like I started to learn from him how to pray and stuff, and then like I started going by myself. [To a mosque?] To the mosque.

... Like um before I was lazy, to tell you the truth. But then now like uh once I came here and stuff, I'm more responsible. [Why?] Because like when my father used to tell me about my religion and stuff, like the fasts, I never used to do it back in the States. And over here like I felt like, you know, stupid. I should listen to them and stuff like that. And now like Fridays I go to the mosque and pray, and then I pray by myself, I read the book and all that. [So being here helped you in your understanding of your religion.] It helped me a lot, yeah.

Ayman's sentiments were echoed by a number of males, who said they did not fully listen to their parents or follow "the rules" for Muslims while living in the US. Recall Mohammed quoted above, who used to listen to his mother tell his sisters how to be good Muslims. He said it was better for a Muslim to be raised in Palestine than in the US because "here, maybe there are people to tell me what-like my relatives and cousins, they tell me what's right from wrong". The same was true for Iyad from Turmos Ayya, Palestine. Iyad grew up in California and said he knew nothing about his religion before coming to Palestine. In Palestine he learned the social and behavioral boundaries set by his religion.

Way better, like over there I know that I am Muslim, but I don't know the stuff we can do and we the stuff we can't do. Over here I know a lot of stuff.

Significant differences in behavioral expectations of Muslim boys and girls, such as existed in the US, were not done away with in Palestine and Jordan, but they were substantially lessened. Muslim girls were generally well prepared for the rules of comportment that governed the social environment they moved to while boys had much to learn. Corresponding to these heightened behavioral expectations on boys, as well as greater freedom to be Muslim in public space and a plentitude of mosques in which to pray, boys were far more likely than girls to say that their knowledge and understanding of Islam increased in Palestine and Jordan. Still, many girls derived pleasure from the Muslim infused social setting, describing a sense of ease and completeness about being Muslim that enhanced their religious growth. And while the mixing of politics and religion was discussed mainly by those for whom it discouraged religiosity, Hadeel, who was raised in Philadelphia and lived in a village outside of Ramallah, said she learned more about her religion in the context of observing and feeling daily life under Israeli occupation.

Actually being here made me learn more about like religion. I knew a lot about religion, but being here seeing with my own eyes and feeling like...what people go through, like just seeing it, then hearing it, it's different. It is totally two different things. And when you sit and see what's going on, you would just sit and cry. Like literally. 


\subsection{Ambivalent and Negative Experiences of Religious Growth}

Forty two percent of the youth interviewed, including 14 girls and 8 boys, said they did not learn more about their religion while living in Muslim majority Palestine or Jordan: that living there did not contribute positively to their religious growth, that it contributed in both positive and negative ways, or that it was the same as living in the US. Nearly all of the youth who had attended full-time Islamic schools and about half of those who attended weekend Islamic classes in the US fall into this group. We have already discussed the fact that high school religion classes had little positive impact on religious development, yet neither were they cited as specific sources of disaffection. Like those who said living in Palestine or Jordan had increased their religious knowledge and understanding, those who were less positive also referred to the people, the culture, and religious institutions. However, where the former saw ease of being, freedom to pray, a concordant rhythm of life, and Muslim completeness, they saw regimentation, insincerity, lack of commitment, and a perceived inappropriate mixing of culture, politics and religion. Moreover, for those who had experienced it in the US, they missed the sense of community they had at mosques and Islamic schools, which was not duplicated overseas. For this group, their discontents were heavily informed by their moral imaginaries of what a society would be like when organized by and with people living according to a Muslim ethos; it did not live up to their expectations.

\subsubsection{Assumed Moral Geography of Islam}

Youth naturally brought with them on their sojourns assumptions they had developed in the US about Muslims and Muslim majority societies, just as they had constructed imaginaries of what life in an Arab country would be like [15]. One of these assumptions, held by many, was that all or most Muslims would practice Islam fully: pray five times per day, wear hijab, shun alcohol, pork, and dating - assumptions that mirror what a large number of non-Muslim Americans think. The continuums of practice they actually observed in Palestine and Jordan, from rigorous to imperfect to none, were dismaying. Kamilla, who grew up in Texas and California before living in Amman, describes her expectations and what she found:

And I remember coming here and I brought my prayer rug and my prayer clothes and I assumed every single person would be praying and nobody would drink. It was interesting because most people don't pray in our school here. Maybe its because were in high school, but not everyone prays. The majority — we only have three people who are covered.

She attended an elite private school in Jordan where being able to discuss such incongruities was helpful.

Most are not devout Muslims, but we could openly speak about it with no worry and I think that's a kind of comfort and that helped me build my self-esteem about being Arab—about being Muslim.

Sam, who attended a full-time Islamic school in Boston, said that "in America" people think that Muslims in Palestine are very religious [although it is not perfectly clear who he is referring to, he seems to mean US Palestinians], but when he got there he found that not to be the case. Instead, he believes that because of the pressures of the Israeli occupation many had "let go" of religion 
while others followed it to the exclusion of everything else. Neither of these extremes was satisfying to him.

The thing is in America they think that they're really religious here, everyone like takes a very important role in religion, we have Jerusalem, we go pray there all the time, blah blah blah, but that's not how it is here. People are really sick of like, sick of how things are here, and because of this they kind of, some of them let go of religion and fall apart. I feel like others, those who choose to follow religion, follow it so closely to the point where they forget everything else. They forget who they are, life, whatnot. And that kind of separates them from society.

\subsubsection{Lack of Sincerity}

The most commonly articulated criticism of those who were ambivalent or negative when asked whether living in Palestine and Jordan increased their religious understanding revolved around observations of the perceived un-Islamic or insincere behaviors of persons whose outward appearance suggested that they were believers. In their view, Muslims who pray or wear hijab should do so out of deep faith and not behave in ways that contradict this faith. This view was often expressed in a comparison to their perceptions of Muslims in the US, who they saw as persons serious about their religious faith, who prayed and conducted their daily lives according to Muslim values and a Muslim ethos, or as non-practicing Muslims. While the latter were not faithful to their religion, they did not pretend to be. These youth were, in other words, disturbed by what they saw as the insincere performance of Islam for public consumption.

Luqman grew up in Los Angeles, went to the mosque every Friday and attended Saturday school. He felt his religious education was better in the US than in Jordan because "in the US people who go to mosque have pure intentions. Here they go cuz have to". Lina, who attended a full-time Islamic school in the Detroit area before moving to Palestine, expressed dismay at girls wearing hijab and dating.

Even if it is an Islamic people over here, it is not Islamic. Muslim people over here are like two faces, you know. Anyone who wears the mendeel (hijab), I can guarantee, I can guarantee you, that more than $15 \%$ that they have boyfriends.

Mai, who lived in Los Angeles and Louisiana prior to Palestine, was bothered by the same phenomenon. She concluded that American Muslims were more religious than Palestinian Muslims.

I think people in America where I grew up, they were more religious. If they were religious they actually stuck to it, whereas here they are fake about it and they do it as for show for the balad [village], so they don't get a bad reputation. Cause I know girls that are hijabis and they're hooking up with guys in empty houses. That — stuff like that - you know and they're sitting here talking about religion and it's not. It's not like, in America when girls put it on, they leave it on. They don't go take it off when some dude walks by.

Sam, who grew up in Boston and attended a full-time Islamic school in his early years, came right out and said that he thinks men in his Palestinian village worship in mosques for show.

Over here, nobody cares about religion, in all honesty. Like for example in [my village] I feel like people 
go to the mosque on Fridays because they have to, or else their image will be bad in front of everyone else.

Sam said he was more religious in the US. He believes that Muslims are more religious in the US "because they're forced to be. Their community, um, if they're not religious then their community, they'll separate, they'll fall apart."

\subsubsection{US Muslims Hold onto Religion More Tightly}

Sam's thoughts were echoed by many others who found their overseas experience with religion unsatisfying. They felt that American Muslims cared more deeply about religion than Muslims in Palestine and Jordan; some saw them as conformists or performers lacking moral depth, while others saw them as persons who were less serious about faith. Using various ways to describe it, they attributed the American Muslim phenomenon to Muslim's social position as religious minorities. Khalil, who grew up in the Houston area before moving to Amman, tried to put it in context:

To tell you the truth, being a Muslim is always being a Muslim but basically of course this is what we try to understand... but sometimes there is bound to be a little bit of difference... sometimes. Not necessarily in the practicing or so... sometimes over there... lets say they're a bit more attached over there... I mean over here, we're attached as well but I mean a lot of times I find people...I don't know they really just don't care too much about it, but over there they really do and also at the same time when you're a Muslim you also get to blend a bit of your American culture into your Arabness and Muslim.

Diana, who grew up in Ohio, Georgia, and Florida before moving to the Jerusalem area, said being different is what encourages American Muslims to "hold on".

Over there because you're different you try to hold on to it and over here because khalas everybody is the same and in the United States you hold on to it tightly.

Aziza, who lived in Massachusetts before Amman and learned religion through family and 12 years of Sunday school, calls it "uniqueness" and recalls fondly the sense of community she had with Muslims in her area.

I was part of the youth group and stuff so we'd hold events and during the summer we'd have speakers come in and stuff, so I loved it. It was really good community. We don't have that here in Jordan because it's not like a unique thing to be a Muslim or anything, so there's no like core community cause it's everyone. So in the States like because we were a minority we formed like our own little community family. It was nice.

In her view, Muslims do not have community in Jordan because everyone is Muslim. Of course not everyone is in fact Muslim and Muslims in Jordan do have community, but it is generally not formed via religious institutions. However, for young Muslim boys and girls who grew up around other Muslims in the US, the mosque and the Islamic school, if one existed, were among their primary sources of community. 


\subsubsection{The Mosque is not a Community}

This disjuncture between the way the mosque functions in Palestine and Jordan and the way it functions in the US was disconcerting to many of the youth who said their experience in Palestine or Jordan did not enhance their religious understanding. Saif from Jerusalem, who grew up in New Mexico and went to a full time Islamic school for 8 years, said the mosque in Palestine is "just a mosque" a place to pray and then leave.

For example, the mosque, in America the mosque for me was a community, people would be going, talking. Here the mosque is just, it's a mosque, it's a place where you pray and then you leave. So I guess I really didn't learn much more about my religion here. I learned that um a lotta people, cause again a lotta people misinterpret religion and I guess a lack of connection between the mosque and you know people.

When we consider that the majority of boys who reported learning more about their religion in Palestine and Jordan also spoke highly about praying in a mosque, and that these also tended to be boys who had less consistent exposure to Islamic institutions in the US, we can probably safely conclude that those young men had not experienced the American variant of mosque as community. They thus did not have the same comparative referent that Saif, Sam, and Luqman had, which produced a very different perspective on mosques. Where they found comfort praying in a mosque, the latter found a kind of emptiness. Saif also felt his Islamic education in the US was "more defined" than in Palestine. Here we see another impact on perspective that flows from living in a community that has invested in its Muslim institutions.

You'd have books and people who taught and people who actually went to college just to study Islam and to be a sheikh or an imam and they would be teaching. Here I don't have that great of a connection with the mosque.

Muslim youth who said they were part of a Muslim community in the US, because they attended full-time Islamic schools, were regular members of a mosque congregation, and/or because they had many relatives living nearby, were more likely express this kind of dissatisfaction with what they saw as a lack of community among Muslims in Palestine and Jordan. Ali, who attended a full-time Islamic school in the Chicago area and lived near a mosque, said Ramadan and the Eid were better in the US, and this was mainly because religious events shared with lots of family.

Like in America, Eid was fun, we had all cousins and all my aunts, but over here we have only one uncle and one aunt we go see. Yeh, my family is there, I liked there, and Ramadan there. Say like the month of Ramadan, it felt more Islamic there like in Ramadan. Over here no one fasts in school, like no one knows anything, except some of them, but a high number don't fast.

Ali said he did not learn more about his religion in Palestine, but he did learn about his culture:

No I can't say that, but it helped me understand my culture, because I learned how to do things over there, how to do the prayer and fast. I still do them over here. 


\subsubsection{Islam and Culture are Mixed Together}

A number of youth spoke disapprovingly of the mixing of culture and religion. For example, when asked if being in Palestine helped her understand her religion better, Mai said:

No. I've always understood Islam. I know right from wrong. When I came here I hear people saying, "this is haram." This is haram and it's not, it's just 'ayb (culturally wrong). It's just what they look down on in the balad (village). So they're mixing culture and religion, which isn't—it doesn't make sense.

Sam said:

For example, when you don't talk to girls and what not, that has nothing to do with Islam here. It's more about culture and honor and what not than it is about Islam and religion.

Awareness of the mixing of culture and religion is common to adult second generation Muslims who were raised in the US within a community of Muslims [16]. As they search for commonality with Muslims in their schools and mosques whose parents have different national origins than theirs, they look to shed the cultural practices that separate them from each other and find the authentic Islam that binds them. Yang and Ebaugh ([6], p. 280) found this pattern more generally among second-generation Americans from many religious traditions, who "return to theological foundations ... because they must bridge differences of culture and ethnic origin (internal pluralism) among co-religionists and because the authority of a religion that is based simply on tradition loses its power." It is too simple to say that this type of observation emerges only from a transnational perspective, because there are Muslim movements within the Muslim-majority world also fostering such a return. However in the case of these youth, because they said they did not learn more about Islam in Palestine and Jordan, this perspective is likely to be an outcome of earlier experiences with in the US.

\subsubsection{It's Political}

A few of the youth in Palestine, all males, were critical of the political meaning embedded in practicing Islam. Sam said his classmates discouraged him from practicing his religion, ridiculing him by saying "you're not Hamas." He became less religious in Palestine due to such peer pressure.

I feel like over here I've kind of become less religious, in a sense, than I was in America. Cause in America you have your friends who are very religious, they influence you, over here I feel like people are like "what are you doing? Don't do that. You're not like Hamas. You don't need to do that." [Like do what?] Pray, go to memorize Qur'an, whatnot. And like I'm free to do what I want, you know what I mean? So I guess I've become less religious when I moved here. And that's because of the people around me.

\section{Discussion and Conclusions}

These data show that learning to be Muslim transnationally is not the simple linear process that many, including parents and youth, had expected it to be. Rather than learning more deeply about Islam upon moving from a Muslim minority social context to a Muslim majority one, adolescent Muslims learned about Islam differently. By this I mean that they experienced rhythms of life, 
ways of practice, religious institutions, forms of community, and gendered expectations rooted in Islam that were different from those they knew in the US. Some found that these social features enhanced their understanding of Islam while others did not. Youth brought to their experiences in Palestine and Jordan an interpretive frame informed by their experiences of being Muslim within the United States, and these varied widely. Some were part of vibrant communities hosting mosques, youth groups, well-developed weekend classes, and full-time Islamic schools. Others intersected with fellow Muslims outside of the family only sporadically, because other Muslim families, mosques, and weekend religion classes were located some distance away. In between points on a continuum of Muslim American experiences include places where mosques and weekend classes were nearby but lacked the quality of investment, development, and staffing found in vibrant Muslim American communities. What they knew about Islam and how they felt being Muslim in the United States informed their receptivity to a different way of being Muslim, in a place where being Muslim is normative but also imperfect.

Muslim youth growing up in Muslim minority contexts develop moral imaginings of what Islam looks like in its geographic home [9]. Parents, relatives, religion teachers, friends, and a range of media sources inform these constructions of what "we" do and how "we" live. Their interpretations of later engagements with "authentic Islam" are shaped by these expectations. Youth who expected and perhaps desired a geography of full observance and free-willed sincerity were often disappointed by the more complex and flawed realities they found on the ground. Observations of non-practicing Muslims, perceptions of men attending mosques for social approval and hijab-wearing women acting improperly, and a conduct of social relations not always infused with charity and humility, bothered them deeply. Youth perplexed by what they saw as regimented conformity lacking spiritual depth thought American Muslims were more sincere, practicing out of choice and a deep commitment to their faith. They inferred that piety should be a conscious decision and not have the appearance of a mechanical act (cf. [17]). Many, however, found joy and comfort in the freedom to be Muslim, anywhere, anytime, in the syncopation of religion and daily life, in learning Islam as a way of life more deeply, and in sharing expressions of faith and religious holidays with so many others. Youth who felt this way said they understood Islam better because of these experiences. These realities co-exist in Palestine and Jordan, subject only to the different interpretations and emphases given to them by young Muslims.

Girls had different experiences of being Muslim than boys, both in the US and in Palestine and Jordan. In the US, parents placed more effort on raising their daughters to know Muslim values and "the rules" of proper Muslim decorum, including modesty, ways of carrying oneself, how to relate to male and female strangers, and showing respect for others. They buttressed these teachings with notions of difference from other Americans and by setting behavioral boundaries. While parents tried to inculcate these ideas into their sons, monitoring and enforcement was often weak. Girls were far more likely than boys to say that they did not learn more about Islam in Palestine or Jordan, that it was the same, or that it was both positive and negative. One main reason for this gendered difference is because they were already well prepared for living in a Muslim majority society, in matters of dress, behavior, values, and public decorum. Boys, however, found that in Jordan and Palestine people had higher expectations of them with regard to following the rules. While boys still had wider latitudes in behavior than girls, the differences were less extreme and 
they found that they had to change. In addition, because girls were largely excluded from religious institutions in Palestine and Jordan, their abilities to properly engage in ritualized actions such as praying, reciting Qur'an, and comprehending religious sermons were put to the test publicly less often than boys. Boys had to perform ablutions and prayers in front of those for whom these were almost natural activities and recite Qur'an and listen to sermons among others whose command of Arabic was far superior. In lieu of engaging in communal or public prayer, the public performance of an appropriate Muslim repertoire of behavior had enhanced religious significance for girls. It is no surprise then that girls who said their understanding of religion grew spoke about cognitive matters such as grasping the meaning behind why Muslims value and do what they do, while boys spoke mainly about ritual matters, such as going to mosques and praying in public, practices out of reach and even stigmatized for many boys in the US and out of reach for girls in Palestine and Jordan.

This study shows that for youth the transnational experience of being Muslim plays out in complex ways, very much dependent on how they experienced being Muslim while growing up in the US. The more satisfying the US experience, especially for boys, the more disappointing the one in Palestine and Jordan, not because it was inherently flawed, although they may have interpreted it in this way, but largely because it was different. Youth who grew up among a vibrant community of Muslims in the US, in which they were regular members of a mosque congregation, where they may have also attended a full time Islamic school and had extended family was close by, tended to describe their American experience positively. While in Palestine or Jordan, they interpreted their experiences with religion from this perspective and found them lacking, especially because mosques did not play the community role that they were used to. Boys for whom being Muslim in the US was a largely isolating experience, who spoke of fasting alone in the lunch room and having only sporadic contact with other Muslims, found community in Palestine and Jordan through family and mosques, and comfort in being Muslim, signified by the freedom to pray anywhere without stares. Both outcomes highlight the importance of community and solidarity to producing a positive and meaningful religious experience, which I think has heightened importance for Muslim men who have lived in places where their identities are stigmatized.

This article examined the processes of learning religion as described by Muslim American youth who lived in two countries before they reached the age of 18 , one in which they were a religious minority and another in which they were part of the majority group. They were brought to the latter by their parents, who wanted them to understand their culture, language, and religion better. The data show that although the different contexts matter for some aspects of being Muslim, living in a place where one is part of the dominant religious culture does not necessarily make for a deeper experience of religion. Living in a society where daily life is scheduled around your religious calendar, celebrations, and rituals and where you can practice your faith freely without stares, assumptions, or discrimination provides a personal sense of comfort and ease. Yet these factors alone are not sufficient to import a better understanding of religious faith. For some, they are counter-balanced by a seeming mechanical conformity and ritualism, sometimes perceived as disingenuous. What seemed to matter more than objective features of the macro social context was the type of experience with being Muslim each youth brought into the situation, because it was these experiences that informed their subjective interpretations of what it means to be Muslim. 


\section{Conflicts of Interest}

The author declares no conflict of interest.

\section{References}

1. Jerry Park, and Elaine Ecklund. "Negotiating Continuity: Family and Religious Socialization for Second-Generation Asian Americans." The Sociological Quarterly 48 (2007): 93-118.

2. Wan-Ning Bao, Les Whitbeck, Danny Hoyt, and Rand Conger. "Perceived Parental Acceptance as Moderator of Religious Transmission among Adolescent Boys and Girls." Journal of Marriage and the Family 61 (1999): 362-74.

3. Penny Edgell. Religion and Family in a Changing Society. Princeton: Princeton University Press, 2005.

4. "Interview with Penny Edgell. 2005b." Available online: http://www.pbs.org/wnet/ religionandethics/2005/10/28/october-28-2005-penny-edgell-extended-interview/11499/ (accessed on 28 October 2005).

5. Stephen R. Warner, and Judith G. Wittner. Gatherings in Diaspora: Religious Communities and the New Immigration. Philadelphia: Temple University Press, 1998.

6. Helen Rose Ebaugh, and Janet Saltzman Chafetz. Religion and the New Immigrants: Continuities and Adaptations in Immigrant Congregations. New York: AltaMira Press, 2000.

7. Fenngang Yang, and Helen Rose Ebaugh. "Transformations in New Immigrant Religions and Their Global Implications." American Sociological Review 66 (2001): 269-88.

8. Prima Kurien. “We Are Better Hindus Here': Religion and Ethnicity among Indian Americans." In Religions in Asian America: Building Faith Communities. Edited by Pyong Gap Min and Jung Ha Kim. Walnut Creek: AltaMira Press, 2002, 99-120.

9. Zareena Grewal. Islam is a Foreign Country: American Muslims and the Global Crisis of Authority. New York: NYU Press, 2013.

10. Edward Curtis IV. "Transnational Muslim Americans: Four Women in Jordan." Marburg Journal of Religion 17 (2013): 1-18.

11. Michael Smith. Mexican New York: Transnational Lives of New Immigrants. Berkeley: University of California Press, 2006.

12. Christian Smith. Soul Searching. New York: Oxford University Press, 2005.

13. Diana Eck. A New Religious America. New York: Harper One, 2001.

14. Ihsan Bagby. The American Mosque 2011. Washington: Council on American Islamic Relations, January 2012. http://faithcommunitiestoday.org/sites/ faithcommunitiestoday.org/files/The\%20American\%20Mosque\%202011\%20web.pdf.

15. Louise Cainkar. "Homeland Imaginings among Diasporic Palestinian American Youth." In PoCoPages: Diasporas and Cultures of Mobilities. Edited by Judith Misrahi-Barak and Claudine Raynaud. Montpelier: Presses Universitaires de la Méditerranée, 2014.

16. Louise Cainkar. "Islamic Revival Among Second-Generation Arab Americans: The American Experience and Globalization Intersect." Bulletin of the Royal Institute for Inter-Faith Studies 6 (2014): 99-120.

17. Saba Mahmood. The Politics of Piety. Princeton: Princeton University Press, 2004. 


\title{
Post-9/11: Making Islam an American Religion
}

\author{
Yvonne Yazbeck Haddad and Nazir Nader Harb
}

\begin{abstract}
This article explores several key events in the last 12 years that led to periods of heightened suspicion about Islam and Muslims in the United States. It provides a brief overview of the rise of anti-Muslim and anti-Islam sentiment known as "Islamophobia", and it investigates claims that American Muslims cannot be trusted to be loyal to the United States because of their religion. This research examines American Muslim perspectives on national security discourse regarding terrorism and radicalization, both domestic and foreign, after 9/11. The article argues that it is important to highlight developments, both progressive and conservative, in Muslim communities in the United States over the last 12 years that belie suspicions of widespread anti-American sentiment among Muslims or questions about the loyalty of American Muslims. The article concludes with a discussion of important shifts from a Muslim identity politics that disassociated from American identity and 'American exceptionalism' to a position of integration and cultural assimilation.
\end{abstract}

Reprinted from Religions. Cite as: Haddad, Y.Y.; Harb, N.N. "Post-9/11: Making Islam an American Religion.” Religions 5 (2014): 477-501.

\section{Overview: Increased Islamophobia}

The attacks of 9/11 have been analyzed in various ways as constituting a point of transformation in American history after which "everything had changed"-including perceptions about the world and one's surroundings, and relation to and awareness of a broader political geography ([1]; [2], p. 180; [3]). A major marker of this post-9/11 paradigm shift was, and for some remains, religion, including levels of religiosity and what it means to hold a particular religious view or identity in the United States. Some American Muslims reported that 9/11 introduced an era of intensified suspicion about Islam and Muslims on the part of non-Muslim neighbors, colleagues, classmates, and friends. Others reported that the initial suspicion of law enforcement officials, elected politicians, and homeland security agents over the last 12 years has developed into systematic, and sometimes extralegal, scrutiny of Muslims and Muslim communities [1,4]. ${ }^{1}$ The increase in hostility toward Islam and Muslims by security officials appears to have a direct impact on the faith and practice of Islam in the U.S., including the interpretation of the tenets and scriptures of the faith, the formation of Muslim identity in America, and the emphasis on volunteerism and civic

1 For an overview of the codification of Islamophobic rules and policies designed to monitor American Muslims, see [5]. 
engagement. For many Muslims and those who study the religion, Islam in America since 9/11 has undergone significant transformations.

This article explores some of the key events that led to periods of heightened suspicion about Islam and Muslims in the United States in the last 12 years. It provides a brief overview of the rise of anti-Muslim and anti-Islam sentiment known as Islamophobia, and it critically examines the claims of those who promote legislation designed to marginalize American Muslims on the basis of their Islamic faith. The article addresses the perspectives of American Muslims who believe they are singled out in the national security discourse on terrorism and radicalization, both domestic and foreign. The authors take seriously the need to evaluate historical realities and shed light on developments, particularly among Muslim communities in the United States in the last 12 years, which might belie allegations of widespread anti-American sentiment among Muslims or questions about the loyalty of American Muslims.

In the last part of the article, we take up the epistemic shifts in relations among American Muslim communities since 9/11. Many American Muslims are embracing an authentically American identity inspired by and infused with modern and recognizably post-9/11 interpretations of mainstream Islamic orthodoxy and orthopraxy. They are increasingly choosing to integrate into American society through participation in and production of American culture in both civic engagement and in new, innovative ways such as art, filmmaking, political involvement, authorship, scholarship, and interfaith engagement. Advancements in Sunni-Shi'a engagement and collaboration are underway. We take note of how major Muslim organizations, such as the Islamic Society of North America (ISNA), have stayed at the forefront of Islamic reform. ISNA has maintained its relevance and its membership by capitalizing on and recognizing major trends in American Islam at its annual national convention.

We attempt to identify the major trends in American Islam as well as changes in the everyday activities of American Muslims after 9/11. ${ }^{2}$ We argue that Islam in America is continuing to change and be transformed in ways that sometimes coincide with the policy objectives of the U.S. government and national security officials.

Islamophobia (coined by the Runnymede Report to describe western proclivity to anti-Muslim sentiment) did not arise in a vacuum. Anti-Muslim and anti-Islam sentiment has a venerable history in Western culture. Since 9/11, a specific set of events helped to perpetuate the claims of the Islamophobia industry in the United States and Europe. While there are relevant contexts that have intensified Islamophobia in the United States, it is clear that they are exploited and exaggerated by individuals who are motivated by political considerations or are seeking self-enrichment and notoriety. The awareness of Islamophobia as a social problem in the United States and Western Europe was heightened in the academy with the publication of Edward Said's Orientalism [9]. While Said did not use the term 'Islamophobia', he laid the groundwork for a greater awareness of the phenomenon. This phenomenon has been exacerbated since 9/11 as revealed in the number of new publications on the topic and on Islam in America [10-20].

\footnotetext{
2 There is not space in this short article to discuss the transitions of Muslims in America over generations from being an immigrant society quite separate in some ways from the majority society to, especially after 9/11, integrating into the fabric of American society. For more on this, however, see [6-8].
} 
Although the term 'Islamophobia' is now widely accepted and used in academic as well as legal, political, and social contexts, it remains contested in certain discourses. As such, there are multiple definitions of Islamophobia. Richard Schaefer, writing for the Encyclopedia of Race, Ethnicity, and Society, dates the term back to the early 1990s and defines it as a "range of negative feelings toward Muslims and their religion, from generalized bigotry, intolerance, and prejudice on the one hand to a morbid dread and hatred on the other" that might "manifest itself in... discrimination against Muslims, social exclusion, verbal and physical harassment, hate crimes, attacks on mosques, and vilification of Islam in the media" $[21,22]$.

\section{American Muslims under Scrutiny}

While the whole world has heard of the tragic loss of life perpetuated by the $9 / 11$ attacks, relatively few outside of academia have paid attention to the impact of $9 / 11$ on the lives of the thousands of American Arabs and Muslims who were detained without warrant under the auspices of the USA PATRIOT Act. The authors of Arab Detroit 9/11: Life in the Terror Decade describe this context of reinvigorated prejudicial treatment of Arabs and Muslims in the United States. Focusing particularly on the Arabs and Muslims of Detroit, the authors describe the first decade after the attacks of $9 / 11$ as "post-9/11" — a "time/space in which they (American Arabs and Muslims) were linked to enemy Others and were expected to prove their loyalty to the nation-state in ways other Americans were not" ([23], p. 2). The book goes on to define the means by which the concept of a "target of opportunity" was re-appropriated by US national security officials as essentially a PR-friendly framework for engaging in thinly veiled institutional racism toward American Arabs and Muslims. This trope of Muslims as "enemies within" lingers. In September 2013, for example, Sid Roth, the founder of a Jewish Messianic movement that broadcasts Islamophobic messages, invited Erick Stakelbeck to speak about "stealth Jihad", which he identified as "the enemy (Muslim) in a business suit", and expounded the theory that the Muslim Brotherhood is working to destroy America and Europe. In the months after 9/11, FBI officials in Detroit, home to hundreds of thousands of Arabs and Muslims arrested, convicted, detained, and deported thousands of individuals due to their national origin or religion [24]. This narrative has also gained traction in Europe, Canada, and other countries [25-30].

Overwhelmingly, the targets of these national security procedures to gather intelligence have been American Muslims and their communities across the country. The March 2013 report Mapping Muslims: NYPD Spying and Its Impact on American Muslims, produced by the Muslim American Civil Liberties Coalition, corroborates the problem of law enforcement officials singling out American Muslims as national security threats despite evidence that demonstrates a more serious threat from white supremacists and other far-right groups. According to the report, New York police "marginalized and criminalized a broad segment of American Muslims" based on their religious identity $[31,32]$. $^{3}$

As Arabs and Muslims in America increasingly experience the infringement of their civil rights and direct discrimination, questions of freedom of religion and the value of diversity or multiculturalism in the United States come into focus. Are Muslims the exception to America's history

3 For a comparative analysis, see [24]. 
of gradual integration of minorities into its social fabric? Do Muslims in America face the options of either change, or as one interviewee in Mapping Muslims put it: "decrease your Islam," or, failing that, treatment as an "enemy of freedom" and threat to national security ([32], p. 56)? If the answer to these questions is "yes", then it is necessary to define what is meant by "too much Islam" or by "bad Muslim" as opposed to "good Muslim."

Despite the passage of over 12 years since 9/11, American Muslims continue to face scrutiny and, in some cases, are subject to direct FBI surveillance due to the perceived contradiction between their religious and national identities - more bluntly, many cannot accept that the same person can be simultaneously a practicing Muslim and a good, loyal American. In the national media and many Washington offices, American Arabs and Muslims are still portrayed as "potential threats to American security," but also, vexingly, as potential assets as seen during the Bush administration ([23], p. 88). ${ }^{4}$ The Obama administration has neither reversed nor challenged its predecessor's policies and has also taken up the "campaign to reshape the Middle East and fight the War on Terror" while enlisting the aid of American Muslims [34,35]. In an October 2012 article for The Guardian, Glenn Greenwald argues that the Obama administration has been working to "fully institutionalize - to make officially permanent - the most extremist powers it has exercised in the name of the war on terror" [36].

\section{How the Killing of bin Laden Increased Islamophobia}

Although Islamophobia is partially the result of unquestioned assumptions about Muslims, it is also clear that specific events occurred in the West after 9/11 that helped to reconstitute Americans' latent fear of Muslims and Islam and likely further intensified anti-Muslim sentiment in the U.S. and Europe. These include, among others, the 2004 murder of Theo Van Gogh in the Netherlands, the 2004 Madrid train bombing, the 2005 attacks on London's train system, and the release of a DVD titled Obsession: Radical Islam's War against the West [37,38]. The effect of these events was exacerbated by the 2006 controversy over the Danish cartoon defaming the Prophet and Pope Benedict's controversial lecture in Germany [39,40]. The 'Ground Zero Mosque' controversy in 2010 again exacerbated fear of Muslims in the West [41,42].

The "Arab Spring" in January 2011 and the killing of Osama bin Laden in May 2011 led some to believe that the Global War on Terror might be coming to an end and that perhaps Islamophobia was seeing its last days. ${ }^{5}$ Then two events re-enlivened suspicions across the United States about "homegrown Islamist terrorism," namely the attack on the American diplomatic mission in Benghazi, Libya on September 11, 2012, killing U.S. ambassador Christopher Stevens [44-48], and the Boston marathon bombing carried out by two brothers of Chechen Muslim origin on April 15, 2013. Many American Muslims believed that the death of bin Laden would usher in the beginning of the end of the Islamophobia they had faced in the prior decade. However, a 2011 survey conducted by the Ohio State University School of Communication, Cornell University's Survey Research Institute, and the University of New Hampshire Survey Center, suggested that many Americans' view of Islam and Muslims counter-intuitively deteriorated further following

\footnotetext{
4 For more on Washington's support of the NYPD's surveillance of American Muslims, see [33].

5 For an example of enduring Islamophobia, see [43].
} 
Obama's dramatic Sunday-night primetime announcement of the al-Qaeda leader's demise. ${ }^{6}$ It seemed that the killing of bin Laden, and perhaps the media's handling of the news, served to exacerbate negative attitudes toward and associations with Muslims.

The study found that while half of the participants believed American Muslims were "trustworthy" and "peaceful" before bin Laden was killed, only one-third maintained those attitudes post-bin Laden. Omar Sacirbey surmises that "the most troublesome finding was that these negative shifts had occurred among political liberals and moderates, a constituency that had been seen as the most sympathetic to Muslims after the 9/11 terrorist attacks." Specifically, the survey found that the proportion of political liberals who indicated that "Muslims make America more dangerous" increased from 8-24 percent after the media's coverage of bin Laden's death [48].

For non-Muslim Americans, the handling of bin Laden's death by the national media made them more apprehensive about becoming close friends with a Muslim-whereas $9 \%$ had expressed hesitance before his death, that figure rose to $20 \%$ some days afterward. In Portland, Maine, the day following bin Laden's death, someone vandalized a local mosque and spray-painted the message "Osama Today, Islam Tomorrow" on one of its walls. In Texas, a schoolteacher was suspended for saying to a 9-year-old Muslim girl in his algebra class, "I bet that you're grieving" [48].

\section{The Islamophobia Industry in America: Shaping and Contesting American Islam}

While the demonization of Islam has a long history in America, 9/11 is seen by many to have marked a new phase $[3,49]$. A veritable Islamophobia industry developed around the demonization of Islam. Publications such as Fear, Inc., a report by the Center for American Progress, the Council on American-Islamic Relations' (CAIR's) annual 2009-2010 and 2011-2012 Islamophobia Reports as well as its briefs and other documents, and The Islamophobia Industry by Nathan Lean identified a ring of "pseudo-scholars" and authors supported by a verifiable 40-million-dollar-a-year Islamophobia industry in the United States with an increasingly global reach. CAIR estimates that between 2008 and 2011, the industry made approximately 120 million dollars [50-52]. The industry is driven by neocon stars: Daniel Pipes, Robert Spencer, David Yerushalmi, Glenn Beck, Pamela Gellner, Paul Wolfowitz, David Horowitz, and Frank Gaffney as well as native informers Walid Shoebat, Walid Phares, Wafa Sultan, Ayaan Hirsi Ali, Ibn Warraq, Brigitte Gabriel, Tawfik Hamid, and Zuhdi Jasser. They have been prolific, producing and re-circulating false or exaggerated information about Islam and Muslims in order to gain lucrative speaking engagements and increase their influence among neocons in government [53].

Their lectures and publications promote the idea that there is a global Muslim conspiracy to take over the United States and impose "medieval Islamic law" on America [54-56]. They also demand that the government of the United States begins "religion building" [57] to help fashion a "moderate" Islam, which would essentially mean an Islam that is devoid of elements of praxis or articles of faith [58,59]. Some people have accused them of scare tactics in that any Muslim who prays and fasts is deemed to be either a terrorist or a potential terrorist who cannot be trusted. The

6 See [48] for a poll based on 500 interviews between April 7 and May 1 (when bin Laden was killed) and another 341 interviews between May 2 and May 24, reporting that "the number of respondents who said Muslims living in America 'increased the likelihood of a terrorist attack' rose from 27 percent before May 1 to 34 percent after." 
Islamophobia industry promoted the Park 51 attempt to stop New York Muslims from constructing an Islamic community center several blocks from "Ground Zero." Muslims saw that effort as a direct affront on their right to freedom of religion as American citizens [60].

The Islamophobia industry today is working to outlaw the Islamic ethical code, known as 'shariò', in every state in the country [61]. Since 9/11, some Republican legislators around the U.S. have convened congressional hearings to investigate whether Islam is a religion and have submitted proposals in over 32 states to legally ban shariò law [62,63]. The 2013 Boston marathon attack re-ignited Islam- and shari'a-phobia. As a result, American Muslims mourned the attack in Boston but also felt increasingly marginalized and targeted.

\section{The "Good Muslim, Bad Muslim" Effect}

Mahmood Mamdani may not have coined the phrase "good Muslim, bad Muslim," but his now-paradigmatic book, Good Muslim, Bad Muslim: America, the Cold War, and the Roots of Terror drew on the large body of literature and evidence that gained traction after 9/11 when government offices were actively seeking to define 'the enemy' in the Global War on Terror. Muslims were placed under the microscope [64,65]. While Mamdani's book did not receive as significant a response from the academic world as perhaps it could have, his research forms a definite contribution to the study of the policies that seek to identify two essential Muslim personality tropes in terms of national security: "good" and "bad" [66]. Mamdani's book ultimately gave rise to a flurry of other published books and articles about the efforts to brand Muslims as either 'good' or 'bad'. His conception of the detrimental impact of a worldview-one that is quite common in Washington - that tends to subdivide all people into "moderns" and "premoderns" helps to constitute a fuller genealogy of the Islamophobic policies produced by lawmakers in the aftermath of $9 / 11$.

Mamdani constructs his critique of this dichotomy on the basis of the genocide of the Herero people in South West Africa in 1904 by the Germans and the Holocaust later that century perpetrated by Hitler's Third Reich regime. For Mamdani, the relevance to Islamophobia today is clear: both of these genocides, and indeed all genocides, begin with what he calls "race branding" ([66], p. 7). He notes that "( $\mathrm{t}$ )he link between the genocide of the Herero and the Holocaust was race branding, which was used not only to set a group apart as an enemy but also to annihilate it with an easy conscience" ([66], p. 7).

Analyst Peter Danchin, in his multiple installments on The Imminent Frame, an online blog featuring researchers of religion, secularism, and nationalism, spotlighted what may be the most conspicuous, and perhaps earliest, use of the "good Muslim, bad Muslim" dichotomy in an official narrative. His posts in the spring of 2010 were a response to the February 23 Chicago Council on Global Affairs Report titled, "Engaging Religious Communities Abroad: A New Imperative for U.S. Foreign Policy" [67]. Drawing on the work of Mamdani, Danchin's 2010 entry expands on the U.S. foreign policy implications of the modern-premodern paradigm that animates the hostility of the Chicago Council Report toward various political forms of Muslim identity. Danchin indicts the conflation of religion with power politics not only for its facile reductionism but also for its potency in legitimating state-sponsored surveillance of American Muslims, as well as violence against Muslims abroad in the name of the Global War on Terror. 
In this vein, Saba Mahmood in "Secularism, Hermeneutics, and Empire: The Politics of Islamic Reformation" has posited that since 9/11 the U.S. government, including politicians on both sides of the aisle, has worked to institutionalize secularism in Muslim societies "both as a political doctrine and as a political ethic" [68]. According to Mahmood, secularism in "contemporary American discourses on Islam" is "deeply shaped by U.S. security and foreign policy concerns in the Muslim world" ([68], p. 323). For Mahmood, "contrary to normative understanding of secularism today," the "force" of what she terms "secularity" in the U.S. government policy of reforming Islam "from within" is not in "neutralizing the space of politics from religion" but is rather in "producing a particular kind of religious subject who is compatible with the rationality and exercise of liberal political rule" ([68], pp. 323, 344).

The work of this policy over the last 12 years has led to constraints on the identity formation of American Muslims. For this small but diverse and largely un-integrated religious minority, Mahmood asserts that having to choose between "religious truth" and secularity "can only elicit an equally singular vision in response, one in which all shades of interpretive, moral, and ethical ambiguity must be leveled so as to salvage the dregs of what might have once constituted a tradition or a life-world" ([68], p. 326). In "Muslims and American Religious Pluralism", Yvonne Haddad similarly argued that post-9/11 government security measures that target American Muslims "have isolated Muslims and placed them in what one Muslim called a 'virtual internment" "where Muslim identity is politicized and regarded as a security threat rather than a religious identity that can co-exist with American identity [69].

The Chicago Report recommends that U.S. foreign policy ought to focus on attacking the premodern Muslims who are anti-Western, while acknowledging that "at the same time, American security crucially depends on more effective engagement with, and support for, the good Muslims, not only to save them from the extremists but also to create stable, peaceful, and cooperative partners in a strategically and geopolitically vital part of the world." This pragmatism in foreign policy is lost on American Muslims in the United States who feel marginalized and are frustrated by being treated as a constant 'enemy within' who pose a threat to national security at every turn [70].

\section{The National Security Agenda and its Double Discourse}

On June 13, 2007, the anti-Muslim hate group Society of Americans for National Existence (SANE), under the leadership of David Yerushalmi, unveiled the "Mapping Shari'a in America Project" that targeted some 2,300 Islamic institutions in the United States [71]. The project draws on the fear of some Americans that Muslims are attempting to "Islamify" the country by applying "shariò law" in US courts [72]. Yerushalmi designed the "Mapping Shariò" project to "collect information about America's... mosques and associated day schools, provide information to both law enforcement officials and the public, and test the proposition that Shariò amounts to a criminal conspiracy to overthrow the U.S. Government" [73]. SANE publications claim that Islamic centers in the United States have become hotbeds of extremist activity that "promote violence, terrorism and hatred against America, and violent jihad" [74]. In February 2007, SANE issued a policy paper that stated: "Whereas, adherence to Islam as a Muslim is prima facie evidence of an act in support of the overthrow of the US. Government through the abrogation, destruction, or violation of the US 
Constitution and the imposition of Shariò on the American People. . It shall be a felony punishable by 20 years in prison to knowingly act in furtherance of, or to support the, adherence to Islam" [75]. Yerushalmi has been quoted as saying: "Shariò is not merely speech, and it is certainly not religion as understood by the West... Rather, it is a political and ideological mandate to destroy the West. We believe that every act to teach, preach, and live according to traditional, historical, and authoritative Shari'a contributes to a criminal conspiracy to overthrow our government." Yerushalmi has offered a template to legislators in over 20 states that claims to sidestep constitutional objections to singling out Islam by avoiding explicit mention of the religion (not all states have used his template).

By the 1990s, American society could virtually be divided along two paradigmatic lines [76]. One boundary delineated the United States as a Judeo-Christian nation, which by implication excluded and marginalized members of other faith groups. Belonging to this category required serious cultural and religious sacrifices as well as, not accidentally, adopting an unwavering support for the State of Israel. This practically kept Arabs and Muslims on the outer fringes of acceptable American identity. Those outside the bounds of this paradigm operated on the assumptions of a second paradigm that promoted the United States as a nation that honors pluralism and celebrates diversity. This conception of pluralism that created space for Muslims made many Protestant evangelicals and supporters of Israel uncomfortable.

Muslims everywhere, once thought to be natural allies of the United States against the atheist Communists, were re-imagined during the 1990s. They were once again, as they were after the establishment of Israel and in the decades thereafter, depicted by some as enemies of freedom unfit for citizenship in the new American world. This depiction of Muslims as enemies facilitated the use of drones by President Obama [77]. Yasmin Alibhai Brown has pointed out that the drones have become an instrument by which to kill Muslims who in any way may have obstructed US interests abroad [78]. While claims of American exceptionalism have been on the decline, the argument is far from having been laid to rest. A 2011 article for Foreign Policy entitled "The Myth of American Exceptionalism," Stephen Walt advises that "if Americans want to be truly exceptional, they might start by viewing the whole idea of 'American exceptionalism' with a much more skeptical eye" [79].

In the 12 years since 9/11, Muslims in Western Europe and the United States have faced unprecedented and rising xenophobia and Islamophobia, at least in part as a consequence of the propaganda for multiple wars in Muslim majority countries. However, scholars such as Jack Shaheen, Tariq Modood, and Michael Suleiman, who focus on depictions of Muslims in the West and their treatment, argue that Islamophobia is an extension and manifestation of a more deeply-seated and visceral resentment that must be recognized as an intense and vitriolic form of racism and bigotry [80].

\section{Emergent Forms of American Islam}

American Muslims have responded to 9/11, Islamophobia, and changing attitudes about American identity within their own communities in many different ways. In 2010, Qasim Rashid, an American Muslim writer, in an article in the Religion section of The Huffington Post, responded to an e-mail he had received, which asked, "Are Muslims even allowed to be loyal to the United 
States?" [81]. Rashid's reply reflects the latest trend in American Muslim attitudes. "For a Muslim, loyalty to the United States is not simply lip service but a fundamental requirement of faith" because America recognizes "the equality of its citizens regardless of background, and champions a universal freedom of religion."

Others have also written more extensively about how Islam in America has shifted since 9/11 toward a more deeply integrated relationship with American society and identity [82]. In a 2004 Nawawi Foundation paper, "Islam and the Cultural Imperative," Umar Faruq Abd-Allah argues that American Muslims cannot "(safely) retreat from the task" of "(c)reating a sound Muslim American identity" [83]. Abd-Allah's paper contributes an intentionally Muslim voice to the discourse on Islam in America and to identity formation for American Muslims seeking a safe space in post-9/11 American society. Omid Safi's 2003 edited volume, Progressive Muslims: On Justice, Gender, and Pluralism, also stresses the need for Muslims in the West to find ways of better integrating their Muslim identities and interpretations of Islamic doctrines and practices with their societal and cultural settings [84].

The availability of Islamic literacy programs and Islam 101 sessions run by Muslim Student Associations on college campuses has proliferated nationwide in the last 12 years [85]. These events are meant to combat Islamophobia and present accurate information about Islam and Muslims to those most in need of a basic literacy in Islam and Muslim identity. Many of the conferences led by The Islamic Society of North America (ISNA), Islamic Relief, The Next Wave Muslim Initiative (NWMI), The Council on American-Islamic Relations (CAIR), The Muslim Political Action Committee (MPAC), and the Muslim Student Association (MSA) as well as certain United States government internship programs since 9/11 have focused on Muslim engagement with and participation in mainstream American society, politics, and culture [86].

The 50th ISNA annual conference in 2013, entitled "Envisioning a More Perfect Union: Building the Beloved Community," kicked off with a session on "Our History: The Story of American Muslims Through ISNA's Eyes" [87]. The organizers dedicated the second session of the conference to Rev. Dr. Martin Luther King Jr. in honor of the 50th anniversary of the "I Have a Dream" speech. The speakers included Imam Zaid Shakir and Azizah Al-Hibri, Yasmin Mogahed, Tariq Ramadan, and Yasir Qadhi [87,88]. Mogahed is known for her support of pluralism and pietistic approach to Islamic faith and practice in general [89].

Also at the conference was Abu Ammaar Yasir Qadhi Al Amreeki, an American Muslim writer and blogger on muslimmatters.org. He is Dean of Academic Affairs at the Al-Maghrib Institute, an Islamic educational institution [90]. Qadhi has written three books on shirk, that is, 'polytheism' or equating other deities with the one God of Islam, and has spoken publically about Jews and Christians being mushrikun, or polytheists, who are "filthy" in the eyes of God and whose lives and property are halal, or religiously lawful, for the taking until they testify to their belief in the one God of Islam [91].

The 2006 ISNA convention featured Pakistani speaker Farhat Hashmi, a controversial speaker who, like Qadhi, has a large following in the United States. Hashmi runs a school for girls in Pakistan with branches in Toronto and Houston [92]. The girls at the school must wear niqab, or a full-lengthy black garment that covers every part of a woman including eyes and hands. Hashmi is known for supporting the practice of polygyny in Islam and encourages Pakistani women to allow 
their husbands to marry multiple times [93]. Her following in Pakistan is mainly among middle and upper class women [94]. New Muslim groups may be challenging the previous stature of older, larger organizations like ISNA and ICNA or the International Institute of Islamic Thought (IIIT) [95]. The latter organization has responded by funding The Islamic Chaplaincy Program at Hartford Seminary. This is an effort to train Muslim chaplains in the United States. IIIT began funding for the creation of a core of American religious leadership who are knowledgeable about American religions and who could engage in interfaith dialogue as well as communicate comfortably with Muslim American youth [96].

\section{Reform and Gay Rights Muslim American Organizations}

What ISNA and ICNA are contending with are indigenous movements within Muslim American communities to create "reform" mosques and communities that reflect their changing values and politics [97]. The Washington, D.C. based Muslims for Progressive Values (MPV) group is gaining a following among the growing Muslim population in the D.C. metro area [98]. The group promotes women's empowerment and a "progressive shariah" guided by their philosophy of progressive Islamic humanism. MPV provides counseling services to same-sex couples and explains that it uses "traditional Islamic formulations of ijtihad, to derive clarity from Quran and authentic Sunnah," following the teachings of Imam Daayiee Abdullah [99]. Abdullah, an African-American and a graduate of Georgetown University, was born Sid Thompson in Detroit, Michigan and is an openly gay Muslim and widely recognized leader for gay rights in Islam. He uses his MPV website and the Al-Fatiha Foundation, as well as his connections with the Muslim Alliance for Sexual and Gender Diversity, the LGBT Muslim Retreat, Muslim Gay Men, and the mosque he directs, Masjid Nur Al-Isslaah, to combat Islamophobia and discrimination against homosexuals [100]. His MPV group started as a small group of American Muslims who met in a library and has now grown into a nation-wide movement with 12 chapters including Los Angeles, Philadelphia, and Atlanta [101]. While ISNA and ICNA organizers have yet to consider broaching the topic of gay rights in Islam or the status of women, MPV mosques have female Imams who lead mixed congregations in prayers where men and women stand side-by-side, and openly support same-sex marriages between Muslims and between Muslims and non-Muslims, including situations where a female Muslim marries outside the faith - a practice banned by traditional Muslims.

In a 2007 Huffington Post article about MPV, Mohamed Magid, ISNA president, was asked about the values of the MPV group. He was careful not to condemn the groups, saying "he welcomes a 'marketplace of ideas' competing within Islam" and emphasized that he has "no right to strip anyone of Islam who wants to be Muslim" ([101], p. 2). Still, he was firm that in his mosque only men lead prayer and he does not believe Islam "condones homosexuality". While the MPV group enjoys some popularity, only a very small segment of American Muslims support it and they have struggled in the past to maintain places of worship in the face of challenges and discrimination by more traditional Muslims.

Muslim reform groups in the United States were very marginal in the mainstream until the years following 9/11 [102]. Oftentimes, American Muslim reform movements enjoy some support for a short period and then fall out of favor with the community and shut their doors - defunct websites like islamicreform.org are testaments to the lingering resilience of traditional Islam and the 
hesitation of American Muslims to break from the past. However, reform movements coupled with gay rights advocacy organizations, such as the Al-Fatiha Foundation, established in 1997, and the Safra Project, created in 2001, have managed to stand the test of time [103].

\section{American Muslims Engaged in Culture Production}

In recent history, American Muslims have played an integral part in American sports, often as wildly popular professional athletes. ${ }^{7}$ They have engaged pop culture as musicians, actors, and TV personalities [104]. ${ }^{8}$ American Muslim comics are also gaining recognition and becoming household names. ${ }^{9}$ Only recently, however, have American Muslims begun making their stories known through the medium of film. Before 9/11, Muslims were regularly depicted as the stock "bad guys" in mainstream Hollywood movies. In a 2013 article by Philip Giraldi, "Why We Hate Them: Arabs in Western Eyes," Geraldi explains that in early films, "Arabs were increasingly depicted... as lawless savages who mindlessly opposed the advanced civilizations of Europe, not unlike the American Indians who had stood in the way of manifest destiny" [105]. In line with the "good Muslim, bad Muslim" effect discussed above, Geraldi argues that good Arabs conformed while "the bad Arabs were the 'disobedient' who sought to maintain their traditional ways of life." The exact terms of this dichotomy may have shifted with time, but many American Muslims continued to struggle with the "good Muslim, bad Muslim" paradox throughout the last decade. No longer complacently accepting a subaltern status, American Muslims have begun to enter the movie-making business and are intent on making a positive difference in the way Muslims are characterized.

Movies made by and about Muslims in the United States include the 2009 film, Amreeka, by Cherien Dabis and Nisreen Faour, or the 2007 short film, Arab in America by Nabil Abou-Harb, and the 2011 movie, Mooz-Lum, by Qasim Basir starring Danny Glover. However, aspiring American Muslim filmmakers are seeking innovative ways to fund their creative visions for original motion pictures like Adeela by Nicholas Paul Ybarra. Adeela is a movie in the making that is struggling to raise funds to move into the production phase. The movie seeks to tell the story of a Muslim girl raised in the United States who falls for a Jewish boy and experiences a "culture clash in America" [106]. It is taking time for American Muslims to make it in Hollywood but it is significant nonetheless that people like the creators of Adeela are not giving up.

In the meantime, filmmakers who are sympathetic to the plight of Muslims in America, like Evangelical Reverend Steven D. Martin of Tennessee, are using their resources to produce short documentaries such the 2012 film Islam in America: The Christian Truth [107]. The film features American Muslim leaders who are known for their positive messaging about American Muslim identity and Islam in America. Most prominently among them is Islamic Society of North America President Imam Mohamed Magid, and the first Muslim university chaplain in the United States,

\footnotetext{
E.g., Muhammad Ali, Kareem Abdul-Jabbar, Mike Tyson, Shaquille O’Neal, Hakeem Olajuwon, and Rasheed Wallace.

8 Famous American Muslim Musicians: Casey Kasem, Yusuf Islam, formerly Cat Stevens, Yusef Lateef, and famous rappers like Ice Cube, Lupe Fiasco, Mos Def, Snoop Dogg, Q-Tip, Immortal Technique, Busta Rhymes, T-Pain. Actors and TV personalities: Mehmet Oz, a.k.a. Dr. Oz, Iffran Khan, Shohreh Aghdashloo, Sayed Badreya, and Said Taghmaoui.

9 Comedians: Dave Chappelle, Aasif Mandvi, Dean Obeidullah, Azhar Usman, and Ahmed Ahmed.
} 
Imam Yahya Hendi. Islamic scholar John Esposito is also interviewed. These individuals helped portray the struggles of American Muslims in the face of rising Islamophobia after 9/11. Along these lines, the 2010 American Congregations report, A Decade of Change 2000-2010, documents efforts by various Christian denominations to reach out to members of other faiths, including Muslims [108].

As American Muslims moved toward greater engagement in local, state, and federal government after 9/11, they re-examined many of their previously held social conservative stances [109]. While a majority of Muslims voted Republican before 9/11 out of support for the domestic policies of the party that reflected "traditional values," the processes of integration post-9/11 served as an opportunity for American Muslims to re-evaluate their own positions on issues of national importance, such as religious freedom and, as we have seen, gay rights [110].

\section{American Muslims Engaging in New Ways}

American Muslims have responded to Islamophobia and shari'aphobia in variegated and creative ways [111]. They have assumed a redemptive posture in combatting misinformation about Islam and American Muslim identity while reclaiming each by supporting, participating in, and initiating community and civic engagement projects as well as contributing to U.S. politics, popular culture, and an ongoing national interfaith dialogue. American Muslims today emphasize what they see as shared American and Islamic values of honoring and celebrating difference. They also envision their efforts to integrate Islam into the tapestry of American society as a way of protecting themselves from the phobias that adversely affect and threaten their communities.

In 2006, the first Muslim congressman in the U.S., Keith Ellison of Minnesota, was sworn into office on a copy of Thomas Jefferson's Qur'an from 1734, after much consternation over whether or not an oath is valid on any scripture other than the Bible [112]. His experience paved the way in 2008 for Andre Carson, democrat from Indiana, the second Muslim elected to Congress whose campaign and election were much quieter and drew fewer questions about his religion [113].

American Muslims today understand newfound forms of cultural engagement and civic activism to be important avenues for securing the right of religious freedom in the name of the Constitution and the Bill of Rights for American Muslims. U.S.-based partnerships like the 501(c)(3) Clergy Beyond Borders (CBB), founded jointly by Muslim, Jewish, and Christian American clerics, further illustrate this larger trend among forward-looking Muslim Americans and their counterparts in other faiths to integrate Islam into America's cultural and religious fabric. The CBB website emphasizes the organization's vision that "all religions contain a message of commitment to improving the world" [114]. CBB advocates "mutual recognition among religious communities, seeking not to remove meaningful borders between them, but rather to build bridges of understanding and cooperation" [114]. Like American Muslim youth organizations, part of the goal of CBB is to educate non-Muslims and Muslims about the uniquely democratic, pluralistic, and modern nature of Islam, or at least American Islam [114,115]. Muslim American youth have set out to integrate Islam into the American popular conception of religious pluralism and diversity through the modern avenues of networking, blogging, events on college campuses, and conferences and seminars open to the public that cater to non-Muslims around the country [116]. 
Other Muslim-based organizations, including the United Muslims of America (UMA), the American Muslim Alliance (AMA), the Council on American Islamic Relations (CAIR), the Muslim Ummah of North America (MUNA), and the Muslim Public Affairs Council (MPAC), began increasingly to support interfaith engagement across the United States after 9/11 [117]. Appropriating "One God We Trust," UMA's website features a full section devoted to interfaith activism. The description of the section explains that UMA sees "America as one nation, endeavoring to create one family through interfaith understanding. We promote racial and religious harmony through religious institutions, projecting an image of America as a world leader who stands up for the human rights for all communities." Eboo Patel, well-known for his work in interfaith around the world, drew a lot of attention with the establishment of the Interfaith Youth Core that some people likened to a "Muslim Peace Corps" interfaith organization [117].

American Muslims have found a kind of special kinship with American Jews in working toward greater interfaith cooperation [118]. Not to be left in the dust of the rapid advancements in post-9/11 Muslim interfaith engagement, ISNA president Mohamed Magid and a delegation of imams from around the world, along with Congressman Keith Ellison, traveled with the U.S. State Department to the Wall of Death in Auschwitz, Germany to offer prayers where many thousands of Jewish prisoners were killed during the Nazi Holocaust [119].

Muslim-Christian alliances in the 12 years after 9/11 have also expanded widely and, along with improving Muslim-Jewish relations, may help to create a more accepting space for American Muslims in U.S. society in the long term [120]. American Muslim communities, particularly mosques, which may not be directly affiliated with interfaith organizations, have also opened their doors to Americans of other faiths to join in worship services as well as holiday celebrations. American Muslims have also led prayer services and vigils at times of national mourning in the last 12 years, whether or not the assailant was allegedly Muslim [121]. Ramadan, the holy Muslim month of fasting, provides an opportune venue for interfaith engagement at meals where Muslims are encouraged to break the day's fast with their neighbors [122].

An important feature of American Islam in the last 12 years has also been intra-faith dialogue and engagement - "intra-faith" in this case refers to work by American Muslims on improving Sunni-Shi'a relations. The website The American Muslim (TAM), run by Sheila Musaji, a leader in developing frameworks of understanding American Islam, quotes a 1959 fatwa, or religious treatise, by Shaikh Mahmood Shaltoot of Al-Azhar University: "Islam does not require a Muslim to follow a particular Madh'hab (school of thought). Rather, we say: every Muslim has the right to follow one of the schools of thought which has been correctly narrated and its verdicts have been compiled in its books" [123]. The excerpt goes on to specify that the Shi'ite school of thought is "religiously correct to follow in worship as are other Sunni schools of thought." Musaji's piece includes a nearly exhaustive list of articles and links to websites dedicated to Sunni-Shi'a, or "SuShi", reconciliation, mutual understanding, and intra-faith engagement [124]. This too marks a significant shift in American Muslim attitudes since 9/11. Whereas before 9/11, American Muslims either ignored Sunni-Shi'a issues or assumed sectarianism was not a problem in the United States, post-9/11, American Muslims are acknowledging that this is an important area with increasingly profound consequences for the world community of Muslims [125]. In fact, the sphere of 
Sunni-Shi'a intra-faith activism may be one field in which American Muslims are leading the way forward internationally.

Amid rising tensions between Sunni and Shi' a Muslims in Iraq, Pakistan, Lebanon, Syria and other countries where sectarian violence has spilled over into civil war and attempts at genocide, a group of American Muslim scholars and Imams were convened by ISNA in September 2013 to sign the "Washington Declaration Uniting Shi'ah and Sunni Scholars of North America" [126]. According to one of the signatories, "this declaration rejects all forms of sectarian violence between schools of thought within Islam... It calls for the respect of religious symbols of all sects of Islam... (and) for dialogue between the schools of thought and calls for imams to carry this message of mutual respect to their communities" [127]. ISNA president Mohamed Magid asserted that "ISNA is a platform for the unity of Muslims - whatever brings Muslim together strengthens all of them."

Among some of the most active groups of American Muslims in the pre- and post-9/11 efforts to integrate Islam into the mainstream of American psyches and culture have been activist youth programs [128]. The February 2010 Purple Hijab Day was promoted as an annual event where women don purple headscarves to end domestic violence "in our ummah," a reference to the Muslim community [129]. Green Muslims in the District, based in Washington D.C., have evolved from an online blog to a full website where events are coordinated, such as Zero Trash Parties and networking mixers for Muslim green activists to meet and pool efforts [130]. The nationwide Ramadan Fast-a-Thon has quickly developed a positive legacy on campuses across the country. Muslim Student Associations typically organize a day of fasting where non-Muslims are invited to join their Muslim classmates in abstaining from food and water from sunup to sundown and are then welcomed to partake in a special meal to break the fast (iftar) and accompanying prayers. They donate the funds they gather to a charity. Students spend the day in communication and many participants have explained that Fast-a-Thon helped them better relate to Muslims in America and at their universities. ${ }^{10}$ Other programs established by American Muslims are run by professionals but targeted toward American Muslim youth, such as IMAN's Takin' it to the Streets, Patel's above-mentioned Interfaith Youth Core (IFYC), and the Muslim Public Service Network (MPSN) [131].

More and more Muslim college students are finding creative ways to reach out to their local communities beyond their campuses as well. Georgetown University's Muslim Chaplaincy, one of only 13 such programs in the United States, offered a "Muslim Alternative Spring Break" for the first time in March 2012. After a competitive selection process, 12 Muslim undergraduate students led by their campus Imam traveled to Parkersburg, West Virginia to work with Habitat for Humanity building homes for a family in need. Students spent their entire Spring Break in service working side-by-side in the community. Parkersburg is a city with likely very little to no direct exposure to Islam or Muslims in the recent past. The Georgetown group attended church services in solidarity with the local community and baked cookies for the congregation after the service. The church community broke bread with the Muslim students before the week's end, and they are

10 There is no official website for Ramadan Fast-a-Thon at this time but Vanderbilt University's description is helpful. Available: < http://www.vanderbilt.edu/leadership/signature-events/ramadan-fast-a-thon-by-msa >. 
working to maintain strong ties and possibly return to Parkersburg the following year. Their service was noted by local newspapers and television news media who pointed out that these students willingly came to snowy Parkersburg rather than enjoy a more "traditional" Spring Break [132].

As American Muslims come to define Islam in America, they are also poised to contribute to Islamic scholarship and the training of Imams. In 2008, the Zaytuna Institute, founded in 1996 in Berkeley, California by Muslim "rock stars" Hamza Yusuf, Zaid Shakir, and Hatem Bezian, became Zaytuna College. The college follows an integrated curriculum of Islamic studies, Arabic language, and liberal arts including U.S. history and literature. Its motto is "Where America meets Islam," and its goal is to be accredited by the University of California system - it compares itself to private religiously-based universities founded by American Jews and Christians [133].

\section{Conclusions: Re-telling the Story of Islam in America}

The question of the future of Islam in America is tethered to our understanding of the history of Muslims in America before and after 9/11, as it always has been. However, in this study we have attempted to demonstrate the utter complexity and irreducible polyvocality of this large and diverse community of Americans. There are no easy answers as to whether Islamophobia will ever loosen its grasp on the psyches of millions of Americans who lived through 9/11 and witnessed 12 years of sporadic 'homegrown' attacks on American soil and cannot help but associate Islam and Muslims with terrorism and violence. However, there have been and continue to be transformations in Muslim identity in the United States and paradigm shifts in what Islam means in American contexts as well as what constitutes Islamic values and practices for American Muslims.

American Muslims are leaving behind the familiar grievance narratives about Islamophobia and instead are responding to fear, ignorance, hate, and even violence in creative, positive, and culturally substantive ways through art, media, film, writing, scholarship, partnerships, and institution-building. To be sure, the everyday lives of Muslims in America who struggle to reconcile their identities require further analysis. This whirlwind glance at the status of Muslims and Islam in the U.S. in the last 12 years has revealed some of the polygonal and quixotic ways individuals and communities are re-negotiating their identities in relation to their changing interpretations of and attitudes about Islam and religiosity. While this article extrapolates upon several types of trends in American Islam, no one major trend per se has arisen that can capture the multifaceted nature of "an American Muslim community." Instead, we are left with a greater appreciation of liberal- and less- or even anti-liberal leanings and trends in a vast plurality of American Muslim communities. These individuals and collectivities are not shaped by $9 / 11$ or Islamophobia, nor do they occupy a penumbral space in the shadow of the specter of terrorism. American Muslim identities and emergent forms of American Islam were never circumscribed by terrorism narratives and today they continue to defy and subvert assumptions about Islam and Muslim identity.

American Muslim communities, and individuals, make decisions on a regular basis that challenge prototypical idealizations and stereotypes of Islam - they choose to reform, or not, and American Muslims perceived as "conservative" or "traditional" are increasingly engaged in American society and aware of their decisions. They operate on informed rationalities, as do their counterparts who have chosen different paths of practice, spirituality, and epistemology. What 
these tides in American Islam share is a common hope and struggle for acceptance and integration into the broader American tapestry of culture, religion, politics, and sociality. In many senses, the proverbial ball is now in the court of non-Muslim Americans who must decide how they will choose to perceive, categorize, interact with, interpret, and respond to American Muslims and American Islam as well as Muslims and Islam in America - the two are not always the same, particularly among communities of Muslims who may be more recent immigrants to the United States. In its relatively short history, the United States has already undergone major societal transformations to accommodate groups of people who were previously marginalized, demonized, or otherwise subjugated and discriminated against. Will the next sea change in American society be to end the "othering" of Islam and Muslims? Will the nearly 50\% of Americans who believe Muslims pose a threat to national security re-examine their assumptions about nationalism, patriotism, American exceptionalism, and of course Islam or 'Islamism' to create a safe space for American Muslims? [19,134].

Not long ago, Muslims in the United States prided themselves on their Islamic exceptionalism and isolated themselves from American society. In 2007, 47\% of American Muslims surveyed identified Islam as their primary allegiance above that of nation and citizenship [135]. Islam maintained a special dispensation and was a source of security that allowed America's Muslims to stand outside while simultaneously living within American society. Muslims in America seemed content to live on the edges of the mainstream until 9/11. Ten years later, America's Muslims are engaged and struggling to enter the mainstream of American society.

In the months and years after 9/11 under the Bush and Obama administrations, both American Muslims and the U.S. government have worked toward integrating American Muslims into American society [136]. However, persistent fear, widespread prior misconceptions, and an ongoing lack of cultural literacy about Islam and Muslims after 9/11 resulted in the rise of anti-Muslim, or Islamophobic, sentiment among many conservatives and, undoubtedly, opportunists in the United States. Today, American Muslims have a long way to go to secure either a safe or at least a less-contested space in American society. Yet, through their continued and ever-more diverse efforts, the prospect of Islam becoming widely accepted as an American religion is becoming increasingly real.

There are encouraging signs of a more defined and recognizable narrative of Islam as part of the family of American religions. Keeping with the tradition of annual White House Ramadan dinners started by his predecessor, George W. Bush, Barack Obama attended the 2011 Ramadan breaking fast dinner at the White House. In his speech to the audience, Obama stated, "Islam has always been part of America," and "America and Islam are not exclusive and need not be in competition. Instead, they overlap, and share common principles of justice and progress, tolerance and the dignity of all human beings" [137]. This type of acknowledgement coming from the President may help to advance the efforts of American Muslims working to gain broad, cultural acceptance of Islam as an American religion, but, for many of the individuals involved in Islamic literacy work, speeches are not sufficient on their own.

Our research has found that there has been a notable shift from a Muslim identity politics based on disassociating from American identity, or 'American exceptionalism' and its cultural trappings, to a stance of integration and cultural assimilation. That is not to say that Muslims have abandoned 
their customs to conform to an Anglo-American imaginary, but that many American Muslims have redoubled efforts to retell the story of Islam in America-sometimes claiming origins that date back to the 12th century [138]. American Muslims in the last 12 years have also sought to substantiate their claims about a copacetic identity that is both American and Muslim by writing about Islam as an authentically American religion; indeed, since 9/11 there has been a plethora of publications both online and in print dedicated to the notion that Islam is an American religion and that Muslims are every bit as American as their Jewish and Christian counterparts [8]. These works are another piece of the intricate tapestry of projects and movements American Muslims have initiated since $9 / 11$.

Combined, these undertakings illustrate a certain set of social shifts taking place in American Muslim communities and intellectual circles. These changes reflect the evolving realities of a more deeply rooted immigrant population as well as the complex and lasting impact of 9/11 on America's most diverse and vulnerable religious community as it struggles to gain acceptance into mainstream American society through the practice of different but integrated forms of American Islam [139].

\section{Author Contributions}

Yvonne Haddad and Nazir Harb co-authored the article based on research made possible by funding support from the Dean of the School of Foreign Service at Georgetown University.

\section{Conflicts of Interest}

The authors declare no conflict of interest.

\section{References and Notes}

1. Joseph Margulies. What Changes When Everything Changed: $9 / 11$ and the Making of National Identity. New Haven: Yale University Press, 2013.

2. Leonard Picker. "9/11 Changed Everything." Publishers Weekly 252 (2005): 180.

3. John N. Duvall, and Robert P. Marzec. "Narrating 9/11." MFS Modern Fiction Studies 57 (2011): 381-400.

4. Anny Bakalian, and Bozorgmehr Mehdi. Backlash 9/11: Middle Eastern and Muslim Americans Respond. Berkeley: University of California Press, 2009.

5. Nathan Lane. "Since 9/11, U.S. policy Enforced Islamophobia." CNN, 11 September 2013. http://religion.blogs.cnn.com/2013/09/11/since-911-islamophobia-legislated-and-enforced.

6. Yvonne Yazbeck Haddad. Muslims in the West: From Sojourners to Citizens. Oxford: Oxford University Press, 2002.

7. Hilal Elver. "Racializing Islam Before and After 9/11: From Melting Pot to Islamophobia." Transnational Law \& Contemporary Problems 21 (2012). Available online: http://www.uiowa.edu/ tlcp/TLCP\%20Articles/21-1/elver_final.pdf (accessed on 28 October 2013).

8. Yuting Wang. Between Islam and the American Dream: An Immigrant Muslim Community in Post-9/11 America. New York: Routledge, 2013. 
9. Edward W. Said. Orientalism. New York: Vintage Books, 1979.

10. Taylor Hom. “Anatomy of Islamophobia.” World Policy Journal 28 (2011): 14-15.

11. Salman Sayyid, and AbdoolKarim Vakil. Thinking through Islamophobia: Global Perspectives. New York: Columbia University Press, 2010.

12. Turan Kayaoglu. “Three Takes on Islamophobia.” International Sociology 27 (2012): 609-15.

13. Gema Martín-Muñoz. "Unconscious Islamophobia.” Human Architecture 8 (2010): 21-28.

14. Stephen Sheehi. Islamophobia: The Ideological Campaign against Muslims. Atlanta, GA: Clarity Press, 2011.

15. David E. Sanger. "Islamophobia." The New York Times, 10 May 2009, A 23.

16. Carl Coon. "Islamophobia." The Humanist 66 (2006): 4-5.

17. Christopher Allen. Islamophobia. Farnham, Surrey: Ashgate, 2010.

18. Stephen Schwartz. "Islamophobia: America's New Fear Industry." Phi Kappa Phi Forum 90, no. 3 (2010): 19.

19. John. L. Esposito, and I. Kalın. Islamophobia: The Challenge of Pluralism in the 21st Century. Oxford: Oxford University Press, 2011.

20. Peter Gottschalk, and Gabriel Greenberg. Islamophobia: Making Muslims the Enemy. Lanham: Rowman \& Littlefield Publishers, 2008.

21. J. Mark Halstead. "Islamophobia." In Encyclopedia of Race, Ethnicity, and Society. Edited by Richard T. Schaefer. New York: Sage Publications, 2008, pp. 763-65.

22. Sid Roth. (Guest: Erick Stakelbeck, 6 September 2013), Sidroth.org. Available online: http://sidroth.org/television/this-weeks-episode (accessed 18 September 2013).

23. Abraham Nabeel, Sally Howell, and Andrew Shryock, eds. Arab Detroit 9/11: Life in the Terror Decade. Detroit: Wayne State University Press, 2011.

24. Matthew Harwood. "FBI Discriminates Against American Muslims \& Lets White Terrorists Off the Hook." Informed Comment: Thoughts on the Middle East, History and Religion, 10 July 2013. http://www.juancole.com/2013/07/discriminates-american-terrorists.html (accessed on 13 September 2013).

25. Pamela Geller. "Robert Spencer Toronto Talk Flagged by Canadian Muslim Leaders." The Huffington Post, 13 September 2013. http://www.huffingtonpost.ca/2013/09/13/pamelageller-robert-spencer-toronto-islam_n_3921013.html.

26. Michelle Malkin. "Muslim Enemies Lurk Within.” Human Events 57 (2001): 16.

27. "Muslim Extremism in Europe: The Enemy Within." The Economist 376 (2005): 24. http://www.economist.com/node/4174260 (accessed on 27 November 2013).

28. Haroon Siddiqui. Being Muslim. Toronto: Groundwood Books, 2006.

29. Jasmin Zine, ed. Islam in the Hinterlands: Muslim Cultural Politics in Canada. Vancouver: UBC Press, 2012.

30. Arshad Alam. "The Enemy Within: Madrasa and Muslim Identity in North India." Modern Asian Studies 42 (2008): 605-27.

31. Mapping Muslims: NYPD Spying and its Impact on American Muslims (2013). The Muslim American Civil Liberties Coalition, CUNY's Creating Law Enforcement Accountability \& Responsibility Project, and the Asian American Legal Defense and Education Fund. New 
York: CLEAR Project, AALDEF, MACLC. Available online: http://www.law.cuny.edu/ academics/clinics/immigration/clear/Mapping-Muslims.pdf (accessed on 11 September 2013).

32. Eileen Sullivan. "Obama Administration Helps Pay For NYPD Muslim Surveillance." Pittsburgh Post-Gazette, 28 February 2012. http://www.post-gazette.com/nation/2012/02/ 28/Obama-administration-helps-pay-for-NYPD-Muslim-surveillance/stories/201202280426.

33. Mohamed Nimer. "American Muslims and the Obama Administration." Emirates Center for Strategic Studies and Research (Abu Dhabi). Emirates Lecture Series 82 (2010): 1-35, 37-43.

34. Courtney C. Radsch. "U.S. Muslims Seek Jobs with Obama Administration." Al Arabiya News, 30 March 2009. http://www.alarabiya.net/articles/2009/03/30/69589.html.

35. Glenn Greenwald. "Obama Moves to Make the War on Terror Permanent." The Guardian, 24 October 2012. http://www.theguardian.com/commentisfree/2012/oct/24/obama-terrorism-kill-list.

36. Geraldine Coughlan. "Theo van Gogh: Controversial Film-maker." The Independent, 4 November 2004. http://www.independent.co.uk/news/obituaries/theo-van-gogh-6158646.html.

37. Peter Overby, and Will Evans. "Some Answers on Clarion, and Still Some Questions." NPR, 7 October 2008. http://www.npr.org/blogs/secretmoney/2008/10/clarion_answers_some_ questions.html.

38. "Lecture of the Holy Father - Faith, Reason and the University Memories and Reflections." Libreria Editrice Vaticana, 12 September 2006. Quoted in "Muslim Reaction to Pope." BBC News, 15 September 2006. Retrieved 13 August 2007. http://news.bbc.co.uk/2/hi/europe/ 5348436.stm (accessed on 13 August 2007).

39. Benjamin Harvey. "Pope's Remarks Agitate Muslim world." The Orlando Sentinel, 16 September 2006, A.1.

40. Israel/Gaza: Operation 'Cast Lead': 22 Days of Death and Destruction. London: Amnesty International Publications, 2009. Available online: http:/www.amnesty.org/en/library/asset/ MDE15/015/2009/en/8f299083-9a74-4853-860f-0563725e633a/mde150152009en.pdf (accessed on 23 July 2013).

41. Jonathan Rosenblum. "Think Again: Purim in Contemporary Guise." Jerusalem Post, 1 March 2012. http://brandeiscenter.com/index.php?/news/news_full/think_again_purim_in_ contemporary_guise.

42. "Gaffney on Fox: Obama Trend in 'Arab Spring' is To Support Enemies of Freedom." YouTube, 1 November 2011. Posted by Securefreedom. Available online: http://www.youtube.com/watch?v=I0q6y1ZffuM (accessed on 13 August 2013).

43. Paul Cruickshank, Tim Lister, Nick Robertson, and Fran Townsend. "Sources: 3 Al Qaeda Operatives Took Part in Benghazi Attack." CNN, 4 May 2013. http://www.cnn.com/2013/05/02/world/africa/us-libya-benghazi-suspects/.

44. Victoria Kim. "Some Question Jailing of Film's Creator; Free Speech Advocates Worry 'Innocence of Muslims,' Not Alleged Probation Violations, Prompted Detention." The Los Angeles Times, 3 October 2012, A.1.

45. Sarah Chayes. "Does 'Innocence of Muslims' Meet The Free-Speech Test?” The Los Angeles Times, 18 September 2012. http://articles.latimes.com/2012/sep/18/opinion/la-oe-chayesinnocence-of-muslims-first-amendment-20120918. 
46. Michael S. Schmidt. "Libyan Militia Leader Charged in Fatal 2012 Benghazi Attack." The Virginian-Pilot, 7 August 2013. http://www.highbeam.com/doc/1G1-339060970.html.

47. Jerome Socolovsky. Anti-Islam film Linked to 'Islamophobic Industry'. The New Turkey, 17 September 2012. http://www.thenewturkey.org/anti-islam-film-linked-to-islamophobicindustry/new-region/128.

48. Omar Sacirbey. "Poll: Anti-Muslim Sentiment Grew After Bin Laden Death." The Christian Century Online, 21 July 2011. http://www.christiancentury.org/article/2011-07/poll-antimuslim-sentiment-grew-after-bin-laden-death.

49. Stephen E. Atkins. The 9/11 Encyclopedia. Santa Barbara, CA: ABC-CLIO, 2011.

50. Wajahat Ali, Eli Clifton, Matthew Duss, Lee Fang, Scott Keyes, and Faiz Shakir, "Fear, Inc.: The Roots of the Islamophobia Network in America." Center for American Progress, 26 August 2011. http://www.americanprogress.org/issues/religion/report/2011/08/26/10165/fear-inc/.

51. CAIR annual Islamophobia reports and briefs: http://www.cair.com/islamophobia/ islamophobia-reports-other-documents.html (accessed on 31 December 2013).

52. Nathan Lean. The Islamophobia Industry: How the Right Manufactures Fear of Muslims. London: Pluto Books, 2012.

53. “CAIR Welcomes Voters' Rejection of Islamophobic Candidates." $P R \quad$ Newswire, 7 November 2012. http://search.proquest.com/docview/1140264855?accountid=11091.

54. Roger Scruton. "The Islamification of Our Law: Liberal Absolutism Threatens Our Ancient Liberties." The Spectator 291 (2003): 26-33.

55. Paul A. Marshall. Radical Islam's Rules: The Worldwide Spread of Extreme Shari'a Law. Lanham, MD: Rowman \& Littlefield Publishers, 2005.

56. Ayaan Hirsi Ali. "Shari'a in Swat: A Dangerous Surrender to Islamists." New Perspectives Quarterly 26 (2009): 22-24.

57. Jim Lobe. "Neocons Seek Islamic 'Reformation." antiwar.com, 8 April 2004. http://www.antiwar.com/lobe/?articleid=2273.

58. M. A. Muqtedar Khan. Debating Moderate Islam: The Geopolitics of Islam and the West. Salt Lake City: University of Utah Press, 2007.

59. "Racist Group Linked to PBS 'Moderate Muslims' Documentary." PR Newswire, 28 June 2007. http://www.prnewswire.com/news-releases/racist-group-linked-to-pbs-moderatemuslims-documentary-58544352.html.

60. “Obama Made Right Call on Mosque." Chicago Defender, 25 August 2010. http://www.highbeam.com/doc/1P3-2132223891.html.

61. Laura Leslie. "Sharia Law Ban Headed to McCroy." WRAL.com, 34 July 2013. http:/www.wral.com/sharia-law-ban-headed-to-mccrory/12700764/.

62. Nathan Lean. "Since 9/11, U.S. Policy Enforces Islamophobia”. CNN Belief Blog, 11 September 2013. Available online: http://religion.blogs.cnn.com/2013/09/11/since-911islamophobia-legislated-and-enforced/ (accessed on 11 September 2013).

63. Bradford J. Kelley. "Bad Moon Rising: The Sharia Law Bans." Louisiana Law Review 73 (2013): 601-31. http://digitalcommons.law.lsu.edu/lalrev/vol73/iss2/9.

64. Mahmood Mamdani. Good Muslim, Bad Muslim: America, the Cold War, and the Roots of Terror. New York: Pantheon Books, 2004. 
65. Tariq Ramadan. “Good Muslim, Bad Muslim.” New Statesman 139 (2010): 22-25.

66. Sanya Osha. "Book Review: Good Muslim, Bad Muslim." Journal of Asian and African Studies 40 (2005): 483-85.

67. "The Chicago Council on Global Affairs, Task Force on Religion and the Making of U.S. Foreign Policy." Engaging Religious Communities Abroad: A New Imperative for U.S. Foreign Policy, 2010. Available online: http://www.thechicagocouncil.org/ UserFiles/File/Task\%20Force\%20Reports/2010\%20Religion\%20Task\%20Force_Full\%20Re port.pdf (accessed on 5 September 2013).

68. Saba Mahmood. "Secularism, Hermeneutics, and Empire: The Politics of Islamic Reformation." Public Culture: Bulletin of the Project for Transnational Cultural Studies 18 (2006): 323-47.

69. Yvonne Y. Haddad. "Muslims and American Religious Pluralism." In Gods in America: Religious Pluralism in the United States. Edited by Charles L. Cohen and Ronald L. Numbers. New York: Oxford University Press, 2013.

70. Daniel Pipes. "The Danger Within: Militant Islam in America." Commentary 112 (2001), 19-24.

71. “CAIR Asks Alaska Lawmaker To Drop Hate Group Leader As Witness.” PR Newswire, 29 March 2011. http://www.prnewswire.com/news-releases/cair-asks-alaska-lawmaker-to-drophate-group-leader-as-witness-118851719.html.

72. "Society of Americans for National Existence (SANE) Announces Mapping Shari'a in America Project." PR Newswire, 13 June 2007. http://www.prnewswire.com/newsreleases/society-of-americans-for-national-existence-sane-announces-mapping-sharia-inamerica-project-59323187.html.

73. "CAIR: Washington Times Promotes Hate Group That Would Outlaw Islam; 'Adherence to Islam' Would Be Punishable by 20 Years in Prison.” PR Newswire, 14 June 2007. http://www.prnewswire.com/news-releases/cair-washington-times-promotes-hate-group-thatwould-outlaw-islam-58111582.html.

74. Sheila Musaji. “A Who's Who of the Anti-Muslim/Anti-Arab/Islamophobia Industry.” The American Muslim, 15 October 2012. http://theamericanmuslim.org/tam.php/features/articles/ a_whos_who_of_the_anti-muslimanti-arabislamophobia_industry.

75. Quoted in David Mizner. "The Orthodox Jewish White Supremacist Behind the Anti-Sharia Movement." Daily Kos, 2 March 2011. http:/www.dailykos.com/story/2011/03/02/951540/The-Orthodox-Jewish-White-Supremacist-Behind-the-Anti-Sharia-Movement\#.

76. Yvonne Y. Haddad, and Nazir Harb. "The New American Identity: Defining American Islam over a Decade of Transformation." In Beyond 9/11: Transdisciplinary Perspectives on Twenty-first Century U.S. American Culture. Edited by Christian Kloeckner, Simone Knewitz and Sabine Sielke. Frankfurt: Peter Lang GmbH, 2013.

77. Clarence Page. "Obama Claims License to Kill by Drone." Philadelphia Tribune, 10 February 2013.

78. Yasmin Alibhai Brown. "Behind the Use of Drones is a Complacent Belief That Murdering Muslims is Always Justifiable." The Independent, 28 April 2013. http://www.independent.co.uk/voices/comment/behind-the-use-of-drones-is-a-complacentbelief-that-murdering-muslims-is-always-justifiable-8591521.html. 
79. Stephen Walt. "The Myth of American Exceptionalism." Foreign Policy 189 (2011). http://www.foreignpolicy.com/articles/2011/10/11/the_myth_of_american_exceptionalism?p age $=0,0$.

80. Tariq Modood. Multicultural Politics: Racism, Ethnicity, and Muslims in Britain. Minneapolis: University of Minnesota Press, 2005.

81. Qasim Rashid. "Muslim American Loyalty-1 Year after Fort Hood." The Huffington Post, 5 November 2010. http://www.huffingtonpost.com/qasim-rashid/post_1201_b_778968.html.

82. Yvonne Y. Haddad. Becoming American? The Forging of Arab and Muslim Identity in Pluralist America. Waco, TX: Baylor University Press, 2011.

83. Umar Faruq Abd-Allah, 2009. "Islam and the Cultural Imperative." CrossCurrents 56 (2006): 357.

84. Omid Safi, ed. Progressive Muslims on Justice, Gender, and Pluralism. London: Oneworld Publications, 2003.

85. "First American Muslim Charities Accredited through Groundbreaking National Program." Muslim Advocates, 25 August 2009. http://www.muslimadvocates.org/ first_american_muslim_charities_accredited_through_groundbreaking_national_program.

86. Abdulkader H. Sinno. Muslims in Western Politics. Bloomington: Indiana University Press, 2009.

87. ISNA official flyer for 2013 Annual Conference. Available online: http://www.isna.net/ uploads/1/5/7/4/15744382/program_web.pdf (accessed on 9 September 2013).

88. Yasmin Mogahed. Reclaim Your Heart: Personal Insights on Breaking Free from Life's Shackles. San Clemente, CA: FB Publishing, 2012.

89. Yasmin Mogahed. "Yasmin Mogahed." The Huffington Post. Available online: http://www.huffingtonpost.com/yasmin-mogahed/ (accessed on 7 September 2013).

90. "Yasir Qadhi." Al-Maghrib Institute. Available online: http://almaghrib.org/instructors/yasirqadhi\#profile (accessed on 29 November 2013).

91. "Tennessee Imam: Jews and Christians Filthy." The Western Center for Journalism, 1 July 2013. http://www.westernjournalism.com/tennessee-imam-jews-and-christians-filthy-theirlives-and-property-hold-no-value/.

92. “Al-Maghrib Institute 2006 ISNA Convention Lineup." Available online: http://forums.almaghrib.org/showthread.php?t=16628 (accessed on 30 November 2013).

93. "Farhat Hashmi Operating in Canada." Daily Times (Washington), 6 May 2005. http://www.dailytimes.com.pk/default.asp?page=story_6-5-2005_pg7_49.

94. Faiza Mushtaq. "A Controversial Role Model for Pakistani Women." South Asian Multidisciplinary Academic Journal 4, 08 December 2010. http://samaj.revues.org/3030.

95. "Rights Groups File Lawsuit Challenging NYPD's Muslim Sureveillance Program." ACLU, 18 June 2013. https://www.aclu.org/national-security/rights-groups-file-lawsuit-challengingnypds-muslim-surveillance-program.

96. "Islamic Chaplaincy Program." Hartford Seminary. Available online: http://www.hartsem.edu/islamic-chaplaincy/faq (accessed on 25 November 2013).

97. Bernard Haykel. Revival and Reform in Islam: The Legacy of Muhammad al-Shawkañi . Cambridge, UK: Cambridge University Press, 2003. 
98. "Muslims for Progressive Values." Daayiee's Place of Inner Peace. Available online: http://daayieesplaceofinnerpeace.com/MPV-WASHINGTON_DC_2.html (accessed on 20 September 2013).

99. "Vision and Mission." Daayiee's Place of Inner Peace. Available online: http://daayieesplaceofinnerpeace.com/MISSION_VISION_C58I.html (accessed on 20 September 2013).

100. Neil Macfarquhar. "Gay Muslims Find Freedom, of a Sort, in the U.S." The New York Times, 7 November 2007. http://www.nytimes.com/2007/11/07/us/07gaymuslim.html?_r=2\&.

101. Jaweed Kaleem. "Progressive Muslims Launch Gay-Friendly, Women-Led Mosques in Attempt to Reform American Islam." The Huffington Post, 28 March 2012. http://www.huffingtonpost.com/2012/03/29/progressive-muslims-launch-gay-friendly-womenled-mosques_n_1368460.html.

102. "Can Islam Reform from within?" American Thinker, 30 October 2009. http://www.americanthinker.com/2009/10/can_islam_reform_from_within.html.

103. Homepage of Al-Fatiha Foundation. Available online: al-fatiha.org (accessed on 22 September 2013).

104. Mariem Qamruzzaman. "Muslim Motown”. Islamic Horizons 38 (2009): 32-41.

105. Philip Giraldi. "Why We Hate Them: Arabs in Western Eyes," The American Conservative, 2 January 2013. http://www.theamericanconservative.com/articles/why-we-hate-them-arabs-inwestern-eyes/.

106. For the Kickstarter campaign see http://www.kickstarter.com/projects/adeelathemovie/adeela (accessed on 20 July 2013). For the official "Adeela" website, see: http://adeelathemovie.com/Adeela_The_Movie/Home.html (accessed on 20 July 2013).

107. Steve Martin. "Islam in America: The Christian Truth." YouTube, 14 September 2012. Available online: http://www.youtube.com/watch?v=9-50TZf10do\&desktop_uri=\% 2Fwatch\%3Fv\%3D9-50TZf10do\&nomobile=1 (accessed on 14 August 2013).

108. David A Roozen. "American Congregations Reach Out to Other Faith Traditions: A Decade of Change 2000-2010." Faith Communities Today. Hartford: Hartford Institute for Religion Research, 2010. http://faithcommunitiestoday.org/sites/faithcommunitiestoday.org/files/ American_Congregations_Reach_Out.pdf.

109. Zeyno Baran. The Other Muslims: Moderate and Secular. New York: Palgrave Macmillan, 2010.

110. Yvonne Y. Haddad, Farid Senzai, and Jane Smith. Educating the Muslims of America. Oxford: Oxford University Press, 2009.

111. Sheila Musaji. "Muslim Voices against Extremism and Terrorism." The American Muslim. Available online: http://theamericanmuslim.org/tam.php/features/articles/muslim_voices_ against_extremism_and_terrorism_2/(accessed on 10 September 2013).

112. Frederic J. Frommer. "Congressman to Be Sworn in Using Quran." The Washington Post, 3 January 2007. http://www.washingtonpost.com/wpdyn/content/article/2007/01/03/AR2007010301179.html.

113. “Andrew Carson Becomes Second Muslim in Congress.” Trans World News, 12 March 2008. http://www.freerepublic.com/focus/f-news/1984464/posts. 
114. Clergy Beyond Borders. Available online: http://www.clergybeyondborders.org/ (accessed on 15 August 2013).

115. See UMA website. Available online: http://www.umanet.org/en/about_us/ (accessed on 1 August 2013).

116. Robert Wuthnow. America and the Challenges of Religious Diversity. Princeton: Princeton University Press, 2007.

117. "Voa News: American Muslim Models Interfaith Group On Peace Corps." US Fed News Service, Including US State News, 15 January 2007. Available online: http://search.proquest.com/ docview/472399705? accountid=11091 (accessed on 22 November 2013).

118. Nathan Guttman. "American Jews and Muslims Work Together: Concrete Projects Help Overcome Differences on Israel.” Forward, 26 September 2011. http://forward.com/articles/ 143338/american-jews-and-muslims-work-together/.

119. Elad Benari. "Muslim Imams Pray for Holocaust Victims at Auschwitz." Arutz Sheva, 23 May 2013. http://www.israelnationalnews.com/News/News.aspx/168243\#.UsNVvWRDuCA.

120. Mucahit Bilici. Finding Mecca in America: How Islam is Becoming an American Religion. Chicago: University of Chicago Press, 2012.

121. Abdur-Rahman Ubaid. "Muslims Lead Interfaith Prayers for Arizona Victims." The Washington Report on Middle East Affairs 30 (2011): 53.

122. Delinda C. Hanley. "Maryland Mosque Holds Interfaith Ramadan Iftar." The Washington Report on Middle East Affairs 32 (2013): 54-55.

123. Sheila Musaji. "Sunni \& Shiah Unity Resources." The American Muslim, originally published 23 January 2003, updated 10 December 2012. Available online: http://theamericanmuslim.org/ tam.php/features/articles/shia_sunni (accessed on 21 September 2013).

124. Hesham Hassaballa. "Shiite, Sunni and 'Sushi' Muslims". Islamic City, 25 March 2011. http://www.islamicity.com/articles/Articles.asp?ref=AC1103-4579.

125. Cathy Lynn Grossman. "Tension between Sunnis, Shiites Emerging in USA.” USA Today, 24 September 2007. http://usatoday30.usatoday.com/printedition/news/20070925/ 1a_cover25.art.htm.

126. "North American Sunni and Shi'a Muslims Sign Declaration." Iqra, 14 September 2013. http://iqra.ca/2013/north-american-sunni-and-shia-muslims-sign-declaration/.

127. Informal interview with Imam Yahya Hendi, 3 September 2013.

128. R. Bieringer, and D.J. Bolton. Reconciliation in Interfaith Perspective: Jewish, Christian and Muslim Voices. Leuven: Peeters Publishers, 2011.

129. "Purple Hijab Day.” Muslimas' Oasis, 8 January 2010. http://www.muslimasoasis.com/ 2010/01/purple-hijab-day/.

130. "Muslim Green Activists." Green Muslims. Available online: www.greenmuslims.org (accessed on 20 November 2013).

131. "Takin' it to the Streets." IMAN Central. Available online: http://www.imancentral.org/artsculture/takin-it-to-streets/ (accessed on 20 November 2013).

132. Shannon Houser. "College Students Spend Spring Break Building Homes." WTAP News, 5 March 2012. http://www.wtap.com/home/headlines/141499153.html. 
133. Zaytuna College homepage. Available online: http://www.ZaytunaCollege.org (accessed on 23 November 2013).

134. Gallup World. "Islamophobia: Understanding Anti-Muslim Sentiment in the West." Available online: http://www.gallup.com/poll/157082/islamophobia-understanding-antimuslim-sentiment-west.aspx (accessed on 21 September 2013).

135. Pew Research Center. "Muslim Americans.” Available online: http:/www.pewresearch.org/ topics/muslim-americans/ (accessed on 2 November 2013).

136. "Obama's Muslim Outreach Fiasco." The Washington Times, 18 June 2010. http://www.washingtontimes.com/news/2010/jun/18/obamas-muslim-outreach-fiasco/.

137. Christina Wilkie. "Obama's Ramadan Dinner Speech Pays Tribute to Muslim Americans." The Huffington Post, 10 August 2011. http:/www.huffingtonpost.com/2011/08/10/obamapays-tribute-to-mus_n_924011.html.

138. Abdus Sattar Ghazali. Chronology of Islam in America: 1178-2010. American Muslim Perspective. 1 January 2011. Available online: http://www.ghazali.net/thelight/ Chronology_of_Islam_in_America-F2.pdf(accessed on 1 September 2013).

139. “American Muslims Stand Out as a Multicultural Market with Significant Opportunities." PRWeb, 3 August 2011. Available online: http://news.yahoo.com/american-muslims-standmulticultural-market-significant-opportunities-110253473.html (accessed on 28 August 2013). 


\title{
Pervasive Anxiety about Islam: A Critical Reading of Contemporary 'Clash' Literature
}

\author{
Meena Sharify-Funk
}

\begin{abstract}
This article analyzes and critiques North American and European "clash literature"-a genre of post-9/11 writings that popularize elements of Samuel Huntington's "clash of civilizations" thesis, with particular reference to putative threats posed to Western civilization by Islam and Muslims. Attention is given to a series of salient themes used by multiple texts and authors, in a manner that creates an overarching narrative of Western moral superiority vis-à-vis a monolithic, authoritarian, and misogynistic Islamic culture; betrayal of Western culture by "politically correct" intellectual elites wedded to ideas of multicultural accommodation; and a cascading threat posed by the rapid influx of unassimilable Muslim immigrants who are poised to mount a demographic takeover of Europe and possibly America as well. The content of clash texts is then analyzed and evaluated in light of its detachment from relevant scholarship, its reliance on highly essentialized identity constructs, its use of demographic extrapolations and alarming anecdotes, and its stark rejection of contemporary pluralism. The article concludes with reflections on how scholars might respond to the identity insecurities revealed by clash literature as they seek to advance alternative narratives based on values of dialogue and coexistence.
\end{abstract}

Reprinted from Religions. Cite as: Sharify-Funk, M. "Pervasive Anxiety about Islam: A Critical Reading of Contemporary 'Clash' Literature.” Religions 4 (2013): 443-468.

\section{Introduction}

Since Samuel Huntington posited the now infamous "Clash of Civilizations" theory in a 1993 essay published in the journal Foreign Affairs, much academic controversy has flared around his assertion that cultural and religious differences will become the main source of international conflict in the post-Cold War era. Although Huntington's thesis has been frequently criticized by a broad spectrum of academics for its extremely broad-brush approach to conflict analysis and its vulnerability to manipulation as a conflict-intensifying cliché, the events of September 11, 2001 catapulted his ideas beyond the academy and into the heart of contemporary discourse. His predictions that civilizational conflicts would be especially prevalent between Muslims and non-Muslims received particular attention, as did his effort to shift discussion of international affairs from the ideological geopolitics of the Cold War to resurgent religio-cultural identities rooted deep in history. With statements on political geography such as, "Europe ends where 
Western Christianity ends and Islam and Orthodoxy begin," Huntington proposed that religiously based civilizations constitute the largest meaningful framework for human loyalty, and emphasized the frailty of political projects with broader scope and ambition, from the European Union to the United Nations. Huntington also arguably contributed to an intellectual atmosphere within which many less disciplined writers felt greater freedom to write their own manifestos linking contemporary concerns about terrorism to a primordial struggle between "Islam and the West".

While most academics ignore writings that might be construed as combative popularizations of Huntington's clash theory, the proliferation of exactly this variety of clash literature since September 11, 2001 constitutes a phenomenon worthy of investigation and analysis. This broader clash literature, which proclaims an intent to break the shackles of "political correctness" and tell the truth about Islam and the West, contains many volumes which have risen to best-seller heights and is deservedly controversial. In content as well as tone it is decidedly alarmist and insistently polarizing. Leaving behind the subtler forms of orientalist derogation critiqued by Edward Said in his influential thesis on the subject [1], the new clash literature represents Islam and the West ${ }^{11}$ as irreconcilable entities locked into ideological and sometimes actual warfare for decades if not centuries. Dismissing dialogue and relying on strident "us vs. them" rhetoric, the literature actively seeks to interfere with the development of relations between Muslims and non-Muslims. Though produced by authors of varied backgrounds, the written products display striking consistencies in core premises and ultimate conclusions, as "ex-Muslims" who generalize from negative personal experiences find common cause with atheists warning against religious resurgence as well as with theologians who worry that apocalyptic demographics will displace their religious heritage once and for all.

Given the astronomically higher sales of such books (e.g., Infidel and Surrender and America Alone) when compared to writings espousing dialogue and coexistence, themes from the clash literature have undeniably infiltrated the public imagination in Europe and North America, amplifying negative perceptions of Islam and Muslims and reinforcing popular anxieties. Though emphasis varies somewhat across texts and authors, books from the clash literature consistently encourage a culture of suspicion within which Islam and Muslims constitute a threat to Western societies. Islam is portrayed as the religious heritage of a dysfunctional and misogynist "tribal" society that prevents Muslims from adapting to modern settings and leaves all Muslims vulnerable to indoctrination with radical ideology. Because Islam is incompatible with cultural and political liberalism, Muslim immigrants cannot be integrated into Western culture, and "ghettoization" of Muslims in Western societies is self-inflicted rather than driven by adverse social, economic, and political factors.

While acknowledging differences in emphasis and focus within the clash literature, this article will analyze and critique prominent shared themes found throughout these books. Particular attention will be given to what might be described as the overarching narrative that informs the clash literature. According to this narrative, "the West" and Western liberalism embody humanity's

11 "The West" as defined by clash literature is implying both Europe and North America. However, some books specifically focus on Europe with America in the background. For this article, it is important to note that the influence of clash literature whether focusing on Europe and/or America extends from North America to Europe (especially since most of the authors are originally from North America). 
highest achievements, which are manifest in societies, structures, and norms that underscore individual freedom and political secularism. Rather than push Muslims and Muslim societies to adopt these ideals, however, Western elites have lost confidence in the fundamentals of their own traditions and succumbed to patronizing forms of "good will" and practices of political correctness, epitomized by policies that promote multiculturalism and ignore the pathologies of immigrant cultures. By opening the gates of society to large-scale Muslim immigration and failing to require assimilation, this approach has put Western and especially European societies on a path that will eventually lead to the demise of Western culture. Demographic factors linked to differential marriage and fertility rates will now lead to an inexorable decline or "slow suicide" of Western civilization as we know it. The only way to correct this decline and avoid a "last days" scenario, these authors suggest, is to assertively condemn Islamic culture and promote women's emancipation within Muslim communities.

After identifying and illustrating key themes of this narrative within multiple clash texts, analytical attention will be directed not so much to specific exaggerations and distortions inherent in this literature as to the overarching mode of argument and the way in which key themes are intended to speak to North American and European readers. Although there is no denying that many purveyors of clash literature have political motives [2-4] and are reproducing, in exaggerated form, classic tropes of orientalism [5] that run counter to much empirical evidence [6], the clash literature is also worth probing for what it reveals about contemporary "Western" identity insecurities. Clash authors rely heavily on pessimistic extrapolations and cherry-picked facts in ways that serve to advance a dehumanizing image of Islam and Muslims, all the while articulating a clear intent to sharpen polarization and dispel hope that relational engagement might transform or mitigate conflict. The fact that tendentious arguments purveying dehumanized enemy images have led to remarkable book sales should arouse concern. ${ }^{12}$ By taking contemporary identity insecurities seriously but not succumbing to discourse rooted in dualism, blame, or scapegoating, scholars who pause to reflect on the meaning of the clash literature have the potential expand academic as well as popular conversations. The very appeal of the clash literature points to a profound need for new arguments and visions - for accessible but not unsubstantial literatures that seek to stretch human imagination beyond the simplistic dichotomies and the reactionary impulses that have come to define the "post-9/11" era.

\section{The West as a Threatened Savior: Western Liberalism vs. Islamic Authoritarianism}

At the core of the new clash literature is an attempt to define Western values and identity in relation to - and at the expense of - a threatening Islamic "other". "The West" is portrayed as a fundamentally sound civilization, embodying the peak of idealism and human achievement, whereas Islam is characterized as a confounding diseased tradition that is rotten to the core. ${ }^{13}$

12 For commentary on the significance of dehumanization and enemy images with the context of identity conflict, see [7-9].

13 It is interesting to note that Muslim dissident reformist literature, which utilizes clash discursive tendencies, differs on this point. Such literature inherently advocates that Islam is not innately evil rather, Islam is worth saving and reform is essential for any transformation to occur. Much of this literature claims to be a "wake-up" call for 
Whereas the West is inherently benign, peaceful (there is no critique of colonialism and the imperial era), and focused on the liberation of human potential, Islam is equated with violence, an irrational drive towards world domination, and an absence of human liberty. For each attributed virtue or positive quality of the West, Islam provides an idealized foil or contrast. The West appears without the taint of historical errors or injustices, while Islam is essentialized as the West's antithesis, or shadow.

Robert Spencer, a prominent conservative blogger who has been officially banned from Britain for his provocative advocacy against Islam [12], articulates this approach to contrasting Islam with the West in quite vivid terms. In his Religion of Peace?: Why Christianity Is and Islam Isn't, Spencer argues that the core of Islam, including Sharia laws, is built on the fundamentals of violence and domination. He therefore urges all other religious orders to align against this "common enemy" of "Islamic supremacy" ([13], p. 204). In making such arguments, Spencer and most other clash authors establish a fundamental distinction between their own discourse and arguments made in conventional post-9/11 anti-terrorism discourse. Whereas the former asserts directly that Islam is fundamentally flawed in ways that predispose followers toward violence, the latter differentiates between extremist and mainstream positions within the Muslim community. ${ }^{14}$

A related theme of clash literature is that, despite the obvious hostility of Islam and Muslims, most Westerners are unaware of the gathering danger posed by Islamic infiltration of European and North American societies. As Bruce Bawer argues in Surrender: Appeasing Islam, Sacrificing Freedom, "We in the West are living in the midst of a jihad, and most of us don't even realize it..." ([15], p. 3). Bawer proposes that because violence and Islamic supremacy are intrinsic to the Islamic faith, Muslims living in the West are necessarily engaged in jihad to dominate Westerners and deprive them of individual freedom. To lend credence to this position, he utilizes individual stories of trauma and pain in which Islam can be identified as the perpetrating factor.

Like many fellow authors within the clash literature, Bawer draws heavily on the writings of Ayaan Hirsi Ali, a best-selling Muslim "dissident" and controversial former Dutch parliamentarian who now resides in the United States. Hirsi Ali attributes much hardship and suffering to her fundamentalist upbringing as a Somali migrant whose family settled in Kenya. Her early Islamic education was heavily influenced by Wahhabi or puritanical forms of religious interpretation, and she extrapolates from examples derived from her own experience of conservatism within a particular branch of Muslim culture to arrive at negative conclusions concerning the whole of Islam. She describes her Dutch education in Enlightenment thinking as a liberating force in her

Muslims. One prominent example in this literature is Asra Nomani's Standing Alone in Mecca: An American Woman's Struggle for the Soul of Islam [10]. For a comparison of this literature to the clash literature analyzed in this article please see my forthcoming manuscript, Controversies, Clichés, and Conversations: Islam, Muslim Women, and the Negotiation of Identity in Contemporary North America [11].

14 Spencer is a charismatic speaker and author who received his Masters in Religious Studies at the University of North Carolina. He has published twelve books specifically on the Islamic threat to Western society, and is currently the director of Jihad Watch, an Internet blog designed to monitor and report subversive Islamic theology and action. He also has participated in numerous seminars for American military groups (i.e., United States Central Command, United States Army Command and General Staff College, the U.S. Army's Asymmetric Warfare Group, the FBI, the Joint Terrorism Task Force, and the U.S. Intelligence community) [14]. 
own life, particularly after the violent incidents of September 11, 2001. Having faced deeply threatening reactions to her personal liberation from Islamic conservatism and her growing political activism, she generalizes about Muslim immigrants in Western countries and argues that they pose a grave threat to the social and political fabric of these countries. Western institutions and individuals, she asserts, need to stop supporting the preservation of foreign cultural values, particularly those derived from Muslim cultures. Instead of multiculturalism, the emphasis should be put on replacing Islamic ways of thinking and living with alternative values derived from the European Enlightenment: democracy, individual freedom, and gender equality. Once again, Islam and the West are presented as antithetical wholes with diametrically opposed ideals and values. Where Islam suppresses the individual and subjugates women, the West liberates. Where Islam teaches dogmatism, authoritarianism, and ideological closure, Western rationalism promotes freedom of thought, choice, and opportunity.

Personal narratives of oppression and liberation from figures such as Ayaan Hirsi Ali as depicted in her best-selling books (i.e., Infidel and Nomad) are central to clash literature, providing personal traumatic testimonials from disaffected Muslims to back up larger, more abstract arguments. The following passage from Bawer is illustrative:

In response to the common criticism that Hirsi Ali is inappropriately disrespectful toward Muslims: "Why should anybody be expected to respect a religion that demands his or her submission, subordination, or even execution?" ... As for 'insulting'-well, exactly who is insulting who? It isn't as if European Christians and Jews are running around raping Muslim women, defacing Muslim cemeteries, shooting bullets into the facades of Muslim houses of worship, and tormenting Muslim children in school ([15], p. 139).

Treating those who threatened Hirsi Ali for her advocacy against Islam and Muslims as the authentic representatives of the religion itself, Bawer does not hesitate to hold Islam as such responsible for the negative dynamics of her particular life experiences. Having ascribed guilt to Islam in general, he then asserts the innocence of Western and specifically European parties vis-à-vis Muslims. Leaving aside the events of the former Yugoslavia during the 1990s, when behaviours such as those described by Bawer did in fact take place, the mode of argument manifests strong elements of provocation, and can be understood to imply that the Islamic religion begets offences that are presumably alien to the Christian and Jewish experiences. Insofar as historical analysis reveals that abusive behaviours in the name of Christianity and Judaism have occurred in a manner not unlike those attributed to Islam, a discerning reader could easily receive the impression that the eagerness to generalize darkly about Islam and Muslims is at least in part driven by a psychology of projection and a desire to refuse confrontation with past ghosts of the Western experience, including "religious" wars and various ways in which individual and women's rights were denied or suppressed.

This inability to articulate the complexity of the Western experience, and the manner in which the story of "the West" (insofar as one can be told) is very much a struggle for "Western" solutions to "Western" problems, is intimately linked to attitudes toward Islam that some critics would describe as neocolonial. If the West represents the fulfillment of humane values, and if it is itself devoid of a shadow side, why should the West not also be the primary vehicle for saving benighted 
societies that lack indigenous virtues and credible wellsprings of internal reform? Such thinking about Western superiority and the need for Western victory in a cultural war with Islam is an explicit theme in Hirsi Ali's writings as well as in the clash literature more generally. Throughout, there is an equation of the West with freedom and Islam with incarceration. The following passage from Hirsi Ali is illustrative:

When I'm told to be careful not to impose western values on people who don't want them, I beg to differ. I was not born in the west and I did not grow up in the west. But the delight of being able once I came to the west to let my imagination run free, the pleasure of choosing whom I want to associate with, the joy of reading what I want, and the thrill of being in control of my life — in short, my freedom — is something I feel immensely as I manage to extricate myself from the shackles and obstacles that my bloodline and my religion imposed ([16], p. 242).

In Hirsi Ali's view, the Western story of human emancipation through reason and education can unshackle Muslim societies just as it liberated her own imagination. She calls upon schools and universities to "openly challenge the beliefs of Muslim children and their parents" and help them to cast off Muslim "self-imposed blinkers" ([16], p. xix). The West holds an antidote to superstition, poverty, and tyranny, and should vigorously seek to win a cultural war against Islam: "There is already a clash, and we are in some sense already a war. That western civilization is superior is not simply my opinion but a reality I have experienced and continue to appreciate everyday. I assume that the west will win. The question is how" ([16], p. 245). Such arguments articulate quite succinctly key elements of the worldview present within the clash literature: two civilizations are locked in struggle, one based on reason and the other rooted in religious law and stifling superstitions. The superior civilization must confidently pursue victory over the lesser civilization, but to defend its gains and to liberate those shackled by centuries of religious obscurantism.

\section{The Denial of Muslim Moderation}

To maintain this vision, writers of clash literature need to persuade readers that Muslims are far more alike than unalike, and that they cannot be trusted either to harmonize with Western social norms or implement their own religious reformation. Many are quite blunt in asserting that, though Muslims may differ somewhat in the means that they choose, there are not significant differences between the goals of mainstream Muslims and those of terrorists. Mark Steyn, author of the 2006 New York Times bestseller, America Alone: The End of the World as We Know It, states that, "A large majority of Western Muslims support almost all the terrorist's strategic goals." He substantiates this by citing a poll in which "over 60 percent of British Muslims" articulated a desire to "live under shari'a in the United Kingdom" ([17], p. 76). Though this is certainly an unsettling statistic for many non-Muslims, its significance is less obvious than Steyn implies, given that Muslims differ quite profoundly in their understandings of sharia, and a desire among many to make their personal lives (particularly matters such as marriage, intimate relations, funerals, and divorce) compliant with traditional Islamic norms need not necessarily imply a totalizing theocratic threat to the Western way of life. Like statistics concerning the number of Americans who question evolutionary theory or who believe end times are imminent, the number cited by Steyn does not immediately lend itself to a definitive, let alone alarming, interpretation. Sounding an alarm is, 
however, a quite definite intention behind works like America Alone. Steyn's book addresses the relationship between America, Europe, and Islam. Writing within the overall context of the global war on terror, Steyn places particular weight on recent demographic statistics signalling population trends in Muslim and non-Muslim countries: Muslim immigration, birth rates, fertility rates, and marriage rates. He darky raises the prospect that Europe will fall to Muslim domination, leaving only America to uphold Western values in the face of a Muslim opposition that lacks true moderates. The text, incidentally, was recommended by former U.S. president George W. Bush to his staff. ${ }^{15}$

For Steyn and other clash authors, the West has no trustworthy allies within the Muslim world, except for those who place themselves on or beyond the outer margins of Islamic faith and belief. Creating a vision within which an authentic Muslim cannot truly be moderate, they portray Islam itself as an extreme religion that prevents assimilation and compromise. Those who seek to paint a different picture of an Islam that is dynamic and flexible or endowed with positive values are discounted as "apologists."

A writer known as Ibn Warraq in his Why I am Not a Muslim, himself reputedly a former Muslim, dismisses those who represent Islam positively and equates Islam with the worst events in Muslim history, which are presumably far worse in magnitude than persecutions organized by followers of other religions.

Apologists of Islam still insist on perpetuating the myth of an Islam that accorded equality to her non-Muslim subjects: they talk of a time when all the various religious communities lived in perfect harmony in the Islamic lands. The same apologists minimize, or even excuse, the persecution, the discrimination, the forced conversions, the massacres, and the destruction of the churches, synagogues, fire temples, and other places of worship ([18], p. 214).

For Ibn Warraq, as for other clash authors, Islam is an exception in the domain of religions, intrinsically intolerant and aggressive. Implicitly, Muslims who insist otherwise are either being dishonest or else they are not truly Muslims.

Many clash authors appear to favour the former interpretation, that so-called "moderate Muslims" are actually hiding the extent of their support for radical Islamic ends. Rhetorically, Steyn attacks the credibility of his intellectual opponents by associating their views with those of terrorists. The language is inflammatory, and seeks to discredit all Western Muslim commentators as potential enemies within: "Given the very few degrees of separation between very prominent Western Muslims - ambassadors, princes, professors - and the terrorists, it seems likely that many prominent figures in these parties will be supportive of terrorists ends" ([17], p. 204). Bawer uses a similar approach to characterize his adversaries, suggesting that even the most "assimilated" or liberal of Muslims living in the West harbour elements of the Islamic worldview, which, by their nature of being Islamic, clash irreconcilably with those of the secular Western worldview. "No, there's no guarantee," states Bawer, “that western Muslims, in meaningful numbers, will ever

15 It is important to note that Steyn is a Canadian-born writer, political commentator and cultural critic. Steyn often writes articles for the most popular Canadian journal, Macleans. In 2007, the Canadian Islamic Congress filed human rights complaints against Maclean's Magazine for publishing eighteen "Islamophobic" articles by Steyn to the Canadian Human Rights Commission. The Commission dismissed the complaints in June 2008. 
openly and actively champion freedom and defy jihadists; to do so, after all, is alien to every value with which many of them were raised" ([15], p. 276).

Hirsi Ali similarly discounts the notion of Muslim moderation, focusing particularly on what she sees as the inherent contradictions of this position. Because Islam, in her view, is scripturally wired for immoderate beliefs, an authentic Muslim cannot truly be "moderate" or "modern." Writing as if a large number of moderate, educated, and religiously dedicated interpreters of Islam did not exist, Hirsi Ali proposes that Muslim insistence on basic articles of faith such as the inspired nature of the Qur'an precludes intelligent reflection on the meaning of scripture for today:

A moderate Muslim does not question Muhammad's actions or reject or revise parts of the Quran. A moderate Muslim may not practice Islam in the way that a fundamentalist Muslim does-veiling, for example, or refusing to shake a woman's hand-but both the fundamentalists and the so-called moderates agree on the authenticity and truthfulness and the value of Muslim scripture ([16], p. 195).

In making this argument, Hirsi Ali chooses to ignore the vast differences in position taken by Muslims of differing ideological and interpretive dispositions, and demonstrates a lack of awareness that even so-called fundamentalists interpret their religious sources.

Significantly, the pronouncements of clash authors are themselves based on an interpretation of Islam - an interpretation that equates religious extremism with religious authenticity. Robert Spencer's proposal for a religious alliance against Muslims to defend the West reveals this quite clearly:

Islam seeks the conversion, subjugation, or death of not only Christians but also all-non-Muslims. Thus it is imperative that all the victims or potential victims of Islamic jihad-Christians, Jews, Buddhists, Hindus, atheists, secular Muslims, and all others-recognize that...we must all hang together, or we shall indeed hang separately ([14], p. 10).

For Spencer, the beliefs of the most extreme and inflexible Muslims are to be taken as normative, while the beliefs of others are discounted and treated as either insincere or insignificant. Islam, he proposes, cannot accommodate moderation, and must be resisted.

Some authors of clash literature affect a less strident and more nuanced attitude toward Islam, while conveying a generally negative evaluation of the religion and its adherents. Christopher Caldwell, Senior Editor at The Weekly Standard and a regular contributor to the Financial Times, casts serious doubt on the Muslim capacity for adaptation, and points to disproportionate incarceration rates among European Muslims ([19], p. 135). In his popular book, Reflections on the Revolution in Europe, skepticism about Islam is conveyed more indirectly and with greater subtlety:

Reaching out to so-called "moderate Muslims" is the cornerstone of European strategy against terrorism. Moderate Muslims are the people who can be trusted not to "distort Islam", or at least to distort it is a positive way-by building a "European islam" that can interact with the continent's political institutions without breaking them ([19], p. 283).

By inserting the adjective "so-called" before the term "moderate Muslims" and using a lowercase letter for "European islam," Caldwell casts doubt on the authenticity of accommodating Muslim responses to Western culture and institutions. In the clash literature, the mark of authenticity is applied to forms of Islamic practice that appear most incompatible with the idealized Western model with which they are compared. 


\section{Demise of the West: Muslim Demographics and the Loss of Faith}

Demographics are a salient theme in a variety of clash texts, and one of the primary areas in which the authors perceive the West to be vulnerable. Drawing upon a variety of trajectories, projections, and conjectures, the authors paint a picture in which Muslims gradually overcome their non-Muslim counterparts, particularly in Europe, and achieve by high immigration levels and birthrates what they could not accomplish by military means: a "Muslim Takeover" of Europe. They accomplish this "Takeover" with the complicity of liberal elites attached to welfare and multicultural policies that impede assimilation and foster an atmosphere of political correctness that stifles protest.

Concern about new classes of immigrants who cannot be assimilated is by no means a new phenomenon. In the United States, large-scale immigration of Catholics from Ireland and southern Europe generated great anxiety in the late $19^{\text {th }}$ and early $20^{\text {th }}$ centuries, leading to arguments about fertility rates and questionable religious loyalties that parallel those made about contemporary Muslim immigration to Western contexts. ${ }^{16}$ The validity of such comparisons is not obvious to clash authors, however, who view the opening of immigration to Muslims through a dark lens.

In Decline and Fall: Europe's Slow-Motion Suicide, Bruce Thornton goes so far as to describe Europe's accommodation of a Muslim presence as "suicide by immigration"-not just resignation in the face of an "invasion" ([20], p. 80), but "a complete capitulation and betrayal of Western civilization" ([20], p. 80). This betrayal reveals the extent to which "cultural toxins" have infected the West since WWII, especially "fashionable self-loathing guilt over supposed Western crimes like racism, imperialism, colonialism." This guilt weakens Europeans and emboldens "invaders" ([20], p. 80).

Christopher Caldwell's language is less pointed, but advances similar undertones of Muslim invasion. When Europeans opened their doors to mass immigration in the wake of World War II, they began a monumental experiment without any consideration of the long-term consequences or "hidden costs". As a result, the face of Europe is changing:

Muslims now either dominate or vie for domination of certain important European cities.... Such places may, as immigration continues and the voting power and political savvy of the Muslims already there increases, take on an increasingly Muslim character ([19], p. 118).

As soon as it became obvious that certain immigrants proposed to establish foreign cultures on European lands, immigration - and Muslim immigration a fortiori - appeared in a different light. It appeared in the light of a project to claim territory ([19], p. 132).

Using government statistics, social surveys, think-tank reports, novels, and newspapers in eight different languages, Caldwell argues that changes are underway that will fundamentally change the character of the European experience, providing lessons in failed government policies that have increased the challenge of merging newcomers who were already resistant to assimilation into the continent's established cultures and values.

16 For more about this comparison see reference 6 . 
Walter Laqueur's The Last Days of Europe: Epitaph for an Old Continent explores similar themes, but with added emphasis on the unplanned and uncontrolled nature of Muslim immigration, as well as on what he regards as the dysfunctional impact of welfare policies. Like Caldwell and other authors, he bemoans the fact that Europe's once predominant place in the world is a thing of the past. Continued decline, he suggests, appears inevitable; changes in the European landscape associated with the large influx of Muslim immigrants are both a consequence of this decline and a major contributing factor. ${ }^{17}$

Laqueur points out that the first wave of immigration had much to do with the dissolution of Empires (e.g., West Indians, Pakistanis, Indians from India, and Indians from Uganda going to the United Kingdom; North Africans migrating to France) and was generally assumed to be a temporary phenomenon regulated by work permits. Many of these immigrants, however, managed to stay on legally or illegally, "and the host governments were not willing to enforce the law against those who broke it." Thus, major foreign communities were developing in Europe at the same time as the oil crisis of 1973, which reinforced trends toward high unemployment ([21], pp. 34-35). The growth of Asian, African, and Middle Eastern immigrant communities, then, had less to do with genuine opportunity than with high birthrates, success in bringing dependents to Europe (legally or illegally), the transformation of illegal immigration into an organized business, and the proliferation of asylum seekers fleeing imprisonment or political turmoil. To underscore the rapid pace of population growth and its transformative impact, Laqueur cites a variety of data that indicates the doubling and tripling of Muslim communities across Europe since 1980s-2006 ([21], pp. 36-37).

In Laqueur's view, these changes bode ill for the future of Europe, for a variety of reasons. In addition to the fact that many immigrants have been unable to find steady and gainful employment, European countries were not well prepared to absorb large-scale immigration by foreigners emanating from wholly different cultures ([21], p. 170). Though Laqueur does not go so far as Bawer in emphasizing undesirable values held by new immigrants who were not prepared to play by established rules and respect European institutions, ${ }^{18}$ he does suggest that European countries were to some degree taken advantage of by immigrants whose primary motivations were economic, and whose ranks included a criminal element:

...[E]ven though the majority of these immigrants, probably the great majority, were not political refugees but economic immigrants in search of a better life for themselves and their children. Among the political asylum seekers there were islamists or even terrorists who were indeed in danger of being arrested in their native countries, but for reasons that had nothing to do with the struggle for democracy and freedom...also asylum seekers were criminals and came to establish criminal gangs ([21], p. 35).

In permitting large-scale immigration, therefore, European nations allowed the infiltration of Islamists, terrorists, and others who were in danger of being arrested in their own countries. The

17 Other factors in Europe's decline include the stalling of the movement toward European unity and the crisis of the welfare state, as well as a European crisis in self-confidence that is both a contributor as well as a result of these factors.

18 Bawer states "Most come from poor villages in underdeveloped countries with high levels of corruption-a background that tends to breed cynicism, duplicity, and an exceptional skill at manipulating the system" ([1], p. 30). 
latter established criminal gangs specializing in the drug trade, prostitution, car, and other illegal activities in their new home countries. A significant proportion of the immigrants came to depend on European welfare services "from the day of their arrival." State authorities should have instead directed them to "productive labour" ([21], p. 172). Laqueur finds it particularly upsetting that some Muslim immigrant religious leaders were inclined to incite their followers "against the decadent and sinful Western way of life" and believes these figures should have been deported. "They should have been expected to behave in accordance with the law of the land and the values and prevailing norms. If these laws and norms were not according to their convictions, they would have been free to leave." ([21], p. 172).

Steyn's treatment of this subject echoes that of other clash authors, underscoring Europe's low birth rates and generous welfare state. These factors have weakened the continent and made it dependent upon immigrants, largely Muslims, to work and maintain the social benefits for the elderly non-productive social sector. The European "nanny state" has therefore played a central role in transforming Europe into "Eurabia." Even as many immigrants work to support the welfare state, however, many others become dependent on its services in ways that support the maintenance of state-subsidized enclaves that cannot assimilate to mainstream culture.

Thornton agrees with Steyn that Europe impedes the progress of immigrants is by lavishing welfare benefits on them, and further elaborates on the idea of "Eurabia" by drawing on Bat Ye'or's definition of the term: "Europe's evolution from a Judeo-Christian civilization, with important post-Enlightenment secular elements, into a post Judeo-Christian civilization that is subservient to the ideology of jihad and the Islamic powers that propagate it." Thus, again borrowing from Bat Ye'or, Europe is becoming a "civilization of dhimmitude" ([20], p. 90) - that is a civilization that is being subservient to Muslim rule. Thornton associates this condition with the decline of Christianity and Europe's failure to protect Western Christianity:

In the past, Europe's resistance to Islamic imperial ambition was fired by Christian faith... But having abandoned God and country, where will Europe find the spiritual resources to assert the rightness of the Western civilization Christianity helped to create, and fight back vigorously against those who wish to destroy it? ([20], p. 130)

In Thornton's account of the situation, secularism has created a politics void of religious conviction. In the absence of such conviction, the void is being filled by outsiders, hostile to Europe's unique religious heritage.

Intriguingly, this call to respect and protect Europe's Christian heritage finds an echo in Ayaan Hirsi Ali, herself an atheist. Hirsi Ali calls on Muslims to learn from and perhaps convert to Christianity, largely on account of modern, post-Enlightenment Christianity's superior treatment of religious dissenters.

I would by far rather live in a Christian than a Muslim country. Christianity in the West today is more humane, more restrained, and more accepting of criticism and debate. The Christian concept of God today is more benign, more tolerant of dissent. But the most important difference between the two civilizations is the exit option. A person who chooses to opt out of Christianity may be excommunicated from the Church community, but he is not harmed; his destiny is left to God. Muslims, however, impose 
Allah's rules on each. Apostates - people, like me, who leave the faith — are supposed to be killed ([16], p. 244).

Hirsi Ali goes on to represent the involvement of Christian groups as perhaps the most crucial element in integrating Muslim immigrants and stopping the spread of radical Islam: "the clash of civilizations can be won through religious competition" ([16], p. 253).

Virtually all clash authors blame the West for lacking an appropriate strategy to deal with Muslim immigration; some also credit Muslims for having a dangerously coherent and effective strategy for infiltrating and asserting control over Western nations. William Wagner's How Islam Plans to Change the World is such a text. "In analyzing the Muslim strategy," Wagner states, "I have come to the conclusion that they have a three-pronged plan, which is as follows: jihad, daw'ah, and mosques." ([22], p. 12) According to Wagner, ${ }^{19}$ Islam becomes a threat and danger to the entire Western world and more importantly the Christian world, through their forms of proselytization, holy struggle and visibility. Wagner refers to Islam as a more or less unified and monolithic entity driven a drive for world domination: "In the search for world dominance, Islam will use truth as they understand it even if it conflicts with the Christian understanding of the term...Both the concepts of truth and fear have proven to be helpful in the overall Islamic strategy" ([22], p. 136, italics added).

Wagner dedicates a whole section of his book to the Islamic process of da'wah, or missionary work. One of his key concerns is that Christians are not competing vigorously enough with their Muslim counterparts.

These 'propagators' also carry the title of being daa' $i$. Sometimes these Islamic missionaries are fully funded.... Most likely, there are more daa'is preaching Islam in the West than there are missionaries in the Muslim countries preaching Christianity ([22], p. 42).

Though Wagner believes Christians are falling behind Muslims in the missionary enterprise, he remains convinced that Christian missions are morally superior to Islamic da'wah, and dedicates an entire section within his text to the differences between the two religious approaches. One of the contrasts, for instance, is the greater Christian emphasis on charitable enterprises: "Christian Missions engages in the establishment of schools, hospitals and other benevolent institutions through cooperative methods" whereas "Islamic Da'wah stresses the construction of a mosque and then establishes its ministries" ([22], p. 44). This argument is pitched toward a relatively narrow audience and neglects to acknowledge the very extensive social services provided by Muslim revival organizations within Muslim-majority societies, but provides insight into how some Western Christian groups perceive interreligious relations within the context of the broader clash literature. ${ }^{20}$

19 William Wagner is a Baptist missionary and a professor of missions at the Golden Gate Baptist Theological Seminary.

20 Whereas most of the books cited in this paper were published by mainstream, non-religious presses, Wagner's text was produced by a Christian publisher dedicated to missionary work. Kregel Publishers, the publisher of Wagner's text, mission statement reads, "Our mission as an evangelical Christian publisher is to develop and distribute...trusted, biblically based resources that lead individuals to know and serve Jesus Christ." [23] 


\section{Failure of Muslim Immigrant Assimilation}

According to most clash authors, the failure to assimilate Muslim immigrants is the Achilles heel of Western civilization. The following quotes are illustrative:

[T] he spectacular failure of integration has brought some nations to the verge of social chaos and is leading others steadily in that direction ([24], p. 233).

The European failure to assimilate immigrants, as Timothy Garton Ash notes, may contribute to a "downward spiral which will be the curse of the national politics of Europe for years ahead...." Immigrant Muslim youth will increasingly become involved in Islamist extremism and outright terrorism, as happened in Madrid and London, thereby reinforcing native-born resentments and fears ([20], p. 45).

Almost without exception, contemporary clash authors paint a highly pessimistic picture of Europe's future, within which youth riots and incidents of delinquency and terrorism become ever more frequent.

Notably, clash authors steer clear of in-depth sociological analysis. Many thinkers who frame their analysis in terms other than those of the clash literature have argued that failures of integration are at least to some extent caused by barriers within European societies, which for decades desired guest workers for economic reasons and yet created legal as well as social obstacles to citizenship and full participation. Marginalization was therefore an outcome of specific policy choices, and inability to overcome job discrimination or invest appropriate resources. Clash authors, however, take the position that European nations have been far too accommodating. Laqueur, for example, argues that individual European citizens "had never been asked whether they wanted millions of new neighbors in their country... [and] about this very essential issue no one had ever consulted them" ([21], p. 171). As a result, European governments and societies found themselves in a position in which they were unable to provide guidance to newcomers but were instead "highly permissive." Social and political elites had lost their self-confidence; among the establishment, cultural and moral relativism rather than pride prevailed. Thus "newcomers to these countries were bound to gain the impression that prevailing laws and norms could safely be ignored" ([21], p. 172). Caldwell amplifies this point about ignoring prevailing Western norms and laws, stating that, "Islam in Europe is different." "Since its arrival half a century ago," Caldwell states, "Islam has broken or required adjustments to or rearguard defenses of a good many of the European customs, received ideas, and state structures with which it has come in contact." ([19], p. 13).

In addition to the general concerns about the failure of assimilation, the ghettoization of European Muslims is a major concern of clash thinkers. A number of authors stress that this condition is self-imposed by the Muslim community, and that religious leaders are particularly culpable. In these respects, Muslims are perceived as different from other ethnic communities:

Muslim newcomers apparently like to stick longer with their coreligionists than do other groups of immigrants, and they are encouraged by the preachers to do so. This is true even with regard to India, where there is more ghettoization than in Europe; even middle-class Muslims seem to be reluctant to leave the areas where members of their community live ([21], p. 42). 
Muslim religious leadership has a vested interest in keeping Muslims in ghettos because it allows them to have better control in ensuring that "there is little, if any, contact between the faithful and the infidel." ([21], p. 206)

Of central concern is that areas of concentrated Muslim settlement become intensely conservative and resist cultural influences from the larger society. Most authors express concern that these new Muslim ghettos are "breeding grounds" with major demographic consequences, as reflected in high marriage and fertility rates. Because these rates are significantly higher than in the general population, the authors express grave concern Europe will be overwhelmed demographically from within, and not only in comparison to other world regions with rapidly growing populations.

It is against this backdrop of stated concerns that Steyn proclaims his thesis that, as central as America may be saving the world, concerted action is now necessary to save America. Calling his production "a doomsday book with a twist" ([17], p. 15), Steyn uses demographics to demonstrate Europe's inept and suicidal social politics, and to warn Americans about Europe's demise. He wants America to resist gradual "Islamization" that has penetrated the developed lands of Europe. In his view more Muslims in Europe correlates directly with more terrorism, honour killings, and polygamy, and inversely with individual and political freedom. To save America from such a fate, it must refashion its traditional role as the land of opportunity for newcomers, and avoid giving minorities too many rights. America, he proposes, is the West's last chance, and faces nothing less than an ideological war to preserve the "Western way of Life".

\section{The Problems of Political Correctness and Multiculturalism}

Another central theme of the clash literature is that Western elites have betrayed their mother culture, by indulging in excesses of self-criticism and self-doubt. These habits of thought and intellectual attitudes have led to an under-valuation of Western culture and to the rise of multiculturalism, which has been exploited by a Muslim adversary who benefits from pluralism without practicing it in relation to others. As the West now faces a powerfully motivated and implacable foe, clash authors assert, the West needs to recover faith in its past greatness and cultural heritage, as well as its willingness to engage in critique of other cultures.

Robert Spencer blames political correctness for current problems. Building on Bernard Lewis's judgment that Europeans "have no respect for their own culture," Spencer argues that political correctness has led to a double standard according to which the majority culture and religious traditions affiliated with this culture are subjected to scholarly and societal criticism:

Americans and Europeans...need to stop apologizing for all our forefathers allegedly and actually did wrong, and for the culture they built and remember what they did right, recognizing what Judeo-Christian civilization has brought to the world ([13], p. 3).

Rather than focus guiltily on historical misdeeds committed in the name of culture and religion, Spencer proposes, Western education and social commentary need to restore a sense of cultural pride or patriotism to collective consciousness. Without such a shift to a different way of being, Spencer believes that the West will ultimately lose the "War on Terror" ([13], p. 4). 
Closely associated with this theme of political correctness is the idea of moral equivalency. Clash authors argue passionately in favour of Western moral superiority vis-à-vis Islam, and accuse Western elites of fostering a false perception that all religions and cultures are equal. Spencer, for example, argues that the present state of society and academia in the West has permitted the rise of a perception that Islam is "morally equal" to Christianity ([13], p. 1) - a perception with which he emphatically disagrees. Whereas an attitude of moral equivalency conceals the flaws of immigrant Muslim culture, respect for Western values demands an unwavering critique. Gilles Kepel elaborates on this point, specifically arguing that it was "the multicultural elite [who] was, almost without exception, allied with the Islamic right... [in] explaining away delinquency, suppressing reports of violence, standing up for the hijab, and so forth." ([24], p. 212) Multiculturalism, this logic proposes, leads elites to stand up for the "other" even when the practices of this other are not acceptable in light of modern societal standards.

Bawer argues that Muslims pose a grave threat to liberal values in the Western countries where they live. The inability of Western leaders to uncompromisingly assert the priority of these values over the dictates of multiculturalism (which forces compromise with the Muslim immigrants' expectations), may be the factor that will ultimately result in the demise of Western liberal values. Bawer is especially concerned with what he perceives as the vulnerability of the right to free speech, and believes Western countries have taken too accommodating a response to Muslim offences during the past two decades, including rioting, death threats against critics, and murders of non-Muslims.

Free speech is in a crisis. To respond with the "accommodation" recommended by so many journalists, politicians, and intellectuals would be simply to submit to abandon freedom, embrace dhimmitude, and hope for the best from our new overlords ([15], p. 276).

For Bawer, multiculturalism is an evil that has forced Westerners into complacency with foreign cultural norms. It has blinded intellectuals to the threat that Islam poses to Western democracy, while simultaneously empowering Muslim immigrants and allowing them to resist adaptation to the ideals of the Enlightenment. To put the matter in even stronger terms, it has enabled Muslims to wage cultural warfare against the West from within the heart of Western societies. In Bawer's view, Muslims living in the West are engaged in a "cultural jihad" and will stop at nothing to bring the West into the "House of Submission", or "Dar al-Islam" ([15], p. 3). Bawer alleges that "the pernicious doctrine of multiculturalism" motivated non-Muslims to support Muslims in targeting Salman Rushdie, as multiculturalism "teaches free people to belittle their own liberties while bending their knees to tyrants... which... has proven to be so useful to the new brand of cultural jihadists that it might have invented Osama Bin Laden himself” ([15], p. 5).

A similar polemic against multiculturalism appears in Ibn Warraq's Why I am Not Muslim. According to Ibn Warraq, multiculturalism has lowered cultural defenses and enabled newcomers to make excessive demands. He equates multiculturalism with one or two attitudes with respect to human values - a false universalism or a harmful relativism:

The implications of Muslim demands on the wider British are enormous. Unless great vigilance is exercised, we are all likely to find British society greatly impoverished morally, and all the gains, social and moral, may well be squandered in an orgy of multicultural liberalism ([18], p. 353). 
Multiculturalism is based on some fundamental misconceptions. There is the erroneous and sentimental belief that all cultures, deep down, have the same values; or if these values are different, they are equally worthy of respect. Multiculturalism, being the child of relativism, is incapable of criticizing cultures, of making cross-cultural judgments. The truth is that not all cultures have the same values, and not all values are worthy of respect ([18], p. 356).

At the core of this argument is the contention that Muslim values overlap very little with Western liberal values, and that multicultural tolerance is one of the central factors perpetuating certain practices that are especially problematic from a Western liberal point of view. Rather than an attitude of respect and dialogue which invites reciprocity and coexistence, Ibn Warraq sees in multiculturalism and inability to engage in critical thinking, as well as a racism of low expectations: "Multiculturalists are incapable of critical thought, and in a deep sense are more racist than the racists they claim to fight" ([18], p. 354).

Bruce Thornton's Decline and Fall embellishes on this theme of multiculturalism as a key causal factor preventing assimilation. Thornton's overarching thesis is that Europe is becoming "Eurabia" due to "cultural toxins" imported by Muslim immigrants. This process is facilitated by a doctrine of multiculturalism that permeates the thinking of Western elites. The essence of multiculturalism is not the call to recognize and respect the value and contributions of other cultures, something that he believes the West has been doing for centuries. Rather, openness to the cultural 'other' and willingness to criticize one's own ways has degenerated into a naïve idealization of the non-Westerner and a corresponding hatred of the West ([20], p. 96).

Thornton explains that modern multiculturalism in the West began with Europeans admiring the "noble savages" they encountered, including American Indians, South Sea Islanders, Africans, and Arabs. These peoples seemed to embody a simpler, more humane existence that the West had abandoned in its pursuit of power and profit. This is seen in the Romantic complaints such as the following by Wolfgang von Goethe in 1828:

We other Europeans are ailing. Our styles of life are far from the healthy state of nature, and our social relations lack charity and benevolence. ... I often wish I were one of those so-called savages born in the islands of the South Seas, so that at least once I could savor human experience in its purity, without some artificial aftertaste ([20], pp. 97-98).

Thornton contends that such attitudes have dominated the art and literature of the West for the last two centuries, eroding cultural certainty and self-confidence.

Another key factor in Thornton's critique of elite attitudes that have undermined the West is Marxism. He notes that, like the Romantics, Marxists similarly complained about the West in their writings on the destructive effects of industrial capitalism, which Marx himself represented as a system which had replaced the humane, organic relations between people with the alienating, dehumanizing power of the contract, private property, wage labour, and the profit motive ([20], p. 98). Such assumptions, Thornton alleges, caused the West to give more credit to pre-capitalist non-Western societies than was warranted. Idealization of the non-West also found reinforcement in later Marxist analyses of imperialism and colonialism. This led to the idealization of the Third World as "history's instrument for transforming the wicked West; because of this, resistance to 
immigration, demands that immigrants assimilate to their new homes, and expressions of national pride have all become 'fascist', tainted with Nazi racism and the Holocaust" ([20], pp. 99-100).

Echoing many other conservative thinkers and clash theorists, Thornton argues that Western intellectual elites have destructively wedded themselves to "self-hating" ideas. Leftists, he believes, have used naïve idealizations of the Third World as the basis for pursuing the liberation of the oppressed, while ignoring the very brutal imperialist ambitions of the Soviet Union as well as the current expansionist ambitions of jihadists. The currently reigning mode of thought is "Third Worldism," the doctrine that "every Westerner is presumed guilty until proven innocent" ([20], p. 100). The way of thinking is the product of a combination of noble-savage idealism and Romantic discontent with Marxist-Leninist theorizing and post-Marxist multiculturalism. The result is a suicidal self-hatred among many Westerners, who, convinced of their guilt, do not have the cultural resources for defending their way of life: "These days, the successor of Europe is Eurabia” ([20], p. 101).

Because of multiculturalism, then, Muslim immigrants have been allowed to perpetuate their cultures no matter how alien to the values of western civilization even as the European nations make it difficult for those who wish to assimilate. Immigrant communities are allowed to create their own standards of behavior, educational curricula, social mores, and public practices, indulgences not allowed native born-citizens of host countries ([20], p. 101).

Multiculturalism, then, creates too much space for difference. To back up this claim, Thornton uses the following examples:

- In Sweden, the legal age of marriage is 18 , but for immigrants there is no minimum age.

- Turkish and Pakistani immigrants in Germany are exempted from the usual intrusive procedure that a German who wishes to marry someone not from an E.U. member state has to undergo in order to prove that the relationship is legitimate, on the assumption that their marriages are arranged.

- In France, public swimming pools are segregated by sex to appease Muslim sensibilities.

- Some British retailers have stopped selling mugs that depict the character Piglet because Muslims find pigs offensive.

- Burger King's chocolate ice cream swirls were banished in some places because they reminded Muslims of Arabic writing.

- After the murder of Theo Van Gogh, Dutch schoolchildren were not allowed to wear Dutch flags on their backpacks lest Muslims find them provocative ([20], pp. 101-02).

Thornton categorically rejects the notion that at least some bias towards Muslim immigrants is based on prejudice and ignorance. He characterizes "Islamophobia" as a new thought-crime, a variation on the "racist" charge used by multiculturalists to forestall criticism or silence those who speak of uncomfortable facts. Such oversensitivity, he proposes, illustrates how far the European establishment has gone in abandoning its own values such as freedom of speech and respect for truth in order to appease a vocal minority ([20], p. 103). Thornton rejects charges of Islamophobia for his own beliefs, and maintains that many of the supposedly false prejudices about Islam are true. He maintains, for example, that Islam is responsible for the mistreatment of women and for intolerance towards other faiths ([20], p. 104). 
A core theme of the clash literature is that, rather than accommodate Muslim identity, Europeans and Westerners need to assert Western identity. Western eagerness to be politically correct results in efforts to accommodate Muslims at any cost. It gives Islam an advantage and adversely affects Western policy and the Western way of living. Whereas a focus on accommodation and mere integration contributes to an erosion of Western identity, a reemphasis on assimilation might help to correct a creeping tendency toward Muslim domination ([17], p. 60). Steyn frames the reassertion of a more exclusive Western identity as a matter of "Cultural Will": the Western majority culture needs to use the power it still has, and demonstrate that it is not weak.

\section{Women's Emancipation as a Focal Point}

In the clash literature, the status of Muslim women is construed both as a major defect in Muslim culture and as a potential wedge issue in the struggle between Islam and the West. Muslim women are presented as inexcusably oppressed, in a manner that faithfully reflects fixed and inflexible Islamic beliefs. Clash authors see these beliefs as the primary determining factor in a number of negative cultural dynamics, particularly abusive patriarchal authority, submissive and oppressed women, and the perpetuation of dangerous Muslim countercultures characterized by resentment and rapid population growth. They therefore aspire to amplify the voices of the most aggrieved and confrontational voices among Muslim or ex-Muslim women, who are represented as reliable interpreters of the overall Islamic experience.

Ayaan Hirsi Ali, often selected by other clash authors as the most authoritative voice on the oppression of Muslim women, represents the plight of women under Islam in starkly negative terms. Her portrait offers minimal nuance, and takes no note of variation in Muslim women's experiences in accordance with interpretive beliefs, geography, culture, or social class. "The will of little girls", she states, "is stifled by Islam".

$[B] y$ the time they menstruate they are rendered voiceless... they are reared to become submissive robots who serve in the house as cleaners and cooks... they are required to comply with their father's choice of mate and after the wedding their lives are devoted to the sexual pleasures of their husband and to a life of child-bearing... their education is often cut short when they are still young girls, and thus as women they are wholly unable to prepare their own children to become successful citizens in modern, Western societies. Their daughters repeat the same pattern ([16], p. xvii).

Nowhere in this account can one find acknowledgement of facts, which do not fit stereotypes, such as the dramatic growth of women's presence at university campuses (where they sometimes outnumber Muslim men) and in professions. Hirsi Ali's characterization is entirely consistent with Robert Spencer's hostile representation of Islam as a faith that in its immutable essence promotes gender inequality and violence towards women through genital mutilation, honour killings, stoning adulteresses, and holding women responsible for being raped ([13], p. 35). Neither author seeks to educate the reader about the non-universal character of such practices, or about Muslim voices who argue against them on an Islamic basis.

A reasonable argument can of course be made that traditional forms of Muslim patriarchy pose barriers to the advancement of Muslim women and to the successful integration of Muslim communities within Western societies. Hirsi Ali underscores this issue, albeit in a manner that 
equates the essence of Islam with specific historical practices and interpretations, and presents religion as an overwhelmingly negative factor:

I believe that the subjection of women within Islam is the biggest obstacle to the integration and progress of Muslim communities in the West. It is a subjection committed by the closest of kin in the most intimate place, the home, and it is sanctioned by the greatest figure in the imagination of Muslims: Allah himself ([16], p. 160).

As a formerly Muslim informant testifying to her own experience of oppression by family members in the name of religion, Hirsi Ali has produced a raw account that has a powerful impact on North American and European readers. Most Muslim feminists, however, would object strongly to her rhetorical equation of cultural pathology with the essence of a religion, articulated in a manner that seems intended to provoke outsiders to fight for the souls of Muslim women. Hirsi Ali argues that Western feminists should take on the plight of Muslim women and make it their own cause. There are three goals they must aspire to: ensuring that Muslims girls are free to complete their education; helping them to gain ownership over their own bodies and sexuality; and making sure that Muslim women have the opportunity to enter the workforce and stay in it, without restraints. Western feminists might also be at the forefront of a campaign to educate Muslim men on the importance of Muslim women's emancipation ([16], p. xix).

Although it may be an exaggeration to describe this approach to Islam and Muslims as "kill the Muslim, save the woman," most writers of Western-sourced clash literature regard fighting to liberate Muslim women as a critical front in the culture war between Islam and the West. They are profoundly impatient with "mainstream" voices of reform and moderation within Muslim communities, and give disproportionate attention to individuals who have written off Islamic reform movements and denounced Muslim culture categorically. The predominant tendency is to use the "status of women" issue as a key talking point in generalized critiques of Islam, with the goal of demonstrating the superiority of contemporary Western norms.

\section{Analysis}

Despite variations in emphasis and in the precise structure of arguments, the clash literature manifests a number of consistent tendencies that express the profound anxiety of many authors with respect to Islam, and that signal serious challenges for protagonists of intercultural dialogue and coexistence. First, the literature as a whole appears to be driven by deep-seated identity insecurity, not just in relation to an "intrusive" and seemingly monolithic Islam that is wholly "other," but also in relation to an idealized but now receding West that is being threatened from within by what the authors perceive a corrosive over-extension of their civilization's own ethos of critical reason. The remarkably broad generalizations and sharp dichotomies used in the literature are best understood not just as efforts to define an enemy, but also as attempts to recapture or define an "authentic" identity that has become internally contested. Thus, the arguments are not just about Islam, but also about the West. Second, in their critiques of Islam the clash authors rely heavily on extrapolation from past demographic data trends and from provocative incidents, with only limited consideration of complex causal factors that might provide a much richer context for understanding the phenomena in question. In this sense the literature appears to be more alarmist 
than analytical in nature and intent. Third, to the extent that the authors surface some genuinely problematic issues within Muslim cultures (immigrant and otherwise) and Islamic-Western relations, the insistence on polarization and "winning" manifested by their writings actively pushes against collaborative solutions predicated on dialogue and relational engagement.

\subsection{Arguments Rooted in Insecure Identity}

The arguments of clash authors manifest not just a profound fear of Islam, but also a powerful anxiety about threats to the future of "the West" that predates current controversies. In other words, the clash literature's call to arms against Islam and Muslim immigration is not simply a matter of Islamophobia, though certainly the discourse is permeated with deep distaste for all things that purport to be Islamic. Rather, is it also an expression of a longstanding debate about what the West is and should be. The fact that "the West" is so consistently represented in unproblematic, uncontested, essentialized terms - even as traitorous or suspect Western tendencies such as multiculturalism, Romanticism, or leftism are denounced-is itself a signal that, whatever else concerns the clash authors, they are fundamentally engaged in Western identity politics. In this sense, Islam enters the equation both as a substantive concern (there is no reason to doubt the genuineness of their fears) and as a foil, a useful "other" for defining what the "self" ought to be or not be. The clash authors' simplistic, essentialized, and almost entirely negative representations of Islam, therefore, serve the purpose of defining basic us/them distinctions that have an import which transcends intercultural relations.

In a very real sense, the clash authors' are deeply insecure about and uncomfortable with what the West concretely is and has become: hybrid, diverse, contested, culturally plural, and religiously diverse. This discomfort has been a long time in the making and is not new. The issue of Islam brings this discomfort to the surface, producing discourse that seeks to save what the authors fear they are losing, and to that end seeks to draw sharp dichotomies that reassert cultural boundaries and amplify debate about what it means to be "Western." The result is a discourse that privileges an idealized Western and European culture, juxtaposed with willfully undifferentiated representation of Islam as a static, unchangeable, and threatening adversary culture. Unreflective use of the term "Eurabia" manifests a sharply reductionistic tendency to equate Islam as a whole (a faith that spans continents and cultures) with Arabia and Arabia with salafist extremism.

The diversity within both of these "macro-identities" is purposefully downplayed and the relevant scholarly literature on this diversity is ignored. Europe is presented as the human Christian civilization that gave birth to skeptical humanism, and Islam as a universal, authoritarian, misogynist ideology without significant internal conflicts, schisms, and interpretive or legal debates. In seeking to galvanize Europeans against Islam and Americans against the European response to Islam, the authors seek to call Westerners back to fundamentals and undermine adversaries within their own context. Some readers may detect notes of envy in clash authors' characterizations of strong Muslim identities and doctrinal certitudes. Caldwell, for example, emphasizes the strength, confidence, and cohesion of Muslim culture, which in his view is an inherent threat to a more loosely anchored and "malleable" European culture ([19], p. 349). This imbalance, he believes, works to the detriment of Europeans, which are easily overwhelmed by strong immigrant cultures. 
To be sure, certain issues more salient for some clash authors than for others. For some, security and terrorism remain the preeminent issues, while, for others, a greater sense of motivation may arise from a sense of threats to individual freedom (including freedom from religion) or from a sense that traditional allegiance to Christianity or Judeo-Christian civilization has been betrayed by intellectual elites. In the issue of Islam, however, clash authors find common cause and a push to renegotiate among themselves a "pure" Western identity that is in many respects a new construction. In the process there is an opportunity and a need to affix blame to those who have let the "barbarians" through the gates.

Insofar as the clash literature is not only about "them" (Muslims) but also about "us" (people of the West and their existential discomfort with a changing world), the genre is arguably more symptomatic than diagnostic. Clash authors manifest great concern to draw lines and refuse identity negotiations with the deemed recalcitrant "other," and show very little interest in developing a nuanced, complex understanding of who that "other" actually is. Notably absent is the increasingly voluminous scholarly literature on Muslim negotiations with modernity, and only a few select scholars who deal with things Islamic are deemed trustworthy. Caldwell, for example, dismisses discussion of Muslim diversity "pleasing glibness," and like other clash authors characterizes Islam as a primordial religion impervious to outside influences and change. Thus, those who seek points of contact and shared values - let alone a reflection of the self in the otherare portrayed as outlandishly naïve.

\subsection{Reliance on Extrapolation, with Minimal Context}

In playing the role of Cassandra vis-à-vis a growing Muslim threat, clash authors repeatedly employ a style of reasoning based on simple extrapolation from past trends and generalization from specific, emotionally gripping incidents. The approach treats cultural and religious entities as static vectors rather than as dynamic communities that can change in response to new circumstances and relationships, and actively selects from the most disturbing of current events to give meaning to changing demographic realities.

Superficial use of demographic data is a clear liability of the clash literature, even when the figures themselves do speak to dramatic new tendencies in European societies. Immigration rates and differences in birthrates matter, and it appears certain that Islam will henceforth (albeit not for the first time in history, given centuries of Muslim presence in Spain and in Southeastern Europe) be a visible part of the European experience. The notion that this European experience will not or cannot have an impact on the way Muslims experience and express Islam, however, is as poorly founded as the notion that Muslim culture is immune to the sort of demographic transition that typically occurs in populations subsisting in industrial and post-industrial economic milieus. Anyone with close experience of young Muslim women pursuing university degrees, for example, is likely to discover that these women have professional and life aspirations that are highly similar to those of their non-Muslim counterparts. Simply put, "Islam" and "Muslims" are not categories that place human beings outside the larger continuum of human experience, and the notion that Muslims cannot adapt or will inevitably overwhelm others appears not just ill-founded but also prejudicial.

Another troubling tendency in the clash literature is its frequent exploitation of disturbing events for emotional impact. Clash authors over-select such events in their narratives and overgeneralize 
their representativeness, in ways that are clearly intended to arouse fear and anxiety in the reader. At the same time, they pass over incidents of violence or intimidation directed at Muslims in silence. While such selectivity and desire for emotional impact may be inevitable features of the journalistic style in which these books have been written, there is nonetheless a telling absence of humanizing portraits in the clash literature, despite the reality that "ordinary", non-threatening Muslims are much easier to encounter than extremists bent on violence or wedded to grandiose agendas. By over-selecting the negative, remaining silent about abuses committed against Muslims, and putting events and statistics in the most alarming context possible, clash authors seek to influence their audience in ways that are more alarmist than analytical.

This can be seen in Steyn's use of data from a poll conducted by the Times of London. Steyn conveys that seven percent of Muslims questioned agreed that suicide bombings of civilians could be justified in certain circumstances. Steyn interprets this to mean that significant numbers of Muslims are radical extremists. However, he does not explain how many people were polled, and to what extent those polled could represent the larger European Muslim population. He also ignores other data which reveals that the percentage of people who are willing to justify intentional bombing of civilians under "some circumstances" is roughly comparable in Western and Muslim contexts. By cherry-picking facts and ignoring those that do not fit the picture, any nation or religious group can be portrayed in a dark light.

A hallmark of quality analytical literature is that it is capable of confronting problematic issues and behaviour patterns in ways that probe beneath the surface, generating insights into circumstances and motivations in a way that does not obscure common humanity ore foreclose the possibility of constructive change. The clash literature falls short on these counts, by denigrating the search for drivers of extremism (an exercise that is deemed a form of capitulation), downplaying social class and social justice considerations, and ignoring the significance of prejudice, discrimination, and social exclusion. While there is no need to place all responsibility on host societies and governments or to hold immigrant communities blameless in instances where maladaptation is evident, the clash literature is deeply problematic in a host of ways: it ignores useful sociological insights, it vastly overgeneralizes about the other, it discounts the relevance of dialogue, and substitutes cultural reassertion for wide-ranging examination of policy options.

\subsection{Insistence on Polarization over Relational Engagement}

Ultimately, the clash literature identifies some genuine problems with Muslim integration in the West as well as in contemporary Muslim-majority cultures, but subverts critical reflection on ways in which "the West" is either implicated in these problems or capable of positive engagement with constructive forces within Muslim communities and cultures. The worldview of clash authors is not relational, and seeks no meaningful relationship with the Muslim other. The approach is profoundly non-dialogical and polarizing, with an emphasis is on winning rather than on transforming the conflict.

To an extent, the clash literature manifests continuity with Cold War narratives, albeit but with a new religio-cultural twist. Like post-9/11 Europe and North America, the Cold War world was one of polarization and ideological competition, within which complex world events were often viewed through lenses of East-West competition rather than in relation to complex local circumstances and 
realities. Then as now, the loyalty of Europe to the Western cause was suspect in the eyes of many Cold War protagonists, and the successors of these leading Western Cold War thinkers are now among the ranks of those seeking to understand the world in light of a new polarity.

If there is to be hope of transcending this polarity and creating a world in which "Islam" and "the West" are not mutually exclusive categories, relational engagement and dialogue are indispensable. It is not enough for Western pundits to speak about or even "to" Muslims, and dysfunctional to try to resurrect a past civilization based on mythical notions of purity. New forms of engagement are needed, and Western protagonists of such engagement need not embrace "relativism" to pursue it. Indeed, interlocutors that were truly confident in such putative Western values as reason, freedom, and equality would see no need to mythologize Western history (which, after all, has been full of both contradictions and progressive struggles to overcome them) or deny the existence of Muslims whose values overlap with those held by people in the West. Insofar as the clash literature manifests a certain lack of confidence in the West's greatest virtues, particularly in the domains of self-critique, dynamic reinvention of the self, and free-spirited of exploration, it offers few starting points for the needed cross-boundary engagement.

\section{Conclusions}

This essay has provided an overview and critique of a literature that is not often engaged by university-based scholars. There are reasons for this: most of the literature is not academic in nature, ignores relevant scholarship, and traffics in oversimplifications and polarizations that few scholars embrace. Nonetheless, precisely because this literature has wide circulation and plays a powerful role in constituting political discourse (as is evidenced by preemptive anti-sharia campaigns in the United States and the formation of anti-immigration parties in Europe), critical examination is needed.

While the term "clash literature" may seem novel or ambiguous, the term has been used here to refer to writings that articulate a number of consistent themes. First, these writings present a stark worldview in which Western liberalism is locked in a dangerous conflict with Islamic authoritarianism, with highly consequential developments currently unfolding in Europe. These events put the future of the West in question, despite its unassailable moral superiority in relation to Islam and non-Western cultures. Second, clash authors maintain that this struggle is rendered all the more difficult by what they judge to be an absence of genuinely moderate, progressive, and conciliatory tendencies within the global Muslim community. Islam demands conformity, they argue, and even "moderate" Muslims identify with some of the same grievances articulated by "extremists." Third, culture-clash thinkers place a very strong emphasis on threatening demographic trends associated with Muslim immigration; these trends have been made possible by (and accelerate) a loss of faith in the Judeo-Christian tradition, and make the demise of the West distinctly possible, to the extent that Europe may already be "lost." Fourth, clash authors seek to reinforce their arguments by claiming that resistance of Muslim immigrants to assimilation is a static and multi-generational condition. Muslims are unlike most other immigrants, and operate by values, which are alien to the contemporary Western tradition. Fifth, they maintain that the West has long been in denial with respect to these growing problems, on account of pervasive political correctness and the salience of multiculturalist sensibilities. Simply put, the West is in in crisis 
because of the disloyalty of its own intellectuals. Those responsible for economically based decisions to permit large-scale immigration, to satisfy demands of industry for guest workers and cheap labour, are not targeted with comparable accusations. Finally, clash authors propose that women's emancipation is one of the most fundamental wedge issues between Islam and the West, and needs to receive a strong focus from those seeking to stave off a Muslim takeover of Europe and push for victory in the protracted cultural war between civilizations.

While critiques of these sweeping, pessimistic assumptions are not difficult to identify, this article has sought to draw particular attention to three crucial issues raised by the clash literature. First, I have argued that, while these writings are intensely Islamophobic and purvey hostile stereotypes, they also reveal a great deal of insecurity with respect to Western identity. The literature's deeply problematic essentializations and generalizations warrant strong criticism, but there is also a need for awareness that the popular success of this literature stems not just from prejudice and lack of knowledge but also from deep-seated anxiety and insecurity. Old visions of what Europe and "the West" should be clearly to not fit the present reality, and there is a vacuum of compelling visions for how these identity structures might evolve in the future. The clash literature seeks to fill this vacuum with disturbing, reactionary visions that conveniently stigmatize a particular identity group.

The second and third lines of critique relate to the types of argument used and to the authors' proclivity for polarizing relationships that might possibly be bridged by other means. Clash books thrive on pessimistic extrapolation of demographic trends without a deep analytical investigation of underlying factors, and rush to conclusions about entire population groups based on specific cases of delinquency and violence. Their thesis that Muslims are difficult if not impossible to assimilate closely mirrors accusations directed against Catholic immigrants to the United States during the late nineteenth and early twentieth centuries. This pattern provides cause for reflection. Polarization and sharpening social conflict appears to be a primary goal of the genre, which actively dismisses dialogue and the value of relational engagement.

The clash literature demands a response-preferably a response that is not just a reaction or an application of pejorative labels to the authors, most of whom are doubtlessly sincere in their fear of Muslims, even when capitalizing on popular moods and anxieties for commercial gain. What is needed is a response that makes the complex nature of Islam-West relations more easily intelligible, and that liberates creative imagination by telling new stories. Scholars as well as journalists need to find ways to give voice to people who thrive at the intersection of cultures, who are not afraid, who honour the past but do not cling to it, and who are willing to learn and expand their sense of identity and belonging through encounters with otherness. A reaction to the clash literature that merely stigmatizes the clash theorists is a reaction that addresses symptoms but not the deeper problems. To give substance to ideas of dialogue and coexistence, authors need to dispense with simplistic dichotomies and dualisms, and with efforts to make fortresses out of Europe, North America, or any other cultural region. A scholarship that is itself dialogical and engaged might offer a stronger remedy, by surfacing latent visions, articulating "unstoried" experiences, and demonstrating that the points of intersection among cultures are sites not just of friction, but also of mutual learning, shared discovery, and common humanity. 


\section{Conflicts of Interest}

The author declares no conflict of interest.

\section{References}

1. Said, Edward. Orientalism. New York: Vintage Books, 1979.

2. Esposito, John, and Kalin, Ibrahim, eds. Islamophobia: The Challenge of Pluralism in the 21st Century. New York: Oxford University Press, 2011.

3. Lean, Nathan. The Islamophobia Industry: How the Far Right Manufactures Fear of Muslims. London: Pluto Books, 2012.

4. Sheehi, Stephen. Islamophobia: The Ideological Campaign against Muslims. Atlanta, GA: Clarity Press, 2011.

5. Lockman, Zachary. Contending Visions of the Middle East: The History and Politics of Orientalism. Cambridge: Cambridge University Press, 2009.

6. Saunders, Doug. The Myth of the Muslim Tide: Do Immigrants Threaten the West? Toronto: Knopf Canada Publications/Random House of Canada Publishers, 2012.

7. Keen, Sam. Faces of the Enemy: Reflections of the Hostile Imagination. San Francisco: Harper \& Row, 1986.

8. Montville, Joseph. "The Healing Function of Political Conflict Resolution." In Conflict Resolution Theory and Practice: Integration and Application. Edited by Dennis J.D. Sandole and Hugo van der Merwe. New York: Manchester University Press, 1993, pp. 112-27.

9. Moses, Rafael. "On Dehumanizing the Enemy." In The Psychodynamics of International Relationships: Volume I: Concepts and Theories. Edited By Vamik D. Volkan, Demetrios A. Julius and Joseph V. Montville. Lexington, CT: Lexington Books, 1990, pp. 111-18.

10. Nomani, Asra. Standing Alone in Mecca: An American Woman's Struggle for the Soul of Islam. San Francisco and New York: HarperSanFrancisco, 2005.

11. Sharify-Funk, Meena. Controversies, Clichés, and Conversations: Islam, Muslim Women, and the Negotiation of Identity in Contemporary North America. Forthcoming.

12. Safi, Omid. "Not conducive to the public good: American islamophobes barred from the UK." Religions New Service, 26 June 2013. http://omidsafi.religionnews.com/2013/06/26/notconducive.

13. Spencer, Robert. Religion of Peace?: Why Christianity Is and Islam Isn't. Washington, DC: Regnery Publishing Inc., 2007.

14. Spencer, Robert. "About Robert Spencer." Available online: http://www.jihadwatch.org/about-robert-spencer.html (accessed on 6 February 2013).

15. Bawer, Bruce. Surrender: Appeasing Islam, Sacrificing Freedom. New York: Doubleday Publishers, 2009.

16. Hirsi Ali, Ayaan. Nomad: From Islam to America. New York: Simon \& Schuster Publishers, 2010.

17. Steyn, Mark. America Alone: The End of the World as We Know It. Washington, DC: Regnery Publishing Inc., 2008. 
18. Warraq, Ibn. Why I am Not a Muslim. New York: Prometheus Books/Random House Inc., 2010.

19. Caldwell, Christopher. Reflections on the Revolution in Europe: Immigration, Islam, and the West. New York: Doubleday Publishers, 2009.

20. Thornton, Bruce. Decline and Fall: Europe's Slow-Motion Suicide. New York: Encounter Books, 2007.

21. Laqueur, Walter. The Last Days of Europe: Epitaph for an Old Continent. New York: Thomas Dunne Books/St. Martin's Press, 2007.

22. Wagner, William. How Islam Plans to Change the World. Grand Rapids, MI: Kregel Publishers, 2008.

23. "Kregel Publications." Kregel Publications. Available online: http://www.kregel.com/ME2/ Default.asp.authors (accessed on 10 February 2013).

24. Kepel, Gilles. The War for Muslim Minds: Islam and the West. Cambridge, MA: Belknap Press of Harvard University Press, 2004. 
MDPI AG

Klybeckstrasse 64

4057 Basel, Switzerland

Tel. +41616837734

Fax +41613028918

http://www.mdpi.com/

Religions Editorial Office

E-mail: religions@mdpi.com

http://www.mdpi.com/journal/religions 
ㅁ:

154 ISBN 978-3-906980-60-7

教教 www.mdpi.com 